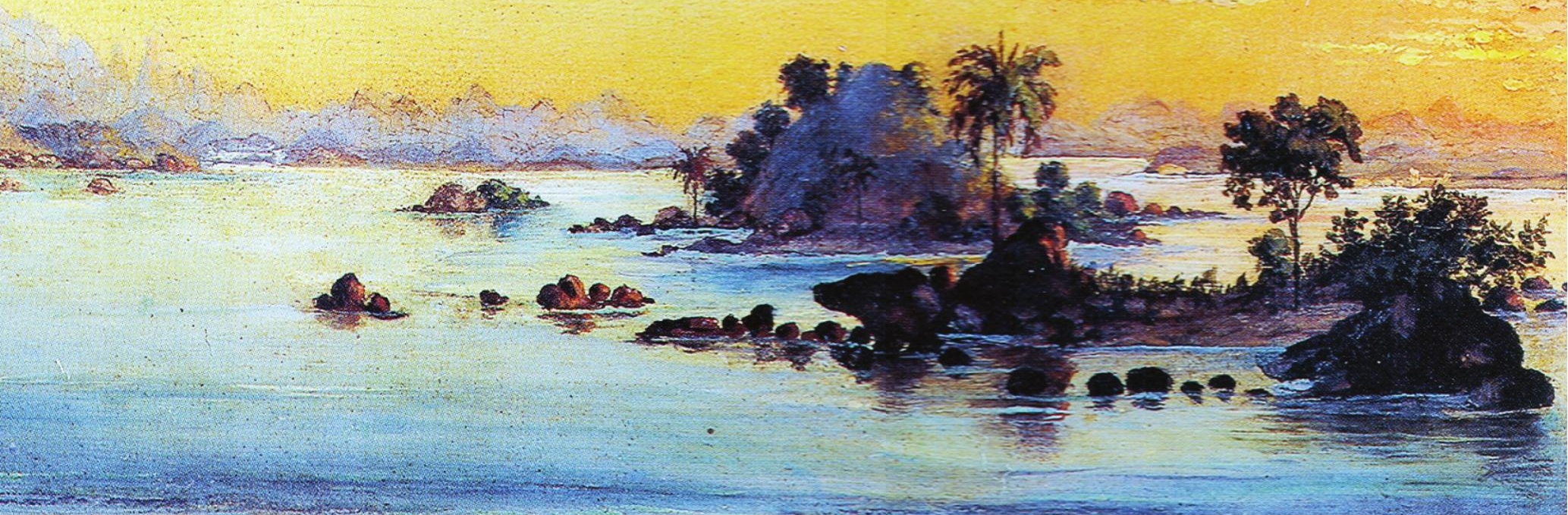


História

da Historiografia issn 1983-9928 


\section{Conselho Executivo}

Alejandro Eujanian (UNR . Rosário . Argentina)

Arthur Lima de Àvila (UFRGS . Porto Alegre . RS. Brasil)

Helena Mollo (UFOP. Mariana . MG . Brasil)

Fábio Franzini (UNIFESP . Guarulhos . SP . Brasil)

\section{Consellho Editorial}

Arthur Alfaix Assis (UnB . Brasília . DF . Brasil)

Claudia Beltrão (UNIRIO . Rio de Janeiro . RJ . Brasil)

Durval Muniz de Albuquerque (UFRN . Natal . RN . Brasil)

Fabio Wasserman (UBA. Buenos Aires . Argentina)

Fernando Nicolazzi (UFRGS . Porto Alegre . RS . Brasil)

Helena Mollo (UFOP . Mariana . MG . Brasil)

Julio Bentivoglio (UFES . Vitória . ES . Brasil)

Lucia Maria Paschoal Guimarães (UERJ . Rio de Janeiro . RJ . Brasil)

Pedro Meira Monteiro (Princeton University . Princeton . Estados Unidos)

Pedro Spinola Pereira Caldas (UNIRIO . Rio de Janeiro . RJ . Brasil)

Raquel Glezer (USP . São Paulo . SP . Brasil)

Rebeca Gontijo (UFRRJ . Seropédica . RJ . Brasil)

Ricardo Salles (UNIRIO . Rio de Janeiro . RJ . Brasil)

Rodrigo Turin (UNIRIO . Rio de Janeiro . RJ . Brasil)

Sérgio da Mata (UFOP . Mariana . MG . Brasil)

Temístocles Cezar (UFRGS . Porto Alegre . RS . Brasil)

Tiago C. P. dos Reis Miranda (Universidade de Évora . Évora . Portugal)

Valdei Lopes de Araujo (UFOP . Mariana . MG . Brasil)

\section{Consellho Consultivo}

Astor Diehl (UPF . Passo Fundo . RS . Brasil)

Carlos Fico (UFRJ . Rio de Janeiro . RJ . Brasil)

Carlos Oiti (UFG . Goiás . GO . Brasil)

Cássio Fernandes (UNIFESP . Guarulhos . SP . Brasil)

Chris Lorenz (VU University Amsterdam . Amsterdã . Holanda)

Denis Bernardes - in memoriam (UFPE . Recife . PE . Brasil)

Edgar De Decca (UNICAMP . Campinas . SP . Brasil)

Eliana Dutra (UFMG . Belo Horizonte . MG . Brasil)

Estevão de Rezende Martins (UnB . Brasília . DF . Brasil)

Ewa Domanska (Adam Mickiewicz University . Poznañ . Polônia)

Fábio Franzini (UNIFESP) . Guarulhos . SP . Brasil)

Fernando Catroga (Universidade de Coimbra . Coimbra . Portugal)

Francisco Murari Pires (USP . São Paulo . SP . Brasil)

François Hartog (EHESS . Paris . França)

Frederico de Castro Neves (UFC . Fortaleza . CE . Brasil)

Guillermo Zermeño Padilla (Colegio del México . Cidade do México . México)

Hans Ulrich Gumbrecht (Stanford University . Stanford . Estados Unidos)

Hayden White (Stanford University . Stanford . Estados Unidos)

Iris Kantor (USP . São Paulo . SP . Brasil)

José Carlos Reis (UFMG . Belo Horizonte . MG . Brasil)

Jörn Rüsen (KI/ UWH . Witten . Alemanha)

Jurandir Malerba (PUC-RS . Porto Alegre . RS . Brasil)

Keila Grinberg (UNIRIO . Rio de Janeiro . RJ . Brasil)

Luiz Costa Lima (PUC-Rio . Rio de Janeiro . RJ . Brasil)

Manoel Salgado Guimarães - in memoriam (UFRJ . Rio de Janeiro . RJ . Brasil)

Marco Morel (UERJ . Rio de Janeiro . RJ . Brasil)

Marlon Salomon (UFG . Goiânia . GO . Brasil)

Pascal Payen (Université de Toulouse II - Le Mirail . Toulouse . França)

Sanjay Seth (University of London . Londres . Reino Unido)

Sérgio Campos Matos (Universidade de Lisboa . Lisboa . Portugal)

Silvia Petersen (UFRGS . Porto Alegre . RS . Brasil)

\section{Secretario}

Rodrigo Machado (UFOP . Ouro Preto . MG . Brasil) 


\section{Ediitoração, revisão técnica e capa}

João Carlos Furlani (UFES . Vitória . ES . Brasil)

Rodrigo Machado (UFOP . Ouro Preto . MG . Brasil)

\section{Revisão de Língua Portuguesa}

Adriana Carina Camacho Álvarez "Lecttura traduções”

\section{Revisão de Língua Espanhola}

Adriana Carina Camacho Álvarez “Lecttura traduções”

\section{Revisão de Língua Inglesa}

Adriano Moraes Migliavacca “Lecttura traduções”

\section{Realização}

Sociedade Brasileira de Teoria e História da Historiografia (SBTHH)

Programa de Pós-Graduação em História da Universidade Estadual Federal do Rio de Janeiro (UNIRIO)

Programa de Pós-Graduação em História da Universidade Federal de Ouro Preto (UFOP)

\section{Apoio}

Conselho Nacional de Desenvolvimento Científico e Tecnológico (CNPq)

Coordenação de Aperfeiçoamento de Pessoal de Nível Superior (CAPES)

Fundação de Amparo à Pesquisa do Estado de Minas Gerais (FAPEMIG)

\section{Contato}

Rua do Seminário, $\mathrm{s} / \mathrm{n} \bullet$ Centro $\bullet$ Mariana $-\mathrm{MG} \bullet$ 35420-0oo • Brasil

www.historiadahistoriografia.com.br • historiadahistoriografia@hotmail.com • (31) 3557-9400

\section{Missão}

História da Historiografia publica artigos, resenhas, entrevistas, textos e documentos historiográficos de interesse para os campos da história da historiografia, teoria da história e áreas afins. Tem por missões divulgar textos de teoria da história e história da historiografia, e promover o intercâmbio de ideias e resultados de pesquisas entre investigadores dessas duas áreas correlatas. Num momento em que, no cenário brasileiro, o crescimento do número de periódicos científicos apenas espelha (se bem que de forma algo distorcida) a ampliação dos programas de pós-graduação, é consenso que o próximo passo a ser dado é o da verticalização e especialização do perfil das publicações. $H H$ foi fundada em 2008 exatamente a partir desse diagnóstico, e é hoje um periódico de referência para os especialistas das áreas de teoria da história e história da historiografia no mundo de língua portuguesa e espanhola. O periódico é uma publicação da Sociedade Brasileira de Teoria e História da Historiografia, do Programa de Pós-Graduação em História da Universidade Federal do Estado do Rio de Janeiro e do Programa de Pós-Graduação em História da Universidade Federal de Ouro Preto.

\section{Ficha Catalográifica}

História da Historiografia. Ouro Preto / Edufop, 2017, número 22, abril, 2017, 184 p.

Quadrimestral

ISSN 1983-9928

1. História - Periódicos

CDU 930(05) 


\section{EDITORIAL EDITORIAL}

\section{ARTIGOS ARTICLES}

A emergência dos sujeitos sociais na historiografia sobre a Guerra do Contestado

The emergence of social subjects in historiography on the Contestant War

Liz Andrea Dalfré

Representación e historiografía: miradas múltiples al pasado de la Isla de Cubagua (1892-2014)

Representation and historiography: multiple looks to the past of the Cubagua Island (1892-2014) Fidel Rodríguez Velásquez

Viera y Clavijo: Historiador ilustrado del Atlántico

Viera y Clavijo: Enlightenment Historian Atlantic

Juan Manuel Santana Pérez

A normatização disciplinar da historiografia universitária: Francisco Iglésias e a sua tese de Livre-Docência

The disciplinary norming of the university historiography: Francisco Iglésias and his Academic Thesis

\section{Alessandra Soares Santos}

As regras por detrás do jogo: a operação historiográfica de Michel de Certeau na obra de Wlamyra R. Albuquerque

The rules behind the game: Michel de Certeau's historiographical operation in Wlamyra R.

Albuquerque's work

\section{Rômulo Gonçalves Bittencourt}

Por uma teoria da modernidade em Poesia Ingênua e Sentimental

For a theory of modernity in On Naïve and Sentimental Poetry

\section{Géssica Góes Guimarães Gaio}

La convergencia de la historia y el psicoanálisis en Paul Ricoeur

Paul Ricoeur's convergence of history and psychoanalysis

\section{RESENHAS}

\section{REVIEW ESSAYS}

As propostas culturais, econômicas e políticas apresentadas nas primeiras Conferências Pan-Americanas

The cultural, economic and political proposals presented in the frst Pan-American Conferences DULCI, Tereza Maria Spyer. As Conferências Pan-Americanas (1889 a 1928): Identidades, União 


\section{TEXTO E DOCUMENTO HISTORIOGRÁFCO HISTORIOGRAPHICAL TEXT AND DOCUMENT}

A nostalgia como problema metahistórico: uma introdução

Nostalgia as a meta-historical problem: an interpretation

André de Lemos Freixo

138

Marcelo Santos de Abreu

Sérgio da Mata

A felicidade evadida. Uma interpretação da nostalgia

Happines evaded. An interpretation of nostalgia

Arnold Gehlen

Mal-estar na nostalgia

Nostalgia and its discontents

Svetlana Boym

153

\section{EM PAUTA}

ON SCHEDULE

Breves considerações sobre "Os lugares dos historiadores e da história na sociedade brasileira" Brief considerations on "Places of historians and history in Brazil"

\section{PARECERISTAS DESTE NÚMERO REVIEWERS OF THIS ISSUE}




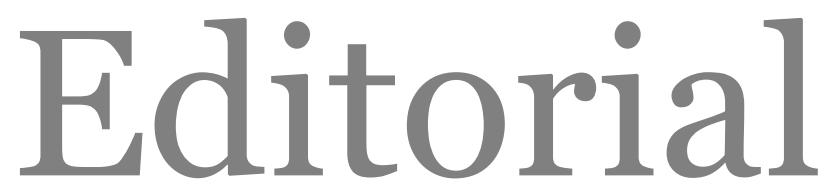

editorial 
Apesar do presente contexto de dificuldades colocado à produção científica brasileira, causadas pelos diversoscortes definanciamentoà aesquisa capitaneados pela atual administração federal e pela convulsão política generalizada no país, chegamos a mais um número da História da Historiografia. Nesta nova edição, a revista vê consolidada sua vocação internacionalista, trazendo três artigos de pesquisadores estrangeiros, e pluritemática, já que os textos que a compõem abarcam assuntos bastantes diversos, que vão desde a relação entre teoria da história e outras áreas do conhecimento até investigações sobre sujeitos e objetos específicos da história da historiografia brasileira e internacional.

No que tange às problemáticas da história e do funcionamento da disciplina, temos o artigo de Alessandra Santos sobre a tese de livre-docência de Francisco Iglesias, referência incontornável na história da historiografia brasileira. Do mesmo modo, Rômulo Gonçalves Bittencourt nos traz um instigante texto sobre a operação historiográfica nos trabalhos de Wlamyra Albuquerque, a partir, evidentemente, das teorizações primeiramente propostas por Michel de Certeau. Finalmente, ainda no que se refere aos percursos mais amplos da historiografia brasileira, Liz Andréa Dalfré nos apresenta uma investigação sobre a emergência dos sujeitos sociais na produção sobre a Guerra do Contestado, buscando compreender como historiadores e historiadoras diferentes entenderam a participação dos grupos sociais envolvidos no conflito.

Isto não é tudo, obviamente. O atual número traz ainda um texto de Géssica Guimarães Gaio sobre a experiência temporal moderna a partir das ponderações estéticas de Friedrich Schiller em sua "Poesia Ingênua e Sentimental". Como já foi dito, temos, ainda, três artigos de pesquisadores estrangeiros. Esteban Lythgoe discute, em sua contribuição, a convergência da história e da psicanálise na obra de Paul Ricouer, tendo como ponto de partida aquilo que ele chamou de "virada psicanalítica" na monumental obra do filósofo francês. Fidel Rodriguez e Juan Manuel Santana Perez, em seus textos, nos apresentam análises sobre as representações do passado da ilha venezualena de Cubagua entre 1892 e 2014 e da produção do historiador canário Viera y Clavijo, respectivamente.

Com pretensão de ampliar o debate historiográfico nacional, a revista apresenta às leitoras e leitores a resposta de Caroline Silveira Bauer ao texto de Rodrigo Sá Motta publicado na edição anterior, em que Bauer reflete sobre as funções dos historiadores e historiadoras diante não só do passado autoritário do país, especialmente da ditadura civil-militar, mas também das demandas colocadas por seus presentes. Em sua contribuição, Bauer nos lembra, assim, do aspecto inerentemente político, ainda que muitas vezes reprimido, da disciplina histórica.

Nesta edição temos, ainda, a resenha de Paulo Alves Pereira Jr. sobre a obra recente de Tereza Maria Spyer Dulci sobre as conferências pan-americanas realizadas entre 1889 e 1928.

Finalmente, fechando o número, André Freixo, Sérgio da Mata e Marcel Abreu nos brindam com a tradução de dois textos seminais sobre o problema da nostalgia, "A felicidade evadida", de Arnold Gehlen, e "A nostalgia e seus desgostos", de Svetlana Boyn, além de uma breve introdução sobre estes trabalhos. 
O corpo editorial da revista deseja, assim, ao público uma ótima leitura, com a esperança de que as barreiras colocadas à ciência em terras brasileiras sejam contornadas e que pesquisas e publicações voltem a ter a atenção financeira que merecem. Tempos mais alvissareiros virão.

8 
Artigos 


\title{
A emergência dos sujeitos sociais na historiografia sobre a Guerra do Contestado
}

\section{The emergence of social subjects in historiography on the Contestant War}

\author{
Liz Andrea Dalfré \\ liz_dalfre@yahoo.com.br \\ Doutora em História \\ Universidade Tuiuti do Paraná \\ Rua Emiliano Perneta, 195, apto 124, bloco B - Centro \\ 80010-050 - Curitiba - Paraná \\ Brasil
}

\begin{abstract}
Resumo
O objetivo desta reflexão é analisar o percurso historiográfico sobre o Movimento do Contestado e demonstrar como este conflito foi pensado, principalmente academicamente, ao longo dos séculos XX e XXI. Interessa verificar como os estudiosos do tema entenderam a participação dos atores sociais que se reuniram nas Cidades Santas, opondo resistência ao exército e aos governantes republicanos entre os anos de 1912 e 1916. Inicialmente foram resgatadas as primeiras narrativas sobre a guerra, com o propósito de verificar qual olhar sobre os rebeldes foi veiculado. Em seguida, foram analisadas obras paradigmáticas para a historiografia acadêmica sobre o tema, produzidas durante a segunda metade do século XX e primeira década do século XXI. Nestes estudos, foi observado a maneira como os pesquisadores compreenderam a ação dos grupos envolvidos no conflito e os caminhos adotados nesses estudos à medida que novas perspectivas teóricas foram incorporadas.
\end{abstract}

\section{Palavras-chave}

Ação; Brasil; Historiografia.

\begin{abstract}
The purpose of this reflection is to analyze the historiographical route on the Contested Movement and demonstrate how this conflict was thought, especially academically over the centuries XX and XXI. Interested to see how the theme of the scholars understood the participation of social actors who gathered in the Holy Cities, opposing resistance to the army and republican leaders in the years 1912 and 1916. Initially the first accounts of the war were rescued, with the purpose of check which look over the rebels was served. Then works were analyzed paradigmatic for academic historiography on the subject, produced during the second half of the twentieth century and the first decade of this century. In these studies, it was observed how researchers understand the action of the groups involved in the conflict and the ways in these studies as new theoretical perspectives have been incorporated.
\end{abstract}

Keywords

Action; Brazil; Historiography.

Recebido em: 16/6/2016

Aprovado em: 6/4/2017 
Impulsionados pela crise dos paradigmas estruturalistas e marxistas e pela emergência das perspectivas culturais, os estudos sobre os movimentos sociais ganharam novo impulso nas últimas décadas. Esse impulso esteve atrelado ao entendimento de que as identidades coletivas constituem processos dinâmicos em detrimento de análises que, anteriormente, concebiam as estruturas sociais como principal problema de pesquisa. Uma das questões que se sobressaem nessa renovação historiográfica é a problemática da constituição e atuação dos agentes sociais coletivos e individuais nos processos históricos analisados (MATTOS 2012, p. 95).

Essas transformações também ocorreram na historiografia sobre a Guerra do Contestado. O conflito que ocorreu no sul do Brasil entre os anos iniciais da República (1912-1916), foi transformado em objeto de análise imediatamente após sua conclusão e, desde então, têm sido amplamente estudado, sobretudo nos últimos anos, a partir de uma grande gama de perspectivas. ${ }^{1}$

O objetivo desta reflexão é explorar um percurso historiográfico e demonstrar como este conflito foi analisado, sobretudo academicamente, ao longo do século XX e no início do século XXI. Para além de buscar uma reflexão geral ou totalizadora sobre o evento, interessa especificamente verificar como alguns estudiosos do tema entenderam as ações dos atores sociais que se reuniram nas denominadas cidades santas para aguardar o retorno do seu líder espiritual, monge João Maria.

Para isso, será observado como os sujeitos sociais que atuaram na formação dos redutos rebeldes foram caracterizados e como suas ações foram interpretadas: a. nas primeiras narrativas sobre o evento; b. nas primeiras publicações de cunho acadêmico; c. nas reflexões acadêmicas das últimas duas décadas consideradas, pela autora desse texto, paradigmáticas em termos historiográficos no que se refere ao modo de entender a participação popular no evento.

\section{As primeiras publicações e a consolidação de um olhar sobre os rebeldes}

Tanto os textos produzidos pelos historiadores como as crônicas, os textos militares, o discurso jornalístico, o fílmico, entre outros, são construções narrativas que fornecem um olhar, uma visão, uma interpretação, uma pauta sobre esse conflito.

Por este motivo, antes de analisar os trabalhos acadêmicos, é interessante observar, ainda que de forma panorâmica, alguns trabalhos anteriores que em maior ou menor medida foram utilizados na historiografia posterior, ora de forma a serem reiterados, ora como ponto de ruptura e problematização.

As primeiras reflexões sobre a Guerra do Contestado ocorreram durante os acontecimentos da época, a partir do segundo semestre de 1912, quando tiveram início os ajuntamentos em torno do monge José Maria em Taquaruçu

\footnotetext{
${ }^{1}$ Em linhas gerais, a Guerra do Contestado se caracterizou como um conflito armado que envolveu moradores do interior de Santa Catarina e do Paraná, entre os quais lideranças políticas, fazendeiros e seus agregados, posseiros, além de personalidades políticas dos dois estados e do exército. O conflito se deu entre os anos de 1912 e 1916. Para uma definição mais completa da expressão, ver Dalfre (2014).
} 
(SC) e depois no Irani (PR). Desde esse primeiro momento, portanto, ocorreu uma produção de textos sobre esses acontecimentos. Essas primeiras narrativas surgiram nas páginas dos jornais, de Santa Catarina, do Paraná e de outros locais do Brasil. A imprensa escrita, do início do século $X X$, caracterizou-se por um posicionamento explicitamente formador de opinião, emitindo notícias carregadas de pareceres apaixonados e sensacionalistas.

Escritos no calor da hora, os jornais, sobretudo os regionais, evidenciavam embates cotidianos que se estendiam para além do palco do conflito. Em tom de indignação ou ironia, ao abordar tais acontecimentos a imprensa da época defendia posições políticas relacionadas ao litígio entre Paraná e Santa Catarina. ${ }^{2}$ As notícias eram alimentadas por essa disputa e pelos interesses vinculados a ela. Os editores dos jornais da época tentavam encontrar os responsáveis pela eclosão e extensão do conflito, buscavam caracterizar os grupos envolvidos além de indicar soluções possíveis.

Os jornais alimentavam uma imagem sobre os diferentes grupos envolvidos no conflito. Um exemplo pode ser observado no Diário da Tarde, um jornal paranaense da época. Enquanto o monge José Maria foi descrito no periódico como "guerreiro audacioso, fanático e monarquista" (DIÁRIO DA TARDE 1912, n. 4199, p. 4), João Gualberto, o militar que conduziu a tropa que lutou contra o monge no Irani, em 1912, foi descrito como "soldado que honra o Exército Nacional, jornalista vigoroso, engenheiro de vasta competência, patriota abnegado, amigo dedicadíssimo, indivíduo que cultua as mais altas virtudes 12 cívicas, chefe de família verdadeiramente modelar" (DIÁRIO DA TARDE 1912, n. 4196, p. 1). Já os rebeldes, figuraram como "turba fanática e crédula", "pobres analphabetos", "homens sem cultura e de uma credulidade inconsciente" (DIÁRIO DA TARDE 1912, n. 4182, p. 1; 4199, p. 1 e 4183, p. 1). Esses são exemplos de algumas oposições construídas por esse discurso que se colocou como civilizador e ilustrado identificando os sertanejos como desordeiros, ignorantes, fanáticos e analfabetos.

Um segundo conjunto de narrativas historiográficas foram os textos produzidos pelos militares que participaram do conflito e constituem uma das documentações mais utilizadas posteriormente pelos pesquisadores que se voltaram para esse tema. Muito do que conhecemos hoje como Movimento do Contestado foi edificado com base nesses relatos, que consolidaram uma determinada representação sobre o evento e seus participantes. Esses documentos, longe de serem neutros, evidenciam o posicionamento assumido pelo exército naquele momento, os motivos e interesses relativos à sua ação no front, além de serem porta-vozes importantes na glorificação do exército, na justificativa das derrotas que sofreram e na construção de uma imagem sobre os rebeldes.

\footnotetext{
2 Desde 1853, Paraná e Santa Catarina disputavam judicialmente a definição dos seus limites territoriais. Após a Proclamação da República e o princípio de autonomia dos estados da Federação, as discussões se tornaram ainda mais acirradas entre as instâncias de poder desses estados brasileiros, contando, em diversos momentos, com as opiniões de representantes políticos de outras regiões do país. Diversos foram os pareceres emitidos pelo poder federal, ora dando ganho de causa a um, ora a outro. O litígio somente foi resolvido em 1916, devido à pressão exercida pela Guerra do Contestado.
} 
Merecem destaque os textos de dois militares: Setembrino de Carvalho e Herculano Teixeira D'Assumpção. Os relatos que eles escreveram foram os mais significados, devido à importância atribuída a eles pela historiografia e à recorrência de sua utilização.

Fernando Setembrino de Carvalho foi comandante das forças do exército contra os redutos rebeldes e apresentou seu relatório de guerra em 1916, data na qual esse documento também foi publicado pela Imprensa Militar. Carvalho teceu considerações referentes aos acontecimentos cotidianos e às dificuldades pelas quais o exército passou, sofrendo com a ausência de verbas e de equipamentos adequados, mas também dá um parecer de cunho moral sobre tais eventos e seus participantes. Ele esteve na região do conflito entre 1914 e 1915, liderando o que chamou de luta "da civilisação contra a barbarie" (CARVALHO 1916, p. 254). A expressão enfatiza uma tentativa bem clara de definição de posições. "Cangaceiros", "quadrilheiros" e "bandoleiros" foram termos recorrentes no texto de Setembrino de Carvalho para definir os rebeldes.

Para este militar, pesou na constituição da população do Contestado, a presença de "perseguidos da justiça", que teriam chegado à região para trabalhar na construção da ferrovia São Paulo-Rio Grande, época na qual "os sertões foram se enchendo dos peiores malfeitores", segundo ele provenientes do Nordeste e do Rio de Janeiro (CARVALHO 1912, p. 3). Muitas dessas pessoas, conforme o autor, eram criminosos deportados, informação essa repetida diversas vezes pela historiografia posterior. Em um boletim publicado pelo Diário da Tarde, o militar questionou o fato de "cidadãos" terem abandonado seus lares "despresando o trabalho honesto e divorciando-se da civillisação" (DIÁRIO DA TARDE 1915, p. 1).

Outro militar que participou do evento registrando sua experiência na obra A Campanha do Contestado (1917) foi Herculano Teixeira D’Assumpção. Como primeiro-tenente do exército, participou do Movimento do Contestado sendo secretário do $58^{\circ}$ batalhão de caçadores e, em seguida, assistente da coluna que realizou o cerco aos rebeldes pelo lado sul. O seu texto apresenta um discurso permeado de reflexões e opiniões pessoais quanto a cultura e aos costumes dos habitantes do interior catarinense, além de relatar acontecimentos anteriores à sua presença no local. Como testemunha, considerava-se "leal e insuspeito", afirmando que estava sendo guiado "pela verdade dos factos" e "para dizer verdades taes, preciso appellar, com energia, para a serenidade imparcial de relator" (D'ASSUMPÇÃO 1917, p. I).

D'Assumpção compartilhou do mesmo pensamento daqueles que, à época, consideravam o fanatismo um fenômeno decorrente da falta de educação letrada entre os habitantes do interior do território brasileiro. Os acontecimentos que constituíram o conflito, na opinião deste militar, seriam "provenientes da cancerosa chaga do analphabetismo que se estende por todo o território nacional, talando os pontos mais longínquos, onde não chegam os bafejos saneadores da civilização hodierna" (D 'ASSUMPÇÃO 1917, p. I). A distância aparece aqui como um dos principais motivos do analfabetismo. Interessante notar ainda que os autores que atribuem o fanatismo à ausência de uma cultura letrada no meio sertanejo, não levaram em consideração que, neste período, a grande 
maioria dos moradores do litoral também não tinham acesso à educação formal. D'Assumpção, assim como muitos outros pensadores do período, negligenciou o número de analfabetos existentes na parte mais civilizada do Brasil.

D’Assumpção acreditava também que devido à ignorância, os moradores do interior deixavam-se facilmente dominar por pessoas alfabetizadas, ou seja, esses indivíduos não poderiam ser agentes de sua história. Por não possuírem uma educação letrada, se tornavam vulneráveis à ação de malfeitores espertos e letrados que porventura decidissem tirar proveito de sua ingenuidade e, por este motivo, eram facilmente manipuláveis. Essa era sua opinião em relação ao monge José Maria, por exemplo, responsável, segundo o militar, por ter incitado a população sertaneja a aderir ao "fanatismo demolidor". Para D'Assumpção, este era um homem inteligente e alfabetizado, que teria calculado os resultados que poderia obter dominando aquela população e preparando-a para a luta armada.

Por esses motivos, para D'Assumpção, a possibilidade de resolver os problemas que atingiam essa parte do país residia na educação de sua população. A alfabetização representava um dos poucos caminhos que davam acesso à atuação política e social consciente.

Definir o "typo sertanejo" também foi uma das direções seguidas por D’Assumpção em sua narrativa. Ele tentou descrever detalhadamente os hábitos, as atitudes e a forma de vida do habitante dos sertões sulinos. O autor caracterizou o morador do interior partindo da comparação e o modelo adotado 14 para tal foi o "tipo" ocidental, representado pela figura do imigrante alemão. Segundo D’Assumpção, os alemães constituíam uma "população ordeira, disciplinada, intelligente e summamente prestativa" exatamente o contrário da população cabocla, vinculada a miséria e a desorganização (D'ASSUMPÇÃO 1917, p. 199-200).

Nesta representação do tipo nacional, o narrador enfatizou questões relacionadas à ausência de higiene entre as populações sertanejas, noção que havia conquistado espaço nos planos de modernização das capitais brasileiras. Além desse aspecto, na sequência do relato o militar apontou questões relativas à agilidade do sertanejo nas matas, onde possuía "a ligeireza do jaguar", ao seu caráter de desconfiança, à importância do cumprimento que "é a primeira cousa que o viajante precisa saber fazer", ao costume de utilizar o verbo pôr no infinitivo (ponhar), à hospitalidade em relação às visitas, momento no qual o caboclo demonstrava ser "affavel", etc. (D'ASSUMPÇÃO 1917, p. 200-205). E concluiu:

É assim no sertão. Os seus homens mais rudes, dominados pela ignorância que gera superstições que muito concorrem para os seus continuados desvarios, esses homens são como os boidios: nem sempre provocam a lucta. Mas quando uma força superior sacode os seus instinctos perversos, dispertando-os com vigor, então elles evidenciam toda a sua maldade inconcebível, tornando-se inimigos terríveis, sanguinários, atilados e traiçoeiros (D'ASSUMPÇÃO 1917, p. 201). 
Portanto, sobre a docilidade, a falta de higiene, a importância que o caboclo atribuía à "prosa", prevalecia, na visão do militar, sua natureza perversa que frente a provocação de um inimigo ou simplesmente "aos pequenos actos que elle julga offensivos", vinha à tona. D'Assumpção não entendia que o sertanejo era protagonista de sua história, mas que ele respondia e interagia de acordo os estímulos vindos do meio.

Esse olhar, possibilitou a formação de uma representação maniqueísta em relação aos moradores do interior sulino. Ora comentando a respeito dos costumes mais cotidianos e "inofensivos", ora se referindo aos sertanejos como semibárbaros, sinistros e traiçoeiros, esse militar nos deixou uma das obras que mais foram utilizadas no estudo do Movimento e mostrou, a partir de sua narrativa, aspectos relacionados à imagem que as elites da época possuíam em relação àqueles que não compartilhavam de sua cultura e dos seus projetos.

Tanto Setembrino de Carvalho como Herculano D'Assumpção, utilizaram adjetivos classificando os rebeldes como inimigos da ordem e da lei, além de Ihe atribuírem o status de ignorantes e analfabetos. Esses relatos permearam as tentativas de constituição da nação brasileira bem como o desejo de modernizar o território nacional e, para isso, seria necessário incluir os bárbaros, tornandoos parte da pretendida civilização. Mas essa incorporação não seria conduzida pelos próprios sujeitos históricos, mas sim por aqueles que detinham o poder de identificar os males e as soluções possíveis. Os sertanejos eram resultado de alguma coisa: do analfabetismo e do pouco caso da política nacional, representados como portadores de uma patologia. Mas não eram considerados, por esses militares, agentes responsáveis e conscientes das transformações que eles acreditavam que deveriam ser operadas em suas vidas. Aos rebeldes não era conferida a possibilidade de discordar desse projeto civilizacional considerado a única via possível do progresso.

\section{Perspectivas acadêmicas a partir da década de 1950: os sociólogos}

Os primeiros trabalhos de cunho acadêmico sobre a Guerra do Contestado começaram a ser escritos a partir da década de 1950. Esses textos inauguraram uma nova forma de abordagem referente ao Movimento e aos personagens que nele estiveram envolvidos. Os sertanejos, a partir desses estudos, passaram a ser considerados de um ponto de vista mais antropológico e menos estereotipado. Aqui serão discutidas três obras que se tornaram referência para os estudos sobre o tema: O messianismo no Brasil e no mundo, de Maria Isaura Pereira de Queiroz (1965); Messianismo e conflito social, de Maurício Vinhas de Queiroz $(1977)^{3}$ e Os errantes do novo século, de Duglas Teixeira Monteiro (1974).

O primeiro desses trabalhos, da socióloga Maria Isaura Pereira de Queiroz, ${ }^{4}$ inaugura uma mudança em relação aos estudos sobre os movimentos sociais

\footnotetext{
${ }^{3}$ A primeira edição é de 1966.

${ }^{4}$ Além da publicação do livro Messianismo no Brasil e no mundo, Pereira de Queiroz defendeu em 1955, na École Pratique des Hautes Etudes, na França, sua tese intitulada La "Guerre Sainte" au Brésil: Le mouvement messianique du "Contestado".
} 
religiosos que até então, com frequência, localizavam os participantes destes conflitos nos limites da patologia social.

Sua análise, influenciada pelas ideias socioculturais do orientador, Roger Bastide, pauta-se na importância de encontrar definições científicas necessárias para enquadrar, em caracterizações comuns, diversos movimentos sociais localizados em tempos e locais distintos. Partindo de uma reflexão weberiana, na qual o messias é classificado como líder carismático, os movimentos messiânicos para Maria Isaura Pereira de Queiroz, teriam sempre a mesma forma, precedida pela figura do messias. No caso do Contestado, a autora atribuiu a denominação de messias aos monges.

Pereira de Queiroz indica um importante caminho ao criticar determinados aspectos presentes na definição do homem do interior existentes entre os pensadores do final do século XIX e início do XX, principalmente no que se refere à dicotomia litoral-sertão, diferenciação que simboliza a oposição progresso-atraso.

Considera ainda incorretas as afirmações de Euclides da Cunha e de Nina Rodrigues, quando estes indicaram que o estilo de vida do homem sertanejo se encontrava ameaçado pela invasão de uma cultura estranha, ocasionando a insurreição rebelde (QUEIROZ 1965, p. 343). Conforme as teses em vigor no início do século $X X$, a melhor forma de aniquilar esse tipo de reação seria levando o progresso aos moradores do interior, por meio da criação de escolas e da abertura de estradas, possibilitando a alfabetização e maior contato com os centros civilizados do país. Na perspectiva desses estudos, o messias seria o inimigo do progresso, chegando ao ponto de queimar objetos de luxo, definição essa decorrente da imagem de Antônio Conselheiro. Como principal argumento na defesa de seu ponto de vista, Pereira de Queiroz enfatiza que, ao contrário da afirmação desses cientistas sociais, muitos messias buscavam elevar o nível de vida dos seus adeptos, desenvolvendo o comércio, abrindo estradas, construindo casas, como no caso de Padre Cícero, por exemplo, que não só possuía uma educação letrada como também buscou transformar sua região em um grande centro econômico. Em relação ao grupo de Antônio Conselheiro, a socióloga afirma que queimavam objetos de luxo e não novidades, o que não contraria o progresso, mas sim, a riqueza (QUEIROZ 1965, p. 344-346).

Apesar de tais avanços e da noção de messianismo ter sido adotada por vários estudiosos na análise do Movimento do Contestado após a publicação da obra de Pereira de Queiroz, suas reflexões sobre o conflito sulino foram revisadas por diversos autores. Conforme Paulo Pinheiro Machado (2004, p. 26), se torna pouco útil a utilização da categoria "messianismo" da forma como emprega a socióloga. Para ela, a sociedade sertaneja do Contestado se encontrava em processo de anomia e o conflito possuía um caráter conservador, evidenciando uma crise estrutural. Na visão da autora, o Movimento do Contestado não foi nem subversivo, nem revolucionário, mas sim reformista. Segundo Machado, ao indicar como fator provocador do conflito o estado de anomia social, de perda de identidade como consequência de transformações sociais, culturais e econômicas, Pereira de Queiroz estaria nomeando de outra forma a patologia da população rebelde. Ao atribuir um estado de anomia social e de perda de identidade, a 
socióloga retira a legitimidade da crítica dos caboclos e desautoriza sua ação como uma atividade política consciente e vinculada a necessidades reais.

Em Messianismo e conflito social (1977), o sociólogo Maurício Vinhas de Queiroz. O autor percorreu um caminho que posteriormente foi assumido por diversos estudiosos do Contestado: a questão agrária. Embora a referência à terra não seja determinante em seu texto, já na introdução afirma que "pela primeira vez em nossa História as massas camponesas manifestaram a clara consciência da necessidade de garantir o seu 'direito de terras'" (QUEIROZ 1977, p. 13-14). Embora assuma um discurso bastante relativizante e enfatize as singularidades culturais dos rebeldes, ainda não rompe com alguns aspectos bastante característicos do pensamento social do início do século XX.

Devido ao anseio pela terra, por bem-estar e segurança, a população que vivia no território contestado teria sofrido uma crise estrutural, acumulada ao longo dos anos. Embora a ideia de consciência nos remeta ao entendimento de que o grupo possuía clareza em relação as experiências vivenciadas, o trabalho de Queiroz não reflete a ideia de que os participantes do conflito foram agentes de sua história, já que afirma, páginas depois, que eles possuam uma falsa consciência dos problemas existentes no interior de sua sociedade, problemas esses responsáveis pelo acúmulo de tensões (QUEIROZ 1977, p. 13, 14 e 249). Para o sociólogo, o messianismo caracteriza-se como uma revolta alienada que "confia na transfiguração supranaturalística do mundo", negando completamente a realidade compreendida como satisfação dos mínimos vitais.

O sociólogo acredita que os caboclos do Contestado "acordaram do sonho" quando perceberam as vicissitudes da guerra, passando por uma "desalienação" que os teria levado a formular reivindicações de teor secular. No final do Movimento, entretanto, com a dissolução da solidariedade comunal e o acirramento das tensões internas, o Movimento teria sofrido "uma espécie de regressão no sentido do autismo", se inserindo, portando, no terreno da patologia social (QUEIROZ 1977, p. 252-255).

Para Maurício Vinhas de Queiroz, a idealização monárquica pode ser considerada um sonho, um momento de alienação interrompido pelas agruras da guerra e pela percepção da morte, responsável por trazer os sertanejos de volta à realidade. Essa separação, entre real e irreal, corresponde a uma tradição intelectual racionalista que se consolidou em meados do século XIX, perpassando todo o século XX (BACZKO 1985, p. 297). O livro de Vinhas de Queiroz, publicado em 1966, conserva características oriundas dessa tradição de compreender a razão e a ciência em oposição aos sentimentos, às sensibilidades e às crenças populares. A ciência e a razão, noções apropriadas em seu extremo, tornaram possível o desprezo e o esquadrinhamento dos costumes e do modo de vida alheios ou estranhos, fator que "conjugava-se perfeitamente com o sonho colectivo de uma sociedade e de uma história finalmente transparentes para os homens que as constituem" (BACZKO 1985, p. 297).

De acordo com essa matriz de pensamento, a operação científica serviria como fio condutor para desvendar a história, desmistificar o que estava oculto, buscar a lógica para aquilo que não tinha explicação a partir de uma concepção 
racionalista do homem e da sociedade. Por outro lado, ao assumir esse viés, Vinha de Queiroz excluía a capacidade protagonista dos rebeldes em desenhar reinvindicações que eram reais.

Essas reflexões visam demonstrar que mesmo entre os estudos acadêmicos sobre o Movimento do Contestado, realizados a partir da década de 50, ainda permaneceram tentativas de inclusão do outro em um espaço caracterizado pela anormalidade. Os sertanejos continuaram sendo considerados diferentes, não somente pela sua singularidade cultural, mas também pelas características que os tornavam "autistas", portadores de uma patologia social e incapazes de proporem mudanças sociais legítimas.

Diversos pesquisadores, em trabalhos posteriores, questionaram esse posicionamento racionalista frente às crenças e ao imaginário dos homens comuns, priorizando aspectos fundamentais na concepção de mundo dos habitantes do interior do Brasil. À espera do messias e de São Sebastião com seus cavaleiros, a idealização monárquica e a crença na vitória, fizeram parte da realidade dos sertanejos tanto quanto a guerra, as mortes e as doenças, como poderá ser constatado adiante.

Na terceira obra a ser analisada, Errantes do novo século, o autor Duglas Teixeira Monteiro enfatiza que para alcançarmos um entendimento em relação ao conflito é necessário, antes de mais nada, compreendermos como os caboclos pensaram e construíram sua nova realidade. Sua reflexão é orientada pela sociologia da religião, por meio da qual intenciona

[...] analisar o comportamento social de uma comunidade humana que, enfrentando uma crise global, recolocou, dentro dos limites que the eram dados, os problemas fundamentais de sua existência enquanto grupo. Ao fazê-lo, elaborou um universo mítico, adotando as condutas ritualizadas correspondentes (MONTEIRO 1974, p. 10-11).

As expressões weberianas "desencantamento" e "reencantamento do mundo", tornaram-se conhecidas daqueles que se voltaram para a temática do Contestado, devido à obra deste autor. Conforme Monteiro, a ideia de desencantamento aplicado a esse contexto, se refere à ruptura da estrutura vigente entre os moradores da região e estaria vinculado à própria crise do coronelismo e à penetração das empresas capitalistas ocupando diversificados ramos de trabalho, o que teria ocasionado o rompimento entre o consenso e a coerção e teria levado ao conflito propriamente dito. Antes disso ocorrer, o autor acredita que existia uma estratificação das relações sociais, baseada em normas tradicionais onde as representações materiais e simbólicas caminhavam juntas e cuja unidade encontrava-se no fator religioso. "Sua estabilidade é mantida pela junção entre um consenso que encobre os aspectos coercitivos e uma coerção que garante a continuidade consensual" (MONTEIRO 1974, p. 13).

Essa crise das relações - conduziu-os, segundo Monteiro, a um reencantamento do mundo, propiciado a partir dos valores ameaçados por essa crise. Os consensos foram elaborados, deste momento em diante, enquanto a coerção foi sancionada por elementos mítico-religiosos. 
Assim como Monteiro, outros pesquisadores deste mesmo período, voltaram suas preocupações para os processos de luta camponesa que ocorreram no sul do país entre o final do século XIX e durante o século XX, sobretudo a partir de estudos monográficos voltados para contextos regionais ou por meio de sínteses direcionadas a explicações de ordem estrutural. ${ }^{5}$ Segundo Welch, na década de 1970, entidades como a Fundação Ford, apoiaram projetos de pesquisa no Nordeste que culminaram na publicação de trabalhos sobre o campesinato e os sindicatos rurais. Também datam desta época, diversos trabalhos acerca dos trabalhadores volantes, denominados boias-frias (WELCH 2006, p. 65).

Os estudos de Monteiro se inserem no contexto da organização de movimentos pela democratização do país e no recrudescimento da luta pela terra, que ocorreu ao longo das décadas de 1970 e 1980. Para Hebe Mattos (2012, p. 102), a partir da década de 1970 novas questões se impuseram para os historiadores, sobretudo no que concerne às temáticas ligadas aos movimentos sociais. Essas reflexões foram resultado da pressão exercida pela emergência de novos atores sociais impulsionados pelas manifestações de identidades coletivas como o movimento negro, o movimento feminista, entre outros.

Apontando para uma nova perspectiva historiográfica, Monteiro foi o primeiro pesquisador do Contestado a fazer considerações a respeito das análises que seguiram o caminho do determinismo do meio e da raça. Segundo o sociólogo, as explicações sobre o Contestado caracterizaram-se

Pelo emprego de explicações que recorrem a poderosos determinismos geográficos ou biológicos na análise dos "fanatismos" religiosos brasileiros. $\mathrm{Na}$ vigência dessa voga, falava-se nas condições da terra, no clima, na composição étnica das populações envolvidas. Ou então, de modo menos generalizador, na ocorrência de "loucuras" ou "delírios coletivos" (MONTEIRO 1974, p. 12).

A atribuição da ideia de loucura àqueles que "reencantaram" o mundo, para Monteiro, está relacionada à necessidade de classificar os rebeldes a partir da utilização de categorias opostas, como sertão e litoral, elementos fundamentais no pensamento social até a década de 1930 , muito recorrentes nos estudos sobre esse tipo de conflito.

Além de indicar as dificuldades relativas à utilização de conjuntos de termos opostos no estudo sobre a guerra, o sociólogo aponta algumas características presentes nessas abordagens, como o desconhecimento e a autenticidade atribuída aos habitantes do sertão, questão que ganhou importância nas narrativas que pensaram o Brasil, nas primeiras décadas do século XX.

Para o autor, o mundo material e religioso são os mesmos e os rebeldes que optaram por uma via mitologizante eram pessoas normais "ou não menos normais que seus adversários" (MONTEIRO 1974, p. 15). Quanto ao caráter contestatório do Movimento e ao protagonismo dos envolvidos no processo, para Monteiro (1974, p. 214), "a linguagem religiosa, não assume, desse modo, 
a característica de uma forma que encobre interesses e impulsos sociais de caráter terreno", mas sim, transfiguraram-se assumindo uma outra dimensão, que seria a religiosa.

Mesmo após a publicação das obras dos sociólogos apresentados, ainda persistiram análises onde o modo de vida do habitante do interior foi compreendido de forma estereotipada e preconceituosa, apesar de muitas vezes, os sociólogos serem citados na bibliografia. ${ }^{6}$ Se por um lado é possível observar uma superação de posições estigmatizantes quanto àqueles que moravam no interior e viveram nos redutos, por outro, diversos aspectos desse posicionamento continuaram presentes, marcando amplamente a alteridade, enfatizando e nomeando as diferenças, muitas vezes apresentadas com outra roupagem, mas demonstrando a permanência de uma necessidade de classificar o outro, indicando-Ihe adjetivos, nomeando seu lugar e suas atitudes e, sobretudo, destituindo a legitimidade de sua atuação como sujeito histórico.

\section{Olhares historiográficos: as últimas décadas do século XX $\mathrm{e} O$ início do século XXI}

Na segunda metade do século XX e início do XX, diversas obras foram escritas sobre o Movimento do Contestado, além daquelas produzidas pelos sociólogos já citados. Não nos deteremos em todos os trabalhos, mas somente nas reflexões que representaram um salto historiográfico na abordagem sobre a agência dos sertanejos envolvidos no conflito. Entretanto, para que esse

20 percurso fosse trilhado, vale lembrar que a partir dos anos 80 , surgiu um novo conjunto de pesquisas acerca dos movimentos sociais inspirados, de um lado, pelo processo de redemocratização que possibilitou a emergência de crítica mais abertas à estrutura oligárquica e, de outro, pelas mobilizações populares, sobretudo dos trabalhadores rurais, que irromperam a partir do final da década de 1970. Segundo Paulo Pinheiro Machado "esta luta fez reviver a memória e ressignificar a experiência dos sertanejos de várias lutas antigas, como Canudos, Porecatu, Tombras e Formoso, Ligas Camponesas e o movimento do Contestado" (MACHADO 2016, p. 23).

Neste contexto, foram produzidos trabalhos sobre a importância do movimento sindical entre o campesinato, sobre as Ligas Camponesas, referente a atuação do Partido Comunista no meio rural e vários estudos voltados para a compreensão do papel das lideranças nos movimentos sociais, com ênfase para o papel desempenhado por determinados sujeitos históricos. ${ }^{7}$

Ao longo dos anos 90 e no início do século XXI, essa produção se tornou ainda mais numerosa, com a inserção de fontes documentais e metodologias

\footnotetext{
${ }^{6}$ Um exemplo é o trabalho de Pereira (1966) ou ainda o trabalho de Facó (1978) (publicado originalmente em 1963). Este autor desconsidera os aspectos religiosos como elementos prioritários do Movimento reduzindo-os a um fundo de interesse material.

7 Algumas sínteses podem ser citadas como representativas do aumento do interesse pelos movimentos sociais, embora nem todas tratem do protagonismo do campesinato, como os trabalhos de Brasil de José de Souza Martins (Os camponeses e a política no Brasil, de 1981); de Aspásia de Alcântara Camargo (A questão agrária: crise de poder e reformas de base (1930-1964, publicado em 1981); e Leonilde Sérvolo de Medeiros (História dos movimentos sociais no campo, de 1989). Para maiores detalhes sobre essa historiografia ver: Welch (2006).
} 
que valorizaram a fala dos grupos denominados pela história social como "subalternos", como a história oral, por exemplo, amplamente utilizada para demonstrar a atuação política de trabalhadores rurais, peões, mulheres, entre outros sujeitos históricos. Houve uma crescente preocupação com a história "vista de baixo", com o empirismo e os processos históricos em detrimento das explicações estruturais. ${ }^{8}$

Nesta perspectiva, cabe enfatizar que somente a partir do final de década de 1990, é possível observar transformações significativas do ponto de vista historiográfico sobre o Contestado, entre as quais se destacam três elementos, que possibilitam concentrar esses trabalhos ente o final da década de 1990 aos dias atuais. Primeiramente, foi o momento a partir do qual historiadores de formação se dedicaram ao tema. Em segundo lugar, após esse momento, trabalhos acadêmicos sobre o tema passaram a ser pesquisados nas universidades, sobretudo do sudeste e sul do Brasil. E, finalmente, é possível identificar nesses trabalhos uma grande variedade temática nas problematizações e nas construções dos argumentos, cujas orientações teóricas seguem propostas, sobretudo, da Nova História francesa, da Micro História italiana e da História Social inglesa.

Se foi entre os anos de 1970 e 1980 que as temáticas ligadas aos movimentos sociais ganharam corpo, foi no final da década de 1990 que elas adquiririam nova roupagem, com análises centradas na perspectiva culturalista e foi na virada do XX para XXI, que ocorreu a renovação da vertente da história política, a emergência das trajetórias individuais e a valorização dos aspectos ligados a memória desses movimentos. As tensões oriundas da relação entre memória, história e movimentos sociais, além da pressão dos movimentos sociais sobre os historiadores, favoreceu o declínio das fronteiras entre o socioeconômico, o político e o cultural nas análises acadêmicas (MATTOS 2012, p. 105). Nesse contexto, a ideia de agência se tornou central e as ações, as subjetividades, os interesses, os desejos e as perspectivas dos sujeitos sociais envolvidos em diferentes manifestações, movimentos e conflitos, se transformaram em foco de problematizações e análises variadas.

Para este artigo, foram selecionados dois trabalhos considerados aqui muito significativos nos rumos adotados pela historiografia sobre o Movimento do Contestado no Brasil das últimas duas décadas. ${ }^{9}$

O primeiro deles, fruto de uma dissertação de mestrado, é o livro da historiadora Marcia Janete Espig, A presença da gesta carolíngia no Movimento do Contestado, publicado em 2002. ${ }^{10}$ Nesta pesquisa Espig (2002, p. 21-22) tem

\footnotetext{
${ }^{8}$ Exemplos dessas novas perspectivas podem ser encontradas para a região sul, por exemplo, por meio dos trabalhos sobre a Revolta de Porecatu, com destaque para as pesquisas de Ấngelo Priori, Osvaldo Heller da Silva e Verônica Karina Ipólito; sobre a Revolta de 1957 do Sudoeste do Paraná, com destaque para os trabalhos de Paulo José Koling, Silvia Maria Amâncio, Anita Izabel de Mello da Silva e Éverly Pegoraro.

9 A pesquisa de Todd Diacon, publicada em 1991 sob o título Millenarian Vision, Capitalist Reality - Brazil Contestado rebellion, 1912-1916, consiste em uma importante investigação na qual a Guerra do Contestado é analisada a partir da dimensão espiritual e da percepção dos seus participantes. O autor também apresentou um importante conjunto de fontes de época e de entrevistas realizadas na região. Esse trabalho não será analisado de forma pormenorizada neste artigo, pois o texto em questão nunca passou por um trabalho de tradução, o que dificulta seu alcance em termos acadêmicos, sobretudo para os cursos de graduação.

10 Espig defendeu sua dissertação de mestrado em história em 1998 na Universidade Federal do Rio Grande
} 
como objeto de estudo compreender "o como e o porquê" da aceitação da obra Carlos Magno e os Doze Pares de França no imaginário local dos participantes da guerra. À autora interessa perceber a presença dessa literatura "como uma forma de aproximação analítica dos aspectos que compunham o imaginário do grupo de rebeldes do Contestado" (ESPIG 2002, p. 65).

Em sua análise, Espig (2002, p. 65-68) enfatiza o "caráter de representação" presente no trabalho. Ela dialoga com autores como Bronislaw Baczko, do qual faz uso do conceito de imaginários sociais, de Roger Chartier e suas reflexões sobre representação e apropriação e de Pierre Bourdieu, sobretudo para compreender a relação entre a realidade estruturada as parcelas de indeterminação, fundamentais para a pluralidade e elasticidade das visões de mundo e respostas fornecidas pelos atores sociais analisados.

Ao se preocupar com o imaginário do grupo rebelde, por meio da apropriação que fizeram da literatura, a autora afirma que pretende "compreender melhor a subjetividade e a ação concreta daqueles agentes" (ESPIG 2002, p. 65). Para Espig (2002, p. 65), aspectos relacionados a forma como os sujeitos sociais em questão interpretaram o mundo são centrais. Ela enfatiza que manifestações subjetivas como as que ocorreram no Contestado, durante muito tempo, estiveram associadas a sonhos e ilusões ou foram entendidas como elementos menores que encobriam necessidades realmente objetivas, visão essa que se contrapõe às novas vertentes historiográficas que entendem os aspetos subjetivos "tais como crenças, mitos, ritos, representações, imaginários e visões de mundo [...] 22 como uma problemática legítima no campo dos estudos históricos".

A segunda obra entendida como importante marco das duas últimas décadas para a historiografia sobre o Contestado é de autoria do historiador Paulo Pinheiro Machado. ${ }^{11}$ Originalmente concebido como tese, o livro Lideranças do Contestado: a formação e a atuação das chefias caboclas (1912-1916) foi publicado em 2004. Neste texto, Machado (2004, p. 23) tem como questão central "fazer um levantamento e a análise das origens sociais e da formação e atuação política das lideranças sertanejas na Guerra do Contestado".

Como o próprio título do trabalho infere, sua preocupação se concentra em destacar o papel dos comandantes caboclos que atuaram como líderes à frente dos redutos santos no período da guerra, sobretudo entre 1914 e 1916, momento no qual se destacaram as lideranças com evidente preocupação estratégica e política. Neste trabalho, fica evidente a importância atribuída a ideia de agência. Sobre essa perspectiva, Machado (2004, p. 26) destaca

[...] os sertanejos acabaram demonstrando, tanto por discursos como por atos, que desenvolveram uma nítida consciência das condições sociais e políticas da sua marginalização, de que se tratava de uma guerra entre ricos e pobres, que lutavam contra o governo, que defendia o interesse dos endinheirados, dos "coronéis" e dos estrangeiros. 
A partir de uma orientação teórica fornecida por autores de tendência marxista, sobretudo vinculados à Nova Esquerda inglesa, o autor estabelece um diálogo crítico acerca das reflexões historiográficas voltadas aos movimentos sociais em sociedades pré-industriais, como os trabalhos desenvolvidos por George Rudé, Eric Hobsbawm e Edward P. Thompson. Esses autores forneceram importantes contribuições para o trabalho de Machado ao apontarem encaminhamentos e reflexões relativos ao tratamento dado às fontes, sobretudo aquelas ditas "tradicionais" (Georges Rudé); ao destacarem as resistências materiais e simbólicas de trabalhadores que se opuseram à inovações impostas pela modernização (E. P. Thompson); e ao indicarem perspectivas para a reflexão em torno das ideias de banditismo social e de movimentos pré-políticos (Eric Hobsbawm).

Machado não adota essas noções de maneira absoluta, ao contrário, ele avalia os limites de algumas dessas análises e. entende como problemático, por exemplo, o fato de alguns desses autores, como Hobsbawm, pensar o campesinato de forma limitada, entendendo-o como um grupo em vias de extinção. Segundo Machado, que utiliza Raymond Williams para embasar seu ponto de vista, esse posicionamento deriva de um tipo de leitura marxista preconceituosa em relação ao mundo rural.

Machado (2004, p. 33) dialoga ainda com o antropólogo Eric Wolf, que o auxilia a pensar na estrutura organizacional dos rebeldes e com o historiador italiano Giovanni Levi. Este último, fornece subsídios para o autor entender a capacidade criadora dos sertanejos rebelados e a buscar, mais do que caracterizações reducionistas e tipologias generalizadoras, as origens, a expansão e os limites da atuação dessas pessoas na guerra.

O historiador acredita que nem mesmo para efeito didático podemos separar a questão religiosa da crítico-social e indica dois fatores como pontos fundamentais relacionados à questão agrária que repercutiu no Movimento do Contestado: a legislação republicana e a chegada da empresa Brasil Railway Company, responsável pela construção da estrada de ferro que ligava São Paulo ao Rio Grande do Sul. Sua orientação teórica aponta para a perspectiva que claramente defende. O conflito do Contestado, em sua opinião, constituí um "episódio importante na história da luta de classes no Brasil" (MACHADO, 2004, p. 35).

Além dos trabalhos citados, que estão publicados, existe uma série de teses, dissertações e artigos significativos do ponto de vista analítico e de renovação historiográfica. Um exemplo é a tese de Márcia Janete Espig. Intitulada Personagens do Contestado: os turmeiros da Estrada de ferro São Paulo-Rio Grande (1908-1915) defendida em 2008. Norteada por questões propostas pela micro história, a historiadora fez um levantamento minucioso e microscópico sobre os trabalhadores que atuaram na construção da linha sul da EFSPRG da Brazil Railway Company. Espig procurou evidenciar a origem e as experiências desses trabalhadores e se tiveram ou não envolvimento na Guerra do Contestado, que ocorreu alguns anos após o término da construção da ferrovia. 
O trabalho de doutorado e de mestrado de Rogério Rosa Rodrigues também apresenta uma perspectiva inovadora nas reflexões acerca do conflito do Contestado. Rodrigues levanta questões importantes no que concerne ao modo de pensar e aos caminhos seguidos pelo exército durante os combates entre caboclos e forças militares, relacionando essas reflexões com as representações erigidas pelos próprios militares ao narrarem o conflito (RODRIGUES 2001; 2008). ${ }^{12}$

O autor ressalta, em suas pesquisas, a mobilização dos símbolos empregados pelos militares e as tentativas destes de justificar a ação no front, tanto para a sociedade civil quanto para os próprios militares envolvidos na guerra. Nesse sentido, o autor aponta para o esforço militar realizado durante o conflito no sentido de mobilizar equipamentos bélicos modernos e construir uma imagem positiva do exército.

Rodrigues também identifica representações recorrentes, envolvendo concepções maniqueístas da sociedade brasileira e aponta para o fato das narrativas militares estarem inseridas no campo literário-político do início da República, marcando, da mesma forma como os escritos intelectuais, a desilusão frente ao novo regime.

Quanto à questão da agência na guerra, o autor traz uma abordagem que considero inovadora por demonstrar as fragilidades e dificuldades vivenciadas pelos soldados no palco do conflito, bem como às dúvidas e incertezas que marcaram a ação militar (RODRIGUES 2001, p. 29-35). Perceber que as 24 dificuldades, dúvidas, angústias, deserções, estiveram presentes não somente do lado dos rebeldes, mas também dos repressores, sobretudo àqueles que estavam acampados nas serras catarinenses, é importante à medida que possibilita a desconstrução da ideia da instituição militar como uma entidade homogênea, controlada e totalmente disciplinada. $O$ autor identifica ainda momentos de insubordinação, delitos e crimes realizados pelos soldados, o que coloca em xeque "o ideal profissional e moderno" do exército nas primeiras décadas republicanas (RODRIGUES 2008, p. 22).

Os autores apresentados neste último item também são figuras centrais nos debates sobre o tema bem como na organização de eventos, livros e na orientação de pesquisas acadêmicas, que apontam para uma grande diversidade de perspectivas em termos teóricos e metodológicos e quanto às problematizações propostas.

\section{Considerações finais}

As diversas versões ou representações sobre o que se convencionou chamar Guerra do Contestado, fazem parte da sua história. O Contestado somente existe como fato histórico-social porque foi eleito como tal, porque sociólogos,

\footnotetext{
${ }_{12}$ A dissertação de mestrado e a tese de doutorado de Rodrigues tratam do tema dos militares e sua participação na Guerra do Contestado. As duas pesquisas representam um esforço contínuo do historiador no sentido de compreender, de forma aprofundada, a atuação militar, não somente durante o período da guerra (1912-1916), mas também posteriormente, quando os militares elaboram explicações sobre o conflito, seus participantes e o local onde eles viviam, constituindo dessa forma, o primeiro conjunto memorialístico sobre a guerra.
} 
religiosos, políticos, artistas, jornalistas, historiadores e cineastas pensaram sobre ele. Cada um desses grupos ou pessoas construiu uma imagem sobre esse evento, vinculada a visões de mundo e questões teóricas específicas, próprias de cada tempo e lugar. Conhecer os caminhos seguidos por essas narrativas significa compreender, principalmente, a forma como se construiu uma memória coletiva sobre o conflito e seus participantes.

No caso do Movimento do Contestado foi possível perceber, nessa breve reflexão sobre sua historiografia, alguns percursos, principalmente acadêmicos, e alguns pontos paradigmáticos das pesquisas. Nesses estudos, a ideia de agencia vem se tornando, cada vez mais, uma concepção fundamental. Em detrimento das visões que prevaleceram entre os militares no início do século $X X$, que entendiam os rebeldes como ignorantes ou incapazes ou ainda das perspectivas das décadas de 1960 e 1970, que interpretaram seus atos como expressão de uma patologia ou apatia coletiva, surgem novos problemas e métodos que colocam em evidência a capacidade reflexiva e criativa desses grupos. Os atores históricos que participaram do conflito, são considerados, desde as últimas décadas do século $X X$, como responsáveis pelas escolhas $\mathrm{e}$ ações que realizaram, conscientes dos problemas enfrentados e capazes de formular projetos de transformação social.

Nesse movimento historiográfico de renovação, é importante considerar o papel fundamental que alguns pesquisadores têm exercido sobre as novas gerações de graduandos na área das ciências humanas. Um exemplo pode ser identificado nos diversos encontros realizados no Centenário do Contestado, durante o ano de 1912, organizados por Paulo Pinheiro Machado, Márcia Janete Espig e Delmir José Valentini ${ }^{13}$ e nas inúmeras publicações e jornadas acadêmicas que sucederam esses primeiros encontros. ${ }^{14}$

Uma dessas publicações demonstra a variedade de propostas e percursos teóricos e metodológicos adotados nos últimos anos. No livro, Contestado: fronteiras, colonização e conflitos (1912-2014), fruto das apresentações realizadas no II Simpósio Nacional sobre o Centenário do Movimento do Contestado: Fronteiras, Colonização, Conflitos e Meio Ambiente, que ocorreu em abril de 2014 em Chapecó, é possível observar os percursos adotados pelos pesquisadores do tema na atualidade. As analises giram em torno de temáticas como a legislação sobre terras, colonização e a questão agrária do planalto meridional brasileiro; a modernização e as relações sociais e políticas desenvolvidas a partir do estabelecimento de empresas estrangeiras na região; as narrativas visuais, os discursos memorialísticos, aspectos da religiosidade popular e da presença indígena na região; perspectivas da história da leitura, entre outras temáticas.

Essa grande variedade de objetos de estudo e de perspectivas norteadoras, demonstram o quanto a temática da Guerra do Contestado e dos movimentos sociais ganharam espaço na historiografia e na academia. Essa dinâmica de 
defesas de teses e dissertações, de publicação de livros e artigos, da realização de encontros e simpósios, indica que o tema está em construção e o interesse dos pesquisadores em evidenciar, cada vez mais, o papel dos sujeitos sociais que tiveram participação nos acontecimentos da época e na elaboração posterior de memórias sobre o conflito.

\section{Referências bibliográficas}

BACZKO, Bronislaw. Imaginação social. In: Enciclopédia Einaudi. AnthoposHomem. Lisboa: Imprensa Nacional-Casa da Moeda. 1985, p. 296-332. v. 5.

CARVALHO, F. S. de. Relatório apresentado ao General de Divisão José Caetano de Faria, Ministro da Guerra. Rio de Janeiro: Imprensa Militar, 1916.

DALFRÉ, Liz Andréa. Outras narrativas da nacionalidade: o Movimento do Contestado. Curitiba: SAMP, 2014.

DIACON, Todd. Millenarian Vision, Capitalist Reality - Brazil Contestado rebellion, 1912. Durham and London: Duke University Press, 1995.

DIÁRIO DA TARDE. Curitiba, 11 de outubro de 1912, n. 4196, p. 1, c. 4.

DIÁRIO DA TARDE. Curitiba, 15 de outubro de 1912, n. 4199, p. 4, c. 1.

DIÁRIO DA TARDE. Curitiba, 25 de setembro de 1912, n. 4182, p. 1, c. 6-7

26 DIÁRIO DA TARDE. Curitiba, 26 de setembro de 1912, n. 4183, p. 1, c. 5-6.

DIÁRIO DA TARDE. Curitiba, 4 de janeiro de 1915, n. 4983, p. 1. c. 4.

ESPIG, Márcia Janete. A presença da gesta carolíngia no movimento do Contestado. Canoas: ULBRA, 2002.

Personagens do Contestado: os turmeiros da Estrada de ferro São Paulo-Rio Grande (1908-1915). Tese (Doutorado em História) Departamento de História, Universidade Federal do Rio Grande do Sul, Porto Alegre, 2008.

FACÓ, Rui. Cangaceiros e Fanáticos. Rio de Janeiro, 1978.

GRUNER, Clóvis; PRIORI, Angelo (Org.). Contestado: 100 anos de uma guerra sem fim: movimentos e conflitos sociais no sul do Brasil: estudos sobre Santa Catarina e Paraná (séculos XIX e XX). Curitiba-PR: ANPUH, 2016, p. 13-28.

MACHADO, Paulo Pinheiro. Contestado: o centenário da guerra e o conflito sem fim. In: GRUNER, Clóvis; PRIORI, Angelo (Org.). Contestado: 100 anos de uma guerra sem fim: movimentos e conflitos sociais no sul do Brasil: estudos sobre Santa Catarina e Paraná (séculos XIX e XX). Curitiba: ANPUH, 2016, p. 13-28.

Lideranças do Contestado: a formação e a atuação das chefias caboclas (1923-1916). Campinas: Ed. Unicamp, 2004. 
MATTOS, Hebe. História e movimentos sociais. In: CARDOSO, Ciro Flamarion; VAINFAS, Ronaldo (Org.). Novos domínios da história. Rio de Janeiro: Elsevier, 2012, p. 95-112.

MONTEIRO, Duglas Teixeira. Os errantes do novo século: um estudo sobre o surto milenarista do Contestado. São Paulo: Duas Cidades, 1974.

PEREIRA, Osny Duarte. O cinqüentenário da guerra sertaneja do Contestado Paraná-Santa Catarina. Revista Civilização Brasileira, n. 9/10, p. 235246, 1966.

QUEIROZ, Maria Isaura Pereira de. 0 messianismo no Brasil e no mundo. São Paulo: Dominus, 1965.

QUEIROZ, Maurício Vinhas de. Messianismo e conflito social: a guerra sertaneja do Contestado (1912-1916). 2. ed. São Paulo: Ática, 1977.

RODRIGUES, Rogério Rosa. Os sertões catarinenses: embates e conflitos envolvendo a atuação militar na Guerra do Contestado. Dissertação (Mestrado em História) - Centro de Filosofia e Ciências Humanas, Universidade Federal de Santa Catarina, Santa Catarina, 2001.

- Veredas de um grande sertão: a Guerra do Contestado e a modernização do Exército brasileiro. Tese (Doutorado em História) Programa de Pós-Graduação em História Social, Universidade Federal do Rio de Janeiro, Rio de Janeiro, 2008.

VALENTINI, Delmir José; RODRIGUES, Rogério Rosa (Org.). Contestado: fronteiras, colonização e conflitos (1912-2014). Porto Alegre; Chapecó: Letra \& Vida; Ed. UFFS, 2015.

WELCH, Clifford Andrew. Movimentos sociais no campo até o golpe militar de 1964: a literatura sobre as lutas e resistências dos trabalhadores rurais do século XX. Lutas \& Resistências, v. 1, p. 60-75, 2006. 


\title{
Representación e historiografía: miradas múltiples al pasado de la Isla de Cubagua (1892-2014)
}

\author{
Representation and historiography: multiple looks to the past of the \\ Cubagua Island (1892-2014)
}

\author{
Fidel Rodríguez Velásquez* \\ fidelrodv@gmail.com \\ Maestría en Historia de las Américas \\ Universidad Católica Andrés Bello (UCAB) \\ Final Av. Teherán, Urb. Montalbán \\ Caracas, 1020, Apdo. 20.332 \\ Venezuela
}

\section{Resumen}

La isla de Cubagua ha sido representada en su pasado de múltiples maneras en la historiografía contemporánea, algunas veces como como sinónimo de Nueva Cádiz, otras veces como sinónimo de riqueza, explotación y catástrofes naturales. El presente trabajo constituye una aproximación a los discursos que sobre el pasado de la Isla de Cubagua se ha construido, para dar cuenta de las diversas miradas y enfoques, así como, de los diversos intereses que han orientado a los investigadores en la reconstrucción del pasado Cuagüense. Para ello se dividió la producción historiográfica en tres etapas. La primera de ellas denominada prospectiva, por el carácter pionero de los trabajos realizados en esta etapa, la segunda arqueológico-documental caracterizada por el papel de estas investigaciones en la producción de fuentes documentales y arqueológicas para el estudio del pasado de la Isla de Cubagua y la tercera como etapa interpretativa, pues en ella se dirigen los intereses de los investigadores a problemas específicos del pasado Cuagüense.

\section{Palabras clave}

Historia de América; Antropología histórica; Historiografía.

\begin{abstract}
Cubagua Island has been represented in the past in many ways in modern history, sometimes as synonymous with New Cadiz, sometimes as synonymous with wealth, exploitation and natural disasters. This work is an approach to the discourses on the past of Cubagua has been built, to account for the diverse perspectives and approaches, as well as the various interests that have guided researchers in the reconstruction of the past Cuagüense. For this historiographical production, it was divided into three stages. The first one called foresight, by the pioneering nature of the work carried out at this stage, the second archaeological documentary characterized by the role of these investigations in the production of documentary and archaeological sources for the study of the past in Cubagua and the third as an interpretive stage, because in it the interests of researchers target specific problems of the past Cuagüense.
\end{abstract}

\section{Keywords}

American History; Historical anthropology; Historiography.

Recibido el: 11/10/2016

Aceptado el: 4/2/2017

\footnotetext{
* Antropólogo egresado de la Universidad Central de Venezuela (UCV), en la actualidad cursa estudios de postgrado en Historia de las Américas en la Universidad Católica Andrés Bello (UCAB). Es investigador acreditado en la Categoría A2 por el Observatorio Nacional de Ciencia Tecnología e Innovación (ONCTI).
} 


\section{Representación e historiografía ${ }^{1}$}

Todas las sociedades, sean occidentales o no, poseen mecanismos de orden social que lespermiten representarse a sí mismas en su presente y su pasado, y por ende diferenciarse de otras sociedades generando de esta manera lo que podrían denominarse cartografías culturales en las cuales se define el adentro/ afuera y el nosotros/ellos que funda la construcción de identidades (AMODIO 1993). Estas representaciones no son estáticas, por el contrario revisarlas con profundidad histórica siempre permite observar y analizar las transformaciones que tienen lugar en esas representaciones y autorepresentaciones que pueden o no cambiar radicalmente dependiendo del periodo estudiado.

Cuando estudiamos estas representaciones del pasado en el caso específico de las sociedades occidentales, pueden tomarse dos caminos, el de las fuentes orales o el de la historia escrita, caminos que no necesariamente se encuentran separados, sino que por el contrario muchas veces se alimentan y realimentan constantemente entre sí. En el presente trabajo centraremos la mirada en un tipo específico de representaciones que tienen lugar sobre el pasado y es aquella que se hace desde las instituciones académicas, de esta forma analizaremos los discursos históricos sobre el pasado de la Isla de Cubaguacomo un tipo específico de producción cultural que se encuentra condicionada por los procesos de construcción de identidades de las sociedades presentes.

Asimismo, es necesario destacar que la multiplicidad de presentes desde los que se escriben los discursos históricos, muestran una diversidad de pasados, por lo que toda reconstrucción de carácter historiográfico debe necesariamente analizar la producción histórica considerando de manera específica las ideas, ideologías, intereses (académicos y políticos) y posturas de quienes son responsables de esta producción, para de esta forma poder valorar adecuadamente las contribuciones de cada uno a esa construcción del pasado, dejando siempre la posibilidad a que con nuevos datos o con nuevas miradas sobre los mismos datos puedan generarse mejores y más completas explicaciones sobre los procesos sociales que se aspiran estudiar.

La Isla de Cubagua se encuentra ubicada en el Mar Caribe, en conjunto con las islas de Margarita y Coche conforman el Estado Nueva Esparta de la actual República Bolivariana de Venezuela, la misma tiene una extensión territorial de $24,5 \mathrm{~km}^{2}$ y una extensión de costa de $26 \mathrm{~km}^{2}$, las máximas alturas de la isla no sobrepasan los $100 \mathrm{mts}$ de altitud. Esta porción de tierra en el mar entra en el escenario europeo a finales del siglo XV, específicamente en el año de 1498 cuando fue avistada por las naves que eran capitaneadas por Cristóbal Colon (OTTE 1977). Desde los primeros momentos de su encuentro con occidente, la isla de Cubagua paso a tener una importancia capital, puesto que en ella se estableció la explotación de los primeros bancos perlíferos en territorios americanos (PAYNE-IGLESIAS 2008). El encuentro de los marineros de Colon con los indígenas habitantes de la Isla de Cubagua es relatado por Fernández

\footnotetext{
${ }^{1}$ Quiero expresar mi agradecimiento al Arqueólogo Rodrigo Navarrete Sánchez y a la Antropóloga Julimar Mora por las discusiones sobre el pasado de la isla de Cubagua, muchos de los pasajes de este artículo fueron enriquecidos por esas discusiones.
} 
de Oviedo en su Historia General y Natural de las Indias señalando que una mujer con "una gran cantidad de hilos de aljófar" los intercambia por un "plato de los de Valencia" partido. Este relato da inicio a lo que podría denominarse "la época dorada de la isla de Cubagua" o al menos la de mayor importancia comercial desde el siglo XVI hasta la fecha. Las perlas de Cubagua llegaron a tener tanta importancia que se convirtieron durante los primeros momentos de colonización y conquista europea en territorios americanos en el principal rubro de exportación y llegaron a exhibirse como joyas en los vestidos y accesorios de los principales monarcas europeos, asimismo, estas joyas de la naturaleza fueron representadas e inmortalizadas en los cuadros del famoso pintor flamenco Theodor de Bry en sus serie titulada Grands voyages o Viajes a las Indias Occidentales (1590-1634) (BUENO JIMENEZ 1992).

En el pasado de la isla de Cubagua, hemos identificado tres etapas de la producción de los discursos históricos. La primera de ellas la hemos denominado etapa prospectiva (1892-1954) dedica a analizar los inicios del interés académico por el pasado de la Isla de Cubagua, la segunda arqueológico-documental (19551977), donde se realizaron los mayores aportes y se generaron las principales fuentes primarias con las que hoy en día se estudia el pasado de la Isla de Cubagua y una última etapa que hemos denominado interpretativa (19772014), ya no centrada en términos genéricos sobre la isla de Cubagua sino en problemas específicos vinculados a los diversos intereses de los investigadores.

\section{Etapa Prospectiva (1892 -1954): entre quimeras y realidades se entreteje el pasado de Cubagua}

El interés académico por el pasado de la Isla de Cubagua se inicia en Venezuela muy temprano a finales del siglo XIX, cuando en el año de 1892 el Dr. Arístides Rojas publica un artículo titulado El Escudo de Cubagua en el diario quincenal El Cojo Ilustrado en su volumen $n^{\circ} 6$ de fecha 15 de Marzo, en el reflexiona sobre la ciudad fundada por los españoles en esta pequeña Isla y sobre su importancia como la primera ciudad hispana erigida en los actuales territorios venezolanos, esta misma línea de reflexión será continuada por el autor en su columna Orígenes Venezolanos que será publicada el mismo año en los suplementos de este mismo diario. Posteriormente, en el siglo XX, específicamente, en el año de 1915 este interés se verá continuado con la visita a Venezuela del arqueólogo norteamericano Theodoor De Booy. Este investigador del Museum of American Indian vino con la intención de llevar adelante un proyecto general para conocer los restos de cultura material de los habitantes prehispánicos de Venezuela (DE BOOY 1916), la decisión de iniciar su proyecto en el oriente venezolano, específicamente en la Isla de Margarita estuvo muy ligada a la idea de reconstruir los primeros momentos del poblamiento de las Isla del Caribe considerando la proximidad de la Isla de Margarita con la Isla de Cubagua. Sin embargo, las dificultades de orden logístico circunscribieron sus primeras excavaciones a la Isla de Margarita y no a la Isla de Cubagua como era su idea inicial.

Sus excavaciones se realizaron específicamente en la zona noreste de la Isla de Margarita en la localidad de Girigire, donde se encontraron principalmente 
concheros y artefactos producidos con conchas, así como, restos óseos de humanos y mamíferos y un número considerable de fragmentos de vasijas con motivos antropomorfos y zoomorfos. No obstante, como señala el mismo autor también era común encontrar en casi todas las zonas de Margarita artefactos de piedra a través de la técnica de recolección superficial (DE BOOY 1916), especialmente, en las localidades de El Valle, la Asunción, San Antonio, Mosquito, Laguna Chica y la Sierra.

Sobre el trabajo de De Booy es importante señalar que se correspondía con el interés temprano de las instituciones académicas estadounidenses de tener un panorama completo sobre el pasado de las culturas prehispánicas americanas. La perspectiva de análisis encontrada en el trabajo de De Booy podría ubicarse dentro de lo que se denomina la Arqueología Tecnológica, es decir, una arqueología cuyo objeto central era el de definir los tipos de tecnología y comparar los hallazgos de producción de tecnológica de unos sitios con otros, para de esta forma establecer relaciones de cercanía o lejanía, por ello en el trabajo de De Booy no se encuentran inferencias de tipos etnológicas, así como tampoco reconstrucciones de las sociedades a partir de los restos de su cultura material.

Para ese momento no existía una tradición, ni una comunidad académica en Venezuela referente al estudio del pasado prehispánico, por lo que el trabajo de De Booy pasó de alguna manera inadvertido en el país. Sin embargo, tuvo un impacto importante en la incipiente comunidad arqueológica a principios del siglo XX, pues, las conclusiones de este trabajo permitían mostrar la existencia de un patrón tecnológico común en la Isla de Margarita, conclusiones que podían extenderse a la Isla de Cubagua y Coche, con las encontradas por el mismo autor en Santo Domingo, Cuba y Jamaica.

Posterior a este trabajo, el interés académicosobre el pasado de la Isla de Cubagua vendría del campo de la Literatura con la publicación de Enrique Bernardo Núñez de la novela Cubagua en el año de 1931.Cubagua viene a representar un esfuerzo importante por representar en este génerosus tesis histórico-historiográficas (STRAKA 2015) que sin lugar a dudas toman una distancia importante de la mirada que hasta el momento había sido dominante, la de la Venezuela Heroica (1881) de Eduardo Blanco. Cubagua viene a representar esa primera mirada al pasado venezolano en la que no destacan los grandes héroes a caballo ylas grandes hazañas militares por liberar las tierras americanas del llamado imperio español, por el contrario, Cubagua representa como señala Suarez (2014) "otra historia", la de la vida cotidiana, la de otros actores sociales distintos a las elites y los grandes héroes del ejercito patriota. En ella personajes como Arimuy, Fray Dionisio y Tiberio Mendoza, dan vida a una historia, en la cual, Núñez nos ofrece una particular visión sobre el pasado y el presente venezolano, pero escenificado en la Isla de Cubagua. El éxito de su novela fue tan importante que logrócolocar a la Isla en el imaginario de las elites letradas venezolanas, despertando de esta forma un interés importante sobre su presente y su pasado, sobre todo, por el papel de ciudad fundadora de la presencia hispánica en América, teniendo esto, importantes consecuencias en términos de la construcción de la identidad nacional. 
Volviendo al campo de las Ciencias Históricas, ${ }^{2}$ las primeras menciones al pasado de Isla de Cubagua tienen lugar en 1940 en trabajos muy generales y centrados en las ideas referentes a la desaparición de la ciudad de Nueva Cádiz realizados por Casto López en su libro La Margarita, Isla Venezolana de las Perlas y por Centeno Grau en su obra Estudios Sismológicos. Esta misma línea de trabajo continua en 1947con Julio Febres Cordero en su libro Hacia una nueva Geografía (VILA 1948). Posterior a esto se realizaron en el año de 1948 las primeras expediciones nacionales con las visitas realizadas a la Isla por Pablo Vila, quien, acompañado por el médico Italiano radicado en la población de Punta de Piedras Iscilio Crisci, Alfredo Boulton y sus estudiantes del Instituto Pedagógico de Caracas, estuvo realizando algunas prospecciones y recolecciones superficiales de restos de cultura material con el objetivo de demostrar que la Ciudad de Nueva Cádiz no había sido destruida por un terremoto sino por un huracán y por tanto aún seguía bajo tierra (OTTE 1977, p. 564). A partir de esta visita se iniciaron un conjunto de expediciones por parte de otros investigadores donde destacan las realizadas por Jesús Mata de Gregorio y el Lino Moulines, y por una comisión de la Universidad Central de Venezuela encabezada por Miguel Acosta Saignes donde también participaron el profesor José Antonio de Armas Chitty y nuevamente el profesor Jesús Mata de Gregorio (CRUXENT 1972).

A raíz de estas visitas vieron la luz los primeros trabajosrealizados con mayor especificidad sobre la Isla de Cubagua, nos referimos específicamente a los de Pablo Vila (1948), José de Armas Chitty (1951), Miguel Acosta Saignes 32 (1953; 1954) y José María Cruxent (1955). Este florecimiento de los trabajos académicos sobre el pasado de la Isla de Cubagua estuvo también caracterizado por una multiplicidad de intereses y de posturas teórico-epistemológicas por parte de los investigadores de las cuales, se desprenden claramente tres líneas de trabajo. La primera, donde se ubican tanto Pablo Vila como José de Armas Chitty, es decir, la historia tradicional caracterizada por el uso de fuentes documentales provenientes de los archivos, donde destaca el carácter narrativo de la historia a construir. Asimismo, es importante destacar la postura de ambos investigadores en relación al origen de la nación venezolana, puesto que Vila como Armas Chitty hacen un énfasis importante en igualar el pasado de Cubagua con el pasado de Nueva Cádiz para de esta forma,representar una historia de estos territorios que tendría su origen con la llegada de los españoles a América. Dentro de esta línea de trabajo destacan fundamentalmente dos temas que luego pasaran a formar parte del imaginario venezolano con respecto a la Isla de Cubagua: la extracción de perlas y la ciudad hundida por un cataclismo.

La segunda línea de trabajo se encuentra representada por Acosta Saignes quien, interesado en el pasado prehispánico, escribe el enigma de los Guaiqueríes como uno de los ensayos que forma su obra Estudio de Etnología Antigua, en ella, el autor ofrece una visión etnológica sobre el pasado de los habitantes de la Isla de Cubagua, discutiendo sobre su origen étnico y su adscripción lingüística, asimismo, ofrece una visión de conjunto respecto a lo que el denominaría la

2 Para profundizar en esta definición de ciencias históricas, ver Vargas Arenas (1986). 
zona Circuncaribe. Acosta Saignes construye esta visión a partir de fuentes documentales y relatos de los cronistas, la cual, se ve impregnada de teoría antropológica para buscar de esta forma lo que el mismo autor denomino la síntesis etnológica. Esta visión propuesta por Acosta Saignes ofrece por primera vez en Venezuela la posibilidad reflexionar el pasado prehispánico desde una perspectiva interpretativa donde no se generaliza a los habitantes prehispánicos en términos culturales, asimismo, el texto ofrece una visión sobre la importancia que el autor le da al pasado prehispánico en términos de la construcción de la identidad nacional y la formación de la venezolanidad, queda claro que para Acosta Saignes la historia de los territorios que en la actualidad conforman la República Bolivariana de Venezuela no comenzó con la colonización hispana en siglo XVI. Esta postura lo llevara tener una polémica importante con Arturo Uslar Pietri a través de artículos de prensa publicados por el Diario El Nacional durante la década de 1950 los temas centrales de esta polémica fueron la identidad nacional, el pasado prehispánico y la concepción de la historia.

La tercera línea de trabajo es la visión arqueológica representada por José María Cruxent, quien inicia sus trabajos de campo en la Isla de Cubagua en el año de 1954 en compañía del arqueólogo norteamericano John Goggin de la Universidad de Gainesville, ubicada en Florida. Los intereses de ambos investigadores eran muy diversos, Goggin tenía como idea central la de recolectar alfarería española, pues, se encontraba para ese momento realizando un proyecto continental sobre la mayólica española en territorio americano, en cambio los intereses de Cruxent eran más diversos puesto que estaba interesado tanto en la ocupación hispana, como en la presencia de materiales prehispánicos en la Isla. De estas primeras excavaciones arqueológicas son publicados unos resultados incipientes en la revista farol en el año de 1955 bajo el nombre de Nueva Cádiz, Testimonio de Piedra donde nuevamente se observa el interés por representar el pasado de Cubagua como el pasado de la Ciudad de Nueva Cádiz.

Esta primera etapa de la historiografía sobre la Isla de Cubagua la hemos denominado prospectiva, puesto que en ella se tienen lugar los primeros intereses sobre el pasado de la Isla y ven la luz las primeras publicaciones que de una u otra manera trazarían desde diversas perspectivas lo que sería el futuro de los estudios sobre el pasado de la Isla de Cubagua.

\section{Etapa Arqueológico - Documental (1955 - 1977): entre tiestos y textos aflora el pasado de la Isla de Cubagua}

\section{Lo que dicen los tiestos...}

Esta segunda etapa inicia con la continuación de las excavaciones arqueológicas realizadas en la Isla de Cubagua por parte de Cruxent y Goggin, donde el hallazgo de una vasija llena de perlasobtuvo una notoriedad importante por los medios de comunicación de la época, lo cual, tuvo dos consecuencias importantes, la primera de ellas alimentar el imaginario de la sociedad venezolana con respecto a la Isla de Cubagua y la Ciudad de Nueva Cádiz como un lugar 
Ileno de riquezas y el segundo, que el gobierno nacional proveyera los fondos necesarios para que Cruxent ampliara y continuara sus excavaciones en la isla.

Esta ampliación de los trabajos arqueológicos permitió una división más clara del trabajo y de los intereses, mientras Goggin continúo excavando las ruinas de la Ciudad de Nueva Cádiz ubicada en la zona este de la Isla de Cubagua, Cruxent en compañía de otro arqueólogo norteamericano llamado Irving Rouse excavo diferentes lugares de la Isla ubicando tanto sitios prehispánicos, como sitios que denomino indohispánicos por la coexistencia de material indígena con material hispánico.Las excavaciones en la antigua ciudad de Nueva Cádiz permitieron reconstruir gran parte del trazado de la ciudad y la recuperación de gran cantidad de materiales de uso diario de las personas que ahí habitaban, entre ellos: porcelanas, vidrios, metales azulejos e incluso, el escudo y un par de gárgolas pertenecientes al antiguo convento de San Francisco, también se encontraron otros artefactos de cerámica y adornos que indicarían la presencia en la Isla de indígenas provenientes de tierra firme y otras islas del caribe, muy probablemente, con el objetivo de ser utilizados como mano de obra en la extracción perlífera (MOLINA 1998).

Los resultados de estos trabajos fueron publicados en los años de 1959 por Cruxent en un texto titulado An archeological chronology of Venezuela y posteriormente, en 1963 en otro texto tituladoVenezuelan Archeology en coautoría con Irving Rouse. Por otro lado, Goggin public en 1968 Spanish Majolica in the New World: Types of the 16th to 18th Centuries. Las principales conclusiones de los trabajos de Cruxent y Rouse respecto al pasado prehispánico de la Isla de Cubagua apuntan a siete ocupaciones sucesivas en la zona, cuya evidencia se encuentra en 5 complejos divididos en dos grupos, un primer grupo conformado por los complejos Cubagua (4.320 - 3.725 años Antes del Presente), Manicuare (3.725 - 1.895 años AP) y Punta Gorda (1.895 - 1.580 años AP)pertenecientes a la Serie Manicuaroide que son considerados como complejos precerámicos. Esta serie se define a partir de la presencia de puntas de hueso, gubias de concha y la piedra de dos puntas. En el segundo grupo se encontró material de origen hispánico e indígena, si bien, el mayor grupo de este material son las llamadas Ruinas de la Ciudad de Nueva Cádiz o complejo Nueva Cádiz (500 años A. P), también es importante mencionar al complejo Obispo (500 años AP).En el caso del trabajo de Goggin, Spanish Majolica in the New World: Types of the 16th to 18th Centuries, permitió identificar las diversas rutas de entrada de la mayólica española en el continente americano, siendo una de las primeras rutas utilizadas a principios del siglo XVI la Isla de Cubagua.

También es importante resaltar las características de la arqueología practicada por Goggin, Rouse y Cruxent, la cual, podría ubicarse con una gran influencia europea, específicamente, de la escuela historicista que se encontraba en pleno apogeo. Esta escuela de pensamiento privilegiaba una "Visión artefactual y descriptiva que pretendía ofrecer una síntesis cronológica cultural a través de la definición estilística artefactual" (NAVARRETE SÁNCHEZ 2010, p. 130) de esta forma, tiene mucho peso para estos autores la estratigrafía, la descripción y la definición de complejos y series; en cambio, se encuentra una ausencia total de 
propuestas etnológicas que permitan ahondar su relación con la cultura material y los grupos étnicos del presente y del pasado. También es importante destacar la influencia que tuvieron los autores de la arqueología norteamericana, pues, en el momento en que estos se encontraban realizando sus excavaciones se estaba también gestando una importante escuela de pensamiento conocida como arqueología histórica, la cual, reivindica el papel de la arqueología en la construcción de las representaciones y discursos históricos que servirán de soporte para la construcción de identidades nacionales y de lo que se ha denominado los usos políticos del pasado.

\section{Papeles viejos ¿Qué dijeron los documentos?}

Posterior a los trabajos arqueológicos, a principios de los años 60 comienzan a materializarse los esfuerzos de la fundación John Boulton por la reconstrucción del pasado de la Isla de Cubagua, en el verano de ese año su presidente Alfredo Boulton invita al historiador español Enrique Otte a Venezuela y lo contrata para escribir una historia de la Isla de Cubagua (OTTE 1977), pero dicha historia, no podría ser escrita sin un importante trabajo de recolección de documentos antiguos en el Archivo de Indias ubicado en Sevilla, labor de la que prontamente se ocupó el historiador.

Es por ello que para el año de 1961 vería la luz los primeros esfuerzos, con la publicación del Cedulario de la monarquía española relativo a la Isla de Cubagua, ${ }^{3}$ el cual constituye hasta el día de hoy el intento más importante por reunir en una sola publicación todas las cedulas reales referentes a la Isla de Cubagua que se conservaron en las distintas secciones del Archivo General de Indias, en total se recogen 427 cedulas reales transcritas como señala el mismo Otte utilizando el método comúnmente aceptado para la época en Venezuela.

En esta misma década, pero en el año de 1967 sería publicado otro importante trabajo donde se incluiría una sección dedicada a la Isla de Cubagua, nos referimos al trabajo de Pablo Ojer La formación del Oriente Venezolano ${ }^{4}$ el cual se nutre tanto de los cedularios recogidos por Otte como de la importante colección de documentos trasladadas por el mismo y por Herman González Oropeza al Instituto de Investigaciones Históricas de la Universidad Católica Andrés Bello (UCAB) a partir de los índices de los documentos relativos a Venezuela ubicados en el archivo General de Indias elaborados por el Hno. Nectario María. Esta colección de documentos proviene del Archivo General de Indias (Sevilla), el British Museum (Londres), el Public Record Office (Londres), Bodleian Library (Oxford), Archives Nationales (Paris), Archivos General de Simancas (Valladolid), el Archivo Nacional y la Biblioteca Nacional (Madrid). El trabajo de Ojer puede considerarse como un trabajo pionero en la zona, al punto que élmismo señala que la historia del oriente de Venezuela, se encuentra en muchos aspectos "donde la dejaron los cronistas", asimismo, también es importante señalar la amplitud del marco geográfico y

\footnotetext{
3 Publicado en el año de 1961 en una edición conjunta entre la Fundación John Boulton y la Fundación Eugenio Mendoza Quintero.

${ }^{4}$ Este trabajo fue presentado como tesis doctoral por Pablo Ojer ante la Universidad Javeriana de Colombia y publicado por la Universidad Católica Andrés Bello.
} 
temporal de la investigación del profesor Ojer puesto que abarcó todo el siglo XVI y los territorios que van desde Piritu hasta Guayana, incluyendo las Islas que en la actualidad conforman el estado Nueva Esparta nos referimos a Margarita, Coche y Cubagua. El aspecto central del trabajo está referido a la creación de las gobernaciones como primeras instituciones hispanas en el continente.

Una década más tarde, en 1977, sería publicado el trabajo de Enrique Otte tituladolas Perlas de Caribe: Nueva Cádiz de Cubagua, en el cual el autor recoge los resultados de años de investigación dedicados a los documentos que la monarquía española expidió para la Isla de Cubagua, se trata de un trabajo minucioso en el que se analiza el auge y caída de la ciudad de Nueva Cádiz como asentamiento español y su relación con la explotación de las perlas en las primeras cuatro décadas del siglo XVI. La obra de Otte ofrece una visión de conjunto sobre la sociedad hispana que tiene lugar en la Isla de Cubagua, pero siempre manteniendo cada aspecto de la vida social en articulación con la explotación perlífera, el trabajo se divide en dos partes, la primera de ellas titulada Las perlas del caribe, donde el autor sitúa a Cubagua y su importancia en el escenario mundo del siglo XVI y una segunda parte titulada Nueva Cádiz de Cubagua, en la que Otte se pasea minuciosamente por esta sociedad donde como el mismo señalada la perla, ese pequeño tesoro producto de la introducción de cuerpo extraño en el interior de un molusco bivalvo denominado Pteria, lo significó todo.

Estos dos trabajos constituyen los trabajos históricos más importantes 36 publicados referentes al pasado de la Isla de Cubagua, asimismo, es importante resaltar el significativo trabajo de recolección documental hecho por los autores, al punto que en la actualidad tanto los documentos recopilados por Otte como por Ojer en los archivos europeos continúan siendo los fondos documentales más importantes que se tienen en Venezuela para estudiar los primeros momentos de la presencia hispana en el continente y por lo tanto son de obligatoria consulta para quien emprenda una investigación de este periodo tan importante y al mismo tiempo tan poco estudiado. Es por ello que a la hora de valorar la importancia de estos dos trabajos para la historiografía venezolana y en particular para la historiografía cuagüense y oriental, no dudamos en catalogarla de muy significativa, no solo por las dimensiones y lo minucioso de sus trabajos si no porque sus recopilaciones documentales pusieron al alcance de muchos investigadores interesados en estos temas las fuentes primarias para muchos estudios que incluso en la actualidad aun estar por hacerse.

A modo de cierre de esta etapa que hemos catalogado de arqueológicodocumental y hemos ubicado temporalmente entre 1955 y 1977, podríamos decir que ha dado los frutos más importantes hasta la actualidad en cuanto a la reconstrucción del pasado de la Isla de Cubagua, puesto que el carácter general y pionero tanto de las investigaciones arqueológicas como documentales realizadas significaron la apertura de grandes líneas de trabajo y dejaron para el futuro la posibilidad de dar cabida a nuevas miradas y nuevos enfoques sobre problemas específicos que la amplitud de estas obras no pudo y no tenía como objeto resolver. 


\section{Etapa Interpretativa (1977 - 2014): Cubagua nuevos retos, nuevas miradas}

La década de los 80 significó un vacío en cuanto a la producción historiográfica sobre el pasado de la Isla de Cubagua, pareciera que la comunidad académica necesitó de una década para digerir el ampliamente sustentado trabajo de Enrique Otte, no será hasta finales de esa década cuándo volverán a ver la luz investigaciones referentes al pasado cuagüense, pero esta vez desde la arqueología, con los aportes de Mario Sanoja Obediente (1989) con el trabajo titulado Origins of Cultivation around the gulf of Paria, North eastern Venezuela, donde a partir de las excavaciones del sitio La Aduana, ubicado en la Isla de Cubagua, y los sitios Manicuare, Indismo, Laguna Grande, Las Varas, No Carlos, Remigio y Guayana ubicados en el norte del estado Sucre, y su posterior análisis en relación con los cambios ecológicos dentro de los cuales se encuentran la aparición de ambiente de manglar y las fluctuaciones en el nivel del mar del mar. Las principales conclusiones del trabajo de Sanoja Obediente apuntan a una importante transformación de la economía, la tecnología y la organización social de los grupos que habitaban esta zona con el fin de sacar provecho delas cambiantes condiciones ecológicas de finales del pleistoceno, dentro de estos cambios el autor menciona la creación de enclaves sedentarios o semisedentarios para adquirir y procesar los alimentos; la explotación estacional de recursos naturales; la iniciación de la pesca y la recolección especializada en lagos, mares y ríos; así como, desarrollos tecnológicos tales como arcos y flechas, arpones, redes de pesca, anzuelos, embarcaciones y la navegación, gubias para trabajar madera y hachas y azuelas para limpiar y preparar los campos para el cultivo.

El principio de la década de los años 90 coincidió con la llamada "celebración" de los 500 años de la presencia europea en los territorios americanos impulsada por la Agencia de Cooperación Internacional Española y algunos gobiernos latinoamericanos, en este marco tuvo lugar una polémica muy importante sobre el presente, el pasado y el futuro de la Isla de Cubagua a raíz de los inicios de un proyecto turístico que buscó convertir a la Isla en un gran complejo con hoteles 5 estrellas y campos de golf. Los preacuerdos entre el Estado venezolano y una compañía transnacional desataron la polémica, por paradójico que parezca, las principales herramientas utilizadas por quienes adversaban el megaproyecto turístico fueron precisamente las Investigaciones tanto de José María Cruxent como de Enrique Otte, dando esto una prueba importante de los usos políticos del pasado, esta vez como arma para defender lo que en ese entonces sus líderes consideraban el derecho de los margariteños y los venezolanos a ser dueños de lo que fue la primera ciudad hispana en Venezuela, a raíz de este movimiento vio la luz un pequeño libro titulado Cubagua: un llamado a la conciencia nacional (1991) cuyo autor fue el historiador Iván Gómez, la polémica se saldó en un debate nacional en el antiguo congreso de la republica que terminaría por prohibir el megaproyecto hotelero.

Posteriormente, el interés sobre el pasado cuagüense, continuó con la aparición de dos trabajos importantes, nos referimos específicamente a la investigación de María Ángeles Eugenio (1992) titulada Una empresa de perlas: los Barrera en el caribe centrada en historiar la familia Barrera como actores 
clave en el comercio de perlas y el trabajo realizado por Reitz (1993) The spanish colonial experience and domestic animalsdonde se analiza la experiencia española en la introducción de animales europeos en las islas de la Hispaniola, Cubagua y Florida. Estos dos trabajos, así como, el de Sanoja Obediente (1989) muestran un cambio importante en la forma de los investigadores de acercase a los problemas sobre le pasado cuagüense, mientras en la etapa anterior las investigaciones tenían una mirada totalista, en esta etapa se busca dar respuesta a problemas específicos sobre el pasado de la Isla de Cubagua.

Para el año de 1995 Sanoja Obediente y Vargas Arenas publicarán Gentes de la Canoa, donde ofrecerán una nueva interpretación acerca del pasado Cuagüense, pero esta vez desde la perspectiva de la arqueología social latinoamericana. ${ }^{5}$ De esa manera los conceptos bajo los cuales se llevó adelante la interpretación del pasado fueron los de modo de vida, procesos productivos, modo de trabajo y fuerzas productivas para dar cuenta en última instancia de la sociedad que habitó la Isla de Cubagua. Las principales conclusiones de este trabajo señalan la preferencia de los antiguos pobladores de Cubagua por la navegación de alta mar, la recolección de moluscos marinos y el trueque de mercancías como sal, con grupos que habitaban las cosas de los actuales territorios de Venezuela. Sus principales industrias de manufactura estuvieron basadas en el procesamiento de madera, fibras, conchas y piedras. Asimismo, en términos de relaciones sociales, el registro estratigráfico muestra una serie sucesiva de ocupaciones que se van complejizando por el aumento de la intensidad de la explotación de los recursos marinos y por el aumento de la densidad poblacional. Otra de las conclusiones más importantes es la referente a las condiciones para establecer la vida social a partir del desplazamiento constante entre las islas, generando de esta forma itinerarios de viaje cíclicos asociados al desplazamiento de las fuentes de alimentos.

Un año después se publica el trabajo de Ayala Lafee (1996) La Etnohistoria Prehispánica Guaiquerí, dando continuidad al interés sobre los grupos étnicos que habitaron las islas de Margarita, Coche y Cubagua, en este trabajo la autora ofrece una visión de conjunto donde por primera vez se busca lograr una síntesis interpretativa a partir de los datos arqueológicos, los relatos de los primeros viajerosy los documentos oficiales de la época. Construyendo de esta forma una visión etnológica del pasado del pueblo Guaiquerí donde la Isla de Cubagua juega un papel central.

En esta misma década se inicia la producción historiográfica de Fernando Cervigón, ${ }^{6}$ cuyos intereses dieron sus frutos en tres publicaciones, Cubagua 500 años (1997), La Perla (1997) y Las Perlas en la historia de Venezuela (1998),

\footnotetext{
${ }^{5}$ La arqueología social latinoamericana, es una corriente de pensamiento dentro del campo de la arqueología que aspira a la compresión científica del pasado a partir de la aplicación de los conceptos del marxismo, tiene su origen en el año de 1976 con los intelectuales latinoamericanos que integraron el grupo de Teotihuacán, para conocer en mayor profundidad sobre esta corriente, ver Lumbreras (1976); Sanoja Obediente y Vargas Arenas (1992) y Navarrete Sánchez (2007).

${ }^{6}$ Fernando Cervigón proviene originalmente del campo de la biología marina y durante más de veinte años cultivo una estrecha relación con la Isla de Cubagua y especialmente con los pescadores con quienes convivio en largas temporadas mientras realizó sus trabajos de ictiología de donde se publicaron los ocho volúmenes que componen la obra de Los peces marinos de Venezuela, como el mismo señala, de estas largas estadías en la Isla proviene su interés por la historia de esta pequeña porción de tierra.
} 
cuya valor fundamental radica en el carácter divulgativo y educativo que las mismas tuvieron, la obra del Dr. Cervigón tuvo un importante impacto en las escuelas margariteñas donde volvió a reposicionar el interés por el pasado de la Isla de Cubagua y su valor patrimonial.

Volviendo nuevamente a la mirada etnológica, Silva Suniaga (2006) realizó una importante investigación a partir de los relatos de los cronistas de indias sobre la etnicidad de los habitantes de las Islas de Cubagua, Margarita y Coche que tituló Los Guaiqueríes: el enigma de un pueblo. Más recientemente destacan los trabajos de investigación realizados sobre el pasado de la Isla de Cubagua por investigadores europeos y norteamericanos, dentro de estos se puede mencionar los realizados por Tardieu (2008) Perlas y piel de azabache. El negro en las pesquerías de las indias occidentales donde diserta sobre el papel de los esclavos africanos en la extracción de perlas, así como las redes comerciales que se tejieron entorno a estos; el de Michael Perri (2009) Ruined and Lost: Spanish Destruction of the Pearl Coast in the Early Sixteenth Century donde basado en los trabajos de Ojer y Otte ${ }^{7}$ el autor centra su mirada en el daño al medio ambiente, la esclavitud y la desaparición de las poblaciones que para el momento habitaban la isla.

En los últimos 5 años se han publicado 3 artículos sobre el pasado de la Isla de Cubagua, uno de Alfredo Bueno Jiménez(2012) quien vuelve a centrar su mirada en el negocio de la explotación perlífera en su texto La granjería de Perlas en el nuevo mundo y dos de Molly Warsh quien escribió Enslaved Pearl Divers in the Sixteenth Century Caribbean (2010) y A political ecology in the early spanish caribbean (2014), el primero de ellos referido al tema de los esclavos dedicados al rescate de perlas y el segundo a comprender aspectos de las ecología política vinculados al rescate de perlas en las granjerías hispanas, dando una preponderancia importante a la propia comprensión de los habitantes sobre la necesidad de preservar su ambiente.

Esta última etapa de la producción historiográfica sobre el pasado de la Isla de Cubagua tiene como característica central la hiperespecialización de los temas de estudio, así como, un cambio en la perspectiva de estudio, no son nuevas fuentes documentales ni nuevas excavaciones arqueológicas lo que ha posibilitados nuevas formas de entender y comprender el pasado de la Isla de Cubagua, sino por el contrario, las nuevas investigaciones sobre el pasado cuagüense han sido posibles por aplicar nuevos enfoques y nuevas perspectivas sobre los datos y las fuentes que se tenían.

\section{Consideraciones finales}

Esta aproximación al estudio de la historiografía sobre la Isla de Cubagua, ha permitido un recorrido por los diversos intereses de los investigadores que sobre ella han centrado su mirada y ha hecho posible comprender las diversas valoraciones y representaciones que sobre la isla de Cubagua se han configurado, 
así hemos sido testigos de una Cubagua hispánica, la de la Ciudad de Nueva Cádiz, aquella donde tienen lugar los relatos históricos más conocidos sobre el pasado cuagüense compuestos fundamentalmente de perlas, esclavitud y desastres naturales. Sin embargo, antes y después de estos relatos más conocidos como nos muestra Acosta Saignes, José María Cruxent, Mario Sanoja Obediente, Iraida Vargas, Ayala Lafee y Silva Suniaga existió una Cubagua diferente, una Cubagua donde las puntas de huesos, los artefactos líticos y las gubias de conchas marinas componen sus vestigios más prominentes, como testigos de una sociedad diferente que con sus transformaciones aún persiste en algunas comunidades de la región insular.

Este recorrido historiográfico muestra muchas historias de Cubagua, incluso muchas de ellas aun no escritas, sin embargo, una valoración justa nos permitiría afirmar que todas y cada una de ellas aportan una dimensión, un interés, una mirada particular, por lo que toda producción histórica debe valorarse en su justa medida como una aproximación al conocimiento específico de un segmento de la historia cuagüense, teniendo siempre conciencia de que el futuro muy probablemente abrirá paso a nuevas fuentes, a nuevos enfoques o simplemente nuevas realidades del presente desde donde se escribe la historia que permitirán nuevos intereses y nuevas conclusiones sobre el pasado.

\section{Referencias bibliográficas}

ACOSTA SAIGNES, Miguel. Zona Circuncaribe: periodo indígena. México: Instituto panamericano de Geografía e Historia, 1953.

. El enigma de los Guaiqueríes. In: Estudios de Etnología Antigua de Venezuela. La Habana: Casa de las Américas, 1961, p. 171-187.

AMODIO, EMANUELE. Formas de la alteridad: construcción y difusión de la imagen del indio americano en Europa durante el primer siglo de la conquista de América. Quito: Editorial Abya Yala, 1993. v. 6.

ARMAS CHITTY, José. Origen y Formación de algunos pueblos de Venezuela. Caracas: Tip. Americana, 1951.

AYALA LAFEE, Cecilia. La etnohistoria prehispánica Guaiquerí. Antropológica, v. 82, 1996.

BUENO JIMÉNEZ, Alfredo. La "Granjería de las perlas" en el Nuevo Mundo. Cuadernos Americanos, v. 142, p. 83-111, 2012.

CERVIGÓN, Fernando. Cubagua 500 años. Caracas: Fundación Museo del Mar, 1997.

La perla. Pampatar: FONDENE, 1997.

. Las perlas en la historia de Venezuela. Caracas: Fundación Museo del Mar.1998.

CRUXENT, José María. Nueva Cádiz, testimonio de piedra. El Farol, n. 160 p. 2-5, 1955. 
An archeological chronology of Venezuela. Washington: Pan American Union, 1959.

- Algunas noticias sobre Nueva Cádiz (isla de Cubagua) Venezuela.

Memorias de la VI Conferencia Geológica del Caribe. Margarita, Venezuela, p. 33-35, 1972.

CRUXENT, Jose Maria; ROUSE, Irving. Arqueología cronológica de Venezuela. Caracas: Armitano, 1982. v. I-II.

DE BOOY, Theodoor. Notes on the archeology of Margarita Island, Venezuela. Contribution from de Museum of the American Indian. New York: Heye Foundation, 1916.

EUGENIO, María. Una empresa de perlas: Los Barrera en el Caribe. Actas XI jornadas de Andalucía y América, p. 9-37,1992.

GOGGIN, John. Spanish majolica in the New World: types of the sixteenth to eighteenth centuries. Haven: Yale University Press,1968.

GÓMEZ, Iván. Cubagua: un Ilamado a la conciencia nacional. Caracas: Editorial Abrebrecha, 1991.

LUMBRERAS, Luis Guillermo. La Arqueología como Ciencia Social. Lima: Ediciones Hista, 1974.

MOLINA, Luis. Cubagua: patrimonio histórico y cultural de Venezuela y América. Caracas: Instituto de Patrimonio Cultural,1998.

NAVARRETE SÁNCHEZ, Rodrigo. La Arqueología social latinoamericana: una meta, múltiples perspectivas. Caracas: Cuadernos CODEX - FaCES Universidad Central de Venezuela, 2007.

El cacique imaginado: Miguel Acosta Saignes y los modelos de complejidad social para la Venezuela prehispánica. Revista Venezolana de Economía y Ciencias Sociales, v. 16, n. 1, p. 129-143, 2010.

OJER, Pablo. La Formación del Oriente Venezolano. Caracas: Universidad Católica Andrés Bello,1966.

OTTE, E. Cedularios de la monarquía española relativos a la Isla de Cubagua (1523-1550). Caracas: Fundación John Boulton y Fundación Eugenio Mendoza, 1961.

. Las perlas del Caribe: Nueva Cádiz de Cubagua. Caracas: Fundación John Boulton, p. 564,1977.

PAYNE-IGLESIAS, Elizeht. Las perlas de la reina: explotación perlífera en el Pacífico de Centroamérica (1522-1850). Diálogos - Revista electrónica de Historia, n. esp., p. 631-654, 2008.

PERRI, Michael. Ruined and Lost': Spanish Destruction of the Pearl Coast in the Early Sixteenth Century. Environment and History, v. 15, n. 2, p. 129161, 2009. 
REITZ, Elizabeth. The Spanish colonial experience and domestic animals. Historical Archaeology, v. 26, p. 84-91, 1993.

ROJAS, Aristides. El Escudo de Cubagua. El Cojo Ilustrado, v. 6, 15 mar. 1892.

ROUSE, Irving; CRUXENT, Jose Maria. Venezuelan archaeology. New Haven: Yale University Press,1963. v. 6.

SANOJA, Mario. Origins of Cultivation around the Gulf of Paria, Northeastern Venezuela. National Geographic Research, v. 5, n. 4, p. 446-458, 1989.

SANOJA, Mario; VARGAS ARENAS, Iraida. Antiguas formaciones y modos de producción venezolanos. Caracas: Monte Ávila Editores, 1978.

- Gente de la Canoa. Economía Política de la Antigua Sociedad Apropiadora del Noreste de Venezuela. Caracas: Fondo Editorial Tropykos - Comisión de Estudios de Postgrados - FaCES, Universidad Central de Venezuela, 1995.

SILVA SUNIAGA, Juan. Los Guaiqueríes: el enigma de un pueblo. Caracas: El Perro y la Rana, 2006.

STRAKA, Tomas. Enrique Bernardo Núñez y las tramas de la Historia. In: ARRÁIZ LUCCA,Rafael; HERNÁNDEZ DELFINO, Carlos (Comp.). 25 intelectuales en la Historia de Venezuela. Caracas: Fundación Bancaribe, 2015, p. 257-266.

SUAREZ, Carlos. Arqueología, representación y patrimonio: las otras historias de Cubagua y Nueva Cádiz. Revista Nuestro Sur, n. 8, p. 41-57, 2014.

TARDIEU, Jean Pierre. Perlas y piel de azabache. El negro en las pesquerías de las Indias Occidentales. Anuario de Estudios Americanos, v. 65, n. 2, p. 91-124, 2008.

VARGAS ARENAS, Iraida. Arqueología, ciencia y sociedad. Boletín de antropología americana, v. 14, p. 5-52,1986.

VILA, Pablo. ¿La destrucción de Nueva Cádiz Terremoto o huracán? Boletín de la Academia Nacional de la Historia, v. 31, n. 123, p. 213-219, 1948. - Margarita en la Colonia, 1492-1550: los comienzos del poblamiento. Revista Nacional de Cultura, año 11, n. 81, p. 59-85, 1950.

. Las Actividades Perlíferas y sus vicisitudes en Venezuela. Revista de Historia, año III, n. 17, p. 13-3, 1963.

WARSH, Molly. Enslaved Pearl Divers in the Sixteenth Century Caribbean. Slavery and Abolition, v. 31, n. 3, p. 345-362, 2010.

. A political Ecology in the early Spanish Caribbean. William and Mary Quarterly, s. 3, v. 71, n. 4, p. 517-548, 2014. 


\title{
Viera y Clavijo: Historiador ilustrado del Atlántico
}

\section{Viera y Clavijo: Enlightenment Historian Atlantic}

\author{
Juan Manuel Santana Pérez \\ jmsantana@dch.ulpgc.es \\ Catedrático de Historia Moderna \\ Universidad de Las Palmas de Gran Canaria-Espanha \\ ULPGC - c/ Pérez del Toro, 1 \\ 35003 - Las Palmas de Gran Canaria \\ España
}

\begin{abstract}
Resumen
Analizamos la producción historiográfica de Viera y Clavijo, ilustrado canario que tuvo una obra destacada en el conjunto de España. Hemos hecho una labor hermenéutica de su obra, así como la incorporación de informaciones que están en archivos canarios. Creemos que hace falta profundizar en su filosofía de la historia. La obra historiográfica de Viera y Clavijo fue la primera visión de conjunto de la Historia de Canarias en concordancia con las ideas ilustradas, especialmente influenciado por historiadores franceses, que sin ser la más vanguardista en Europa, supuso un enorme paso adelante en el pensamiento canario de la segunda mitad del siglo XVIII. Al tiempo que destaca la atlanticidad de Canarias, también destaca las características conferidas por la insularidad. La geografía fue un aspecto que Viera y Clavijo estimaba que dificultaba la propagación de las ideas religiosas e ilustradas. La separación insular, con una orografía accidentada, hacía que determinados lugares fueran inaccesibles. La identidad canaria es deudora de la obra de Viera y Clavijo, muchos de sus mitos e imaginarios arrancan de su Historia y continúa en esos cánones de la ilustración canaria dieciochesca.
\end{abstract}

\section{Palabras claves}

Ilustración; Historiografía; Identidad.

\begin{abstract}
We analyze the historiographical production of Viera y Clavijo, enlightenment canary that had an outstanding work in the whole of Spain. We have made a hermeneutic work with this work, as well as the incorporation of information that Canary files have. There is a need to deepen their philosophy of history. Historiographical work of Viera y Clavijo was the first overview of the history of the Canary Islands in accordance with the enlightened ideas, especially influenced by French historians, without being the most avant-garde in Europe, was a huge step forward in the Canary thought of the second half of the eighteenth century. While stressing the Atlanticism of Canarias, also it highlights the characteristics conferred by insularity. Geography was an aspect that Viera estimated that hindered the spread of religious and enlightened ideas. The island apart with a rugged terrain, made certain places inaccessible. The Canarian identity is indebted to the work of Viera y Clavijo, many of their myths and imaginary tear from his history and continues in those canons of eighteenth-century Canarian illustration.
\end{abstract}

Keywords

Enlightenment; Historiography; Identity.

Recibido el: 4/8/2016

Aceptado el: 6/4/2017 
En la Corona española durante el absolutismo borbónico, las artes y el saber lograron un reconocimiento oficial con la fundación de las Academias reales como la Real Academia de la Historia en 1738. Además, en tiempos de Carlos III se organizaron los Archivos Históricos de Indias y de la Corona de Aragón.

Las Islas Canarias fueron un área semiperiférica del Imperio hispano, pero vivió avances culturales fruto de una élite ilustrada encargada de fomentar e impulsar el aparato productivo, movido por un interés bien entendido que la llevaba a preocuparse de la situación económica del campesinado, así como a emplear nuevos métodos para intervenir con consejos y órdenes en las obsoletas estructuras. En estas islas hubo una importante actividad intelectual que se movía en el marco del horizonte de ideas ilustradas nada despreciables y comparables con otras experiencias dentro de la Corona española, de hecho, se avanzó en los conceptos agronómicos y se intentó llevarlas a la práctica, aunque con poco éxito entre otras razones por la falta de medios $y$, sobre todo, por la verticalidad con que pretendían aplicarlas. En este contexto, la recuperación de la historia formaba parte de ese gran plan de conocimiento de los pueblos y fomento de las actividades culturales. En Canarias el personaje más destacado de este movimiento ilustrado fue José de Viera y Clavijo.

A pesar de que es bien conocida la biografía de José de Viera y Clavijo, creemos preciso señalar algunos datos básicos para entender sus concepciones filosóficas y, en consecuencia, historiográfica. Nació el 28 de diciembre de 1731 en el Realejo de Arriba, en la isla de Tenerife, su padre era alcalde de la localidad, ${ }^{1}$ y murió en la ciudad de Las Palmas el 21 de febrero de 1813. Pronto se mudó con su familia al entonces Puerto de La Orotava, hoy Puerto de la Cruz, allí recibió su primera formación; se trataba de una localidad portuaria abierta a la llegada de productos, personas y costumbres europeas. Estudió teología y filosofía escolástica en el convento de Santo Domingo de La Orotava. En 1753 es subdiácono y, más tarde, accedió a las órdenes mayores para conseguir el presbiteriado en Gran Canaria. En 1757 pasó a residir con sus padres a la ciudad más importante de Canarias del momento, La Laguna, allí entró en contacto con los ilustrados canarios, incluso formó parte de la Tertulia de Nava. En 1770, bajo el reinado de Carlos III, en el momento del auge de la Ilustración española, se estableció Madrid, en la casa del marqués de Santa Cruz, quien marcará sus pasos en la Corte, fue ayo de su hijo primogénito. Desde allí recorrió buena parte de Castilla y Andalucía. La experiencia y el conocimiento de los viajes por Europa constituyeron un eje crucial en la formación de las elites ilustradas canarias (GALVÁN 2013, p. 23-36). En 1777 viaja por Francia y Flandes acompañando al joven Marqués del Santa Cruz, y en 1781, acompañando al propio Marqués de Santa Cruz padre por Italia, Austria y Alemania. Sobre los viajes de Viera tenemos un artículo que analiza de forma impecable lo que le aportó y condicionó en su obra esas experiencias (GALVÁN 1996, p. 655-668). Ese año permanece en Madrid y es nombrado por el Rey arcediano de Fuerteventura, importante

\footnotetext{
${ }_{1}$ Tenemos la partida de bautismo en una hoja de papel sellado con fecha de 5 de enero de 1732 en Archivo del Museo Canario-Las Palmas de Gran Canaria (A.M.C.), Colección de Documentos de Agustín Millares Torres, Tomo VIII, Legajo 4, s/fl.
} 
cargo eclesiástico, pero aun retrasó el retorno a las Islas dos años, es decir, que en 1783 ya está instalado en su puesto catedralicio de Canarias hasta su muerte, en la isla de Gran Canaria. En su vida fue polifacético, como gran parte de los intelectuales ilustrados, historiador, poeta, autor de una novela, eclesiástico, traductor, docente, educador, orador sacro, naturalista y periodista.

Los años de la madurez de Viera supondrán para el Archipiélago el primer brote de una nueva concepción en todos los ámbitos del pensamiento.

La Ilustración canaria estuvo apuntalada firmemente desde el principio por ciertos sectores eclesiásticos que, a pesar de parecer contestatarios para su época, se metieron de lleno en la tarea por modernizar y actualizar las estructuras sociales, económicas y culturales del Archipiélago.

El pensamiento ilustrado en Canarias llegará por medio de libros extranjeros que entraban por vía marítima, por donde penetraron las ideas, tanto impresas, como en las mentes de liberales y heterodoxos que arribaron a nuestros puertos en este periodo.

Será una Ilustración que impacte en los círculos aristocráticos y terratenientes, la tónica general en toda la Corona, sin embargo, habrá una diferencia destacable en la norma, ya que el pueblo llano de las Islas va a tomar contacto con el fenómeno, aunque solamente en instancias superficiales.

\section{Publicación de la Historia de Viera y Clavijo}

Casi todos los historiadores canarios dedicados a indagar en el pasado del Antiguo Régimen han escrito muchas páginas sobre este autor, de hecho, no hay libro que trate sobre las Islas Canarias entre los siglos XVI y XVIII que no tenga alguna referencia a Viera, siempre encontraremos alguna cita pertinente al respecto, incluso en la historia de la historiografía española del siglo XVIII debería aparecer reseñado. Creemos que su obra está a la altura de la Historia Literaria de España de los hermanos Mohedano (1766-1791) y de la Historia crítica de España y de la cultura española de J. F. Masdeu (1783-1805).

La monumental obra de Viera y Clavijo continúa siendo de obligada consulta para cualquier investigación histórica de Canarias con anterioridad al siglo XIX, además de algunos poemas con eminente contenido histórico. Su magna obra historiográfica apareció con el largo título: Noticias de la historia general de las Islas Canarias. Contienen la descripción geográfica de todas. Una idea del origen, carácter, usos y costumbres de sus antiguos habitantes: De los descubrimientos y conquistas que sobre ellas hicieron los Europeos: De su Gobierno Eclesiástico, Político y Militar: Del establecimiento, y sucesión de su primera Nobleza: De sus Varones ilustres por dignidades, empleos, armas, letras, y santidad: De sus fábricas, producciones naturales, y comercio; con los principales sucesos de los últimos siglos; ${ }^{2}$ este tipo de títulos no eran infrecuentes en la época, al contrario.

\footnotetext{
${ }^{2}$ Hay un ejemplar original de los cuatro tomos en Archivo de la Real Sociedad Económica de Amigos del País de Tenerife (A.R.S.E.A.P.TFE), Fondo Rodríguez Moure, Sig: 22/86. También un borrador anotado y con dibujos del autor, con fecha de 1763, Sig: 20/7. Existe una edición facsímil publicada por el Gobierno de Canarias en 2004. Tenemos unos apuntes manuscritos del autor sobre este libro en A.M.C., Colección de Documentos de Agustín Millares Torres, Tomo VIII, Legajo 11, 8 fls.
} 
El libro fue publicado en cuatro tomos, impresos en Madrid, donde Viera se trasladó a vivir en 1770, tengamos en cuenta que en ese momento Canarias únicamente contaba con una imprenta establecida en Santa Cruz de Tenerife instalada en 1751 que era muy deficiente porque había sido formada con unos tipos viejos y gastados procedentes de Sevilla (LAFORET 1991, p. 19-20). Los cuatro tomos salieron respectivamente en 1772, 1773, 1776 y 1783 (CEBRIÁN 1996, p. 209-220), sacó 1.000 ejemplares de cada tomo por 35.000 reales en la imprenta de Blas Román, aunque sabemos que la había terminado de escribir muchos años antes de su publicación; el primer libro lo acabó de redactar en 1763 y en 1766 los seis siguientes.

Estructurado en 19 libros, hace un repaso completo de la Historia de Canarias. Dado que fueron apareciendo a lo largo de once años, pudo ir incluyendo nuevas informaciones en los largos prólogos que acompañaron a cada tomo, que en el caso del volumen tercero le ocupó 17 páginas. También en medio del texto podemos apreciar algunas rectificaciones con respecto a afirmaciones anteriormente publicadas, de hecho, a medida que fue editando los tomos posteriores trató de perfeccionarlos y en sus años de residencia en Madrid tuvo la oportunidad de contrastar determinadas informaciones.

Aunque es la obra más valorada de Viera y Clavijo, sin embargo, este libro no tuvo una buena acogida en su tiempo, no sabemos por qué; el propio autor se quejaba: "He publicado una obra que pocos compran, nadie lee y que muchos critican... este diluvio universal de críticas, murmuraciones y bravatas". No obstante, otros coetáneos suyos afirmaron que había diferentes opiniones, pero no dejaron de señalar los diversos ataques. ${ }^{3}$ A. Humbolt utilizó la Historia de Viera para preparar la escala que hizo en Tenerife en 1799, esto le confirió a la obra cierta relevancia europea.

Las cuentas que hizo el historiador fueron detalladas, minuciosas, revelaban el método con que siempre trabajó, característica de su personalidad ordenada. Por el análisis de esas cuentas sabemos que no anduvo muy sobrado de dinero con esta publicación ${ }^{4}$. En el segundo volumen, el autor da la noticia que el Cabildo de Tenerife había acordado darle cien ducados de ayuda para sufragar cada uno de los cuatro tomos, el acuerdo fue tomado en tres sesiones, pero nunca recibió los cuatrocientos ducados (BLANCO 1950, p. XXIV-XXV).

Según Juan Régulo (1981, p. 90), esta obra ha servido de arranque a toda la historiografía posterior del Archipiélago, sin haber sido superada por una similar visión, en conjunto, de la historia de Canarias. Quizás hoy en día es una afirmación algo exagerada.

\section{El Atlántico}

Podemos considerarlo historiador atlántico, aunque todavía de forma embrionaria, de hecho, desde el primer libro, nuestro autor asevera la africanidad de Canarias: "Estas islas pertenecen a África", de este modo comienza el primer

\footnotetext{
${ }^{3}$ A.M.C. Archivo Viera, Caja 3, sin/fol.

${ }^{4}$ A.R.S.E.A.P.TFE, Fondo Rodríguez Moure, Sig: 10/390, Manuscrito. Están editadas las cuentas que muestran esa contabilidad (ROMEU 1981, p. 122-141)
} 
capítulo del Libro Primero, así como su interés en referirlas como porciones de la antigua Atlántida. Llamar la atención a una evidencia, es decir, que Canarias se halla en África era situarla en el Atlántico, y salir del mediterráneocentrismo dominante desde inicios de la Edad Moderna (WULFF 2003), además, al ubicarla en su punto geográfico ponía en la palestra la lejanía de la Península Ibérica y con ello que al Archipiélago le afectaba su proximidad continental y su proyección hacia América, con notoria diferencia con respecto a las otras regiones de España y, esto había condicionado su sociedad. Viera afirma que los guanches procedían de "linaje de héroes atlánticos".

Se maneja entre la africanidad geográfica y la americanidad emocional, característica que ha sobrevivido en la cultura canaria. Nilo Palenzuela (1981, p. 33) ha señalado la voluntad universalista y mitopoética de Viera dentro de su mirada insular. En su Historia se reconoce que los canarios hablaban una lengua africana, aunque los hace descendientes de una mítica y heroica civilización atlántica. Fajardo $(2009$, p. 100, 110) señala con acierto que la obra se centra en el carácter atlántico de la población insular, como originaria y autóctona, unido a que la Dedicatoria, inédita en su tiempo, a Carlos III, escribe literalmente "desde el seno del Mar Atlántico".

Al tiempo que destaca la atlanticidad de Canarias, también destaca las características conferidas por la insularidad. La geografía fue un aspecto que Viera estimaba que dificultaba la propagación de las ideas religiosas e ilustradas. La separación insular, con una orografía accidentada, barrancos, precipicios, montañas, caminos impracticables, hacía que determinados lugares fueran inaccesibles, quedando por tanto fuera de los esfuerzos pastorales.

El análisis de las "tablas y materias" de los cuatro tomos es muy indicativo de su concepción de la Historia, muestra detalladamente lo que nos vamos a encontrar en el contenido.

Tras la reafirmación de la africanidad geográfica que hemos señalado, pasa a describir el espacio, la posible formación territorial, sin renunciar a encajarlo en los esquemas bíblicos, y las primeras noticias conocidas en el mundo clásico del Archipiélago con una explicación de los topónimos e introduce en un capítulo final el tema mítico de la isla de San Borondón, que aparecía y desaparecía, hoy sabemos que se debe a un fenómeno óptico en determinadas circunstancias.

En este mismo libro dedica los capítulos del 9 al 13 a demostrar que las Islas Canarias son los restos del antiguo continente de la Atlántida. En la creencia en el continente de la Atlántida hay un intento de desacralización acorde con el proceso de secularización y regalismo que se vive en España a lo largo del siglo XVIII. En la Biblia debía estar contenida una explicación para las poblaciones de todo el planeta. Viera recoge que en Canarias, siguiendo el pensamiento judeocristiano que creía que todo partía del pueblo judío, aseveraban la idea bíblica que todo el poblamiento del mundo procedía del Cercano Oriente, donde habría estado el paraíso terrenal, se pensaba que los aborígenes isleños procedían de los descendientes de Noé, concretamente de sus hijos Cam y Jafet ya que Fut, un hijo del primero había ido hacia África, además, en Éxodo capítulo 36 versículo 36 se refiera a un personaje Ilamado Gomer, hijo del citado Jafet, y en 
algún momento fue asimilado con el nombre original de la isla de La Gomera. Las Sagradas Escrituras no podía quedar al margen de la crítica general. La Historia de Viera abandona las interpretaciones providencialistas, no podía estar al margen de las orientaciones críticorracionalistas y, de este modo, se superaba la visión historiográfica agustiniana, en la que la Providencia dominaba las intenciones de los seres humanos y todo en la Historia se dirigía a la salvación o condenación de un mundo futuro. La crítica es una actividad misma de la razón que trata de obtener por medio del pensamiento racional, conocimientos exactos. Con estas afirmaciones, acorde con la cultura ilustrada, se distancia del judeocentrismo que insinuaba que todo el mundo se había formado en torno a la nación judía. Algo similar hizo el marqués de Valdeflores en Los Anales de la nación española, que escribió en 1759, donde elimina una filiación directa que conecte la historia bíblica con los orígenes de España (ÁLVAREZ 1996, p. 160).

No obstante, el primer ilustrado español que rompió con la tradición de buscar el origen bíblico que procede de los "falsos cronicones" fue Gregorio Mayans que redescubrió y publicó en 1742 a quien había sido el primer crítico: el fraile Nicolás Antonio del siglo XVII y su obra inédita Censura de historias fabulosas (PASAMAR 2010, p. 11, 33, 35 y 40). Este ilustrado ha sido profundamente estudiado y recuperado para el conocimiento historiográfico español (MESTRE 1978; 1990; 1999; 2007).

\section{Nativos canarios}

El libro segundo está dedicado íntegramente a las sociedades aborígenes de cada isla, aportando datos históricos y antropológicos, así como políticos de los primeros canarios. Aquí radica su originalidad y la diferencia fundamental con las otras historias de España del siglo XVIII. En las referencias a los guanches aproxima, en muchas ocasiones, la historia a la mitología, aparecen como atlantes, sitúa a esta cultura aborigen próxima al mito de la Edad de Oro dentro del mito de las tres edades, son idealizados, modestos, generosos con honor. Hay una inspiración rousseauniana pero Viera siempre se mostró respetuoso con el dogma católico.

Viera representó un nuevo modo de tratar la historia del Archipiélago y la evolución de su configuración cultural. El aborigen ocupó un lugar central porque era su propio objeto de estudio. Nos muestra la sociedad aborigen idealizada, caracterizada por un primitivismo, donde abandona los principios escépticos y su enfoque racionalista (CASTRO 1996, p. 703-725). Para él, el guanche, viene a encarnar el papel del "buen salvaje" de sus maestros franceses, hacia ellos presenta una actitud comprensiva, mientras que los conquistadores y los misioneros serán el blanco de sus críticas (ESTÉVEZ 1987, p. 71, 73), los considera "afortunados" por ese estado de primitivismo, ingenuidad, naturalidad, sencillez y armonía con la naturaleza que le acercan al prerromanticismo. Realmente Viera aporta poco a sus fuentes ilustradas, insiste que eran de "costumbres simples", "valientes, generosos, fieros y celosos de su libertad natural" con una vida sencilla, defendía su tierra y ensalzaba sus costumbres. Para los ilustrados, ya no quedaban verdaderos salvajes, se habían transformado, aunque de 
sus antiguas enseñanzas podíamos obtener lecciones morales y políticas. En cualquier caso, el "buen salvaje" fue la expresión de la mala conciencia del pensamiento ilustrado del siglo XVIII (ESTÉVEZ 2008, p. 92).

En un contexto similar, el problema del indio americano, la naturaleza del Nuevo Mundo y las consecuencias de las conquistas perpetradas por los españoles se debatieron durante todo el siglo XVIII (GONZÁLEZ 1992, p. 11-40). Muchos misioneros idealizaban al indio, pero también hubo otros que lo describieron con cruel severidad; los jesuitas ponían de relieve aspectos negativos pero esos aspectos eran los que mejor hacían resaltar la firmeza, la paciencia, el espíritu de sacrificio de los buenos padres (GERBI 1982, p. 81). Además, hubo una corriente seguidora de corte rousseauniano que consideraba, como sabemos, al hombre en estado natural como civilizado y al hombre social como corrompido. A partir del Discours sur l'origine et les fondements de l'inégalité de 1754, el mito del noble salvaje fue expandiéndose por Europa dentro de la idea de las poblaciones primitivas.

Los conquistadores son censurados en algunas de sus actitudes por su crueldad mientras que el aborigen es elogiado. El pasado aborigen es concebido en los marcos convencionales tópicos del imaginario pastoril y de la oda heroica, y en un mundo equivalente al de los héroes griegos que no deben ser sometidos a la crítica racional (ARENCIBIA 1996, p. 15). No obstante, Viera escribe siempre como europeo, esa crueldad del conquistador es a veces necesaria, de hecho, siempre habla en primera persona del plural, se reconoce parte de esos castellanos. La entronización de las diversas dinastías insulares aborígenes las pone en relación con las grandes monarquías europeas y la presenta como la consagración del absolutismo, y explica cómo los primeros "reyezuelos" se transformaron en déspotas (CASTRO 1996, p. 584).

También es destacable que, bajo las influencias del interés por la egiptología del siglo XVIII, estableció algunas relaciones entre las momias guanches con las de Egipto, sin base experimental, a pesar de eso, todavía hallamos historiadores canarios que tratan de establecer relaciones de este tipo, amparándose en esas afirmaciones de nuestro ilustrado para sustentar diversas teorías acerca del origen de los primitivos canarios.

\section{Historiografía ilustrada}

En el tomo tercero aparecen las primeras referencias de su autor a problemas económicos de Canarias, reflejando una visión de la Historia como un todo interrelacionado en que los pueblos y los hombres juegan un papel heroico y simultáneamente malvado (BERGASA 2008, p. 25).

La parte dedicada a los siglos del Antiguo Régimen debe mucho a la historia genealógica, dado que los acontecimientos aparecen al hilo de las vidas de los sucesivos señores de las respectivas islas o al del examen del mando desempeñado por las autoridades superiores de las islas realengas (CASTRO 1996, p. 112).

Durante el siglo XVIII habrá cuatro esferas que atraigan la curiosidad historiográfica: la Historia inmediata como memorias y diarios; la Historia de 
Ios Estados por medio de la de sus príncipes; la Historia de Roma, no obstante, el rápido descenso de la redacción en lengua latina de las obras históricas; la Historia exótica, del extremo Oriente y de América como la de los orígenes de los Estados europeos (CARBONELL 1981, p. 101-102). En el caso de la Historia de Canarias nos movemos entre lo exótico del archipiélago y algunas de sus relaciones con América, y, por otro lado, el interés por la inmediatez en algunos capítulos de los 19 libros, inaugurando una historia regional, de las primeras de España, que siguió practicándose en los siglos XIX y XX en toda Europa. Intentó dar una visión de conjunto de Canarias como parte integrante de la historia universal, que confería al Archipiélago un reconocimiento e identidad de pueblo.

Su visión de la Historia está mediatizada por dos aspectos esenciales: la clase social a la que pertenecía y, su propia formación ilustrada.

En España, a partir de comienzos del siglo XVIII, nos encontraremos con una serie de trasformaciones que irán marcando el proceso de secularización de la vida social, política y económica, acelerado en el último tercio de la centuria.

Los Reyes favorecieron una insólita perspectiva de monopolio ideológico en favor de las ideas ilustradas, las cuales fueron forjadas por una minoría y mantenidas entre luz y sombra.

En el siglo de las luces se produce una reacción, que hacía falta, contra la preocupación por la historiografía militar, dinástica y diplomática. Se dio una nueva importancia a los factores culturales e intelectuales, y se atendió a la vida del pueblo y a los hábitos y costumbres de los hombres en las diferentes sociedades, por eso la Historia de Viera y Clavijo no es una mera historia militar y de relaciones internacionales como se había venido haciendo, sino que está a tono con estas ideas ilustradas, con preocupación por la sociedad, la economía, la naturaleza, la salud. Combina, de forma convincente, la erudición con la interpretación.

Tal vez por su condición eclesiástica o por el carácter confesional de la monarquía española, dedica muchas páginas a la historia de la iglesia y de la religión. En los siglos XVI y XVII la mayoría de las obras históricas introducían el vector religioso-eclesiástico (SÁNCHEZ MARCOS 2003, p. 135-136). Durante el siglo XVIII español hallamos historias eclesiásticas como la del ilustrado valenciano Enrique Flores que ponía el énfasis en los aspectos que tocaban a las leyendas piadosas y patrióticas (FLORES 1747-1777).

La Iglesia canaria en estos momentos atraviesa una etapa clave, ya que se encuentra ante la tesitura de elegir entre la tradición y las luces innovadoras. En el contexto de la obra historiográfica de Viera, la Iglesia trató de desarrollar un papel reformista y de avance, con la destacada actuación de tres obispos: Juan Bautista Cervera (1769-1777), Joaquín Herrera de la Bárcena (1779-1783) y Antonio Tavira y Almanzán (1791-1796). Los ilustrados se preocuparon a nivel individual de lo que algunos calificaron "excesiva credulidad del pueblo llano o analfabetismo religioso", así Viera y Clavijo escribió algunas obras sobre asuntos religiosos con afán crítico, bastante avanzado para la época. Otro problema con que se tropezó la Iglesia canaria fue la contextura sociológica que imponía ciertas particularidades, puesto que se trataba de una población heterogénea en 
sus orígenes y que había ido teniendo continuos cruces, bien por asentamientos extranjeros o por contactos comerciales, como la afluencia de población del continente africano, negros y moriscos. Esta particularidad obligaba a una cierta flexibilidad a la hora de aplicar las normas que no se daba en otras áreas del resto de la Corona española.

Todos estos aspectos hoy en día siguen siendo preocupación de la historiografía canaria, ahora por distintos intereses. En el pensamiento ilustrado la Historia es un instrumento para promover la reforma de la sociedad y, al mismo tiempo, la Historia era otro campo a reformar debido a la pasividad mostrada por la Real Academia. Como ha señalado Antonio Mestre, "todo ilustrado era un reformador que buscaba en la historia la solución a las deficiencias de su tiempo" (MESTRE 1990, p. 60). Y Viera se mueve en el mundo reformista del reinado de Carlos III, reformas que querían hacer ver al mundo su especial atención a los asuntos canarios y americanos.

Los conceptos claves de la Ilustración, "razón", "naturaleza" y "cultura", intervienen con una plenitud que parece dirigida a compensar el cúmulo de irracionalidades que caracteriza a su momento histórico.

Hubo una transformación de la idea de progreso a finales del siglo XVIII, estudiada por Koselleck (2012, p. 95-112), paulatinamente, se abandonó la vieja noción de que el mundo envejecía y corrompía inexorablemente, al igual que el cuerpo humano, y se adoptó la idea de que, quizá, el avance de las ciencias y del conocimiento llevaría a la humanidad al completo hacia la prosperidad permanente.

A pesar de ese individualismo radical, la organicidad del orden estamental no desaparece totalmente. El primer cometido que se adscribe a las leyes consiste en la determinación de los oficios, otros tantos vehículos que canalizan las acciones individuales "al bien general", punto de encuentro de la felicidad individual y de la social. De ahí que la sociedad sea vista no sólo como ámbitos de derechos, sino también de deberes recíprocos (ELORZA 1989).

La conciencia política generada con la Ilustración suscitó también un amplio interés por la Historia en toda Europa. Desde 1663 se funda en París la Acedémie des inscriptions et des belles lettres, que se dedicaba al estudio de la Historia y, a imitación de ésta, se fueron fundando otras similares en diversos países a lo largo del siglo XVIII (HOF 1993, p. 52, 94). En Francia vemos un nutrido grupo de historiadores que escriben sobre el pasado bajo las ideas ilustradas. Algo parecido ocurrió en casi todos los países europeos donde había avanzado más la Ilustración con la proliferación fundaciones de Academias (BARRET-KRIEGEL 1998).

El ideal moderno de cultura siempre ha estado asociado con el saber histórico y antropológico. En el plano teórico, toda la historiografía de nuestra época ha estado fuertemente vinculada al proyecto moderno.

Se partía de la premisa de que existe un estado social, político, económico ideal, y todo el pasado constituye el camino en pro de ese fin. La filosofía de la Historia ilustrada trata los aspectos de en qué medida, bajo qué condiciones y hasta qué punto la Historia, en cuanto evolución de la comunidad humana, puede llevar a la realización del bien. 
Por medio de esa concepción del progreso, plantea que para saber si el hombre va a mejor, se debe hacer una Historia profética de los hechos futuros, haciendo esa elaboración a priori de los acontecimientos que van a ocurrir. Esto es posible cuando el historiador-profeta, hace y ejecuta los hechos que anuncia con anticipación (KANT 1987, p. 56), así en su Historia General vemos que Viera cree en la cultura del progreso, mito de la historia.

Viera supera con creces las historias del siglo XVII que ni tan siquiera, ofrecían las fuentes de las que tomaban los datos. Pretendía poner en marcha el proyecto a partir de tres pilares fundamentales: la documentación, la multidisciplinariedad, y la duda metódica (SANTANA 1999).

\section{Fuentes de la Historia de Viera}

Pudo consultar importantes documentos en la Santa Sede, en Roma, especialmente las bulas papales en que se nombraba a Canarias. En una carta que envía a Antonio Porlier desde Viena el 10 de enero de 1781, confiesa entusiasmado que en ese archivo descubrió "muchas bulas originales, y noticias no menos curiosas que ignoradas por lo que han de dar una nueva luz a las antigüedades de aquella Iglesia" (VIERA 1984, p. 61). También pudo obtener información del archivo Secreto de la Catedral de San Ana en la ciudad Las Palmas, lo ordenó y catalogó; halló bulas del siglo XIV, rescriptos papales, cédulas reales, innumerables cartas y documentos, libros de registro y administración, etc. (SÁNCHEZ RODRÍGUEZ 2007, p. 78).

No obstante, las fuentes fundamentales de su libro fueron Le Canarien (que pudo adquirirlo en París), crónica escrita por dos frailes normandos y, por otro lado, la crónica de Abreu Galindo, aunque las somete a un relativo espíritu crítico, propio de los ilustrados. Debemos añadir el conocimiento de la Información de Pérez de Cabitos de 1477 que se conserva en El Escorial. Realmente, copia la historia de los primitivos canarios, pero con algunas aplicaciones de ciertos esquemas y conocimientos propios del siglo XVIII europeo.

Nuestro autor leyó muchos textos que se referían a la historia de Canarias, que ninguno poseía un discurso histórico riguroso. Criticó duramente la obra de Núñez de la Peña $(2008)^{5}$ por la cantidad de imprecisiones, llegó a afirmar que se trataba de un hombre sin demasiada instrucción ni estilo, que le llevó a hacer una "historia insípida, envuelta en muchos arcaísmo, errores y equivocaciones", tal como dice en el prólogo, incluso dedica dos capítulos titulados "Equivocaciones de Núñez de la Peña. ${ }^{6}$ Viera y Clavijo también sacó cinco números de un periódico manuscrito, elaborado íntegramente por él, donde trata de un cargo defensor de los intereses populares, el Síndico Personero, y allí también hace referencia al historiador aludido de forma crítica, dirá "sólo sirven nuestros Personeros para fijar las épocas de nuestra historia o para añadir cada uno un renglón a la estéril

\footnotetext{
5 También sabemos que Viera y Clavijo manejó los trabajos de Núñez de la Peña porque Lope Antonio de la Guerra y Peña se los envió desde Tenerife, conservamos la copia de dicho documento en A.M.C., Colección de Documentos de Agustín Millares Torres, Tomo III, Legajo 3, fls. 22 recto-25 vuelto.

${ }^{6}$ El capítulo XLVIII del libro séptimo y el capítulo XIX del libro octavo.
} 
cronología de D. Juan Núñez de la Peña".7 Algo similar sucede con el poeta Viana (1996) a quien tilda de "falso adalid" (VIERA 2004, p. 2-3), o fray Alonso de Espinosa (1980) de quien dice que tenía la "incertidumbre como fusión". Del mismo modo, sabemos que manejó como fuentes históricas los libros de José de Sosa (1849), Marín y Cubas (1986), Bartolomé García del Castillo (2003) o Pedro Agustín del Castillo (2008), a todo ello le añadió la consulta de los libros de acuerdos del cabildo de Tenerife y reales cédulas.

Más que un detallado trabajo de archivos, hace un trabajo bibliográfico, tuvo siempre un entorno personal en el que los libros y la escritura ocuparon el lugar más relevante (LUXÁN 2007, p. 24). Lo cierto es que pudo consultar los archivos oficiales, así como documentos facilitados por otros ilustrados que hacían de corresponsales en las islas, especialmente otros participantes de la Tertulia de Nava, en La Laguna, que había impulsado la obra. Tomás Lino de Nava-Grimón Porlier coordinaba las informaciones remitidas por una red conformada por José Antonio de la Guerra y Fernando de Molina y Quesada en Tenerife, José Van de Walle en La Palma, Fernando de la Guerra ${ }^{8}$ en Lanzarote y un "amigo anónimo" en Fuerteventura (HERNÁNDEZ 2006, p. 58). Sabemos que también colaboraron otros importantes ilustrados como Lope de la Guerra y Peña, citado en el prólogo del segundo tomo, tenemos constancia que recopiló la historia de las fundaciones de parroquias y conventos de Tenerife que Viera empleó en el tomo IV de su magna obra. ${ }^{9}$

No obstante, hay una ausencia de utilización de fuentes diferentes, no ofrece varias versiones de un acontecimiento determinado, como por ejemplo cuando habla del garoé, el mítico árbol herreño donde se deja llevar por la versión de un testigo.

A su favor podemos señalar que en ocasiones se lleva por el sentido común y la racionalidad propia de la Ilustración, así como una actitud crítica personal que muchas veces coincide con investigaciones posteriores. Crea, interpreta y piensa a partir de unos hechos. Pero, aunque trata de fechar con exactitud, es objetable el desinterés por la cronología entre los acontecimientos que aparecen, por ejemplo, en el capítulo XXVIII del libro octavo en el volumen segundo, introduce la experiencia del británico George Glas en 1764, mientras que el resto de ese libro habla del proceso de conquista en el siglo XV.

Además, obtuvo una licencia para leer libros prohibidos, aunque sufrió diversos problemas relacionados con la Inquisición debido a los peligros de historiar en esa época. Debemos reconocer que algunos de los hechos denunciados por el Santo Oficio canario contienen inexactitudes y no son imparciales, por lo que la Inquisición pretendió que suprimiese algunos párrafos. Las críticas se centran concretamente en las querellas del obispo Rodrigo de Roxas; sabemos que Viera se equivoca (probablemente de forma intencional) sobre la condena

\footnotetext{
7 Archivo de la Biblioteca Municipal de Santa Cruz de Tenerife (B.M.S/C. TFE), Signatura: 11-2-6, tomo VI, Memoriales del Síndico Personero. Memorial I, 20-1-1764, fl. 56 recto. Existe una edición impresa de los 5 números de este periódico editado por NEGRÍN (1994).

${ }^{8}$ El marqués de San Andrés, Fernando de la Guerra, envió información a Viera sobre los condes de La Gomera, como se conserva en A.M.C. Colección de Documentos de Agustín Millares Torres, T. V, Leg. 2, fols. 37 r.-40 r.

${ }_{9}^{9}$ A.M.C. Colección de Documentos de Agustín Millares Torres, Tomo III, Legajo 10, fls. 77 r-112 v.
} 
final en la versión ofrecida en esta Historia acerca del proceso inquisitorial y la sentencia de Cristóbal del Hoyo Solórzano, marqués de San Andrés y vizconde de Buen Paso, dado que el marqués nunca fue absuelto, ni los inquisidores se excusaron; los inquisidores también atacaron algunas fuentes utilizadas por Viera, como la Semi-historia del padre Mathías Sánchez (2008) y el Informe instructivo del arcediano José Marcos Verdugo y Alviturría.

Sin embargo, las solicitudes del Santo Oficio de Canarias para que se expurgase la obra de Viera obtuvieron por respuesta un lacónico "enterado" y que se tomarían las medidas oportunas; la Suprema ordenó que fueran enviadas al tribunal de la Corte una copia del libro para que fuera calificado y censurado, pero el tribunal madrileño incumplió la petición. De cualquier modo, podemos observar que las quejas no se dirigen al liberalismo de la interpretación histórica, sino únicamente tienen que ver con las aspectos que desprestigiaban al Santo Oficio con la ironía de Viera, máxime teniendo en cuenta que la primera carta de la Inquisición de Canarias a la Suprema acerca de la Historia de Viera y Clavijo está fechada el 18 de septiembre de 1784, y la segunda misiva fue del 7 de febrero de 1792, es decir, en una coyuntura de ataques al Tribunal de la Fe (ANAYA 1997, p. 173-182). ${ }^{10}$ Los inquisidores buscaban el momento de intervenir contra los menos ortodoxos, pero eran conscientes de que su contraataque rozaría las fronteras del obispado, por ello se limitaron a mandar informes al Consejo Supremo.

Probablemente debido al miedo al proceso revolucionario que se vivía en Francia, en 1791 las clases de Historia fueron suspendidas, y el 24 de febrero se ordenó la suspensión de todas las publicaciones privadas españolas quedando sólo la prensa oficial. Es decir, que se restringió la libertad de pensamiento y se actuó contra los exponentes de la Ilustración.

\section{Filosofía de Viera}

En el prólogo al primer tomo a pesar de reconocer que pretende "promover los verdaderos intereses de las Canarias", afirma que pretende ser una pluma "hábil e imparcial", pero los historiadores no pueden ni deben tener una capacidad imparcial, puesto que no podemos ser neutrales, sino que el producto historiográfico depende del interlocutor que nos cuenta la Historia. Diferenciamos completamente la imparcialidad de la objetividad, no podemos ni debemos ser imparciales, eso podría ser éticamente reprochable, siempre tomamos partido por unos o por otros, en nuestro caso por los más desfavorecidos, pero sí debemos ser objetivos en seguir una metodología y el respeto absoluto a las fuentes. Por tanto, es inaceptable la idea posmoderna ampliamente extendida qué mantiene que no existe la verdad histórica, sino distintas versiones de la historia, todas ellas iguales de legítimas. Creemos que el dato histórico ocurrido fue objetivo y nos aproximamos más o menos en función de la metodología utilizada y las fuentes.

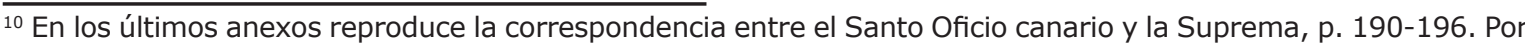
otra parte, DOMERGUE (1984) recoge los libros autorizados y prohibidos por la censura. Examina la forma en que el Santo Oficio dirige la lucha contrarrevolucionaria en el dominio ideológico. En concreto para Canarias tenemos el trabajo de DÍAZ (1989-1990, p. 67-72)
} 
Viera y Clavijo se educó en la filosofía escolástica, pero pronto la desechó. Pensaba que todo debía ser transparente a la razón y, nada debía ser aceptado de forma acrítica, es decir, que todo lo que se cree cierto, pudiera no serlo. Hizo carrera eclesiástica y al mismo tiempo, fue influido por la doctrina racionalista. Se dedicó a la historia con constancia, superando sus limitaciones.

En el pensamiento ilustrado tuvo un importante peso el pirronismo histórico, es decir, no creer con ligereza y saber dudar en muchas ocasiones, fruto de haber extendido la reflexión crítica al terreno de la historia, que no limitaba la discusión de la validez de las fuentes, sino que la aplicaba a los contenidos, hechos, ideas, valoraciones (FONTANA 1982, p. 62).

Podemos apreciar una doble influencia de Montaigne y Descartes, en Viera, escepticismo unido a fe ciega en las verdades personalmente comprobadas por el método silogístico. Aplica la crítica a la sociedad en que vive, la experiencia a la ciencia y el sentido común a la historia (CIORANESCU 1982, p. XXII; 1977, p. 188). La Historia le interesa como comprensión de la sociedad en la que vive, la que explica los progresos de la sociedad europea, desprecia la erudición y se acerca al hombre como sujeto de la sociedad. Viera no se basó únicamente en aspectos filosóficos, sino también sobre temas centrados en la vida cotidiana. La Historia occidental, la sucesión de los pueblos judío, griego y romano, envueltos por los bárbaros, es estimada, por tanto, como una de las posibles y no la única. Además, piensa que la historia debe servir para formar súbditos y proveer de modelos y ejemplos para el presente, por eso enjuicia y moraliza los acontecimientos que pertenecen a un pasado ajeno.

Muchas veces ha sido comparado con Voltaire, quizás nos parece excesivo, pero lo cierto es que pudo leerlo en la biblioteca de los marqueses de Villanueva del Prado y según afirmó el obispo Verdugo fue traductor suyo. En cuanto a la labor historiográfica, Voltaire trata de superar el marco de la historia política tradicional para construir la del espíritu humano. Situó a la Razón en el centro del pensamiento y además de teorizar sobre la historia, escribió varias obras propiamente historiográficas: El siglo de Luis XIV, Historia del Imperio Ruso bajo el reinado de Pedro el Grande y Ensayo sobre las costumbres y el espíritu de las naciones.

Viera ha sido considerado un personaje afrancesado volteriano, si no llegó a tanto, al menos hay que reconocerle su formación enciclopédica. Y sí que es cierto que mostró un interés preferente por la historia que estaban haciendo los franceses. Viera al igual que Voltaire dio importancia a los acontecimientos diplomáticos y militares, y en ambos casos hay una preocupación por perseguir documentos inéditos.

También la historiografía británica del siglo XVIII vio en el desarrollo histórico como una historia de la civilización. El análisis de cada época y de la evolución de cada pueblo, aparece en el contexto global del progreso hacia el conocimiento racional. Aquí destacaron especialmente David Hume, William Robertson y Edward Gibbon (SÁNCHEZ MARCOS 1988, p. 230-240), que probablemente fueron conocidos por Viera. 


\section{Nueva forma de hacer Historia}

Desde el punto de vista historiográfico es destacable la interpolación de material antropológico, histórico y cultural, donde expone contactos entre culturas diferentes en unas condiciones específicas, con una preocupación por el estudio de los grupos y etnias, sus creencias, sus instituciones y el funcionamiento de sus sociedades. También percibimos un creciente interés por el mundo vegetal y animal.

No tienen una intención deliberada de engañar distorsionando la realidad, pero presenta algunos fragmentos como reales, que, en verdad, responden a hechos imaginarios que él mismo creía que eran ciertos, de este modo, incluye algunos mitos y leyendas cuando falla la documentación. ${ }^{11}$

Tenemos varios ejemplos de la incorporación de estas historias fantásticas, que no tienen soporte en acontecimientos reales, une mitología e historia como el relato del príncipe Hércules, la muerte de Guillén Peraza o el cuento de Dácil y sus amores con Gonzalo García del Castillo que carecen de autenticidad, únicamente se basan en los amores cantados por el poeta Viana que los acepta como reales en su preocupación por la anécdota. La ficción toma protagonismo cuando presenta un suceso que es fabuloso como si fuese cierto (GALVÁN 1999). ${ }^{12}$

Presenta una cuidada redacción y un estilo literario destacado a la hora de escribir su Historia, sin renunciar a la dramatización, aunque desde la Inquisición se le critica acusándolo de galicista, de falta de rigor y de escaso ingenio, pero creemos que fue más motivado por un enfrentamiento corporativo que un hecho constatado. Su calidad literaria es innegable, con una prosa culta obtiene un texto ligero y ameno, pero ello no menoscaba su historicidad.

Antonio M. Bernal (1988) fue el primero que relacionó la obra de Viera con las crónicas americanas, pero creemos que es mayor el peso de los ilustrados franceses que de Bartolomé de Las Casas (1977) quien había publicado en 1552 en Sevilla toda una serie de tratados provocativos y la Brevísima Relación de la Destrucción de las Indias. Lo cierto es que es innegable esa relación con las crónicas indianas en las descripciones de obispos y generales, lejos de la tradición historiográfica del siglo XVIII, aunque con cierta distancia de las crónicas europeas anteriores de reyes y príncipes. Hay historias semejantes a las de grandes héroes en América, que denotan una relación con las gestas de los conquistadores en aquel continente. Igualmente, las comparaciones entre costumbres aborígenes con héroes de la épica griega.

Igualmente debemos destacar que su método crítico le lleva a dudar de cualquier autoridad y a realizar análisis de las fuentes. Antonio de Bethèncourt afirma que Viera conocía las técnicas de los documentalistas del siglo XVII de la escuela de Masillon, valoró la técnica sobre el análisis del contenido del documento, sin caer en el fetichismo de ese documento (BETHĖNCOURT 1991, p. 29).

${ }^{11}$ Vemos muchas de esas leyendas referidas a los primitivos canarios, contamos con una recopilación de todos esos mitos (GARCÍA Y GARCÍA DE LA TORRE 1969).

12 Esta es la publicación más extensa y más desarrollada de la obra historiográfica de Viera y el libro en su conjunto es, sin duda, el trabajo más riguroso hasta la fecha. 
También escribió algunas obras en versos en las que, sin intentar ser un tratado de historia, narran hechos pasados, y en ellas hay una visión implícita de la historia porque recurre a un suceso real y creíble, aunque suele mezclar la realidad con la ficción. En estos casos es aun, mayor el alejamiento de la realidad en esa poética histórica. Tomó inspiración en hechos históricos buscando gestas nacionales como la de Hernán Cortés o la toma de Granada por los Reyes Católicos en $1492 .{ }^{13}$ De este segundo hecho elaboró un romance heroico que presentó a un concurso poético convocado por la Real Academia de la Lengua Española en 1779. Se trata de un largo poema donde relata de forma superlativa la última batalla entre los andalucíes y los cristianos del norte (VIERA 2009, p. 38-54).14

En esta misma línea también cabe destacar El segundo agatocles o Cortés en la Nueva España, escrita también con motivo del concurso literario convocado por la Real Academia en 1778, para premiar el mejor poema épico sobre la figura de Hernán Cortés. Viera y Clavijo lo envió desde París, pero no fue galardonado. Este poema ha sido objeto de un estudio monográfico por parte de Victoria Galván (1991). El personaje central, el representante de la Corona castellana, no aparece inserto en su época, sino en el siglo XVIII, por tanto, favorable a Carlos V y su sucesor ahora, Carlos III. Además, Cortés está mitificado en su gesta por convertir infieles al cristianismo:

Recibiónos el jefe muy gozoso.

Es su nombre Cortés y que discreto

Bajo de un velo afable y majestuoso

Supo ocultar un corazón inquieto. ${ }^{15}$

El poema también centra su interés en los aborígenes, en este caso mexicanos, convirtiendo a Moctezuma en el segundo protagonista de la épica; no aparece como un gran rey, las costumbres indígenas son bárbaras con una religión cruel debido a que la fuente que utiliza son las crónicas de Hernán Cortés.

A su currículo como historiador debemos añadir que Viera y Clavijo fue miembro de la Academia de la Historia, primero como correspondiente y más tarde como supernumerario, recibiendo la medalla de oro. En su Oración gratulatoria de ingreso en la Real Academia de la Historia, manifestó su satisfacción por "estar escrito en la lista de aquellos hombres útiles, destinados a publicar las hazañas, grandezas, antigüedades y virtudes de la Nación", y llamó la atención sobre la falta de historiadores hispanos dejando el campo a extranjeros, junto con la necesidad de hacer una historia española de acuerdo a las nuevas concepciones investigadoras y metodológicas (MARTÍNEZ 1982, p. 34). ${ }^{16}$ También hizo de censor en diversas ocasiones, como parte de su actividad en esta institución. Justamente estuvo vinculado a la Academia de la Historia

\footnotetext{
${ }_{13}$ A.B.S/C.TFE, Sig: ms. 28 (2), manuscrito autógrafo, foliado a lápiz 24-39.

${ }^{14}$ La introducción (GALVÁN 2009, p. 12) hace referencia a esta poesía épico-heroica y patriótica así como a otros poemas que recrean acontecimientos de la historia local.

15 A.M.C. Fondo de Juan Padilla, Manuscritos, Volumen I, José Viera y Clavijo: Poesías, 1876, p. 9.

${ }^{16}$ El texto original de esta obra se conserva en A.R.S.E.A.P.TFE., Fondo Rodríguez Moure, Sig: 10/376, con edición de Las Palmas de Gran Canaria: Real Sociedad Económica de Amigos del País de Gran Canaria, 1807.
} 
en los años que andaba con el cuarto tomo, es decir, fines de los setenta y principios de los ochenta.

Además, en su trabajo como ayo del hijo del marqués de Santa Cruz se vio obligado a preparar un opúsculo de Historia, como Epítome de la Historia Romana, de la Historia de España y de la Historia eclesiástica, sin embargo, no podemos extraer ninguna información de esa obra dado que se puede considerar perdida (BLANCO 1981, p. 26).

Igualmente mantuvo actividades como documentalista, fue compilador de las actas de la Real Sociedad Económica de Amigos del País de Las Palmas desde su creación en 1777 hasta 1799, realizó el extracto de las actas del cabildo catedral de Canarias, recopilando toda la información desde 1514 a $1790^{17}$ y en 1793 fue nombrado por el Comandante General Antonio Gutiérrez, revisor real de los libros e impresos extranjeros que llegasen a la Aduana de Canarias (HORMIGA 2006, p. 34).

\section{Conclusiones}

La obra historiográfica de Viera y Clavijo fue la primera visión de conjunto de toda la Historia de Canarias en concordancia con las ideas ilustradas, que sin ser la más vanguardista en Europa, ni en España, sí que supuso un enorme paso adelante en el pensamiento canario. A pesar del poco reconocimiento alcanzado en su momento por su Historia General, tal como pronosticaba su coetáneo ilustrado Tomás de Nava-Gimón en una carta que le envía el 30 de agosto de 1772: "Aunque es cierto que este trabajo y gasto, será poco reconocido de pronto en nuestra Patria, también lo es que servirá para inmortalizar en ella el nombre de Vmd. Y hacerlo amable en el futuro".18

Sin duda alguna, Viera y Clavijo es el historiador más representativo de la Ilustración canaria y el más conocido de todos los tiempos. Existe una amplia bibliografía sobre sus obras, hemos podido localizar 182 trabajos de mayor o menor extensión, dedicados a este autor de forma monográfica, ${ }^{19}$ incluso hemos hallado alguno más.

La identidad canaria hoy en día es deudora de la obra de Viera y Clavijo, muchos de sus mitos e imaginarios arrancan de su Historia y, continúa moviéndose en esos cánones de la Ilustración canaria dieciochesca.

\footnotetext{
17 A.M.C. Extracto de las actas del Cabildo de la Diócesis de Canarias, 1514-1790, Por José de Viera y Clavijo, Copia de Agustín Millares Torres

${ }_{18}$ Cartas de Don Tomás Lino de Nava-Grimón Porlier, V marqués de Villanueva del Prado, desde La Laguna, a Don Joseph de Viera y Clavijo en Madrid. Transcripción, estudio preliminar y notas de Enrique Romeo Palazuelo, La Laguna: Instituto de Estudios Canarias, 1988, p. 44.

${ }^{19}$ Contamos con una muy buena recopilación en la base de datos bibliográfica de Canarias y el Atlántico dirigida por Antonio de Bethèncourt Massieu: www.canaratantico.org. En total suman 210 pero incluye las obras del propio José de Viera y Clavijo, algunos son trabajos periodísticos, pero otros son importantes estudios muy completos.
} 


\section{Referencias bibliográficas}

ÁLVAREZ MARTÍ-AGUILAR, Manuel. La Antigüedad en la historiografía española del siglo XVIII: el marqués de Valdeflores. Málaga: Universidad de Málaga, 1996.

ANAYA HERNÁNDEZ, Luis Alberto. Los problemas de Don Josef Viera y Clavijo con la iglesia y la inquisición canaria Anuario de Estudios Atlánticos, n. 43, p. 165-196, 1997.

ARENCIBIA, Yolanda. Tradición, Historia y Literatura: de Viera y Clavijo a Pérez Galdós. Las Palmas de Gran Canaria: Universidad de Las Palmas de Gran Canaria, Conferencia Inaugural del curso académico 1995-96, 1996.

ARIAS MARÍN DE CUBAS, Tomás. Historia de las siete islas de Canaria. Las Palmas de Gran Canaria: Real Sociedad Económica de Amigos del País de Gran Canaria, 1986.

BARRET-KRIEGEL, Blandine. La Défaite de I'érudition. Paris: PUF, 1998.

BERGASA PERDOMO, Óscar. José de Viera y Clavijo (1731-1813). La economía de su tiempo. Sus ideas y sus obras. Las Palmas de Gran Canaria: Real Sociedad Económica de Amigos del País de Gran Canaria, 2008.

BERNAL, Antonio M. Canarias y su historia: la obra singular de Viera y Clavijo. In: Serta Gratulatoria in honores Juan Régulo. La Laguna: Universidad de La Laguna, 1988. t. III, p. 257-265.

BETHENCOURT MASSIEU, Antonio de. Introducción. In: VIERA Y CLAVIJO, José de. Historia de Canarias. Islas Canarias: Gobierno de Canarias, 1991.

BLANCO MONTESDEOCA, Joaquín. Biografía de José de Viera y Clavijo. In: VIERA Y CLAVIJO, José de. Extracto de las actas de la Real Sociedad Económica de Amigos del País de Las Palmas (1777-1790). Las Palmas de Gran Canaria: Real Sociedad Económica de Amigos del País de Las Palmas, 1981.

CARBONELL, Charles-Olivier. L'historiographie. Paris: Presses Universitaires de France, 1981.

CASTRO ALFÍN, Demetrio. Viera y Clavijo y su historia. La continuidad de un género. In LAFORET, Juan José (Ed.). Estudios de historiografía regional. Jornadas en homenaje a Agustín Millares Torres. Las Palmas de Gran Canaria, Real Sociedad Económica de Amigos del País de Gran Canaria, 1996, p. 99-121.

CASTRO ALFÍN, Demetrio. Una vida sencilla y filosófica. El primitivismo idealizado en la Historia de Viera y Clavijo. In: Coloquio de Historia CanarioAmericana, XI. 1994. Las Palmas de Gran Canaria: Cabildo Insular de Gran Canaria, 1996. t. II, p. 703-725.

CASTRO ALFÍN, Demetrio. La historia imaginada, Viera y Clavijo, la 
monarquía y el pasado prehispánico de Canarias in Sociedad Española de Estudios del siglo XVIII. El mundo hispánico en el siglo de las luces. Madrid: Complutense, 1996. t. I, p. 575-585.

CEBRIÁN, José. Del epistolario de Viera y Clavijo y sus amigos de Viena. In: ÁLVAREZ BARRIENTOS, Joaquín; CHECA BELTRÁN, José (Ed.). El siglo que Ilaman Ilustrado. Madrid: Consejo Superior de Investigaciones Científicas, 1996, p. 209-220.

DEL CASTILLO, Pedro Agustín. Descripción histórica y geográphica de las Islas Canarias. Santa María de Guía: Disliber Santa María, 2008.

DÍAZ MARTÍN, Matías. Libros prohibidos en la Biblioteca del Seminario Conciliar de Canarias. Siglo XVIII. Parabiblos - Cuadernos de Biblioteconomía y Documentación, n. 3-4 p. 67-72, 1989-1990.

DOMERGUE, Lucienne. Le livre en Espagne au temps de la Révolution française. Lyon: Presses Universitaires de Lyon, 1984.

ELORZA, Antonio. El temido árbol de la libertad. In: AYMES, Jean-René (Ed.). España y la Revolución francesa. Barcelona: Crítica, 1989, p. 69-117.

ESPINOSA, Alonso de. Historia de Nuestra Señora de Candelaria. Santa Cruz de Tenerife: Goya, 1980.

ESTÉVEZ GONZÁLEZ, Fernando. Indigenismo, raza y evolución. EI pensamiento antropológico canario (1750-1900). Santa Cruz de Tenerife: Cabildo de Tenerife, 1987.

ESTÉVEZ GONZÁLEZ, Fernando. La invención del guanche. Clasificaciones imperiales y correlatos identitarios de la raciología en Canarias. In Fundación Canaria Orotava de Historia de la Ciencia (Ed.). Ciencia y cultura de Rousseau a Darwin. Canarias: Gobierno de Canarias, 2008.

FAJARDO SPÍNOLA, Francisco. Viera y Clavijo, historiador de Canarias. In GALVÁN GONZÁLEZ, Victoria. Viera al trasluz. Idea: Santa Cruz de Tenerife, 2009, p. 85-112.

GERBI, Antonello. La disputa del Nuevo Mundo. Historia de una polémica 1750-1900. México: Fondo de Cultura Económica, 1982.

FLORES, Enrique. España sagrada. Theatro geográfico histórico de la iglesia de España. Madrid: Antonio Martín, 1747-1777. 51 v.

FONTANA, Joseph. Historia. Análisis del pasado y proyecto social. Barcelona: Crítica, 1982.

GALVÁN GONZÁLEZ, Victoria. América en la obra de Viera y Clavijo: El segundo agatocles o Cortés en la Nueva España. In: Homenaje al profesor Sebastián de la Nuez. La Laguna: Universidad de La Laguna, 1991, p. 135-143.

GALVÁN GONZÁLEZ, Victoria. Los diarios de viaje de José de Viera y Clavijo 
(1731-1813). In: SOCIEDAD ESPAÑOLA DE ESTUDIOS DEL SIGLO XVIII. El mundo hispánico en el siglo de las luces. Madrid: Complutense, 1996. t. I, p. 655-668.

GALVÁN GONZÁLEZ, Victoria. La obra literaria de José de Viera y Clavijo. Las Palmas de Gran Canaria: Cabildo Insular de Gran Canaria, 1999.

GALVÁN GONZÁLEZ, Victoria. La ilustración en Canarias. In: ARENCIBIA, Yolanda; GALVÁN GONZÁLEZ, Victoria. Viera y Clavijo bajo el signo de la Ilustración. Las Palmas de Gran Canaria: Cabildo de Gran Canaria, 2013, p. 23-36.

GARCÍA DEL CASTILLO, Bartolomé. Antigüedades y ordenanzas de la isla de EI Hierro. Las Palmas de Gran Canaria: El Museo Canario-Cabildo de El Hierro, 2003.

GARCÍA Y GARCÍA DE LA TORRE, José Manuel. Leyendas guanches de las Islas Canarias. Barcelona: Artes Gráficas, 1969.

GONZÁLEZ MONTERO DE ESPINOSA, Marisa. La ilustración y el hombre americano. Descripciones etnológicas de la expedición de Malaspina. Madrid: Consejo Superior de Investigaciones Científicas. 1992.

HERNÁNDEZ GUTIÉRREZ, Sebastián. Josephus Viera y Clavijo, presbyter canariensis. Santa Cruz de Tenerife: Gobierno de Canarias-Ayuntamiento de los Realejos, 2006.

HOF, Ulrich Im. La Europa de la Ilustración. Crítica: Barcelona, 1993.

HORMIGA, Félix. Noticias de José de Viera y Clavijo. Canarias: Gobierno de Canarias, 2006.

KANT, Immanuel. Rencensiones sobre la obra de Herder "Ideas para una Filosofía de la Historia de la Humanidad. In: KANT, Immanuel. Ideas para una historia universal en la clave cosmopolita y otros escritos sobre Filosofía de la Historia. Madrid: Tecnos, 1987.

LAFORET, Juan José. Orígenes de la imprenta en la provincia de Las Palmas. Las Palmas de Gran Canaria: Asociación de Empresarios de la Imprenta y Artes Gráficas de la provincia de Las Palmas, 1991.

LAS CASAS, Bartolomé de. Brevísima Relación de la Destrucción de las Indias. Madrid: Fundación Universitaria Española, 1977.

LUXAN Y MELÉNDEZ, Santiago de. Ensayo de una biblioteca ilustrada. La librería virtual de Viera y Clavijo. Las Palmas de Gran Canaria: Real Sociedad Económica de Amigos del País de Gran Canaria, 2007.

MARTÍNEZ SÁNCHEZ, Juan José. La historiografía en tiempos de Viera. In: VIERA Y CLAVIJO, Joseph de. Librito de la doctrina rural, para que se aficionen los jóvenes al estudio de la agricultura propia del hombre. Santa Cruz de Tenerife: Nicolás González Lemus, 1982, p. 21-35.

MASDEU, Juan Francisco. Historia crítica de España y de la cultura 
española en todo género. Madrid: Don Antonio de Sancha, 1783-1805. $20 \mathrm{v}$.

MESTRE, Antonio. El mundo intelectual de Mayans. Artes Gráficas Soler: Valencia, 1978.

MESTRE, Antonio. Mayans y la España de la Ilustración. Espasa-Calpe: Madrid, 1990.

MESTRE, Antonio. La historiografía española en el siglo XVIII. In: Coloquio Internacional Carlos III y su siglo. Madrid: Universidad Complutense, 1990, p. 21-60. v. I.

MESTRE, Antonio. Don Gregorio Mayans y Siscar, entre la erudición y la política. Alfons el Magnanim: Valencia, 1999.

MESTRE, Antonio. Mayans y Siscar y el pensamiento ilustrado español contra el absolutismo. Universidad de León: León, 2007.

MOHEDANO, Rafael; RODRÍGUEZ, Pedro. Historia literaria de España, desde su primera población hasta nuestros días. Madrid: Imprenta de Francisco Xavier García, 1766-1791. 12 v.

NEGRÍN FAJARDO, Olegario. José Viera y Clavijo: El Síndico Personero general. Obra patriótica escrita periódicamente en la ciudad de La Laguna. Las Palmas de Gran Canaria: Cabildo Insular de Gran Canaria, 1994.

NÚÑEZ DE LA PEÑA, Juan. Conquistas y antigüedades de las islas de la Gran Canaria y su descripción, con muchas advertencias de sus privilegios, conquistadores, pobladores y otras particularidades en la muy poderosa isla de Thenerife. La Coruña: Orbigo, 2008.

PALENZUELA BORGES, Nilo. Viera y Clavijo, entre las dos orillas. El Día, p. 33, 27 dec. 1981.

PASAMAR, Gonzalo. Apologia and Criticism. Historianas and the History of Spain, 1500-2000. Peter Lang: Oxford, 2010.

RÉGULO PÉREZ, Juan. La historiografía canaria después de Viera y Clavijo. In: NUEZ CABALLERO, Sebastián de la. Noticias de la historia de Canarias. Cupsa: Madrid, 1981. v. III, p. 90.

ROMEU PALAZUELO, Enrique. Biografía de Viera y Clavijo a través de sus obras. Santa Cruz de Tenerife: Cabildo Insular de Tenerife, 1981.

SÁNCHEZ, Mathías. Semi-historia de las Fundaciones, Residencias, o Colegios que tiene la Compañía de Jesús en las Islas Canarias. La Laguna, Instituto de Estudios Canarios, 2008.

SÁNCHEZ MARCOS, Fernando. Invitación a la Historia. De Heródoto a Voltaire. Barcelona: PPU, 1988.

SÁNCHEZ MARCOS, Fernando. La historiografía sobre la Edad Moderna. In: ANDRÉS-GALLEGO, José (Ed.). Historia de la historiografía española. 
Madrid: Encuentro Ediciones, 2003, p. 135-136.

SÁNCHEZ RODFRÍGUEZ, Julio. José de Viera y Clavijo. Sacerdote y Arcediano. Las Palmas de Gran Canaria: JSP, 2007.

SANTANA PÉREZ, Juan Manuel. Historiografía canaria sobre el Antiguo Régimen. Almogaren, v. XXX, p. 117-130.

SOSA, José de. Topografía de la isla afortunada Gran Canaria cabeza del partido de toda la provincia comprensiva de las siete islas llamadas vulgarmente afortunadas. Su antiguedad, conquista é invasiones; sus puertos, playas, murallas y castillos; con cierta relación de sus defensas / escrita en la M.N. y muy leal ciudad Real de Las Palmas, por un hijo suyo el M.R.P. Fr. José de Sosa. Santa Cruz de Tenerife: Imprenta Isleña, 1849.

VIANA Antonio de. Antigüedades de las islas Afortunadas. La Laguna: Ayuntamiento San Cristóbal de La Laguna, 1996.

VIERA Y CLAVIJO, José de. Cartas de Don José de Viera y Clavijo a diversas personalidades. Santa Cruz de Tenerife: Goya, 1984.

VIERA Y CLAVIJO, Joseph de. Noticias de la Historia General de las Islas Canarias. Canarias: Gobierno de Canarias, 2004.

VIERA Y CLAVIJO, José. Antología poética. Santa Cruz de Tenerife: Idea, 2009.

VOLTAIRE. El siglo de Luis XIV. México: Fondo de Cultura Económica, 1978.

WULFF Fernando. Las esencias patrias. Historiografía e Historia Antigua en la construcción de la identidad española (siglos XVI-XX). Barcelona: Crítica, 2003. 


\title{
A normatização disciplinar da historiografia universitária: Francisco Iglésias e a sua tese de Livre- Docência* $^{*}$
}

\author{
The disciplinary norming of the university historiography: Francisco \\ Iglésias and his Academic Thesis
}

\author{
Alessandra Soares Santos \\ alessandrast@ufmg.br \\ Professora efetiva \\ Universidade Federal de Minas Gerais \\ Rua Tenente Garro, 627, ap. 301 - Santa Efigênia \\ 30240-360 - Belo Horizonte - Minas Gerais \\ Brasil
}

\section{Resumo}

A redefinição dos códigos disciplinares da pesquisa histórica pelos primeiros historiadores oriundos das universidades brasileiras não ocorreu por meio de nenhuma revolução ou mudança rápida de paradigma. Assim, os indícios da construção de novas maneiras de fazer e pensar a história devem ser localizados na forma como se concebeu cada empreendimento de escrita específico. Analisamos neste artigo o potencial discursivo e a recepção da tese de livre-docência de Francisco Iglésias e de seus primeiros textos publicados a partir de sua efetivação como docente, na década de 1950, para afirmar e produzir uma reorganização disciplinar do conhecimento histórico produzido na universidade. Consideramos que a vinculação institucional de seu texto não foi um procedimento puramente formal: foi a partir da universidade que ele justificou sua escolha temática e diferenciou sua escrita de outras produções historiográficas.

\section{Palavras-chave}

Historiografia brasileira; Conhecimento histórico; Francisco Iglésias.

\section{Abstract}

A disciplinary code of a history research was redefined by the first historians graduated in Brazilians universities. But it didn't happen like a revolution or a radical paradigm change. Thus, the new ways to make history e think about the discipline must be connected with the different ways to write a history text. That paper aims to analyze the Francisco Iglésias thoughts about history knowledge, the discursive potential and the reception of his academic thesis, as well as his first papers published in the 1950 's, to confirm and produce a disciplinary reorganization made by professional historians, in the universities. We consider that the institutional bonds manifested on his texts weren't just a formal procedure, but a deliberated way to distinguish from others history texts produced in that time.

\section{Keywords}

Brazilian historiography; Historical knowledge; Francisco Iglésias.

Recebido em: 21/10/2016

Aprovado em: 9/3/2017

*Pesquisa financiada pela CAPES. 
A identidade da história e do historiador, que, no Brasil, desde o século XIX eram privilegiadamente constituídas no interior dos institutos históricos e geográficos, ganhou um novo lugar de gestação a partir das décadas de 1930 e 1940 com a ampliação do ensino superior e a institucionalização dos cursos de História. A essa mudança, contudo, não correspondeu de imediato uma alteração substancial nas técnicas, nos métodos de investigação e no levantamento de novas questões e hipóteses sobre o passado, pois a condução do conhecimento histórico para dentro da universidade brasileira resultou na assimilação de técnicas da ciência histórica que foram desenvolvidas fora dela.

Não se trata, portanto, de perguntarmos qual o impacto da institucionalização universitária do saber histórico sobre a historiografia brasileira, nem de questionarmos até que ponto esta reorganização social rompeu com uma tradição historiográfica e impôs outra; afinal, não estamos diante de nenhum evento fundador. As transformações internas e externas ao discurso histórico não atendem aos mitos de uma constituição progressiva da historiografia, configurado por suas relações com o sistema no qual é elaborado e em contextos específicos. Partimos do pressuposto de Certeau (2008) de que toda pesquisa se articula com um lugar de produção socioeconômico, político e cultural, com uma "instituição do saber" que condiciona uma linguagem científica. Daí emerge o seu valor documental e a contribuição das obras históricas do passado para o conhecimento da própria história.

Por outro lado, é preciso considerar também que houve uma importante reconfiguração da função social do historiador a partir de sua inclusão no universo do ensino superior e da construção da ideia da "universidade moderna", o que impôs a transformação da maneira como os historiadores justificavam o seu próprio trabalho diante daqueles que não possuíam uma formação específica. Assim, não se pode dizer que as circunstâncias sociais que permitiram a emergência desse novo lugar de produção da historiografia não estivessem em estreita relação com uma modificação discursiva dos parâmetros disciplinares do saber histórico. Os indícios desta redefinição podem ser localizados na forma como se concebe cada empreendimento de escrita específico, já que é a partir da identificação das normas que traduzem as exigências disciplinares em determinados contextos - os objetos históricos considerados legítimos, a estruturação do texto, a afirmação de conceitos, as citações, os diálogos teóricos - que podemos perceber as mudanças efetuadas no conhecimento a partir dos impulsos de um novo lugar de produção da história, bem como a permanência de ideias e práticas alheias à afirmação do modelo.

Embora essa disciplinarização esteja desvinculada de qualquer proposição autoral, suas regras são constantemente reatualizadas por uma corporação discursiva de sujeitos específicos que garantem o advento e a manutenção de seus princípios através das escolhas concretas que realizam. Ao mesmo tempo em que obedece a regras próprias, a disciplina se articula aos enunciados individuais que escapam do anonimato e arrogam para si a função de preservá-la (FOUCAULT 2003). Acreditamos que o historiador Francisco Iglésias (1923-1999) foi um destes agentes que contribuíram para dar uma 
feição própria à historiografia produzida na universidade, pois, para participar de seu ordenamento discursivo, ele não só satisfez todas as exigências para ter acesso a certo número de regras do ofício, como parece ter se qualificado para atualizá-las.

Formado na segunda turma do curso de Geografia e História da Universidade de Minas Gerais em 1945, Francisco Iglésias ingressou como professor da Faculdade de Ciências Econômicas em 1949 e defendeu sua tese de livre docência em 1955. Autor de inúmeros livros, artigos, prefácios, comentários e relatórios técnicos; participante de incontáveis bancas de concursos públicos, defesas de teses e monografias e membro de conselhos editoriais de revistas acadêmicas, ele não só se submeteu como participou da construção dos critérios disciplinares da historiografia universitárias desde a sua institucionalização.

Analisamos aqui o potencial discursivo da tese de livre-docência de Francisco Iglésias e de seus primeiros textos publicados a partir de sua efetivação como docente, na década de 1950, para afirmar e produzir uma reorganização disciplinar do conhecimento histórico produzido na universidade. A partir da recuperação dessas reflexões identificamos uma postura teórica estreitamente relacionada ao anseio por uma metodologia histórica própria ao empreendimento científico universitário.

\section{Incorporando uma codificação}

Ao ingressar como professor na Faculdade de Ciências Econômicas da UFMG, Francisco Iglésias incorporou uma codificação que, para além de representar sua inserção na prática formal do discurso acadêmico, alterou o próprio conteúdo daquilo que estava sendo dito. Tal movimento pode ser percebido pela análise da tese de livre-docência apresentada por ele em 1955 e publicada em 1958 como Política econômica do governo provincial mineiro (1835-1889), e do livro Introdução à historiografia econômica, publicado em 1959 - suas primeiras realizações historiográficas a partir da universidade.

Francisco Iglésias começou a escrever sua tese de livre-docência em 1953, motivado pela vontade de permanecer como professor da Faculdade de Ciências Econômicas. ${ }^{1}$ Ele ocupava o cargo de assistente de ensino desde 1949, mas, de acordo com o Regulamento da Assistência de Ensino, aprovado em 1951, ele só poderia permanecer na função por até quatro anos. ${ }^{2}$ Após esse período, o assistente deveria se submeter ao concurso de livre-docência, passando a professor adjunto. ${ }^{3}$ O concurso foi realizado em 1955, tendo como comissão julgadora os professores Alice Piffer Canabrava, Emílio Guimarães Moura, Hélio

\footnotetext{
${ }^{1}$ Embora Francisco Iglésias tenha iniciado sua carreira na Faculdade de Ciências Econômicas da UFMG lecionando Geografia Econômica, logo foi convidado pelo catedrático de História Econômica, Rodolfo de Abreu Bhering, para assisti-lo nesta cadeira.

${ }^{2}$ Como assistente de ensino, Francisco Iglésias lecionou as disciplinas Geografia Histórica, Geografia Econômica e História do Brasil para o curso preparatório de candidatos ao concurso de habilitação da Faculdade de Ciências Econômicas, também chamado de curso pré-vestibular ou curso anexo, entre 1951 e 1954 . De 1956 até 1958, já concursado, ele lecionou para os cursos de Política e Sociologia e de Administração Pública as disciplinas História da Economia, História Social e Política do Brasil e História Econômica Geral e do Brasil.

${ }^{3}$ Regulamento da Assistência de Ensino aprovado pela Congregação da Faculdade de Ciências Econômicas em 16 de março de 1951.
} 
Viana, Raul Jobim Bittencourt e Rodolfo de Abreu Bhering. Sua tese foi publicada pelo Instituto Nacional do Livro em 1958 e é esta a edição que usamos aqui.

Embora já tivesse publicado inúmeros artigos e resenhas em revistas acadêmicas, a tese de livre-docência pode ser considerada a obra de estreia de Francisco Iglésias na universidade. Em termos de esforço investigativo e tempo despendido, ele fez desse trabalho inaugural um produto exemplar do lugar de produção científica que a universidade representava. De acordo com sua explicação inicial, o que o teria levado ao assunto da política econômica da província mineira seria "a preocupação com a realidade de Minas e o nosso conceito de tese e de trabalho universitário", visto que, na sua concepção, para realizar um estudo desse tipo, o historiador precisaria ter consciência dos limites impostos pela pesquisa científica, escolhendo temas cuja documentação pudesse ser encontrada com relativa facilidade (IGLÉSIAS 1958, p. 9-11).

A vinculação institucional de seu texto, portanto, não foi um procedimento puramente formal: foi a partir da universidade que ele justificou sua escolha temática e diferenciou sua escrita de outras produções historiográficas. Daí ele ter inaugurado em seu primeiro empreendimento acadêmico uma prática que se tornou comum em suas obras: o exercício de autolocalização da sua contribuição intelectual. A recorrência desta maneira de apresentar seus trabalhos revelava a sobrevivência de uma preocupação com a legitimação da produção da historiografia universitária confiada no cumprimento dos objetivos da própria universidade. Tal esforço tinha a pretensão de definir a realização de seus estudos em função da relação que eles mantinham com outros trabalhos e com as problemáticas exploradas pelo grupo de pesquisadores da comunidade científica.

A convicção de Francisco Iglésias de que a historiografia universitária deveria contribuir para a ampliação do conhecimento oferecendo um ponto de vista original sobre determinado assunto levou-o ao século XIX, pois ele constatou que "a vida provincial mineira quase ainda não existe como tema para o historiador. À vista de tal verificação, animou-nos a ideia de que qualquer esforço teria sentido" (IGLÉSIAS 1958, p. 11). A ausência de bibliografia para a fase provincialfaria todo e qualquer empreendimento ser inédito, realizando de forma mais estreita o propósito suposto da universidade, que era "contribuir mais efetivamente para o conhecimento do país" (IGLÉSIAS 1958, p. 14). De acordo com Iglésias, este objetivo deveria ser traduzido não somente pela divulgação do que já era conhecido, mas, sobretudo, pelo esforço de produzir conhecimento original. Sua avaliação era a de que "em países como o nosso, mais talvez que em outros, esse é um dever, pois há ignorância generalizada das suas coisas, enquanto o esforço intelectual, por falta de tradição ou apoio, ainda é apenas teimosia de obstinados" (IGLÉSIAS 1958, p. 14-15).

A escrita de Francisco Iglésias elaborada até então, cujos textos preencheram as páginas de jornais e revistas, estava restrita ao cumprimento daquela primeira tarefa. Embora ele tenha valorizado a história de Minas Gerais por meio da publicação de resenhas de obras de viajantes que passaram pelo estado, como John Mawe, e de historiadores, como Diogo de Vasconcelos, sua contribuição ainda não tinha ido além dos limites da difusão do conhecimento existente. $E$ 
esse conhecimento, segundo sua observação em um artigo publicado em 1949, era extremamente insatisfatório, pois não ultrapassava a fase do arrolamento de nomes e datas, e que "a história mineira tem sido mais uma crônica do que história propriamente":

O estudo das coisas mineiras bem poucas vezes se tem chegado à História [...]. Para que haja história, como diz o lugar comum, é preciso que haja interpretação. No mais, temos apenas grossos relatórios que ainda não foram trabalhados pelo espírito crítico característico do historiador: temos a matéria bruta com a qual se faz a história, mas não a história propriamente. $O$ estudioso que não dá um passo além dessa primeira fase não merece ser chamado historiador; cabem-lhe melhor outros epítetos (IGLÉSIAS 1949, p. 1).

Quando Francisco Iglésias escolheu o tema de sua tese, preocupava-o cumprir as exigências de um trabalho universitário sob o ponto de vista da viabilidade científica e da originalidade, daí ter escolhido um tema próximo Minas Gerais - e pouco examinado - a vida provincial. Como postulante de cargo no ensino superior, sua tese guardou as marcas deste "rito iniciático" na abundância de notas e na presença de bibliografia crítica. Às notas de referência foram juntadas outras, mais esparsas, para discutir os trabalhos de outros historiadores, norma que se estendeu ao conjunto da produção histórica universitária. ${ }^{4}$ De fato, segundo Grafton, a história das notas de rodapé pode mostrar as mutações que a narrativa histórica sofreu ao longo dos séculos em decorrência das lutas por poder institucional (GRAFTON 1998, p. 189). Mas, como a presença delas não é suficiente para garantir a cientificidade do texto, daí decorre a necessidade de dar significado a outras demarcações que podem ajudar a esclarecer os postulados epistemológicos da historiografia universitária.

De acordo com Delacroix, Dosse e Garcia (2012, p. 91), o novo modo de escrever história imposto à universidade afetou o estilo dos historiadores, "que são convidados a romper com a retórica e dar a seus trabalhos [...] o tom desenvolto e austero da ciência" Nesse sentido, Francisco Iglésias organizou seu espaço textual de acordo com a organização do espaço social no seu entorno. Como observou Certeau, a historiografia produz sua credibilidade através da linguagem referencial que tem por função comprovar o discurso: as citações e notas produzem um "efeito de real" e remetem a um "lugar de autoridade". A aparente comprovação de seus enunciados, portanto, se baseia no ato da palavra como ato de autoridade. Para além dos dispositivos de produção de credibilidade, a linguagem referencial da historiografia ajuda a demarcar o espaço no qual sua "encenação escriturária" ganha sentido, pois "citando, o discurso transforma o citado em fonte de credibilidade e léxico de um saber" (CERTEAU 2008, p. 102). A relação entre o lugar deste saber e sua exterioridade se faz presente na própria interpretação que é oferecida ao leitor: 
[...] o discurso produz um contrato enunciativo entre o remetente e o destinatário. Funciona como discurso didático, e o faz tanto melhor na medida em que dissimule o lugar de onde fala (ele suprime o eu do autor), ou se apresente sob a forma de uma linguagem referencial (é o "real" que Ihes fala), ou conte mais do que raciocine (não se discute um relato) e na medida em que tome os seus leitores lá onde estão (ele fala sua língua, ainda que de outra maneira e melhor do que eles) [...] Este discurso não deixa escapatória. A estrutura interna do discurso trapaceia. Produz um tipo de leitor: um destinatário citado, identificado e doutrinado pelo próprio fato de estar colocado na situação da crônica diante de um saber (CERTEAU 2008, p. 102-103).

Mas, ao precisar alguns aspectos de sua construção historiográfica sua motivação, suas escolhas conceituais e temáticas -, Francisco Iglésias confrontou a imposição do discurso histórico de se situar fora da experiência que Ihe confere crédito. Ele mostrou que sua escrita histórica estava controlada pelas práticas das quais era resultado, sendo ela própria uma prática social vinculada a uma instituição supostamente mais legítima. Antes de fixar como início da sua narrativa aquilo que, na realidade, era um ponto de chegada da pesquisa histórica - um dos aspectos que caracterizam a passagem da prática investigadora à escrita e que Certeau chamou de "inversão escriturária" -, Iglésias conduziu seu leitor ao lugar de onde falava.

A institucionalização universitária do conhecimento histórico estava provocando nos agentes que dela participavam uma tentativa de reconstrução da identidade disciplinar da história, do historiador e de sua legitimidade científica, daí a pertinência dessa estratégia. Ainda que Iglésias tenha manifestado o reconhecimento do valor das contribuições que foram dadas por vários autores mineiros, ele não reconheceu a cientificidade nos empreendimentos historiográficos anteriores, acusando-os de reforçarem mitos e fantasias ao invés de esclarecerem a realidade; mais que isso, foi em oposição a este modelo que procurou afirmar o horizonte científico da sua tese. Seu papel deveria ser "colocar o assunto no domínio da pesquisa e das noções objetivas, pondo de lado o saudosismo romântico e ingênuo" (IGLÉSIAS 1958, p. 10). A crítica ao "amadorismo" das produções históricas sobre Minas Gerais já tinha aparecido em um artigo de 1952, no qual afirmava que:

A história de Minas, para nós pouco mais tem sido que lembrança orgulhosa acompanhada de suspiros. Se esse estado de espírito pode ser compreensível em pessoas que perderam o que tinham e vivem em cidades mais antigas, entre restos de um passado superior ao presente é de todo injustificável fora dos quadros de uma lamentação aborrecida que resulta de uma condição mórbida que não tem sequer o encanto de certas correntes de pensamento tradicionalista romântico (IGLÉSIAS 1952).

Com a expectativa de uma mudança evolutiva, Francisco Iglésias classificou o conhecimento histórico sobre Minas Gerais como em "estado rudimentar" e atribuiu esta condição a dois fatores: a falta de formação da maioria dos estudiosos e a prudência excessiva que os impediria de avançar nas interpretações (IGLÉSIAS 1949, p. 1). Daí ele ter esclarecido em sua tese 
que buscou compreender a realidade de Minas Gerais no século XIX com as ferramentas que este novo lugar de produção de conhecimento - a universidade - poderia oferecer, ou seja, "com a objetivação de problemas fundamentais e com a adoção de métodos e técnicas adequados" (IGLÉSIAS 1958, p. 9). O que postulava, portanto, era a adoção de uma nova atitude cognitiva, uma ruptura epistêmica com o que ele considerava fazer parte do senso comum e da ideologia graças à produção de uma história problematizadora em lugar da simples reprodução de fatos cuja existência era supostamente irredutível.

Se as possibilidades da escrita da história nestes termos estavam sendo reivindicadas, como é sabido, por outros historiadores desde a década de 1930, vale ressaltar que Francisco Iglésias contribuiu para a articulação desta história "nova" ao meio universitário brasileiro como condição indispensável para a sua realização. Antes dos anos 1960 e 1970, quando emergiram os primeiros cursos de pós-graduação em História, já havia um esforço para deslocar a produção historiográfica dos lugares institucionais considerados tradicionais ou aristocráticos (IHGB, ABL, ISEB e etc.) para a universidade, que, pelo menos no contexto mineiro, já dava oportunidade para que discentes e docentes sem vínculos com as elites tradicionais nela ingressassem, como era o caso do próprio Iglésias.

A inspiração historiográfica declarada de Francisco Iglésias foi a obra do economista e historiador sueco Eli F. Heckscher sobre a época mercantilista, o qual se deteve nos planejamentos políticos que influíram no desenvolvimento econômico e não no próprio desenvolvimento econômico (HECKSCHER 1943). Daí Iglésias ter também recortado seu objeto para esclarecer a política econômica, e não os fenômenos econômicos. A consciência de que a análise da política econômica realizada durante todo o Império seria inviável nos limites de uma tese o levou a delimitar cronologicamente seu trabalho entre 1835 e 1889, da Reforma da Constituição à Proclamação da República. No caso do marco inicial, porque foi a partir de 1835 que as províncias passaram a dispor de um governo, de um legislativo próprio e de uma relativa autonomia; quanto ao final, embora tenha reconhecido que os limites adotados seriam antes políticos que econômicos, argumentou que a data teria muito sentido econômico, uma vez que deu início a uma nova estrutura do país, com a substituição do trabalho escravo pelo trabalho livre.

A lógica da ordem temporal presente em sua tese poderia ser classificada, de acordo com o esquema de Norma Côrtes para a geração nacionalista da década de 1950, como uma razão dual: a realidade nacional encerraria uma simultaneidade de diversas fases históricas. Essa noção de "contemporaneidade do não coetâneo", tributária de Ortega y Gasset, rejeita a temporalidade linear e postula a sincronicidade, de forma que "novo e velho, moderno e atraso, atual e inatual, esperanças (projetos de futuro) e ultrapassados (memória e tradição) sempre coexistem em um mesmo momento presente" (CÔRTES 2008, p. 239). Francisco Iglésias percebeu essa temporalidade múltipla, conflitiva e ambígua quando afirmou que: 
[...] entre nós qualquer alteração pequena exige muitos anos: o desenvolvimento não se faz com harmonia - enquanto em certos pontos a estrutura se altera, torna-se complexa ou rica com elementos novos, em outros a estática é a única lei, de modo que vivem agora como viviam no Império, às vezes até com traços mais antigos. Para uma realidade mais profunda, como é a econômica, os fatos políticos quase não contam, as datas não têm sentido. As adaptações são lentas, de modo que mal se percebe que houve mudança de aspecto, tão imperceptível foi a evolução (IGLÉSIAS 1958, p. 13-14).

Pleiteando a cadeira de História Econômica, a tese de Francisco Iglésias se enquadrava nos limites dessa história especial. As histórias especializadas estavam sendo percebidas por ele naquele momento como uma conquista fundamental da "historiografia moderna", na qual ele se esforçava por se autoposicionar. Sua reflexão a esse respeito apareceu no livro Introdução à historiografia econômica, publicado, como visto, em 1959.

Francisco Iglésias rechaçou aí a historiografia romântica do século XVIII e valorizou o esforço de exatidão e ampliação do conteúdo feito no século XIX pela escola metódica. Ele atribuiu a esse momento a diversificação da história, que não deveria ser somente política, mas política, social, religiosa e econômica ao mesmo tempo (IGLÉSIAS 1959). Francisco Iglésias ainda não havia se rendido à crítica dos Annales à história produzida no século XIX e, por isso, ele foi capaz não só de reconhecer o esforço metódico e crítico dos historiadores do XIX, mas também de ressaltar que a história produzida então não era somente política.

A primeira parte de sua tese, intitulada "A realidade política", tratou justamente dos elementos que teriam dado unidade ao Império e que tiveram consequências para a efetivação das políticas por ele implantadas. Somente na segunda parte, intitulada "Política econômica do governo provincial mineiro", é que ele abordou a política econômica propriamente dita. A lavoura, a pecuária, a indústria, a mão de obra, o ensino técnico, o transporte e as finanças foram os elementos que, segundo Francisco Iglésias, caracterizaram a política econômica provincial de Minas Gerais. A cada um deles, o autor dedicou um estudo específico.

\section{A legitimação da historiografia econômica}

Em Introdução à historiografia econômica, ele apresentou uma reflexão teórica que acabou legitimando o esforço em torno da história da política econômica do governo provincial mineiro realizado em sua tese. Os dois textos foram elaborados quase simultaneamente, o que justifica a análise que os toma como complementares. Comparando os temas abordados no livro com os assuntos lançados nos diários de classe das aulas de História da Economia ministradas por ele em 1956 e 1958 para os cursos de Sociologia e Política e de Administração Pública na Faculdade de Ciências Econômicas da UFMG, é possível concluir que esta obra foi resultado das aulas que ele preparava para lecionar a matéria. ${ }^{5}$ Um artigo publicado na Revista da Faculdade de Ciências

\footnotetext{
${ }^{5}$ Diário de Classe e Relação Geral do Ano. Aula de História da Economia do $3^{\circ}$ ano, turma única. Professor
} 
Econômicas, em 1954, também foi aproveitado no livro. Seu interesse não foi discutir a problemática dos processos da vida econômica através dos tempos, mas os problemas metodológicos que explicam "como é que se chegou, entre os historiadores, à colocação do econômico entre suas preocupações, a ponto de desenvolver um ramo especial de seus estudos" (IGLÉSIAS 1959, p. 12).

Depois de situar o leitor no conceito de história econômica e na posição do econômico na historiografia, ele tratou da Escola Histórica de Economia Política desenvolvida na Alemanha durante o século XIX e sua contribuição para a interpretação econômica da história, sobretudo a partir de Karl Marx. Em seguida, estudou a historiografia econômica brasileira, na qual destacou as obras de José Honório Rodrigues, Celso Furtado, Caio Prado Júnior e Roberto Simonsen. Seu livro foi alvo da crítica de Nelson Werneck Sodré, que apontou a ausência de fundamento científico na escolha das fontes pelo autor:

A súmula de Francisco Iglésias sobre historiografia econômica, em que observações pertinentes e acertadas, parece-nos deficiente nas suas fontes. O exame crítico dessas fontes revela um apreço injustificado por algumas a que falta qualquer fundamento científico. No exame das fontes, particularmente quanto crítico, deve antes de tudo, existir uma escala: mais vale selecionar os títulos adequados, definindo as tendências e os métodos a que obedecem, do que proceder a um arrolamento. Em cultura, omitir e esquecer, tem também uma função (SODRÉ 1959, p. 9-11).

A crítica do historiador marxista, autor de uma obra engajada e que foi considerada uma das mais representativas das diretrizes interpretativas do Partido Comunista Brasileiro, era justificada. Em Introdução à historiografia econômica Francisco Iglésias primou pela "sobriedade" com a qual tratou a interpretação econômica da história, sobretudo o pensamento de Karl Marx, sobre o qual percebeu a presença de "forças emocionais" que teriam prejudicado a objetividade da análise: "ele não pode ser criticado sem que o crítico receba o tratamento que se dava aos hereges. Tem que ser visto como perfeito, de valor permanente" (IGLÉSIAS 1959, p. 63). Além de lamentar o fato do pensamento de Marx ter sido bandeira de reivindicações sociais, Iglésias ainda criticou o que classificou como uma modificação do ângulo de análise e do interesse do autor: o uso de suas ideias na luta anti-imperialista e nacionalista, questões que movimentavam os intelectuais da época e que se fazia presente, sobretudo, no ISEB (Instituto Superior de Estudos Brasileiros), o lugar de onde Sodré falava. Dentre as fontes citadas e que poderiam ter motivado as críticas de Sodré estava a obra La vocation actuelle de la sociologie, de Georges Gurvitch. O autor defendia o ideal do cientista neutro e desinteressado e afirmava que o pensamento de Marx tinha sido objeto de deformação ideológica, sobretudo na configuração da equivocada teoria do fator econômico predominante.

Em Introdução à historiografia econômica, Francisco Iglésias pretendeu "evidenciar a modernidade da historiografia econômica" e relacionar seu

Francisco Iglésias. Ano letivo 1956; Diário de Classe e Relação Geral do Ano. Aula de História da Economia do $3^{\circ}$ ano, turma única. Professor Francisco Iglésias. Ano letivo 1958. Arquivo da Memória Institucional da FACE/UFMG. 
surgimento a alteração da ordem social europeia. O aparecimento e o desenvolvimento da historiografia econômica foram ainda compreendidos no contexto mais amplo da ciência social e dos estudos históricos:

Se a sociologia afirma que todos os fenômenos sociais são fenômenos globais, com o desenvolvimento das pesquisas históricas tornou-se evidente a necessidade de especialização. Era impossível a alguém dominar toda a matéria que se compreendia sob os títulos ambiciosos de História Universal, História Geral ou História da Civilização. Impunha-se ao estudioso a especialização em determinado povo, época ou tipo de atividade ou preocupação. Tomando-se a matéria no seu todo, deviase fazer algum corte em sua realidade, para mais atenda e fecunda consideração (IGLÉSIAS 1959, p. 14).

Não obstante o reconhecimento da necessidade da especialização, Iglésias não ignorou que "não existe, em toda a sua pureza, o fato econômico, o fato político, o fato artístico ou religioso", e que a decomposição do fato social em diferentes aspectos seria necessária para observá-lo melhor, conforme ensinava Marc Bloch, autor insistentemente citado. Ao estudioso seria impossível "manterse com rigor na sua esfera, sem episódicas interferências em campo alheio" (IGLÉSIAS 1959, p. 16-17). Daí que, objetivando pesquisar a política econômica da província mineira para elaboração de sua tese, ele não se viu obrigado a restringir-se à vida econômica. Seu propósito foi "evidenciar a realidade econômica, a situação material sob a influência do governo" (IGLÉSIAS 1959, p. 12), sendo assim, precisava dar atenção ao elemento político e administrativo.

Além de tentar preencher uma lacuna na historiografia com a produção de um conhecimento original, é possível que Francisco Iglésias tenha sido influenciado na escolha de seu tema por uma indicação relativa aos documentos utilizados. O cientista social Manuel Diegues Júnior, ao comentar a publicação, declarou que ele próprio já havia chamado a atenção em sua coluna no jornal Diário de Notícias para as falas e mensagens dos Presidentes de Província como documentos valiosos para a reconstituição da vida provincial e da própria história do Império, fonte notadamente privilegiada pelo autor (DIEGUES JÚNIOR 1959). $\mathrm{O}$ artigo teria sido publicado seis anos antes, exatamente quando Iglésias dava início à sua investigação. Para Diegues Júnior, a maneira como os problemas da administração eram encarados, encaminhados ou resolvidos na vida provincial, revelava grande parte do segredo da história do Império brasileiro. Na sua avaliação, estudos assim deveriam ser seguidos por outros historiadores em relação às demais Províncias, pois "trata-se de contribuição fundamental para que se escreva, no devido tempo, a história do Império, ainda tão vazia" (DIEGUES JÚNIOR 1959).

\section{Os exercícios de crítica e de autocrítica}

Quando terminou a sua tese, Francisco Iglésias escreveu uma longa carta à professora Alice Canabrava expondo os problemas que já percebia em seu trabalho e manifestando desânimo em relação a ele. A partir da resposta da correspondente, pudemos inferir que Iglésias reclamou das "imprecisões", do 
caráter incompleto e do "tom cronista" de seu próprio trabalho. Sua autocrítica denunciava sua insegurança em relação ao cumprimento dos pressupostos que ele mesmo havia postulado. Canabrava, que fez parte da comissão julgadora do concurso, tratou de consolá-lo:

Acredito sinceramente que seu trabalho vale - com todas as imperfeições que você mesmo aponta. Sua tese deve ter muitos aspectos positivos e entre os muitos um é evidente: a sua coragem em se propor em realizar a pesquisa, em meio adverso. Outro: a base sólida, das fontes primárias. São aspectos positivos e que ficam, Iglésias, a despeito de tudo o que puderem criticar, atacar, ou destruir do seu trabalho. ${ }^{6}$

Após a publicação da tese, entretanto, as resenhas e os vários comentários que revelam a repercussão imediata do seu trabalho se ativeram em pormenores. ${ }^{7}$ As notas de Daniel de Carvalho sobre o livro-foram feitas para destacar o que seriam, para o crítico, três problemas da tese: a omissão de duas fábricas de tecido de Itabira na relação das principais da Província; a consideração da escravidão como razão preponderante para afastar as correntes migratórias para o Brasil; e a parte referente aos índios, que pareceu a Carvalho "muito sumária e omissa" (CARVALHO 1959, p. 4). As críticas foram posteriormente incluídas no livro Ensaios de crítica e de história (1964), do mesmo autor, acrescentadas de outras observações sobre a maneira como Francisco Iglésias tratou de temas como a agricultura, a siderurgia, a navegação fluvial, o ensino técnico e as estradas de Minas Gerais em sua tese.

Contra a afirmação de que "ainda que não animada pelo Governo Português que Ihe criou até alguns embaraços - pois só pensava em outra riqueza desenvolveu-se a lavoura de subsistência" (IGLÉSIAS 1958, p. 61), Carvalho argumentou que a metrópole estimulou a agricultura e a criação de animais para o suprimento das minas de ouro. Esse incentivo se dava, sobretudo, através da oferta de sesmarias. Se houve proibição de engenhos em certos períodos, aconteceu em decorrência da política econômica mercantilista e da preocupação de que a abundância de aguardente pudesse comprometer a ordem na colônia, segundo Carvalho. Em relação à indústria, o crítico também questionou as afirmações de que a atividade industrial mineira foi feita "sem assistência técnica ou auxílio dos poderes públicos" e de que a Coroa portuguesa procurava evitar o trabalho industrial (IGLÉSIAS 1959, p. 90-91). Ele lembrou que a siderurgia sempre mereceu apoio da monarquia lusitana e ofereceu dados para comprovar os numerosos atos da metrópole em favor da indústria do ferro. É curioso observar que as críticas de Carvalho às afirmações de Iglésias nestes aspectos se restringem à realidade da Capitania e não da Província, que foi o tema da monografia.

${ }^{6}$ Carta de Alice Canabrava a Francisco Iglésias em 10 de maio de 1954. Instituto Moreira Sales. Coleção Francisco Iglésias.

7 Ver, por exemplo, José (1959), Costa Filho (1959, p. 3), Olinto (1959, p. 12), Degues Júnior (1959), Viana (1959), Campomizzi Filho (1959, p. 4), SODRÉ (1959, p. 6-12), Carvalho (1959a; 1959 b, p. 4, 11), entre outros. 
As minúcias observadas por Carvalho levaram a "correções" de propósito duvidoso. Ao comentar a afirmação de Francisco Iglésias de que as comunicações de Minas Gerais com a Bahia, São Paulo e Rio de Janeiro "foram feitas, um pouco ao acaso, ora aproveitando os caminhos de índios, ora os primeiros trilhos das passadas do sertanista" (IGLÉSIAS 1958, p. 153), ele afirmou que "não se pode emparelhar situações tão díspares", contra-argumentando que a ligação de Minas com Bahia foi sempre pelo Rio São Francisco (CARVALHO 1964 , p. 82). Mas o fato de haver uma linha fluvial de navegação, conforme observou Carvalho, não anulava a constatação de que as picadas orientaram a comunicação terrestre entre aqueles núcleos, conforme enfatizou Iglésias. Outro trecho confrontado por Carvalho foi aquele em que o autor teria afirmado que, "quanto ao índio, por suas condições e traços culturais, não tem grande contribuição nesse particular [a lavoura]" (CARVALHO 1964, p. 70). Entretanto, não encontramos a passagem referida por Carvalho na publicação de 1958 , que foi a sua referência para empreender o comentário à obra.

Entre outros pormenores da tese, "desmentidos por fatos incontestáveis" nas palavras de Carvalho (CARVALHO 1964, p. 79), ele também chamou a atenção para certa ausência de crítica na forma como Francisco Iglésias lidou com a documentação. Em relação ao uso do relatório de 1843, do Presidente Soares Andreia, por exemplo, Carvalho observou que seria preciso considerar o tom pitoresco característico de sua linguagem para perceber os exageros de suas afirmativas (CARVALHO 1964, p. 79). Essa ausência de crítica documental poderia ser encarada como um dos reparos mais graves feito à tese, visto que sua pretensão era justamente utilizar uma documentação copiosa e tratá-la com discernimento e método.

Para Nelson Werneck Sodré, a tese de Francisco Iglésias constituía "contribuição informativa apreciável, útil a todos os que se interessam pelo estudo da nossa história econômica" (SODRÉ 1959, p. 7). Oiliam José destacou que o autor não se deixou levar pelos ciclos então dominantes da economia mineira, abrangendo também as demais atividades produtoras de riqueza na província (JOSÉ 1959, p. 261). Campomizzi Filho acrescentou que o grande mérito do trabalho foi não ter se concentrado no estudo da economia interna de Minas Gerais, mas apresentar o debate do problema administrativo das províncias. 0 que o resenhista mais valorizou foi o que a tese trouxe de informação da história política. Ele elogiou a estruturação dos capítulos e a linguagem agradável, ao mesmo tempo em que afirmou que a tese de Francisco Iglésias "prestou às nossas letras históricas um admirável serviço" (CAMPOMIZZI FILHO 1959, p. 4).

Mas o lugar de onde estes críticos falavam não era aquele no qual Francisco Iglésias havia buscado posicionar o seu trabalho. Embora Campomizzi Filho tenha afirmado que o empenho para que a tese aparecesse em livro foi decorrente da repercussão que ela conseguiu nos meios acadêmicos brasileiros, o fato é que a historiografia produzida pela universidade privilegiaria, pelo menos até meados dos anos 1970, os modelos explicativos da economia colonial como reflexo da dinâmica internacional. As observações sobre a carência de estudos da província mineira feitas na década de 1950 rsitária retomou o assunto no contexto da 
crítica da tese da decadência de Minas Gerais no século XIX. ${ }^{8}$ Os estudos que tiveram como objetivo compreender a colônia a partir de suas condições internas renovaram o interesse pelo conhecimento das realidades regionais e, consequentemente, procuraram estabelecer um diálogo com os exíguos trabalhos sobre o tema realizados no passado. A originalidade da tese de Francisco Iglésias - objetivo perseguido em função de sua concepção de trabalho universitário tornou inevitável o retorno da historiografia contemporânea à sua obra. ${ }^{9}$

\section{Considerações finais}

As primeiras produções do historiador Francisco Iglésias a partir de sua efetivação como docente na UFMG mostram que sua inserção na prática formal do discurso acadêmico refletiu na maneira como ele concebeu a pesquisa cientifica e na forma como ele diferenciou a sua historiografia de outras narrativas históricas alheias ao ambiente universitário. Embora a alteração do lugar privilegiado da produção histórica que ocorreu com a ampliação do ensino superior brasileiro e a institucionalização dos cursos de história não tenha correspondido imediatamente a uma substancial modificação das questões e das metodologias na abordagem do passado, houve uma reconfiguração da função social do historiador e da legitimação de seu trabalho diante daqueles que não possuíam uma formação especializada.

O processo de normatização disciplinar do conhecimento histórico deixou suas marcas nos empreendimentos de escrita específicos através da estruturação do texto, das justificativas teórico-metodológicas, das citações e dos diálogos com outros historiadores. Procuramos estes indícios nos textos de Francisco Iglésias para averiguar tanto as mudanças suscitadas pela dinâmica universitária da produção do conhecimento, como as permanências de ideias e práticas nem sempre coerentes com o discurso que buscava superá-las.

Vimos que a vinculação institucional do texto de Francisco Iglésias foi indiciada pela justificação da escolha temática de sua tese de livre docência, pelo exercício da autolocalização de sua contribuição intelectual, pelo diálogo com a bibliografia pertinente e com outros pesquisadores da comunidade científica que garantiam a linguagem referencial da sua historiografia. Seu discurso historiográfico conduziu o leitor ao próprio lugar de onde falava: ele mostrou que sua escrita era controlada por práticas consideradas inerentes à instituição ao qual estava vinculado - a universidade -, o que supostamente a tornava mais legítima.

\footnotetext{
${ }^{8}$ A tese da decadência de Minas Gerais no século XIX foi defendida por Celso Furtado em 1959. Ela pode ser considerada como herdeira dos estudos de Caio Prado Júnior sobre a economia colonial, interpretada como dependente do mercando internacional e carente de mercado interno. De fato, para ser plenamente compreendida, essa tese deve ser analisada no contexto dos modelos explicativos da economia colonial, pois a hipótese de uma "involução" econômica em Minas Gerais é tributária da perspectiva de que a colônia seria incapaz de promover acúmulo de capital de forma endógena. A crítica da tese da decadência de Minas Gerais apareceu quando se questionou a incapacidade da colônia de reter parte do excedente acumulado.

9 Os trabalhos recentes que recuperaram o diálogo com a tese de Francisco Iglésias foram realizados, sobretudo, por pesquisadores da história econômica, dentre os quais destacamos: Godoy e Barbosa (2008) e Freitas (2009).
} 


\section{Referências bibliográficas}

BOURDIEU, Pierre. Homo academicus. Florianópolis: Ed. UFSC, 2011.

CAMPOMIZZI FILHO. Política econômica do governo provincial mineiro. Folha de Minas, p. 4, 23 abr. 1959.

CARVALHO, Daniel de. Notas ao livro do Prof. Francisco Iglésias: a tecelagem, a imigração, os silvícolas. O Diário, 15 out. 1959.

A economia da província de Minas Gerais. In:

Ensaios de crítica e de história. Rio de Janeiro: edição do autor, 1964.

CERTEAU, Michel de. A escrita da história. 2. ed. Rio de Janeiro: Forense, 2008.

CÔRTES, Norma. Debates historiográficos brasileiros: a querela contra o historicismo. In: MOLLO, Helena Miranda et al. (Org.). A dinâmica do historicismo: revisitando a historiografia moderna. Belo Horizonte: Argvmentvm, 2008, p. 229-243.

DELACROIX, Christian; DOSSE, François; GARCIA, Patrick. Correntes históricas na França: séculos XIX e XX. Rio de Janeiro: FGV, 2012.

DIEGUES JÚNIOR, Manuel. A vida provincial. Diário de Notícias, 5 abr. 1959.

FERREIRA, Marieta de Moraes. A História como ofício: a constituição de um campo disciplinar. Rio de Janeiro: FGV, 2013.

FOUCAULT, Michel. A ordem do discurso. São Paulo: Loyola, 2003.

GRAFTON, Anthony. As origens trágicas da erudição: pequeno tratado sobre a nota de rodapé. Campinas: Papirus, 1998.

HECKSHER, Eli F. La época mercantilista. México: Fondo de Cultura Económica, 1943.

IGLÉSIAS, Francisco. Generalidades sobre a história de Minas Gerais. Estado de Minas, p. 1, 19 jun. 1949.

. Minas e um problema da historiografia brasileira. Tribuna de Minas, 1 mai. 1952.

- Aspectos do desenvolvimento da história econômica. Revista da Faculdade de Ciências Econômicas, n. 6, p. 15-39, 1954.

Política Econômica do Governo Provincial Mineiro (1835-1889). Rio de Janeiro: INL, 1958.

JOSÉ, Oiliam. Historiografia Mineira. Belo Horizonte: Itatiaia, 1959.

SODRÉ, Nelson Werneck. Uma tese. O Semanário, ano IV, n. 162, 6 a 12 jun. 1959.

Monografias. O Semanário, ano IV, n. 171, 8 a 14 ago. 1959. 


\title{
As regras por detrás dojogo: a operação historiográfica de Michel de Certeau na obra de Wlamyra $R$. Albuquerque
}

\author{
The rules behind the game: Michel de Certeau's historiographical \\ operation in Wlamyra R. Albuquerque's work
}

\author{
Rômulo Gonçalves Bittencourt \\ romulo.g.bittencourt@gmail.com \\ Especialista em Direito Constitucional \\ Universidade Federal da Bahia - Campus de São Lázaro \\ Aristides Novis, 197 - Federação (Estrada de São Lázaro) \\ 40210-730 - Salvador - Bahia \\ Brasil
}

\section{Resumo}

O presente artigo se propõe a aplicar a matriz de Michel de Certeau a uma obra historiográfica, $O$ jogo da dissimulação: abolição e cidadania negra no Brasil, de Wlamyra Ribeiro de Albuquerque, de modo a mapear os três elementos componentes da operação historiográfica: lugar social, as práticas e a escrita. Através da análise dos elementos sobre os quais o discurso não fala será demonstrado o nível de participação do historiador no processo de efetivação da pesquisa acadêmica. Desse procedimento resulta a possibilidade de controlar em toda extensão o discurso histórico produzido, ratificando o caráter cientifico do conhecimento histórico, além de promover reflexões atuais sobre questões históricas.

\section{Palavras-chave}

Narrativa historiográfica; Michel de Certeau; Discurso.

\begin{abstract}
This paper proposes to apply Michel de Certeau's matrix to a historiographic work, O jogo da dissimulação: abolição e cidadania negra no Brasil, written by Wlamyra Ribeiro Albuquerque, in such a way as to map the three components of historiographical operation: social place, practices, and writing. Through the analysis of elements which the discourse does not speak of it will be shown the level of participation of the historian in the process of the research realization. From this procedure results the possibility of monitoring in the fullest extent the historical speech produced, ratifying the scientific character of historical knowledge, in addition to promoting current reflection on historical issues.
\end{abstract}

Keywords

Historiographical narrative; Michel de Certeau; Discourse.

Recebido em: 21/10/2016

Aprovado em: 9/3/2016 


\section{O problema da narrativa histórica}

A celeuma em torno da natureza epistemológica do conhecimento histórico, apesar de não tão recente, ${ }^{1}$ ainda se mantém aquecida no âmbito histográfico. Nesse contexto, as problemáticas derivadas das peculiaridades da narrativa histórica podem ultrapassar a dicotomia reinante no campo teórico entre tradução da realidade pretérita e mero elemento textual, sendo a matriz de Michel de Certeau contributiva no sentido de reconhecer a indissociabilidade do aspecto literário ao discurso histórico, porém mitigado por elementos controláveis (OHARA 2013).

A publicação da obra A escrita da História (2015) demonstrou o anseio de Michel de Certeau em estabelecer postulados que apresentassem ferramentas capazes de dissecar o discurso histórico e, a um só tempo, ratificar o caráter científico do fazer historiográfico. Tal caráter, aqui, deve ser compreendido como "um conjunto de regras que permitam 'controlar' operações destinadas à produção de objetos determinados" (CERTEAU 2015 p. 47, nota 5), ou, como disse Chartier (2015, p. 16), ou seja, a História produz discurso científico por se caracterizar como um regime de saber compartilhado.

Mesmo após 30 anos de sua morte, as contribuições de Certeau se mantém hígidas, justamente por não desconsiderarem o caráter singular que o ato de escrever história pressupõe, ou seja, a narrativa histórica seria um processo construtivo e transformador. Não obstante o caráter performativo da produção histórica disfarçado de releitura do passado, ${ }^{2}$ é possível estabelecer balizamentos utilizando os elementos componentes da operação historiográfica (CERTEAU 2015, p. 45-111). Compreender o complexo ato de fazer história como uma operação significa, para Certeau, estabelecer critérios teóricos que delimitem a produção historiográfica. Limites estes, contudo, que não desconsideram o caráter inventivo, transformador e literário do historiador. Sua maior contribuição é não colocar tais questões para debaixo do tapete. Ao revés: escancara as influências externas, denuncia as regras que permeiam o ato de escrita e, sobretudo, revela que a narração, mesmo sendo performática, pode ser controlada.

Orellana (2012, p. 22) defende que os elementos fulcrais da matriz certeauniana seriam a relação subordinativa ao vínculo institucional, o caráter construtivo das fontes e a aproximação de escrita histórica e ficção. Em acréscimo, percebo que todos estes enunciados estão voltados, em especial, ao discurso do historiador, expresso no texto escrito. Seguindo a lógica de Voigt (2014), a discussão central de Certeau está voltada para a escrita, aqui encarada pelo seu viés narrativo, embora esta análise pressuponha o estudo prévio do lugar

\footnotetext{
${ }_{1}^{1}$ Uma das possíveis reflexões sobre o status cientifico da História se concentra no debate sobre o caráter da narrativa histórica. De Leopold Van Ranke a François Dosse, passando por Robin George Collingwood, Paul Veyne e Roger Chartier, até o debate entre Carlo Ginzburg e Hayden White, a teoria da história ainda se encontra envolvida pela necessidade de compreensão da natureza mesma do conhecimento histórico.

2 Nesse ponto me afasto da concepção de Durval Albuquerque Jr. (2009a), que identifica a operação historiográfica de Michel de Certeau como um caráter maquínico, haja vista o referido historiador não rejeitar o aspecto criativo no processo de produção textual - apenas defende, em síntese, que o discurso histórico, apesar de performático, não é aleatório, já que se articula com o lugar social do historiador e as técnicas metódicas (VOIGT 2014).
} 
social e da forma procedimental com que o historiador lida com as fontes e com a própria História, isto é, as práticas.

Mesmo partindo dessas premissas, nada faz sentido caso não seja visualizado o historiador como aspecto central de todo este processo. Afinal, é o seu agir que otimizará a articulação dos três componentes sobre os quais o discurso não fala. Encarado o problema dessa forma, percebo que o olhar sobre os fundamentos do conhecimento histórico não se dissocia da prática histórica. A relação simbiótica entre teoria e base empírica contempla, assim, uma análise conjunta.

\section{Os postulados de uma ciência histórica: a matriz certeautiana}

As preocupações lançadas por Michel de Certeau no capítulo $A$ operação historiográfica se lastreiam na tentativa de compreensão da natureza central do complexo processo de elaboração de um texto com conteúdo voltado para o passado. ${ }^{3}$ Em outras palavras, pretende o referido autor fazer emergir a engrenagem que compõe o ofício do historiador. O produto histórico seria-a reunião de um lugar social, de procedimentos práticos analíticos e de uma construção textual, postulados sobre os quais, como dito, o discurso não fala (CERTEAU 2015, p. 46). Porém, mesmo silencioso, o discurso produzido não deixa escapar os limites, funções e escopo do ato de escrever história. Haveria, assim, um tripé silencioso que sustentaria toda operação histórica.

Nesse cenário, o local institucional em que está imerso o historiador oferece instrumentos e condicionantes para o estudo sobre o passado. Este aspecto, 80 para Certeau, apesar de não dito, integra as decisões do historiador, seja na elaboração da pesquisa, seja na própria escrita. Já os procedimentos técnicos que vão nortear a pesquisa acadêmica ultrapassam a simples escolha metodológica. Certeau encara essa fase como uma criação instrumental do historiador, que propiciará, por meio do arcabouço material, subsídios para a narrativa, além de contemplar a própria identidade do pesquisador às funcionalidades da História. Por fim, o texto será fruto da capacidade do historiador em transitar pelas especificidades que a narrativa histórica pressupõe, conferindo-Ihe credibilidade e inteligibilidade, tornando-se, assim, discurso.

Apesar desses componentes se encontrarem diluídos nos textos historiográficos, apresento como proposta deste artigo tornar visível tal universo submerso. Proponho, assim, mapear os pressupostos teóricos ventilados por Michel de Certeau em uma obra historiográfica específica. Por meio desse procedimento, será possível identificar o grau e a intensidade do historiador na construção do conhecimento histórico, que permeia todo o caminho da pesquisa e, até muitas vezes, antes dela. Compreendendo essa unidade divisível, pretendo utilizar o livro $O$ jogo da dissimulação: abolição e cidadania negra no Brasil, de Wlamyra Ribeiro de Albuquerque (2009), para demonstrar a viabilidade e pertinência das propostas de Certeau em sua operação historiográfica, cujo conteúdo remete ao esforço de legitimação do próprio produto histórico. ${ }^{4}$

\footnotetext{
${ }^{3}$ A partir deste ponto, ao referir-me a Michel de Certeau, estarei mencionando Certeau (2015).

${ }^{4} \mathrm{Em}$ momento algum no texto afirmo ter Albuquerque utilizado a operação historiográfica de Certeau como referencial teórico; reconheço, como será melhor apontado adiante, que a análise da autora está sustentada
} 
A obra a ser analisada remete à tese de doutorado da historiadora Wlamyra Ribeiro de Albuquerque, que se propõe a analisar a conformação dos novos contornos sociais no período final do século XIX no Brasil pelo viés de que a racialização das relações foi forjada por diversos setores, num complexo jogo de disputas de espaço, sobretudo após a abolição da escravatura. A escolha se deve a dois fatores: (i) trata-se de uma obra que amplia as discussões sobre a condição dos ex-escravos no período pós-emancipacionista, relativizando o limiar entre escravidão e trabalhadores livres sob o viés cultural (racialização das relações sociais) e (ii) por inovar, no âmbito historiográfico, o aspecto da constituição racial como modulador da sociedade brasileira no final do século XIX, de modo a historicizá-lo. ${ }^{5}$

\section{O pertencimento da autora}

Elemento precedente da pesquisa, o ambiente que norteia a historiadora serve como vestígio das decisões que marcam a sua vida acadêmica. Entretanto, para além de um possível determinismo acadêmico, não se pode desconsiderar o que atravessa e o que é atravessado no ato da pesquisa e na escrita.

A trajetória pessoal de Wlamyra Albuquerque deixa transparecer o fato de haver uma relação necessária entre escolhas, identidades e vínculo institucional. ${ }^{6}$ Afinal, ainda que inicialmente não tenha vislumbrado as possibilidades que o conhecimento histórico iria lhe proporcionar, a estudante recém-formada em um contexto tão opressor e ao mesmo tempo tão fascinante como o da cidade de Salvador percebeu desde logo que suas inquietações mereciam uma reflexão aprofundada: "ter saído da periferia e circulado em espaços absolutamente improváveis, que jamais pensaria ter um dia transitado ou ocupado, isso definiu o meu lugar como pesquisadora, os meus interesses de estudo" (ALBUQUERQUE 2016).

Esse caminhar não-linear, portanto, é permeado de subjetividade e de percalços. O debruçar sobre estudos da historiografia escravista foi, assim, uma escolha transindividual, por aliar um desejo e uma demanda social. Dentro dessa ausência de um sentido lógico, mesmo após a conclusão de sua dissertação, defendida em 1997 no Programa de Pós-Graduação em História da Universidade Federal da Bahia, intitulada O civismo festivo dos baianos: comemorações da independência na Bahia (1889-1923), Albuquerque ainda não havia sintetizado e reverberado suas inquietações. Nesse trabalho, especificamente, propôs uma reconstrução da pluralidade de significados políticos que os festejos da independência da Bahia, comemorada no 2 de julho, assumem no final do século XIX (KRAAY 2001/2002, p. 255).

na História Social da Cultura, "a qual tem em Thompson e Geertz as principais referências", como indicada por um dos pareceristas anônimos deste artigo.

${ }^{5}$ Walmyra Albuquerque, em réplica à resenha produzida sobre sua obra, elencou três outros trabalhos que circunscrevem o tema racial no período emancipacionista brasileiro (cf. ALBUQUERQUE 2011).

${ }^{6}$ Parte das informações que compõem a seção 2 e parcialmente a seção 4 deste artigo foi obtida a partir de entrevista concedida por Wlamyra Albuquerque ao autor em 7 de outubro de 2016, nas dependências da Biblioteca Reitor Macedo Costa, no Campus Ondina da Universidade Federal da Bahia. 
Talvez o próprio lugar de produção acadêmica, o Programa de Pós-Graduação em História da Universidade Federal da Bahia, não estivesse permitindo maiores desdobramentos em sua pesquisa. O não dito que denuncia Certeau é latente: procurar novos desafios poderiam lhe proporcionar um novo olhar, a mensurar anseios e propósitos:

[...] [n]ão é só talento que faz acontecer, o que faz são as oportunidades e os deslocamentos. A gente cresce quando se desloca. O modo como produz ciência está diretamente relacionado com as escolhas e a forma como lidamos com a vida. Quanto mais você se coloca no que Ihe é confortável menos chance se terá de produzir algo original. [...] O deslocamento, o estranhamento de situações e locais diferentes, o desafio da alteridade, de se colocar no lugar do outro e da empatia (e se dando conta das diferenças), é estruturante para uma historiadora. A gente sofre, mas passa. O importante é encarar isso como desafio (ALBUQUERQUE 2016).

Ainda dentro dos estudos sobre a escravidão, Wlamyra Albuquerque ingressou na linha de pesquisa de História Social da Cultura da Universidade Estadual de Campinas. Preciso, nesse ponto, registrar que os dois Programas de Pós-Graduação possuem uma conexão entre si. Segundo Albuquerque (2016), a experiência vivida entre as duas instituições mostrou a forte identidade de temas, objetos de estudo e formas narrativas entre elas. Em sua perspectiva, essa aproximação se deve, em especial, pela intermediação do historiador João José Reis, ${ }^{7}$ que teria fomentado esse diálogo acadêmico.

Retomando ao momento de acesso aos estudos prévios à realização de sua tese, Albuquerque, ao se deparar num ambiente de hegemonia branca, se insere na discussão sobre a implantação de cotas em universidades públicas, em pauta nos idos de 2002. Numa sociedade marcada pela desigualdade, se propõe a historicizar o conceito de raça, de modo a buscar compreender o processo em que se deu, no período do Brasil emancipacionista, a conformação e os arranjos sociais pautados em critérios raciais (ALBUQUERQUE 2016). Considero que o cenário vigente foi provocativo e instigou a autora a qualificar o tema racial para o âmbito de sua pesquisa. Os problemas hodiernos resultantes da constituição da raça como parâmetro social parecem ter estimulado Albuquerque a estudar e compreender a própria historicidade deste conceito tão caro à sociedade brasileira.

Essa inquietação pode ser traduzida como os interesses, aspecto estabelecido por Jörn Rüsen (2001, p. 164) como inicial na produção historiográfica, isto é, "carências de orientação humana na vida prática, decorrentes das experiências da contingência da evolução temporal do mundo humano". Em suma, os

\footnotetext{
7 Joao José Reis é historiador que dispensa apresentações. Ainda assim, reproduzo as palavras Durval Muniz Albuquerque Jr. (2009b, p. 211) que sintetizou o lugar por ele ocupado entre historiadores de prestigio: "João José Reis é merecidamente um figurão da historiografia brasileira. Seus livros, desde o pioneiro Rebelião escrava no Brasil, modificaram o estado da arte dos estudos sobre escravidão, sobre rebelião escrava e movimentos sociais, não só no país, mas internacionalmente".
} 
interesses são provocados e estimulados por carências de orientação de temas presentes. ${ }^{8}$ Ora, o passado necessita ser revisitado diante das demandas sociais da atualidade, influenciando, pois, novas abordagens de estudos. Por essa razão, inclusive, "uma situação social muda ao mesmo tempo o modo de trabalhar e o tipo de discurso" (CERTEAU 2015, p. 59).

Preciso, porém, pontuar que o objeto de pesquisa de Albuquerque sobre os períodos pré e pós-abolicionistas somente se fez possível diante do amadurecimento das discussões sobre a própria historiografia da escravidão, ${ }^{9}$ a qual se renovou no final da década de 1980 e notadamente se alargou pela ampliação dos Programas de Pós-Graduação em História no país durante os anos 1990 e 2000.10 Assim, vejo o que permite e o que proíbe propostos por Certeau como elementos mitigadores da liberdade individual da historiadora: a pesquisa (e, por extensão, a escrita) não é um ato livre, porque o lugar social abre possibilidades de estudo e fecha outras. O edifício historiográfico sobre a escravidão diversificou fontes, métodos e avanços sobre a complexidade envolvendo a sociedade brasileira, ultrapassando a visão binária e maniqueísta de escravos e senhores. ${ }^{11}$ Schwartz (2001, p. 24-29) esclarece que o centenário da abolição, em 1988, intensificou os estudos anteriores sobre a escravidão e deu novo fôlego a dois eixos centrais ao tema: a escola de São Paulo e Frank Tannenbaum. Logo, as novas produções acadêmicas, nas quais se insere a obra de Albuquerque, se encontram vinculadas a este caminho historiográfico.

A instituição histórica (CERTEAU 2015, p. 51-57), como universo doutrinário (ora exemplificada pelas Universidades e Instituições de pesquisa) se retroalimenta das produções historiográficas. Entretanto, chamo atenção ao fato de que as produções acadêmicas resultam de tensões criadas pela própria academia. Ora, o discurso histórico é destinado sobretudo a este progresso historiográfico, o qual não se faz senão com embates. A instituição histórica (in)valida a produção textual realizada pelos historiadores: não é à toa que a obra de Albuquerque aqui analisada tenha sido objeto de diversas resenhas. ${ }^{12}$ A recepção pelos "seus pares" a que menciona Certeau (2015, p. 57) é um rito indispensável para incorporação de um estudo ao universo historiográfico.

A propósito, Lima (2009), em resenha ao livro de Albuquerque, menciona que a obra não teria alcançado a contento seu principal propósito de revelar as estratégias esquemáticas de utilização da raça como critério de hierarquização social. Em suas palavras, "Wlamyra tende a ler os conflitos sociais que encontra

\footnotetext{
8 Para melhor visualização do elemento interesses proposto por Rüsen (2001) em uma obra historiográfica, ver Pereira (2007).

9 Para melhor visualização deste caminhar sobre os estudos de temas envolvendo escravidão vide o balanço historiográfico em Schwartz (2001).

10 Embora Carlo Fico e Ronald Polito (1992, p. 33) afirmem que a criação dos programas de PósGraduação tenha se iniciado no Brasil na década de 70, foi no período de 80-89 que tais institutos se consolidaram. Esse processo de expansão novamente se intensificou, passando de 16 Universidades a oferecer cursos de especialização para os atuais 110, conforme estatística da CAPES. Disponível em: https://sucupira.capes.gov.br/sucupira/public/consultas/coleta/programa/quantitativos/quantitativoIes. jsf ?areaAvaliacao $=40 \&$ areaConhecimento $=70500002$.

${ }_{11}$ Como indicado por um dos pareceristas anônimos deste trabalho, essa renovação se deve em especial à utilização do referencial teórico-metodológico da escola marxista britânica, sobretudo de Thompson, adotando uma história "vista de baixo".

12 Nesse sentido, ver Lima (2009), Brito (2011), Cowling (2011), Domingues (2011) e Gomes (2011).
} 
majoritariamente como conflitos 'raciais', promovendo a simplificação do quadro de antagonismos, negociações, indignações, identificações" (LIMA 2009, p. 252).

Em réplica, Albuquerque (2011) rebate o suposto insucesso da hipótese, retomando questões nela fixadas para demonstrar que o jogo social que pautou a sociedade brasileira pós-abolicionista não se resumiu a uma relação cartesiana binária. Segundo ela, "[n]o período que investiguei, a população negra também forjou identidades a partir de um discurso racial. É o que evidencio no último capítulo do livro sobre clubes carnavalescos repletos de gente de cor, brasileira, que, publicamente, se dizia africana" (ALBUQUERQUE 2011, p. 292).

A autora ainda pontua a necessidade de reflexão do tema proposto, numa clara defesa argumentativa sobre as criticas direcionadas por Lima (2009):

[...] [p]or fim, o resenhista supõe ter descoberto a intenção por trás do argumento do livro: sensibilizar politicamente os leitores 'em relação à denúncia ao racismo'. Ora, denunciar o racismo num país onde ainda se teme enfrentá-lo não é tarefa menor, mas em $O$ jogo da dissimulação pretendo e realizo um tanto mais. Por isso, com a simplicidade que me cabe, convido os leitores a lê-lo e tirar as suas próprias conclusões (ALBUQUERQUE 2011, p. 296).

Acaso as leis do meio (CERTEAU 2015, p. 57) fossem desimportantes, tal debate não ocorreria. Mas, pelo contrário, ele é mais um elemento constituidor da própria produção historiográfica. Seguindo as linhas de intelecção de Certeau, ouso afirmar que a pesquisa tem como destinatários diretos a sociedade e o próprio cenário acadêmico, afinal as produções históricas ultrapassam o interesse acadêmico, possuindo também a repercussão das obras junto ao público em geral (FICO; POLITO 1992, p. 141).

Dessa forma, o mercado editorial apesar de estimular esse nicho, também estabelece critérios de modo a tornar obras produzidas com regras da academia acessíveis a este público. Nesse sentido, a obra de Albuquerque, por tratar de uma experiência ainda persistente em nossa sociedade e utilizar variadas fontes, inclusive literárias e poéticas, mostra as possibilidades de tornar mais atraente tal tema ao universo não acadêmico, sem perda das características essenciais de produção do conhecimento histórico.

A produção historiográfica é, portanto, muito mais um conjunto de interferências do meio (seja ele individual, social ou institucional) do que um resultado abstrato extraído do passado. Sendo assim, o jogo da dissimulação a que alude Albuquerque serve também para compreender as produções acadêmicas, resultado do cruzamento de reservas de domínio: institucional, individual e social, num verdadeiro palco de conflitos e tensões não declarados. As provocações de Michel de Certeau ainda possuem um caráter denunciante.

\section{Para além do tecnicismo}

A realização da pesquisa acadêmica ultrapassa a instrumentalização metódica e requer, conforme defende Certeau, uma atuação do agente-historiador, que não só medeia o processo de seleção documental como também age na 
elaboração de um contexto histórico a subsidiar a futura narrativa. Entretanto, o sujeito articulador desse processo não é essencialmente livre: existem balizas. Nesse sentido, "o lugar que se dá [o historiador] à técnica coloca a história do lado da literatura ou da ciência" (CERTEAU 2015, p. 65).

O cerne da discussão lançada por Albuquerque na obra em análise é desvelar o processo de racialização das relações sociais durante o período entre a emancipação do Brasil e o fim da escravidão, isto é, demonstrar os caminhos de elaboração de discursos raciais como critério de hierarquização e moldura da sociedade baiana no final do século XIX. O jogo da dissimulação: abolição e cidadania negra no Brasil trata de três episódios que constituem o núcleo duro da narrativa, os quais não se encontram intrinsecamente interligados: o incidente diplomático envolvendo Inglaterra e Brasil acerca do desembarque de dezesseis africanos em 1877 no porto de Salvador; o caso intitulado o massacre do Taboão e as representações do desfile do clube Embaixada Africana e dos Pândegos d'África no carnaval de 1897 na cidade de Salvador.

Como então atribuir uma conexão a estes episódios dentro do escopo almejado? A autora dá a pista: "tentei elaborar um texto como quem monta um mosaico, recompondo informações e buscando organizá-las de modo a construir imagens de uma sociedade imersa em uma crise e, portanto, marcada por conflitos e contradições" (ALBUQUERQUE 2009, p. 43). Desse excerto, percebe-se o caráter transformador da pesquisa, que não se limita a extrair dos vestígios um sentido, mas sim um discurso, naquilo que Certeau nomeia de articulação natureza-cultura. Logo, o historiador interage no processo de seleção, de corte e descarte documental para ressignificar as abordagens que as fontes individualmente indicam e/ou sugerem.

$\mathrm{Na}$ primeira parte do primeiro capítulo, intitulado "Cônsules, doutores e os 'súditos de cor preta': razões e ações políticas num processo de racialização", a estruturação das fontes se encontra sustentada pelo itinerário processual do caso envolvendo os já mencionados africanos viajantes. A articulação consciente da historiadora em torno dos precedentes do Conselho de Estado sobre casos supostamente análogos e a trajetória individual de cada um dos seus integrantes - Nabuco de Araújo, Visconde de Jequitinhonha e Eusébio de Queiroz - tem o propósito de demonstrar "que os juristas do Conselho de Estado não pretendiam explicitar nenhum critério racial para justificar suas decisões" (ALBUQUERQUE 2009, p. 73). Nesse capítulo, ainda, há menção à heterogeneidade do movimento abolicionista, como demonstram os exemplos de Manoel Querino e Rui Barbosa, os quais possuíam visões identitárias distintas: raças emancipadoras e emancipadas.

O capítulo seguinte, intitulado "'Não há mais escravos, os tempos são outros': abolição e hierarquias raciais no Brasil", trata sobretudo de fontes policiais para narrar o contexto em que se via a sociedade após o advento da lei no 3.353, de 13 de maio de 1888 - a Lei Áurea. Nesse ponto, a própria historiadora demonstra sua atitude proativa na delimitação documental, considerando seu escopo central de evidenciar de que forma a sociedade pósabolição se apercebia, considerando, claro, as questões raciais: 
[...] [d]iante desse tabuleiro de infindáveis possibilidades preferi me concentrar no que de fato interessava para o argumento do livro, quer seja, se eram consideradas plausíveis as queixas e inseguranças das autoridades policiais e administrativas. Isso quer dizer que não parti para apurar até que ponto todas as denúncias de desordens provocadas pelos "emancipados" tinham fundamento. Tampouco contabilizei quantos homens e mulheres de cor - trezes de maio ou não - atentaram contra a vida dos seus ex-senhores - brancos ou não. O fundamento que importava para minha tese era o da legitimidade daquele discurso que creditava qualquer exaltação popular ao fim da escravidão, ao desmantelo da ordem sustentada nas relações de subalternidade dadas pelas condições de escravo e senhor (ALBUQUERQUE 2011, p. 291).

Já no terceiro capítulo, "Divergências políticas, diferenças raciais: Rui Barbosa e Guarda Negra", a historiadora enxerta significados de um documento apócrifo que descreve o episódio da vinda do republicano Silva Jardim a Salvador em 1889. A carta anônima a Rui Barbosa é integrada por outras fontes, tais como as memórias de Silva Jardim e Rui Barbosa, além de jornais da época. 0 conjunto dessa coleção remonta o episódio denominado o massacre do Taboão e conduz à ideia lançada por Albuquerque de que os antagonismos partidários foram forjados por critérios racializantes, embora deixe evidenciado que a separação entre brancos e negros não consegue traduzir a complexidade dos diversos posicionamentos políticos da época.

O último capítulo da obra, "Esperanças de boas venturas: as Áfricas recriadas na Bahia", também serve como demonstração da interferência da historiadora nas escolhas e recortes documentais. Após trazer elementos em torno de agremiações carnavalescas negras em Salvador e seus desfiles no final do século XIX, Albuquerque nos apresenta os estudos de Nina Rodrigues e Manoel Querino e, ao entrecruzar tais fontes, argumenta que ambos possuíam representações distintas sobre a apropriação das heranças africanas e tradução da cidadania negra por parte das referidas escolas de carnaval (ALUBQUERQUE 2009, p. 224).

Exemplos como estes reforçam a noção de envolvimento do historiador nas escolhas de documentos aparentemente díspares e não intrinsecamente vinculados de modo a reuni-los e, em seguida, conferir-Ihes uma inteligibilidade na narrativa. O historiador transforma os vestígios em objetos de valor. Embora os relatos em si mesmos não apresentassem explicitamente qualquer menção ao forjamento de identidades raciais, é a historiadora que propõe este enfoque, e, a partir dessa hipótese, sugere uma forma poiética de ressignificação das fontes, mas dentro do limite material destes vestígios.

Como já mencionado anteriormente, a contribuição de cada estudo sobre o passado representa um avanço argumentativo num conjunto historiográfico precedente, um verdadeiro desvio de modelo proposto por Certeau (2015, p. 77), em que o historiador não busca mais levantar questões totalizantes, mas pontuar a construção historiográfica que lhe é anterior, visando a novas direções a esta edificação. A busca pela síntese, outrora o ápice de uma pesquisa, é, atualmente, o seu ponto de partida. Por essa razão, os atuais estudos são voltados para questões marginais porque partem da totalidade para inseri-los. 
A própria estrutura do trabalho em análise, exposto em três grandes eventos, não possui uma associação explicita entre si. Não foram os documentos por si mesmos, portanto, que nortearam a historiadora; foi ela que priorizou determinadas fontes (jornais, livros, documentos oficiais, poesias) para, nessa extensão, constituir um corpus que lhe permitisse discutir o processo de conformação da sociedade pela racialização das relações sociais. E, ao apresentar esta nova categoria sociológica, Albuquerque entra em diálogo direto com historiadores americanistas que analisam a questão da raça como elemento central da estrutura social dos Estados Unidos. Sua obra, portanto, é mais um passo diante das reflexões estabelecidas por Robert Miles, Rebeca Scott e Barbara Fields sobre a questão racial, tendo como enfoque sua historicização no Brasil do final do século XIX (ALBURQUERQUE 2009, p. 35).

A prática historiográfica, contudo, não se limita à atividade de redistribuição e ressignificação das fontes, nem de contribuição pontual. Conforme alerta Certeau $(2015$, p. 85$)$, as mudanças funcionais da História promoveriam novas formas de compreender o processo de conhecimento histórico. A construção de identidades e, em consequência, de categoriais sociais pelo manuseio do discurso racial representa a personificação da própria linha de pesquisa na qual a historiadora esteve inserida (História Social da Cultura) durante a pesquisa que resultou na tese ora em discussão. ${ }^{13}$ Logo, faz todo sentido a proposição da autora de analisar o desenvolvimento de enquadramentos e funções de diversos atores sociais pelo viés da racialização dentro do campo de pesquisa desenvolvido pela Unicamp. E, ao assim fazê-lo, realiza uma reelaboração, no âmbito historiográfico, do conceito cultural e antropológico de raça, o que denota - embora não haja menção expressa nesse sentido - a função da História do trabalho sobre o limite, de modo a torná-la verdadeira instância reflexiva e validadora de categorias de outras ciências.

Todas estas questões associadas à pesquisa refletem, também, na necessidade de criação de novos pressupostos e/ou postulados ao conhecimento histórico (CERTEAU 2015, p. 85-89). Compreendo que a mudança da visão teleológica tradicional para uma visão negativa desloca o sentido e a direção da História. A construção outrora de um dever-ser é alterada para um desvio de sentido, de caráter negativo, não necessariamente vocacionado a uma única orientação. Com efeito, Sousa (2011, p. 186) alerta que o enaltecimento a objetos de estudo particulares não exclui a necessária conexão com as questões gerais estruturantes.

A proposta de Albuquerque de analisar o processo histórico de constituição da raça em toda sua complexidade na cidade de Salvador no final do século XIX, ultrapassando a visão dicotômica birracial, traduz essa nova função da História, que se opõe a um caráter finalístico e generalizante: "[a]ssim, o que me interessou foi como aquela sociedade convulsionada por graves mudanças

\footnotetext{
13 Essa linha de pesquisa é integrante da área História Social. Em apertada síntese, a História Social da Cultura analisa as questões derivadas da sociedade dentro de uma perspectiva cultural dos seus atores. Para maiores esclarecimentos, ver o sítio da Unicamp: http://www.ifch.unicamp.br/ifch/pos/historia/0/296/ linhas-pesquisa.
} 
políticas e culturais preencheu o conceito de raça com significados próprios, trazidos à baila em diferentes ocasiões" (ALBUQUERQUE 2011, p. 292). O acervo documental em si mesmo apenas oferece a fluência dos eventos. Ao historiador caberia estabelecer induções dos casos singulares ao contexto que o cerca, tornando esse itinerário ponte para experimentação de novos limites sobre as produções historiográficas pretéritas (CERTEAU 2015, p. 87).

A obra de Albuquerque é repleta de exemplos de possibilidades de expansão dos acontecimentos. A narrativa sobre o não desembarque de africanos no porto de Salvador em 1877 serviu para justificar sua hipótese de que havia um discurso velado e discriminatório pelo Estado brasileiro, isto é, "avaliar em que medida estavam em curso políticas públicas fundadas em critérios raciais" e "como evitar que pessoas de cor imigrassem para o Brasil sem lançar mão de uma legislação racista?" (ALBUQUERQUE 2009, p. 38 e p. 66, respectivamente). Diante do desfecho tomado pelo Conselho de Estado em não permitir o desembarque dos dezesseis africanos comerciantes, a historiadora levanta uma série de outras problematizações subjacentes ao escopo de sua tese central: a existência de um circuito transatlântico comercial e cultural entre a África e o Brasil, o interesse mercantil da Inglaterra no desenvolvimento desta circulação e a omissão velada e deliberada de manutenção da precariedade da liberdade dos negros.

Se existe interferência direta do historiador sobre o acervo documental, e considerando que as novas peculiaridades do conhecimento histórico acima ventiladas também interferem neste processo de pesquisa, Certeau extrai de todas estas questões pressupostas que o caráter ambivalente do passado e do futuro irá nortear toda a extensão da prática historiográfica. Haveria, assim um caráter dúplice da História, porquanto a prática não só atualiza o passado como também oferece respostas a um futuro, embora o modo como essas assertivas serão mensuradas depende do caráter conservador ou utópico do historiador (CERTEAU 2015, p. 86). Dito de outra forma, a pesquisa histórica pressupõe a presentificação do passado, atualizando as carências de um futuro possível. Essa característica de inserção do passado pelo historiador, que se convertem em expectativas, dará o tom da pesquisa e, por conseguinte, da narrativa.

Nesse ponto, não se pode desconsiderar a questão racial como um legado de experiência traumática em nossa sociedade. Não por acaso, a perspectiva de ruptura de Albuquerque (2016) revela a forma como operacionalizou sua pesquisa sobre a construção da noção de raça em nosso país:

[...] [a] questão da identidade é uma demanda derivada de uma sociedade muito racializada, onde o racismo ainda pauta a vida cotidiana. Será incrível quando negros, indígenas, discutirem questões totalmente diferentes deles, como astrofísica. De que forma isso irá impactar um historiador negro que não discute raça? [...] Isso ainda não é possível porque a questão racial ainda é muito dolorida, ainda é uma ferida aberta. Por isso que todos que participam entram nessa discussão, mas eu tenho a esperança de que haverá um tempo em que você não precise dizer: aquele historiador negro [...]. Nisso tem uma utopia de buscar um mundo melhor para todos, mas acho isso possível. Por isso o desejo, utópico, é que isso [a questão racial] pouco importe (ALBURQUEQUE 2016). 
A percepção do ambiente que a cerca serve de mola propulsora no seu espectro de atuação como pesquisadora. Os recortes temporais (período emancipacionistas e pós-abolição), a formulação de um determinado objeto de pesquisa (conferir historicidade à questão racial) e as fontes utilizadas (registros policiais, processos judiciais, jornais, legislação, literatura, testamentos e documentos oficiais) escapam seu vislumbre utópico. Problematizar e estabelecer uma historicidade à raça no Brasil reflete a compreensão e a dimensão que o conhecimento histórico pode proporcionar para Albuquerque.

A pesquisa acadêmica, portanto, pode ser dissecada a partir do texto produzido, mediante seu descortinamento em etapas e procedimentos analíticos.

\section{A performance discursiva: o texto histórico}

O elemento textual, apesar de consistir na última etapa da operação historiográfica, é sintomático pela coalizão entre o lugar social e as práticas de desvio (CERTEAU 2015, p. 89). Dito de forma sequencial, a escrita histórica seria o início do fim de uma pesquisa, é dizer, o contraponto dos procedimentos investigativos, numa verdadeira inversão escriturária (CERTEAU 2015, p. 90). Mas, não é só isso. $O$ ato de escrever história se consolida pelo discurso, não necessariamente reflexo da pesquisa. Por isso, mais uma vez, o historiador exerce papel fundamental na operação historiográfica porque irá concretizar suas práticas metódicas e confirmar seu lugar social, produzindo um discurso histórico (CERTEAU 2015, p. 101). Em outras palavras, o texto histórico, pelo seu conteúdo narrativo, acaba por se aproximar da literatura, mas, ao mesmo tempo, se diferencia desta porque essa representação se dá em meio ao seu ambiente social e em seus aspectos práticos (VOIGT 2014, p. 318).

Assim, a narração pode ser vislumbrada como uma construção, e como toda obra pressupõe inclusões e exclusões. A lógica que transparece nesse processo, portanto, é de responsabilidade do historiador. O caráter inovador de Certeau é dissecar o discurso realizado pelo historiador, tornando-o mensurável e, portanto, controlável. Aqui, o caráter "cientifico" já exposto na primeira seção deste trabalho se apresenta em sua plenitude.

Certeau define o discurso histórico como uma associação entre narrativa e discurso lógico, de modo que a sucessão temporal arbitrariamente estabelecida pelo historiador é enquadrada dentro de um silogismo (2015, p. 100). Assim, o discurso histórico seria a projeção de um sequenciamento temporal para um encadeamento lógico-silogístico, por meio de um deslizamento metafórico, entendido como "uma passagem de um gênero a outro" (CERTEAU 2015, p. 100). Posso, assim, sistematizar esse procedimento da seguinte forma: 
Figura 1 - A construção desdobrada (primeiro aspecto)

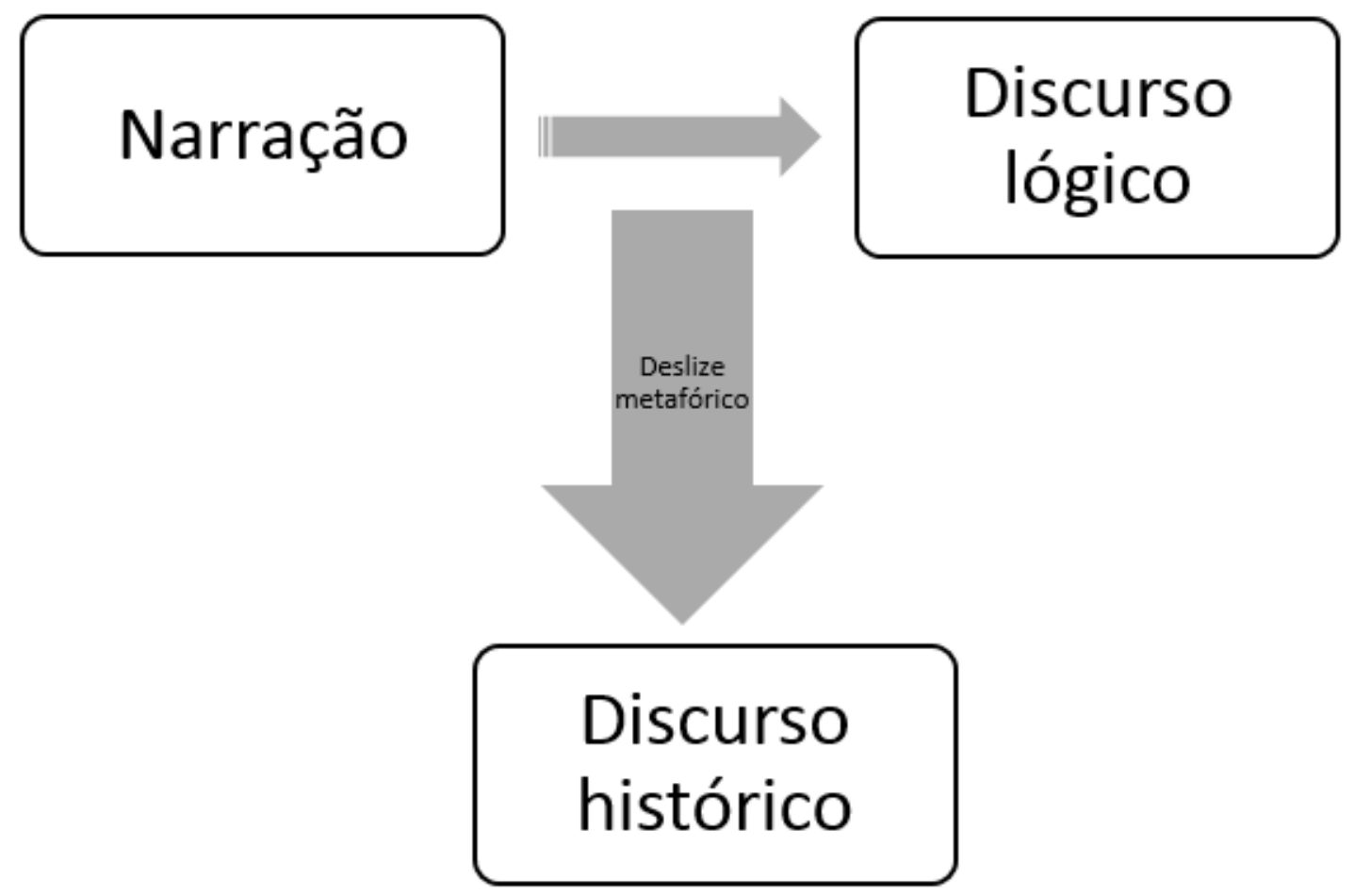

A narrativa, aqui considerada como uma sucessão arbitrária de eventos, é metaforicamente desviada por explicações indutivas ou dedutivas, como 90 um silogismo retórico. o historiador utiliza, portanto, a verossimilhança como instrumento dessa transmudação de discursos. Este ato complexo - resultante do discurso histórico - não se faz sem perda de autoridade, a não ser que, conforme preceitua Certeau (2015, p. 101), seja restabelecida a credibilidade através de uma citação, documental ou por referências de outros historiadores. Ademais, esse diálogo entre o historiador e o leitor se dá por meio de um contrato enunciativo (CERTEAU 2015, p. 103), isto é, o estabelecimento de um vínculo entre as partes, calcado na confiabilidade gerada pelo uso de fontes.

Traçadas essas linhas gerais, creio que já seja possível vislumbrar tais aspectos em trechos da obra ora em estudo.

No primeiro capítulo da obra, há o estabelecimento de uma ordem cronológica e linear, porém desmembrada. A cada etapa sequencial dos episódios, Albuquerque introduz personagens, estabelece inferências e recorre ao argumento de uma autoridade (interpretação prévia de historiadores sobre casos análogos). De forma ilustrativa, , após descrever o contexto social em 1877 e inserir o leitor no universo dos africanos comerciantes que tentavam desembarcar em Salvador, faz remissão ao Conselho de Estado, órgão que analisaria o incidente diplomático envolvendo esses súditos de cor preta: "o desfecho da empreitada dos comerciantes retornados estava à mercê das considerações desses estadistas do Império. Dito isso, pode-se deduzir que o parecer do Conselho em relação à presença dos dezesseis africanos seria, como de fato foi, decisivo" (ALBUQUERQUE 2009, p. 66). 
Nesse momento, a historiadora estanca o desenrolar dos acontecimentos e analisa a trajetória de cada um dos integrantes da referida comissão (Visconde de Jequitinhonha, Eusébio de Queiroz e Nabuco de Araújo), demonstrando que o perfil de cada um deles se voltava para discussões sobre o fim do tráfico e da escravidão. Em seguida, de modo a ratificar seu recorte documental voltado para a forma que tais integrantes do referido órgão imperial iriam decidir o caso concreto, a autora se vale das análises da historiadora Célia Marinho (1994) sobre a diversidade discursiva abolicionista nos Estados Unidos e no Brasil para reforçar e legitimar seu argumento de que "naquele contexto de crise do escravismo, acentuava-se a imagem de brandura das relações entre senhores e escravos no Brasil, na qual não se admitiam restrições construídas sob critérios raciais" (ALBUQUERQUE 2009, p. 73).

Toda essa construção narrativa conduz o leitor a se convencer de que a decisão do Conselho de Estado seria de impedir o desembarque dos africanos sem utilizar fundamentos raciais. Sendo assim, no já avançado discorrer argumentativo, Albuquerque lança a seguinte assertiva:

[...] [n]essa atmosfera de embates entre considerações diplomáticas, convicções ideológicas, silêncios ditados pela política e interesses comerciais, espero já tê-los convencido de que o destino dos africanos do navio Paraguassú estava traçado antes mesmo de o caso ser analisado pelo parecerista da comissão (ALBUQUERQUE 2009, p. 77).

Entre a narrativa do episódio e as conclusões silogísticas decorrentes da exposição argumentativa, Albuquerque precisou introduzir elementos de coesão, dando confiabilidade às exposições, a exemplo de citações de outros historiadores que já haviam interpretado casos concretos similares. Dessa forma, perante acontecimentos aleatórios, a historiadora fornece uma organização temporal e estabelece uma inteligibilidade, atribuindo-lhes, pois, um significante possível. Dessa operação, nasce o fato histórico (CERTEAU 2015, p. 104).

É por este motivo, pois, que Certeau entende todo esse imbricado procedimento como uma construção desdobrada, porque compreende o discurso histórico como o sincretismo de uma sucessividade temporal como métodos de dedução e indução, permeados de discursos de autoridade, de forma a alçar um simples evento à categoria de fato histórico.

Para Chartier (2015, p. 15), essa estrutura mista teria uma tripla função: "convocar o passado que já não está num discurso no presente; mostrar as competências do historiador, dono das fontes; e convencer o leitor". 
Figura 2 - A construção desdobrada completa

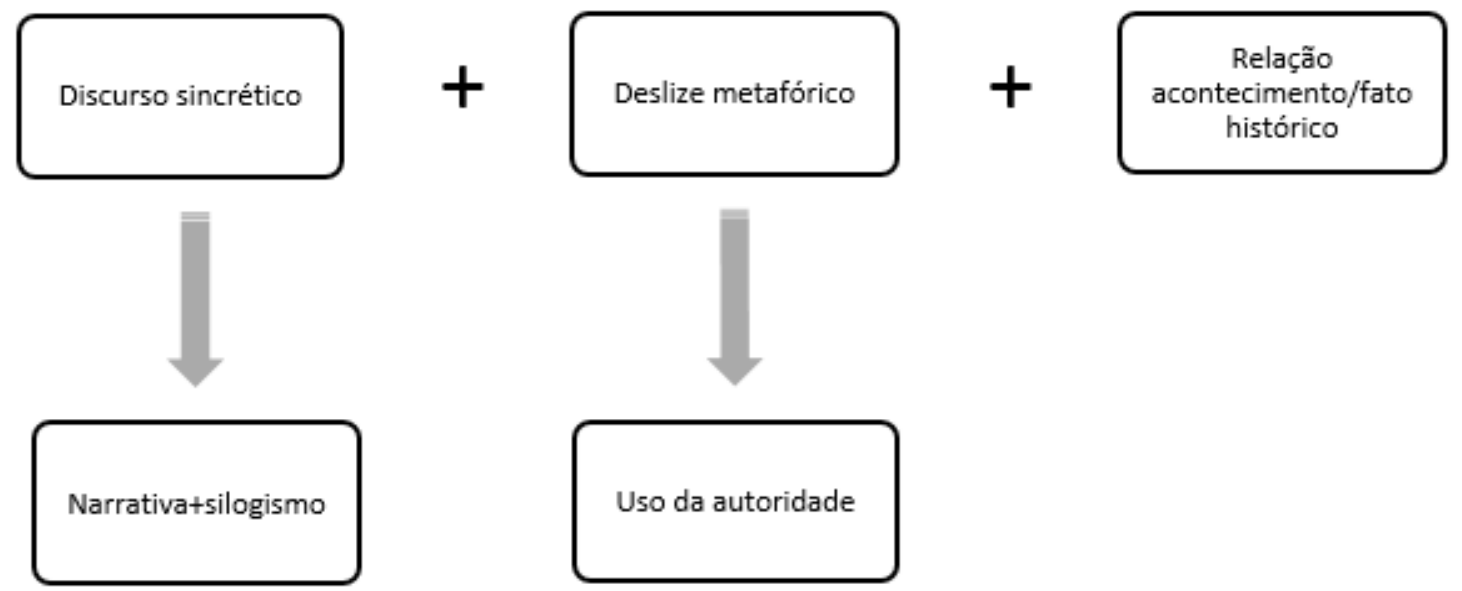

Aplicando esta técnica, verifico que em várias passagens do primeiro capítulo do livro $O$ jogo da dissimulação os documentos não dão conta de explicar o episódio narrado (não há notícias do interrogatório dos africanos, não se sabe o que eles estavam trazendo consigo, inexiste informação do tempo de duração do evento), levando a historiadora a deduzir, pelo contexto social do período (1877), que se tratavam de comerciantes com fluência em inglês e português e que não eram objeto de reescravização. ${ }^{14}$ Como reforço argumentativo e de credibilidade, utiliza não só fontes oficiais e processos judiciais sobre situações semelhantes, como também interpretações de outra 92 historiadora, Manuela Carneiro da Cunha (1986) que já havia analisado o universo comercial e cultural entre Lagos, na África, e Salvador, no Brasil. Por fim, diante de um simples evento (um caso judicial envolvendo a tentativa de desembarque de africanos), a historiadora Wlamyra Albuquerque imprime um sentido, sob o viés de sua hipótese fulcral (a racialização das relações sociais), e, assim, eleva-o ao estatuto de fato histórico por se tornar aspecto que justifica o suporte hipotético (CERTEAU 2015, p. 104) anteriormente lançado: a omissão deliberada do Império em não explicitar que critérios raciais pautavam as decisões do Estado brasileiro.

Dentro desses aspectos discursivos apresentados por Certeau, a questão do deslize metafórico parece exigir também ao historiador um esforço em tornar inteligível a narrativa. Essa hipótese remeteria à necessidade de manuseio de recursos estilísticos como meio hábil de tornar mais próximo e íntimo o diálogo entre o interlocutor e o leitor.

Nesse contexto, a obra em destaque contém uma narrativa clara, acessível, inclusive com tom cinematográfico que convida o leitor a se enveredar nos meandros discursivos sem aperceber tratar-se de um texto acadêmico. Por essa razão, a historiadora esclarece que, embora não intencional, esta habilidade

${ }^{14}$ As possíveis lacunas documentais não impedem o caráter construtivo do historiador. Nesse sentido, conferir a noção de trama em Veyne (1971). 
textual deriva de uma estética inaugurada pelo historiador João José Reis, ${ }^{15}$ que se vale da concepção de que a produção historiográfica é, antes de qualquer questão teórico-metodológica, um contar estórias:

[...] o grupo de escravidão é muito marcado pela narrativa de João Reis. A questão do texto compreensível, a escrita fluida, que pudesse ser lida pelo público em geral. Isso tem muito de um discurso literário, da disposição em escrever uma literatura histórica que facilitasse o acesso do leitor aos seus argumentos. [...] Nessa narrativa sempre há sugestão de literatura, menção de casos, como uma história possível de ler num bar (ALBUQUERQUE, 2016).

A título de exemplo, elenco trecho em que Albuquerque remonta o episódio cunhado de "o massacre do Taboão":

[...] [à]s nove horas da manhã do dia 15 de junho de 1889, era indisfarçável a tensão na cidade. Nosso informante havia pouco saíra de casa com a firme intenção de convencer os três filhos a retornar o mais cedo possível. Ele queria afastá-los da recepção a Silva Jardim, o mais radical propagandista do Partido Republicano que, vindo da Corte, estava prestes a aportar na Bahia. [...] Ao subir a ladeira do Taboão, uma das vidas de ligação entre as partes alta e baixa da cidade, o autor da carta a Rui pôde ouvir uma 'uma gritalhada infernal, gemidos ais e vozes' que diziam: 'mata, mata, mata republicanos, mata Silva Jardim, viva a Monarquia, viva o coronel Santos Marque, viva o partido liberal'. (ALBUQUERQUE 2009, p. 142-143).

Além da característica peculiar da narrativa histórica acima mencionada, Certeau também acrescenta característica singular de descrição do passado: o estabelecimento de uma cronologia ontologicamente não ocorrida (CERTEAU 2015, p. 93-99). O historiador, ao construir um sentido e uma direção aos eventos, estabelece uma temporalização falsificada, mediante o manuseio de personagens como álibi narrativo.

$\mathrm{Na}$ obra em debate, todos os engendramentos dos acontecimentos estão dispostos numa linha de tempo imaginária: é marcando o início da narrativa em 1877, passando pelo ano de 1888 no período do fim da abolição, desaguando em 1897, momento em que analisa os desfiles carnavalescos (ALBUQUERQUE 2009). Conforme anteriormente ventilado, a linha mestra que conduz a narrativa, de natureza linear, é permeada pelo exercício de introdução de personagens como instrumento indutor de raciocínio, mas sempre tendo como elemento norteador um eixo central (que seria uma linha de tempo imaginária). Logo, tanto o sentido como a direção da narrativa é conduzida pela historiadora.

O discurso histórico, portanto, apesar de perfomativo, não é um ato arbitrário. Reconhecer a natureza literária da narrativa não impede que esta seja controlada. Os postulados elencados por Certeau em relação à escrita permitem que tal tarefa seja exequível. 


\section{Considerações finais}

O historiador, ao produzir um discurso expresso em texto, se transforma num exorcista e, também, num visionário: exerce um sepultamento dos mortos, reintroduzindo-os ao presente, de modo a restabelecer um diálogo provocativo e supostamente perdido entre o atual contexto social e o passado (CERTEAU 2015, p. 109).

A trajetória de Albuquerque é composta desta complexa e entrelaçada articulação de narração do passado e estabelecimento de pontes a futuros possíveis. Sua obra acadêmica não se restringe a um novo olhar para o que aconteceu, mas, também, amplia perspectivas, sem perder o ofício de historiadora. Refletir sobre as questões derivadas da escravidão, historicizar a questão racial e buscar compreender os arranjos sociais na Bahia do final do século XIX instrumentalizam e conferem arcabouço teórico capaz de construir projetos nacionais que mitiguem problemas sociais graves em nosso país. Se Wlamyra Albuquerque, como mulher, negra e historiadora, é demandada a responder anseios sociais, ela não se esconde: pelo contrário, devolve-os não só com problematizações e novas abordagens de estudo sobre o passado, mas, também, com propostas que reverberem sua produção historiográfica.

A título de exemplo, Albuquerque integra comitê para ampliação das ações afirmativas na Universidade pública no âmbito da pós-graduação da Universidade Federal da Bahia para, assim, citando a Portaria no 132/2016, de 27 de setembro de 2016, publicado pelo Gabinete da Reitoria da Universidade Federal da Bahia,

94 permitir "à universidade expressar melhor a diversidade étnica, racial, de gênero e de portadores de deficiência existente em nossa sociedade". Trata-se de mais uma contribuição no fazer historiográfico que ultrapassa o elemento textual, mas não perde a essência do discurso histórico.

\section{Referências bibliográficas}

ALBUQUERQUE, Wlamyra R. de. O jogo da Dissimulação: abolição e cidadania negra no Brasil. São Paulo: Companhia das Letras, 2009.

ALBUQUERQUE, Wlamyra R. de. Réplica - O jogo da dissimulação: abolição e cidadania negra no Brasil. Perseu - História, Memória e Política, ano 1, n. 7, p. 288-297, 2011.

ALBUQUERQUE, Wlamyra R. de. Depoimento. Entrevista concedida a Rômulo Gonçalves Bittencourt. Salvador, 7 de out. 2016.

ALBUQUERQUE JR., Durval Muniz. O Tecelão dos Tempos. O historiador como artesão das temporalidades. In: NEGRO, Antônio; SOUZA, Evergton S.; BELLINI, Lígia. Tecendo Histórias. Espaço, política e identidade. Salvador: EDUFBA, 2009a, p. 14-24.

ALBUQUERQUE JR., Durval Muniz. Domingos Sodré, um sacerdote africano: escravidão, liberdade e candomblé na Bahia do século XIX, de João José Reis. Revista Brasileira de História, v. 29, n. 57, p. 211-217, 2009b. 
AZEVEDO, Célia Maria Marinho de. Abolicionismo e memória das relações sociais.

Estudos Afro-Asiáticos, v. 26, p. 5-19, 1994.

BRASIL. Portaria no 132/2016, de 27 de setembro de 2016. Elaboração de proposta de política de Ações Afirmativas para a Pós-Graduação da UFBA. Gabinete da Reitoria da Universidade Federal da Bahia. Palácio da Reitoria, Salvador, 27 de setembro de 2016. Disponível em: https://www.ufba.br/noticias/ reitoria-institui-comiss $\% \mathrm{C} 3 \% \mathrm{~A} 30$-para-discutir-a\%C3\%A7\%C3\%B5esafirmativas-para-p\%C3\%B3s-gradua\%C3\%A7\%C3\%A3o. Acesso em: 19 de outubro de 2016.

BRITO, Ênio José da Costa. O jogo da dissimulação: Abolição e cidadania negra no Brasil, de Wlamyra R. de Albuquerque. Rever - Revista de Estudos da Religião, v. 11, n. 1, p. 209-215, 2011.

COWLING, Camillia. O jogo da dissimulação: Abolição e cidadania negra no Brasil, de Wlamyra R. de Albuquerque. Revista Mundos do Trabalho, v. 3, n. 5, p. 327-329, 2011.

CERTEAU, Michel de. A escrita da história. 3. ed. Rio de Janeiro: Forense, 2015.

CHARTIER, Roger. A história ou a leitura do tempo. 2. ed. Belo Horizonte: Autêntica, 2015.

CUNHA, Manuela Carneiro da. Antropologia do Brasil: mito, história e etinicidade. São Paulo: Brasiliense, 1986.

DOMINGUES, Petrônio. A cidadania Negra. O jogo da dissimulação: Abolição e cidadania negra no Brasil, de Wlamyra R. de Albuquerque. Projeto História, n. 42, p. 421-437, 2011.

FICO, Carlos; POLITO, Ronald. A história no Brasil (1980-1989). Elementos para uma avaliação historiográfica. Ouro Preto: Ed. UFOP, 1992.

KRAAY, Henrdik. Algazarra nas ruas: comemorações da independência na Bahia (1889-1923), de Wlamyra R. de Albuquerque. História Social, n. 8/9, p. 255-259, 2001/2002.

LIMA, Henrique Espada. O jogo da dissimulação: Abolição e cidadania negra no Brasil, de Wlamyra R. de Albuquerque. Perseu - História, Memória e Política, v. 4, p. 247-253, 2009.

GOMES, Tiago de Melo. Dissimulação e outros jogos. Tempo - Revista do Departamento de História da UFF, v. 15, p. 239-244, 2010.

GUIMARÃES, Antônio Sérgio Alfredo. Raça, cor da pele e etnia. Cadernos de campo, n. 20, p. 265-271, 2011.

OHARA, João Rodolfo Munhoz. A história como heterologia: do conceito de História em Michel de Certeau. Dissertação (Mestrado em História) Departamento de História, Universidade Estadual de Londrina, Londrina, 2013. 
ORELLANA, Rodrigo Castro. Michel De Certeau: História e ficção. Princípios Revista de Filosofia, v. 19, n. 31, p. 5-27, 2012.

PEREIRA, Ana Carolina Barbosa. Que objetividade para a ciência da história? O Índio Brasileiro e a Revolução Francesa à luz da teoria da história, de Rüsen a Hayden White. Dissertação (Mestrado em História) Departamento de História, Universidade de Brasília, Brasília, 2007.

RÜSEN, Jörn. Razão histórica. Teorias da história: os fundamentos da ciência histórica. Brasília: Editora da UnB, 2001.

SCHWARTZ, Stuart B. Escravos, Roceiros e Rebeldes. Bauru: Edusc, 2001.

SOUSA, Francisco das Chagas de Loiola. Diálogos com Michel de Certeau sobre pesquisa nas ciências humanas. Revista Crítica Histórica, ano 2, n. 3, p. 181-194, 2011.

VOIGT, A. F. História e Representação: a abordagem de Jacques Rancière. Revista de Teoria da História, v. 11, p. 308-336, 2014. 


\title{
Por uma teoria da modernidade em Poesia Ingênua e Sentimental
}

\author{
For a theory of modernity in On Naïve and Sentimental Poetry
}

\author{
Géssica Góes Guimarães Gaio \\ gessicagg@yahoo.com.br \\ Professora Adjunta \\ Universidade do Estado do Rio de Janeiro \\ Avenida Doutor Mário Guimarães, 1118, apt. 1310, Centro \\ 26255-230 - Nova Iguaçu - Rio de Janeiro \\ Brasil
}

\begin{abstract}
Resumo
Poesia Ingênua e Sentimental figura atualmente como uma das reflexões mais instigantes do poeta alemão Friedrich Schiller. Embora o dramaturgo tivesse como interesse imediato ponderar acerca das formas de sentir e produzir o belo, sobretudo, na poesia e na dramaturgia, o impacto que o texto causou em sua própria comunidade intelectual e a recepção destas ideias ao longo dos séculos XIX e XX o tornaram significativo para investigar o conceito de história que permeava o debate estético, bem como analisar a construção da identidade moderna no bojo deste processo histórico. O objetivo deste trabalho consiste em analisar o tratado estético de Schiller tencionando compreender como sua proposta é constituinte de uma experiência temporal notadamente moderna; assim como ponderar acerca de sua contribuição para a construção da identidade do homem moderno e investigar sua relação e influência em um ambiente cultural no qual a criação intelectual era cada vez mais associada a um procedimento reflexivo.
\end{abstract}

\section{Palavras-chave}

Modernidade; Historiografia; Clima histórico.

\begin{abstract}
On Naive and Sentimental Poetry currently figures as one of the most intriguing reflections of the German poet Friedrich Schiller. Although the dramaturge had the immediate interest of considering the forms of feeling and producing beauty, in particular on poetry and theater, the impact of this treatise on its own intellectual community and the reception of these ideas throughout the nineteenth and twentieth centuries made it meaningful to investigate the concept of history coetaneous to that aesthetic debate and to analyze the construction of the modern identity in the midst of this historical process. This work aims to analyze Schiller's aesthetic treatise looking forward to understand how his proposal is part of a typically modern temporal experience; as well as to concern about its contribution to the construction of the identity of this modern man and to investigate its relation and influence in a cultural atmosphere in which the intellectual creation was increasingly associated to a reflexive procedure.
\end{abstract}

\section{Keywords}

Modernity; Historiography; Historical atmosphere.

\section{Recebido em: 23/9/2016}

Aprovado em: 3/5/2017

* Esta pesquisa recebeu financiamento concedido pela Capes. 


\section{Schiller e o "Outro"}

Como é que, sendo em tudo o que é natureza infinitamente suplantados pelos antigos, podemos justamente aqui homenagear a natureza num grau mais elevado, apegar-nos a ela com afeição e mesmo abraçar o mundo inanimado com a mais calorosa sensação? (SCHILLER 1991, p. 55)

Poesia Ingênua e Sentimental ${ }^{1}$ foi publicado pela primeira vez como artigos separados na revista Die Hören, entre 1795 e 1796. Posteriormente, cerca de quatro anos mais tarde, Schiller providenciou a sua publicação conjunta, cuja organização e conteúdo chegaram até nós. A influência desse texto na vida intelectual da Alemanha, na passagem dos setecentos para os oitocentos é notória, e sua recepção ao longo da tradição literária e intelectual ocidental já figurou como matéria de interesse para inúmeros germanistas, com destaque para os trabalhos de Peter Szondi e Hans Robert Jauss (SHARPE 1995). Não obstante, este ainda se mantém como um dos trabalhos mais estimulantes de Schiller, sobretudo pela complexidade das categorias propostas no ensaio e sua conexão tão íntima com o contexto intelectual no qual foi produzido.

Especialmente em território brasileiro, este trabalho ainda merece atenção, e nos interessa exatamente uma reflexão acerca da relação entre as ideias ali apresentadas e o debate intelectual de sua época - para além de sua contribuição para a caracterização da poética clássica e da romântica -, a fim de investigar a respeito da concepção de história, de homem e de modernidade que Schiller formulou em embate com sua própria experiência. Embora não se trate de um texto historiográfico tout court, ainda assim nos parece pertinente levar a curso a sugestão do historiador brasileiro Valdei Lopes de Araujo a respeito de uma "analítica da historicidade", através da qual as diversas formas de conhecimento do passado devem ser enraizadas no próprio tempo histórico. Sendo assim, é partilhando desta postura analítica que pretendemos trilhar por entre as concepções de arte e de história que movimentaram a reflexão do poeta.

A referência à carta de Goethe a Eckermann, em 21 de março de 1830, nos parece incontornável para iniciar a reflexão:

O conceito de poesia clássica e romântica, que agora corre o mundo todo e causa tanto conflito e divergência, provém originalmente de mim e de Schiller. Na poesia, tinha eu por máxima o procedimento objetivo e pretendia que apenas este valesse. Schiller, porém, que atuava de forma inteiramente subjetiva, considerava a sua maneira a correta, e para defender-se de mim, escreveu o ensaio sobre poesia ingênua e sentimental. Demonstrou-me que eu próprio, contra a vontade, sou romântico e que, pelo predomínio da sensibilidade, minha Ifigênia não é assim tão clássica e tão no sentido antigo como talvez se pudesse crer. Os Schlegel aproveitaram a ideia, de modo que agora ela se difundiu pelo mundo inteiro, e todos falam de classicismo e romantismo, nos quais há cinquenta anos ninguém pensava (GOETHE apud SCHILLER 1991, p. 23). 
As palavras de Goethe sintetizam em grande maneira a recepção que as ideias de Schiller encontraram em solo germânico. Fica acentuada aqui, sobretudo, a dicotomia entre clássico e romântico que por muitas décadas forneceram a tônica do debate acerca de PIS. Contudo, mesmo que Schiller tivesse encontrado motivação para buscar tal entendimento em seu relacionamento com Goethe e as diferentes maneiras que encontravam para produzir sua arte, em contrapartida, nos parece que este aspecto não deveria ser maximizado.

O ano do início da correspondência entre Schiller e Goethe foi também o da elaboração dos artigos que deram origem ao Poesia Ingênua e Sentimental. Já na famigerada primeira carta de Schiller a Goethe, de 23 de agosto de 1794, o remetente de Iena traçou o perfil intelectual de seu destinatário destacando sua capacidade em aproximar-se da natureza: "O senhor concentra toda a natureza, a fim de receber uma luz de cada elemento; na totalidade dos fenômenos dela o senhor procura a explicação para o indivíduo". Esse traço do espírito poético de Goethe aguçou o interesse de Schiller, que considerava essa habilidade um verdadeiro dom, o dom do gênio que, inclusive, julgava ausente em sua própria forma de poetizar. Schiller teria ficado maravilhado com a facilidade com que Goethe transformava o complexo em fluidez, como ele era capaz de expressar o absoluto de forma tão simples. Na mesma carta, ele concluiu: "o senhor teve trabalho a mais, pois da maneira como passou da visão à abstração, teve de transpor de volta conceitos em intuições e transformar ideias em sentimentos, pois só através deles o gênio pode produzir" (GOETHE; SCHILLER 2010, p. 28-27).

Essa passagem nos parece central para o entendimento da tese presente nos artigos que compõem PIS. Se por um lado Schiller entende a poesia de Goethe como ingênua, porque preserva uma relação próxima com a natureza, algo que considera incapaz de realizar em sua própria produção artística, por outro não se escusa de enfatizar que esta relação não é imediata, ela não é natural, e sim fruto de um laborioso artifício intelectual - por mais que tal esforço não cause fadiga - de transformar ideias e conceitos em sentimentos e intuições. Isto é, a relação de Goethe com a natureza não era espontânea, não poderia ser, pois seu pertencimento histórico lhe permitia desenvolver primeiramente as capacidades da razão e seu gênio Ihe possibilitou transformálas em forças da natureza.

No conto "Hora difícil", de 1905, um século após a morte de Schiller, Thomas Mann trouxe as inquietações de Schiller de volta à vida. Sua condição enferma, o cansaço de seu corpo debilitado, as modestas instalações de sua casa, as ideias em tempestade e o Outro, aquele que Ihe era tão próximo, mas ainda assim o espelho invertido, a imagem de quem ele jamais fora ou pudera ser, "aquele que amava com terna inimizade". Talvez Poesia Ingênua e Sentimental tenha contribuído para a construção desta imagem: Goethe como o poeta ingênuo e genial, posto que sua arte mantinha uma relação direta com 
a natureza; Schiller como o poeta sentimental, ${ }^{2}$ atordoado, cuja poesia e teatro eram filhos do sofrimento, da dor.

Era preciso afirmar e definir sua própria natureza e arte diante da do Outro. O Outro seria maior? Se fosse, em quê, e por quê? Se vencesse, seria por ter suado sangue? Se perdesse, seria uma queda trágica? Não, o Outro não era herói; talvez um deus. Mas era mais fácil ser deus que ser herói (MANN 2000, p. 202).

Seria mais fácil ser ingênuo do que sentimental? Seriam realmente as duas categorias apenas uma caracterização do modo de Goethe e Schiller sentirem e viverem a arte? Por mais envolvente que seja essa tese, não consiste em nosso interesse sustentá-la. Mais do que sua relação com o amigo de Weimar, importava a Schiller o estatuto de seu tempo, a necessidade de conferir sentido à arte e legitimá-la como promotora da educação do gênero humano.

\section{A Querelle des anciens et des modernes e a consciência do tempo}

Ainda pairava no mundo intelectual europeu do século XVIII o que se convencionou chamar de "querela entre antigos e modernos", uma série de debates que tomaram, principalmente, os salões franceses e cujo tema central era a contenda entre defensores e detratores dos feitos dos antigos e dos modernos. O historiador brasileiro Antonio Edmilson Rodrigues dedicou o último capítulo de Tempos Modernos à análise da "querela", e sua reflexão sobre a construção da ideia de moderno através da elaboração do seu outro como antigo está em acordo com a proposição de Hans Robert Jauss, para quem a querela consiste em um topos literário, que se repete em tentativas periódicas de estabelecer o novo em contraste com o precedente (RODRIGUES; FALCON 2000 , p. 247). Joan DeJean (2005, p. 39), por sua vez, sugere uma analogia entre a querela francesa do século XVII e as guerras culturais no âmbito da literatura norte-americana da década de 1990 para propor uma nova concepção de fin de siécle, na qual seja possível perceber essas disputas entre o novo e a tradição como uma faceta da tensão intrínseca à noção de progresso. ${ }^{3}$

Desde o século XIV, a filosofia humanista atribuiu à Antiguidade uma função modelar na cultura e pensamento europeu; seja através de uma atitude mediada pela imitação, inspiração ou emulação, a Antiguidade Clássica grecoromana exerceu um papel paradigmático para a cultura ocidental. Esse antigo foi convertido em tradição clássica e a construção da modernidade foi forjada em contínua negociação com o legado greco-romano. A ideia de uma tradição conferiu inteligibilidade à produção intelectual e estética dita classicista, bem como tornou inevitável o reconhecimento da grandiosidade dos antigos como

\footnotetext{
2 Schiller usou o termo Sentimentalisch para distinguir o seu sentimental da corrente literária do Empfindsamkeit, "sentimental" no sentido de "emotivo". O termo escolhido por Schiller tem como objetivo afastá-lo da tendência de fins do século.

${ }^{3}$ A autora salienta que mesmo Charles Perrault em seu Parallèle des Anciens et des Modernes compreendeu que seu argumento sobre a superioridade dos modernos apontava para um problema cultural, afinal, o que poderia emergir após a "perfeição"? Ao considerar o seu próprio tempo como o ápice do progresso, Perrault lançava a dúvida sobre os tempos vindouros (DEJEAN 2005, p. 43).
} 
justificativa do desenvolvimento dos modernos. Pensar em uma tradição clássica nesses termos seria pressupor que, independentemente da linearidade, um só tempo envolve as duas pontas do debate.

Na Academia Francesa, em finais do século XVII, Charles Perrault, em Parallèle des Anciens et des Modernes, falava em nome dos modernos e da inegável "lei do progresso intelectual". A grandiosidade dos antigos era atestada por seus inúmeros feitos, mas a superioridade dos modernos poderia ser comprovada pelo simples fato de que os antigos não tiveram antecessores, já os modernos contaram com toda a produção intelectual e cultural da Antiguidade. A metáfora de Bernardo de Chartres dos "anões em ombros de gigantes" ainda era considerada apropriada para ilustrar o respeito que os modernos tinham em relação aos antigos, bem como a certeza da proeminência dos novos tempos. No Século das Luzes, com a materialização do progresso técnico e intelectual na Enciclopédia, os tempos modernos aparentavam aos seus defensores nada menos que uma realidade melhor. A "querela" ganhou uma nuance no século XVIII, pois se $o$ ideal de homem e liberdade que predominou entre os gregos ainda comovia os intelectuais, por outro lado, até que ponto os modernos estavam dispostos a abrir mão do avanço técnico e intelectual que a humanidade havia alcançado? 0 dilema que motivou o ensaio de Schiller estava em estreita conexão com essa pergunta. De acordo com Rodrigues (2000, p. 273), no século XVIII, o debate permaneceu, mas "a vitória dos modernos sem a derrota dos antigos" construiu a base para o progresso iluminista e conferiu sofisticação à produção cultural.

Assim como a Aufklärung, em solo germânico a "querela" chegou um pouco depois de seu début nos salões franceses. Foi somente no último quartel do século XVIII que este debate foi acolhido entre os intelectuais, sobretudo por Herder, Schiller e Friedrich Schlegel. Segundo Maike Oergel, germanista e professora da Universidade de Nottingham, a identidade moderna germânica emerge justamente da definição da modernidade europeia no seio desta disputa com o passado, na qual a "querela" pode ser resumida ao embate entre uma perfeição realizada pelos antigos e o processo de conquista da perfectibilidade pelos modernos.

Oergel nos ajuda a lembrar que a resposta predominante na França para esta questão apontava para uma concepção do tempo histórico como processual e progressista. Entre os alemães, o debate seguiu por outra vereda. Herder, por sua vez, já bastante sensível às ideias que posteriormente seriam denominadas como Historismus, buscou, através de uma perspectiva histórica, uma nova compreensão para a "querela" - pelo menos no que dizia respeito às artes. Segundo sua análise, o belo seria relativo a cada tempo e cultura. Ainda muito influenciado pela Aufklärung, Herder não excluiu de sua noção particularizada do belo a existência do belo universal como um ideal, que demandaria padrões universais e a concepção de que há certa normatividade na natureza humana.

Mas tal definição é problemática mesmo para o filósofo, pois a acepção da "constância da natureza humana" associada a uma medida tipicamente moderna, tal qual o "progresso", seria o suficiente para afirmar a superioridade dos modernos por questões quase que matemáticas. Todavia, o historicismo 
de Herder tende a pensar a mudança de maneira qualitativa, primando pela compreensão das características específicas de cada manifestação cultural, através da concepção da natureza como fonte de criação e espontaneidade para a história (CALDAS 2007, p. 51). Dessa forma, os valores clássicos deixariam de ocupar um lugar absoluto nesta história, bem como a "mudança" em si passaria a ser a principal característica do processo. Diferentemente do que ocorreu na França, Herder, Schiller e Schlegel estavam mais interessados em relacionar antigos e modernos do que confrontá-los.

A contribuição das ideias historicistas para o desdobramento da "querela" entre os alemães não poderia ser obliterada, afinal por intermédio desta nova maneira de se relacionar com o passado que Herder pôde articular sua ideia de belo com o imperativo iluminista do progresso. Seu ideal de beleza poderia ser compreendido como a perfeita particularidade de uma expressão cultural, que mantém até mesmo uma normatividade interna, porém apenas enquanto aquela cultura na qual se insere ainda for orgânica. Toda vez que isso acontecer na história da humanidade, certamente será algo grandioso, e, assim, merecedor de memória e constituinte do ideal que a humanidade deve seguir. O objetivo não seria estabelecer um padrão, mas reconhecer na história a realização de algo essencial, único, filho de seu tempo e, nessas condições, verdadeiro. Por isso, Sófocles e Shakespeare ainda seriam pertinentes, mesmo para uma Europa oitocentista.

A imitação dos gregos seria inútil e esvaziada de sentido, pois ela teria

102 como pressuposto um ideal estático de homem e cultura. Herder rejeita os dois lados da "querela", porque ambos representam pontos de vista a-históricos. Suas ideias apontam para uma perspectiva que não se encerrasse em um passado acabado, ou em um futuro carente de significado, mas no presente e nas necessidades da cultura de um povo.

Para Oergel, quando Schiller e Schlegel encetaram a discussão sobre a relação entre os antigos e os modernos, a partir da segunda metade da década de 1790, o historicismo já se encontrava integralmente presente em seu argumento. O artigo de Schiller estaria, portanto, fundamentado na concepção de que a arte é profundamente diferente em cada período histórico, porque o ambiente histórico e intelectual interfere decisivamente nas condições de sua produção. PIS poderia ser compreendido entre o segundo e o terceiro significados de "moderno" elencados por Gumbrecht (1992, p. 81): a concepção de moderno como "novo" e oposta ao "antigo" e a ideia de moderno como "transição" como um "futuro passado". Sendo assim, a comparação entre antigos e modernos somente seria possível em um nível estrutural, e a essa tarefa Schiller teria se lançado em PIS.

\section{A dialética do ingênuo e do sentimental}

A querela configurou o pano de fundo para que Schiller elaborasse os conceitos de poesia ingênua e poesia sentimental. Todavia, seu objetivo era caracterizar a produção poética através do seu modo de sentir, por isso evitou as denominações clássico e moderno. Sua tentativa era criar algum entendimento 
a partir da concepção de que essas duas maneiras distintas de poetizar são motivadas por formas de sentir também específicas.

De acordo com Schiller (1991, p. 55), a relação dos gregos com a natureza era completamente diferente da moderna, aos gregos "a natureza parece interessar mais seu entendimento e sua avidez de saber do que seu sentido moral; não se apega a ela com afeição, com sentimentalismo, com doce melancolia, como nós outros modernos". Essa diferença é o ponto de partida do ensaio, os gregos - principais representantes do modo de sentir ingênuo teriam como base de sua relação com a natureza o seu amor pelo conhecimento; já os modernos procuravam na natureza uma referência moral, e a percepção do afastamento entre o homem e a natureza produz o sentimento de melancolia que atormentara Schiller e grande parte dos seus contemporâneos. Sua tese sustentava a existência de apenas duas formas de poetizar, e essas duas formas estariam intrinsecamente associadas às duas maneiras distintas de o poeta se relacionar com a natureza - ser natureza ou buscar a natureza perdida -, testemunha ou vingador da natureza.

Lothar Pikulik (2009, p. 81), germanista e professor emérito da Universidade de Trier, propôs um entendimento acerca das categorias empregadas por Schiller através de um movimento analítico que denominou como "dialética do sentimentalismo". Em seus termos, a antinomia entre o ingênuo e o sentimental poderia ser pensada através da dinâmica entre o sentimento da natureza e a desnaturalização do sentimento no fazer poético moderno. Ao historicizar a busca pela natureza como um imperativo para o idealismo alemão em fins dos setecentos, encontraríamos em Jean-Jacques Rousseau uma das mais importantes influências para o trabalho de poetas como Kleist, Klopstock e do próprio Schiller. O retorno à natureza para estes poderia então ser compreendido em compasso com as mudanças na vida de várias sociedades europeias, intensificadas pelo crescimento das cidades e da atividade comercial e manufatureira, o afastamento da vida campesina e a experiência paradoxal da solidão em plena sociedade. Peter Szondi (1991, p. 47) empreendeu uma importante investigação sobre a dialética dos conceitos de ingênuo e sentimental e concluiu que, para Schiller, sentimental não era oposto a ingênuo, uma vez que, na analítica dos conceitos, ingênuo seria contrário ao pensamento reflexionante, e sentimental, o acordo entre a ingenuidade perdida e a razão. Em outras palavras, o sentimental seria o novo ingênuo, mas dessa vez já imbuído de seu ideal.

O que caracterizaria a atitude sentimental seria o interesse do homem moderno pela natureza. Schiller chegou mesmo a afirmar que nossa maneira de nos comovermos com a natureza se assemelharia à sensação de um enfermo em relação à saúde. O emprego de uma metáfora médica é muito interessante, pois denota a aguda insatisfação de Schiller com o seu tempo e sua cultura, mas também seu otimismo pela possibilidade da cura. Igualmente pertinente seria lembrar que no subtítulo de sua tese de doutoramento, Crítica e Crise, o historiador alemão Reinhart Koselleck (1956) se propunha a um estudo sobre a "patogênese" do mundo burguês. Ora, parece que a alegoria do nascimento enfermo da modernidade atravessou a tradição alemã e tornou-se mais uma 
maneira paradigmática de compreender tal processo histórico, sobretudo em oposição a um otimismo quimérico no progresso e na razão que emanava dos salões franceses. O que Pikulik (2009, p. 84) destaca com muita propriedade é que, se para Schiller o homem moderno encontrava-se adoentado, a atitude sentimental face ao mundo e sua arte assumiria certa função terapêutica.

Essa terapia estaria a serviço dos indivíduos que compartilhavam aquela experiência histórica e não apenas aos poetas e artistas. Lothar Pikulik assinala que o conceito de sentimental empregado por Schiller não se reduz à poesia, pois ele teria atribuído-Ihe uma atitude radicalmente transformada do homem civilizado a respeito da natureza, fundada na forma íntima do espírito. Nesse aspecto, a análise do germanista ganha bastante densidade, sobretudo na formulação da tese de que o sentimentalismo seria um "pietismo secularizado", no qual o caráter comum entre o sentimentalismo e o pietismo convergiria no surgimento de uma experiência íntima com o mundo ao redor, por meio da valorização da subjetividade (BERLIN 1997; WEBER 2004).

Nesse movimento de interiorização, seja da experiência religiosa, seja da observação do eu e do mundo, o indivíduo moderno estaria face ao procedimento que o torna sujeito: a autorreflexão. Como consequência direta, a subjetividade passaria a participar diretamente na representação do objeto da observação (ARAUJO 2011). É nessa operação que a experiência da natureza para o poeta sentimental converte-se na experiência de si mesmo. Graças ao caráter reflexivo de sua razão, ao conhecer seu objeto, ao produzir conhecimento, ao criar a arte, o homem moderno se auto-reflete. Neste processo de interiorização, o sujeito transforma-se em espectador de si mesmo.

Para Pikulik, no ensaio Schiller expressava sua crítica e insatisfação com a cultura. Não obstante, se atenuarmos o valor pejorativo que o emprego da crítica contraiu nesta proposição e pensarmos a partir de uma perspectiva na qual a crítica seja o esforço de pensar os limites da razão e do conhecimento, podemos alargar um pouco mais a dimensão do projeto schilleriano. Uma vez que o poeta visava não somente apontar as mazelas de seu tempo, como também indicar caminhos a serem trilhados pelo homem moderno, o seu ensaio adquire contornos de uma crítica de ares kantianos, na medida em que sua avaliação não se restringe ao ateliê do poeta, mas se amplia para as formas de conceber o conhecimento e sua representação nas artes. ${ }^{4}$

Se a modernidade estava enferma, para Schiller a boa saúde poderia ser reestabelecida através da recuperação de um traço ingênuo, de uma reconciliação com a natureza. Sua resposta para a antinomia aparentemente insolúvel entre sensibilidade e espírito seria a conciliação entre ingenuidade e reflexão. O caminho natural da criação na poesia ingênua se oporia ao caráter racional distintivo do processo de modernização, dessa forma, a espontaneidade do poeta ingênuo, da qual flui a beleza em comunhão com a natureza, deveria

\footnotetext{
${ }^{4} \mathrm{~A}$ influência da filosofia de Immanuel Kant sobre o pensamento de Schiller é notável e muito mais ampla do que a referência acima. A Crítica da faculdade do juízo foi central para a formulação dos princípios estéticos da reflexão schilleriana, como, por exemplo, a teoria do sublime. Mas devido às dimensões deste artigo, este ponto não consiste em nossa prioridade.
} 
ser emprestada ao poeta moderno, de maneira que na criação sentimental a beleza pudesse ser resultado da consciência, da razão que transformou a natureza em Ideia. ${ }^{5}$

Para sustentar seu argumento acerca da naturalidade da poesia ingênua, Schiller (1991, p. 51) chegou a afirmar que todo gênio seria ingênuo. O gênio - compreendido como o tradutor da natureza - não poderia travar com ela outra relação se não da ingenuidade. Assim sendo, o gênio seria aquele cuja sensibilidade o torna mais suscetível que os demais homens aos mistérios da natureza. Mesmo ingênuo, o gênio poderia também surgir na modernidade, sendo a melhor chance de a humanidade estabelecer um vínculo verdadeiro com a natureza perdida, entretanto, nem mesmo o gênio estaria imune ao seu tempo, e até mesmo o seu caráter poderia ser corrompido. "Ignorando as regras, essas muletas da fraqueza e mentoras do erro, e orientado apenas pela natureza ou pelo instinto, o seu anjo da guarda, caminha com tranquilidade e segurança por todas as ciladas do falso gosto" (SCHILLER 1991, p. 51); para o gênio, as normas são entraves, na verdade ele as desconhece, pois não carece de medidas para preparar uma bela obra, por isso ignora receitas e desafia os cânones. O gênio é o arauto da natureza não somente porque soluciona o complexo com simplicidade, mas, sobretudo, porque ele o faz com graça - uma leveza de gestos e forma que só o espírito ingênuo seria capaz de expressar.

Já o poeta sentimental tem sua experiência marcada pela ruptura entre o homem e a natureza, ele não pode mais atingir a plenitude do mundo natural, pois sua relação com a natureza foi dissolvida pelo processo civilizador, a cultura é sua cicatriz, lembrando-Ihe frequentemente que a espontaneidade foi perdida, em benefício do desenvolvimento de sua consciência. A naturalidade esvaída foi compensada pela capacidade de reflexão, através da qual o poeta seria capaz de acessar a natureza de maneira ainda mais plena, como uma Ideia. Essa relação subjetiva proporcionaria ao poeta sentimental realizar em sua obra a natureza não como apresentação da realidade, mas como busca de um Ideal. "À medida que a natureza foi, pouco a pouco, desaparecendo da vida humana como experiência e como sujeito (agente e paciente), nós a vemos assomar no mundo poético como Ideia e como objeto" (SCHILLER 1991, p. 56). É essa busca consciente de um Ideal do gênero humano que assegura aos modernos a superioridade, na contenda armada por Schiller.

Na poesia ingênua, a sensibilidade elabora uma imagem da natureza completamente baseada na experiência; já na poesia sentimental, a razão consegue formar um conceito de natureza mediado pela reflexão, este conceito ultrapassa as limitações dos sentidos e se expande no infinito da consciência. Segundo Márcio Suzuki, a poesia sentimental, tal como pensou Schiller, é

\footnotetext{
${ }^{5}$ Erwin Panofsky nos ajuda a historicizar o sentido deste conceito desde sua primeira utilização por Platão, quando a "Ideia" remetia a valores metafísicos e universais, intransponíveis pela obra de arte. Contudo, Panofsky acreditava que ainda na Antiguidade, provavelmente nos trabalhos de Cícero, já seria possível perceber um uso do conceito com a conotação que o aproxima da atividade artística, a saber, como "representações ou intuições que residem no espírito do próprio homem" (PANOFSKY 1994, p. 12). Aqui o conceito de "ideia" é empregado como "conceito da razão", em alusão à apropriação da filosofia de Kant operada por Schiller. Na Crítica do Juízo, Kant explica que os conceitos da razão não podem ser expostos, uma vez que não são frutos da experiência, fenômenos ou mediados por algum objeto, são, portanto, representações de ideias morais.
} 
progressiva, pois seu a priori é o aperfeiçoamento infinito da razão humana, enquanto que a poesia ingênua opera em uma perspectiva de aperfeiçoamento limitada pela finitude da natureza. Para Suzuki (apud SCHILLER 1991, p. 22), o ensaio de Schiller é um elogio ao progresso: "Não é com revolta contra os feitos do entendimento e contra o estado em que se acha a sociedade, mas é progredindo que se recupera a sensibilidade e a verdadeira natureza". ${ }^{6}$

A Ideia de natureza se torna mais complexa e dinâmica do que sua realidade sensível. O poeta sentimental tem em seu benefício a possibilidade de recorrer ao infinito para produzir a sua arte, enquanto a experiência da natureza do poeta ingênuo é limitada. Embora o poeta sentimental saiba que a totalidade é um interdito, ainda assim, mantém o absoluto como sua meta e é dessa busca pelo Ideal que emana a beleza da poesia sentimental. Se a naturalidade das formas e a espontaneidade da expressão caracterizariam o belo ingênuo, a reflexão e a idealização da natureza seriam os traços distintivos da beleza sentimental. Neste momento, configura-se uma inflexão relevante, pois a cultura, que a princípio foi avaliada como a responsável pelo afastamento entre o homem e a natureza, transformar-se-ia em aspecto imprescindível da poesia sentimental e motivo de sua superioridade em relação à poesia ingênua. ${ }^{7}$

\section{O sentimental como uma categoria analítica para a Modernidade}

A categoria "sentimental", proposta por Schiller, nos obriga a pensar algumas questões em torno da cultura burguesa, então em expansão entre os 106 reinos germânicos. Thomas Mann (2012) não encontrou grandes dificuldades ao afirmar o caráter burguês da produção literária de Goethe, e nós também não teríamos maiores constrangimentos em fazê-lo acerca da reflexão teórica aqui analisada. Contudo, foi o próprio autor de A Montanha Mágica quem nos advertiu sobre o seguinte aspecto: Goethe pode ser considerado o grande representante intelectual e cultural do mundo burguês, mas foi Schiller quem entre os alemães melhor apresentou seu ímpeto humanitário-revolucionário. Como um "patriota da humanidade", Schiller representaria o ideário político burguês, sobretudo pelo viés democrático-liberal. Sua inserção na cultura burguesa foi mediada por esse otimismo libertário de viés nitidamente político, mas pouco comprometido com a reflexão social (MANN 2012).

Além da perspectiva política apontada acima, uma segunda característica fundamental do processo de modernização em curso na Europa ocidental, a saber, a racionalização das mais diversas esferas da vida social também configura como um dos principais distintivos da poesia sentimental. O poeta sentimental é consciente de que sua criação é um produto do artifício, produto de uma mente capaz de criar a partir de suas competências cognitivas e de um instrumental conceitual e analítico que o inibe de qualquer espontaneidade,

\footnotetext{
${ }^{6}$ Hans Robert Jauss já havia afirmado anteriormente que Schiller foi o primeiro a conferir um valor positivo à ideia de "moderno" na tradição alemã (OERGEL 2006, p. 28).

7 Schiller (1991, p. 57) destacou que assim como existem poetas modernos que exprimem um sentimento ingênuo em sua arte, alguns poetas antigos também produziram obras sentimentais. Seu principal exemplo é Horácio, considerado poeta de uma época decadente, o qual exaltou a tranquilidade perdida, e que seria o fundador do gênero sentimental.
} 
porém o habilita a superar aquilo que antes era apenas natureza; através do procedimento racional, a poesia sentimental pode produzir o Ideal.

Escusado dizer que tal procedimento se expandiu para além da pena dos dramaturgos. O entendimento de que o trabalho intelectual pressupunha um esforço de universalização se tornara uma assertiva bem-aceita nos mais variados círculos científicos e acadêmicos. O historiador profissional também se apropriou do mesmo discurso para legitimar a disciplina no curso do século XIX, a alegação de um trabalho empírico, confiável, fundamentado em pesquisa rigorosa das fontes e livre das paixões é mais um afluente dessa cultura racionalista e burguesa por excelência. A historiografia que se consolidou nas universidades germânicas no século XIX certamente poderia ser chamada por Schiller de "sentimental". Ela é sentimental na medida em que é artifício, enquanto produto da consciência de sua artificialidade e quando explora as possibilidades e limites de tal conhecimento. ${ }^{8}$

Se entendermos nesses termos a produção historiográfica dos oitocentos, então poderemos compreender que a busca pela cientificidade e imparcialidade não era apenas demanda da estrutura universitária na órbita do modelo das ciências naturais, mas também uma experiência compartilhada de crescente aburguesamento da sociedade e dos padrões de construção dos discursos acerca da realidade, entre eles o discurso sobre o passado. Podemos entender a proposta analítica de Schiller como um sinal de certa sensibilidade acerca do processo histórico no qual ele mesmo estava inserido, destarte, o poeta sentimental seria assim compreendido no bojo do processo civilizador em curso na Europa moderna. ${ }^{9}$ Contudo, a especificidade do olhar do poeta nos proporciona ainda um novo cuidado no trato da questão. A sensibilidade aguçada de Schiller captou um aspecto desta experiência histórica que se tornou muito cara para seu argumento e nos auxilia a compreender a complexidade daquilo que denominamos como modernidade. Ao caracterizar a arte de seu tempo como sentimental, ele não apenas atentava para o caráter racional da obra, como também para a vocação estética dessa produção. Ora, importava a ele entender o papel da imaginação na arquitetura razão humana e ao decidir chamar sua poesia de sentimental interessava-Ihe afirmar a relevância dos sentidos para a compreensão do mundo.

\footnotetext{
${ }_{8}$ Provavelmente o melhor exemplo desta concepção de uma escrita da história sentimental seria o artigo de W. von Humboldt (2001), Sobre a tarefa do historiador, no qual o ofício do historiador é analisado através de sua dupla exigência: o trabalho com as fontes e a interpretação do processo histórico.

9 O conceito de "civilização" foi interesse de estudo de Norbert Elias, que destacou como seria possível perceber clara distinção entre os desdobramentos do processo civilizador em uma formação sócio-histórica predominantemente franco-britânica, marcada pelo artifício e pela superficialidade das relações sociais e, em outra perspectiva, a kultur alemã, cuja característica principal seria a valorização de um traço interior, particular e profundo. A utilização de palavras como "Kultur", "kultivierte" e "bildender", nos escritos filosóficos de Schiller, aponta para aspectos etimológicos que reforçam a noção de que a compreensão do que seriam a "civilização", o homem "civilizado" e o espírito "civilizador", respectivamente, não pode ser confundida com ideias predominantes na experiência das Luzes francesas como "progresso". Mas ainda assim, o uso e entendimento que Schiller atribuiu a esses termos aproximam seu significado ao que Norbert Elias reconhece como uma "função geral do conceito de civilização", como "consciência que o Ocidente tem de si mesmo" (ELIAS 1994, p. 23). Em carta a Goethe, Schiller afirmara que o amigo era possuidor de um "espírito civilizador"; em alemão, o vocábulo utilizado é "bildender", isto é, o radical da palavra, "Bild"- imagem, ideia, noção -, é o mesmo de "Bildung", cujo significado remete a um processo contínuo e inconcluso de cultivo e formação, seja do indivíduo ou de um povo (GOETHE; SCHILLER 2010, p. 29).
} 
O olhar do poeta alemão sobre o passado que o interessava como constituinte de sua identidade germânica e moderna é peculiar. Desse modo, aproximar-nos do ensaio de Schiller permitiria o contato com uma noção de história na qual tal processo descrito por Reinhart Koselleck (2006) como dissolução do topos da história magistra vitae e surgimento de uma história como singular-coletivo ainda não havia sido concluído. A fim de manter o diálogo com Koselleck, agora remontamos a sua teoria dos tempos históricos para lançar mão da noção de estratificação do tempo, que nos permitiria pensar como elementos da concepção clássica de história se articulam a aspectos prenunciados pelo conceito moderno de história, em uma dinâmica na qual mudança e recorrência conferem ao presente caráter distinto, em uma experiência na qual essas camadas do tempo se sobrepõem e se confundem no processo de sedimentação cultural.

Na formulação schilleriana, o retorno ao referencial antigo não se justificava pela imitação de seus feitos, nem pela superação de sua cultura. A luz que a Grécia clássica lançava sobre a modernidade se impunha como um imperativo ético, um dever ser, um ideal a lembrar ao homem moderno sua verdadeira vocação: "São o que nós fomos; são o que devemos vir a ser de novo. Fomos natureza como eles, e nossa cultura deve nos reconduzir à natureza pelo caminho da razão e da liberdade" (SCHILLER 1991, p. 44).

O passado assim referido abre espaço para uma experiência do tempo histórico que não se encerraria nos paradigmas em disputa, a saber, a história 108 mestra da vida ou a história processual, como um singular-coletivo. Em PIS, é estabelecida uma interessante relação entre passado e futuro, na qual o debate na esteira da "querela entre antigos e modernos" poderia adquirir nova configuração. Se antes os intelectuais nas academias francesas mobilizavam-se entre os defensores dos antigos e os partidários dos modernos, com PIS ficava estabelecida a superioridade da razão moderna, mas o traço genial somente poderia ser produzido por aquele que se aproximasse da primeira natureza, perdida no fluxo da história.

A natureza como um "dever ser" presente em todo o projeto estético de Schiller nos autorizaria a pensar como sua reflexão se insere em uma experiência histórica compartilhada naquele cenário alemão de inícios dos novecentos. 0 passado não nos é por ele apresentado como uma tábua de prescrições, nem mesmo como uma etapa superada, mas como um devir, como um imperativo, em outras palavras, como uma imposição ética. No projeto estético de Schiller, é essa imposição ética que leva à ação: o poeta, o intelectual, o indivíduo devem agir. É importante notar que até mesmo certa legitimação dos tempos modernos emerge dessa concepção da história como um "dever ser", afinal, a modernidade, como todo presente, seria o momento privilegiado para o cumprimento dessa vocação. Apesar de toda a crítica a sua sociedade e ao ataque à perfídia do mundo da política e dos interesses, Schiller ainda acreditava na eficácia de uma educação estética que pudesse contribuir para a transformação do mundo através do cultivo dos sentidos. Se o diagnóstico era desafiador, a expectativa, por sua vez, revelava maior otimismo quanto aos desdobramentos do processo 
histórico no qual ele mesmo estava inserido. Os tempos modernos têm aqui sua importância reafirmada pelo lugar privilegiado para a ação.

A reflexão de nosso poeta pode ser compreendida como uma reação a uma nova consciência do tempo, que emergiu do Iluminismo francês, sobretudo expresso na querela e em seus desdobramentos, mas que ainda não havia sido incorporada à norma linguística até então. Se com Charles Perrault a proeminência da presente face ao passado atribuiu caráter progressivo à consciência do tempo, em PIS o conceito de moderno assumiu o conteúdo não apenas de "novo", bem como de "mudança" e "transição", influenciando grandemente o léxico germânico (GUMBRECHT 1992, p. 89-92).

Se nos propusermos a um exercício analítico análogo ao empreendimento de Hans Ulrich Gumbrecht em "Cascatas de modernidade", poderemos compreender de maneira mais ampliada a importância - e até mesmo o pioneirismo - de PIS na elaboração de sentidos para o processo histórico de transformação epistemológica que caracterizaria a segunda cascata de modernidade. Na primeira experiência de modernização, o surgimento do sujeito cognoscente como um "observador de primeira ordem" configuraria uma valorização do indivíduo como produtor de conhecimento a partir da observação da natureza e do mundo que o cerca; por volta de 1800, esse observador teria vivenciado uma significativa virada epistemológica que o teria transformado em um "observador de segunda ordem", isto é, sujeito do conhecimento que ao mesmo tempo em que observa seu objeto é capaz de se auto-observar como agente da primeira observação. ${ }^{10}$ Esse sujeito autorreflexivo tem como desafios a tarefa de entender como se relacionar com experiências que são exclusivamente baseadas em conceitos, além de ter de lidar com aquilo que posteriormente foi denominado por Michel Foucault como "crise da representabilidade". ${ }^{11}$

Um exemplo instigante dessa experiência partilhada, na qual Schiller tomou lugar, reside em grande parte na obra do pintor Caspar David Friedrich, que nos convida a observar seus personagens observando o mundo, como na célebre tela do romantismo alemão "Viajante sobre um mar de névoa". Caspar David, para quem "pintar era questão de autodisciplina e 'trabalho consciente'", ou seja, um artista indubitavelmente sentimental, a reflexão filosófica nunca foi um ofício, mas ainda assim seus quadros são reveladores dessa virada epistemológica da qual estamos tratando. Suas telas nos impõem o questionamento: o que pensam os outros? Como os demais veem o mundo? Nas imagens criadas pelo pintor alemão, somos convidados a observar diferentes pontos de vista sobre a realidade. Segundo Gumbrecht (2014, p. 83-93), se tornara cada vez mais difícil para a sociedade burguesa ignorar as infinitas possibilidades e perspectivas para os sentidos e percepção da realidade. A busca por uma nova harmonia

\footnotetext{
${ }^{10}$ Embora a utilização da categoria de "observador de segunda ordem" remeta ao trabalho de Niklas Luhman, o uso que fazemos aqui está diretamente associado à apropriação de Gumbrecht (1998) em Modernização dos sentidos.

${ }_{11} \mathrm{Um}$ aspecto central desta crise causou bastante instabilidade no pensamento historicista alemão de inícios do século XIX, uma vez que a legitimação de representações múltiplas sobre o passado, sem a hierarquização de tais imagens, incorreu na crítica do relativismo total e da própria impossibilidade do conhecimento histórico. O observador que é incapaz de deixar de se observar enquanto observa o mundo já não pode assegurar o estabelecimento de uma verdade cuja validade pode ser sustentada universal e perenemente.
} 
seria mais um dos sintomas desse sujeito moderno cindido. Seguindo esta linha analítica, seria possível admitir que, no momento da escrita de PIS, Schiller se encontrava no limiar de uma modernidade em transformação. Vivendo exatamente no período de estabilização do segundo sentido deste processo de modernização, o movimento interpretativo que Schiller propôs acerca de seu tempo pode ter fornecido à tradição ocidental o primeiro esforço filosófico e estético com o objetivo de compreender a virada epistemológica em processo no mundo europeu no período do Sattelzeit. ${ }^{12}$

Em seu ensaio, Schiller utiliza as categorias de ingênuo e sentimental para pensar diferentes formas de o poeta se relacionar com a natureza, mas, ao fim da leitura, estamos convencidos de que há algo para além da preocupação com a produção artística em sua reflexão. De maneira quase intuitiva, Schiller nos diz sobre a condição mesma do intelectual em seu tempo. Assim sendo, não seria o poeta sentimental um observador de segunda ordem? Caso aceitemos esta conclusão como verdadeira, sua condição autorreflexiva seria, concomitantemente, sua maior vantagem e também o motivo de sua melancolia. A poesia sentimental é justamente aquela que não pode ser dissociada da subjetividade daquele que a produziu, e quem, senão o autor desta poesia, para apontar o caráter perspectivado de sua produção? Sem a pretensão de equiparar o poeta ingênuo a um observador de primeira ordem, outrossim consideramos pertinente compreender o poeta sentimental pari passu aos traços característicos do observador de segunda ordem, cuja produção artística seria 110 potencializada e maculada por sua atividade reflexiva.

Ora, se na estética de Hegel a morte da arte estaria condicionada exatamente a esta capacidade do homem moderno dos oitocentos de tornar-se um observador de si mesmo - algo que comprometeria a precondição para uma arte verdadeira, baseada na relação imediata entre a subjetividade do indivíduo e o objeto da fruição estética -, ao analisar o PIS segundo os mesmos termos, chegaríamos a conclusões notadamente diversas. Para Schiller, cujo espírito passional não foi o suficiente para afastá-lo de soluções conciliatórias, seria desejável, e até mesmo realizável no âmago do poeta, a coexistência entre o ingênuo e o sentimental. Todavia, não é este o ponto que nos interessa enfatizar aqui. Voltando à tese hegeliana, certamente Schiller discordaria veementemente de Hegel acerca do postulado do fim da arte, sobretudo porque para Schiller o advento da racionalidade e o caráter autorreflexivo do poeta moderno eram conquistas de um processo histórico no qual o homem se tornara cada vez mais autônomo em relação à natureza, por meio de sua consciência dela e de si próprio. A melancolia decorrente desta ruptura o faz querer retornar ao idílio, mas, impossibilitado de fazê-lo, transforma essa ausência em ideal. A arte, dessa forma, seria alçada ao seu mais alto patamar, no qual a beleza seria fruto não de um processo natural, mas da capacidade humana de pensar e conhecer

12 Reinhart Koselleck (2006) afirmou que, entre 1750 e 1850, mudanças significativas ocorreram nas sociedades europeias. Tais mudanças alteraram de forma profunda o modo de os homens se relacionarem com o tempo e compreenderem a história, de maneira que as transformações poderiam ser verificadas, até mesmo, na intensa reestruturação vocabular e conceitual desse período. 
a si mesma e seu mundo. Schiller não apenas almejava salvar a arte, bem como oferecera a seus contemporâneos uma das imagens da modernidade mais recorrentes na cultura ocidental que se seguiu à recepção de seu ensaio: a ideia do sujeito fraturado.

\section{Algumas considerações}

Schiller compartilhava com grande parte de seus colaboradores intelectuais as concepções de tempo e história que se apresentavam no bojo da difusão do cronótopo historicista, o qual pode ser também caracterizado pela concepção de que os homens "fazem a história". Esta noção - diretamente relacionada ao tempo histórico e sua temporalização, pois quando o futuro está aberto como possibilidade de construção e o sentido da história está depositado nele, os homens se sentem impelidos a construí-lo - pode ter sido a motivação de Schiller ao tornar públicas suas ideias em Poesia Ingênua e Sentimental.

Àquela época, pensar sobre as formas de produzir arte implicava não apenas a constituição de uma estética, mas também de um ideal de humanidade. As disputas em torno do que se convencionou chamar de classicismo e romantismo incitavam questões que ultrapassavam a produção artística, estavam em jogo também as ideias de progresso e civilização que, embora não fossem negadas por nenhum dos dois pontos de vista, seriam alvo de diferentes perspectivas. Então, na mesma medida em que Schiller se preocupava com um debate para além de sua contenda com Goethe, seu ensaio também tomou proporções maiores, influenciando o ambiente cultural alemão e legando à posterioridade uma síntese cultural que até hoje se faz presente na tradição ocidental.

O homem moderno sofria com o seu esfacelamento e buscava novamente sentir-se inteiro, assim como o era no quadro idealizado da humanidade tomado de empréstimo dos antigos. Porém, a simples emulação não resolveria o problema. Dessa vez, o homem deveria conciliar a harmonia com a natureza e sua autonomia de consciência. O poeta sentimental, nos disse Schiller, é aquele que reconhece o homem dilacerado, que busca reunificá-lo, mas que o faz com a plena consciência de estar travando uma batalha perdida. No entanto, essa constatação não significa a derrota da modernidade, pelo contrário, ela atestava sua predestinação, afinal toda poesia a partir de então deveria ser sentimental ou, em outros termos, moderna.

Essa Ideia da natureza como o "dever ser" da humanidade revela o entendimento do processo histórico como uma evolução, tal qual presente nas concepções historiográficas de Herder e Humboldt, que entendiam o conceito de evolução como amadurecimento, como uma transformação gradual e orgânica do elemento que já estava compreendido desde o início do processo. ${ }^{13}$ Se por um lado a natureza é o nosso dever ser, por outro a nossa experiência com a natureza não deve ser a mesma em todo o devir. No mundo antigo, a natureza era imprescritível à experiência humana, na modernidade o laço com a natureza

${ }^{13}$ Aqui nos é deveras cara a interpretação de Hayden White (2008) acerca do uso da metáfora na escrita da história de Herder. 
deve ser atado por intermédio da razão. Esse segundo momento, aos olhos de Schiller, seria superior, pois capaz de conduzir o homem à liberdade. Nesse dever ser, a cultura, razão da separação entre o homem e a natureza, tem o seu papel transformado, pois é através dela e, não de outra forma, que voltaremos à natureza. Por isso, não deveríamos lamentar a perda da naturalidade, ela se deu em nome de uma conquista maior: o primado da razão. A consciência humana produz sentido para o seu mundo, e não o contrário - Schiller concluiu a partir de categorias claramente kantianas. Este imperativo estético assume caráter de um imperativo político no pensamento do poeta alemão, o homem moderno dos escritos de Schiller é o sujeito que deve agir.

\section{Referências bibliográficas}

ARAUJO, Valdei Lopes de. História da historiografia como analítica da historicidade. História da historiografia, n. 12, p. 34-44, 2013.

- Observando a observação: sobre a descoberta do clima histórico e a emergência do cronótopo historicista, c. 1820. In: CARVALHO, José Murilo de. CAMPOS, Adriana Pereira. Perspectivas da cidadania no Brasil Império. Rio de Janeiro: Civilização Brasileira, 2011.

BERLIN, Isaiah. Le Mage du Nord, critique des Lumières. J. G. Hamann 1730-1788. Paris: Presses Universitaires de France, 1997.

CALDAS, Pedro Spinola Pereira. As dimensões do Historicismo : um estudo dos casos alemães. Revista OPSIS, v. 7, n. 9, p. 47-66, 2007.

DEJEAN, Joan. Antigos contra modernos: as guerras culturais e a construção de um fin de siècle. Rio de Janeiro: Civilização Brasileira, 2005.

ELIAS, Norbert. O processo civilizador: uma história dos costumes. Rio de Janeiro: Jorge Zahar Editor, 1994. v. 1.

GOETHE, Johann Wolfgang von; SCHILLER, Johann Christoph Friedrich von. Correspondência. Goethe e Schiller. São Paulo: Hedra, 2010.

GUMBRECHT, Hans Ulrich. Atmosfera, ambiência, Stimmung. Rio de Janeiro: Contraponto: Ed. PUC Rio, 2014.

Making sense in Life and Literature. Minneapolis: University of Minnesota Press, 1992.

Modernização dos sentidos. São Paulo: Ed. 34, 1998.

HERDER, Johann Gottfried. Idées sur la philosophie de I'histoire de I'humanité. Paris: Presses Pocket, 1991.

HUMBOLDT, Wilhelm von. Sobre a Tarefa do Historiador. Anima, ano 1, n. 2, 2001.

KANT, Immanuel. Crítica da faculdade do juízo. Rio de Janeiro: Forense Universitária, 2005. 
KOSELLECK, Reinhart. Crítica e crise: uma contribuição à patogênese do mundo burguês. Rio de Janeiro: EDUERJ; Contraponto, 1999.

. Estratos do tempo: estudos sobre história. Rio de Janeiro: Contraponto; PUC-Rio, 2014.

Futuro Passado: contribuição à semântica dos tempos históricos. Rio de Janeiro: Contraponto; Editora PUC-Rio, 2006.

LÖWY, Michael. SAYRE, Robert. Revolta e melancolia: o romantismo na contramão da modernidade. Petrópolis: Vozes, 1995.

MANN, Thomas. Goethe como representante da era burguesa. In: 0 escritor e sua missão. Rio de Janeiro: Jorge Zahar, 2012.

Os Famintos e outras histórias. Rio de Janeiro: Nova Fronteira, 2000.

OERGEL, Maike. Culture and identity: historicity in German literature and thought (1770-1815). Berlin: W de Gruyter GmbH \& Co, 2006.

PANOFSKY, Erwin. Idea: a evolução do conceito de belo. São Paulo: Martins Fontes, 1994.

PIKULIK, Lothar. Sentimiento de la naturaleza y desnaturalización del sentimiento. Sobre el concepto schilleriano de lo sentimental. In: JIRKU, Brigitte E.; RODRÍGUEZ, Julio (Ed.). El pensamiento filosófico de Friedrich Schiller. València: Univesitat de València, 2009.

RODRIGUES, Antonio Edmilson Martins; FALCON, Francisco José Calazans.

Tempos Modernos: ensaios de história cultural. Rio de Janeiro: Civilização Brasileira, 2000.

SCHLEGEL. Friedrich. Sobre el estúdio de la poesia griega. Madri: Ediciones Akal, 1995.

SCHILLER, Johann Christoph Friedrich von. A educação estética do homem. São Paulo: Iluminuras, 2002.

. Poesia Ingênua e Sentimental. São Paulo: Iluminuras, 1991.

SHARPE, Lesley. Schiller's Aesthetic Essays: two centuries of criticism. Columbia: Camden House, 1995.

SUZUKI, Márcio. Apresentação. In: SCHILLER, Johann Christoph Friedrich von. Poesia Ingênua e Sentimental. São Paulo: Iluminuras, 1991.

SZONDI, Peter. Poésie et Poétique de I'Idéalisme Allemand. Gallimard, 1991.

Weber. Max. A Ética Protestante e o "Espírito" do Capitalismo. São Paulo: Companhia das Letras, 2004.

WHITE, Hayden. Meta-história: a imaginação histórica do século XIX. São Paulo: Edusp, 2008. 


\title{
La convergencia de la historia y el psicoanálisis en Paul Ricoeur
}

\section{Paul Ricoeur's convergence of history and psychoanalysis}

\author{
Esteban Lythgoe \\ estebanlythgoe@yahoo.com.ar \\ Professor titular \\ Universidad Argentina de la Empresa (UADE) \\ San Lorenzo 947 \\ 1640 - Acassuso - Buenos Aires \\ Argentina
}

\section{Resumen}

El tratamiento del psicoanálisis y la historia ha estado presente a lo largo de toda la obra de Ricoeur. Sin embargo, ambas temáticas han sido desarrolladas durante largo tiempo por caminos paralelos. En la década de los ochenta se observan acercamientos desde su interpretación del psicoanálisis hacia la historia. Por su parte, la historia adquiere un giro psicoanalítico en La memoria, la historia, el olvido. Nuestra hipótesis es que Ricoeur debió modificar su concepción de historia y de psicoanálisis para lograr este proceso de convergencia. Para decirlo brevemente, el psicoanálisis se tuvo que 'historizar', y la historia que 'patologizar'.

\section{Palabras clave}

114

Memoria colectiva; Narrativas; Paul Ricoeur.

\section{Abstract}

Ricoeur have been interested in psychoanalysis and history throughout nearly all his work. However, both issues have been developed for a long time on parallel tracks. In the eighties approaches his interpretation of psychoanalysis get closer to history. On the other side, history has its psychoanalytic turn in Memory, History, Forgetting. Our hypothesis is that Ricoeur had to modify his conception of history and psychoanalysis to achieve this convergence process. In short, psychoanalysis had to be 'historicized', and history 'pathologiezed'.

\section{Keywords}

Collective memory; Narratives; Paul Ricoeur.

Recibido el: 11/10/2016

Aceptado el: 4/2/2017 


\section{Dos historias paralelas}

El interés por articular la historia y el psicoanálisis se puede retrotraer hasta la propia obra de Freud. En libros como Totem y Tabú o Moisés y la religión monoteísta, el creador del psicoanálisis propone construcciones genéticas a fin de explicar el origen de ciertas estructuras psicoculturales. Con posterioridad, la Escuela de Frankfurt y Wilhelm Reich articularon desde sus respectivas posiciones la teoría freudiana y la historia, tomando como base al marxismo. Incluso, el propio Lacan, desde finales de la década del cincuenta se interesó por la problemática de la historia, aún cuando sus vínculos con el estructuralismo nos podrían llevar a suponer lo contrario. ${ }^{1}$ A partir de la década de los noventa, los estudios de historia oral y de la memoria, especialmente aquellos focalizados en los efectos traumáticos que tuvieron los campos de concentración y el exterminio durante el régimen Nacional Socialista en las memorias de los individuos y de las colectividades masacradas, renovó el interés por esta articulación disciplinar. Varias han sido las estrategias, así como sus resultados. Los proyectos más reconocidos han sido, entre otros, los de Laub, Felman, Caruth o LaCapra. ${ }^{2}$ Paul Ricoeur también ha desarrollado su propia propuesta de articulación en el marco de su análisis acerca de la relación entre memoria e historia.

Para todo aquel que se haya acercado a la obra de este filósofo a partir de Tiempo y Narración, esta afirmación puede resultar sorprendente, teniendo en cuenta que en esta obra las referencias a Freud no llegan a diez, y casi todas ellas están vinculadas con el tratamiento de la identidad personal. Aunque desde el inicio de su carrera Ricoeur ha estado interesado en cuestiones ligadas al psicoanálisis y a la historia, como lo muestra a lo largo de casi toda su obra, desde Lo voluntario y lo involuntario e Historia y verdad, a mediados del siglo veinte, hasta La memoria, la historia, el olvido del dos mil, ambas temáticas fueron desarrolladas de manera paralela. Deberemos aguardar hasta La memoria, la historia, el olvido en el año dos mil, para que ambos temas lleguen a cruzarse gracias a la aparición de la memoria colectiva. Frente a una memoria colectiva impedida y traumatizada, se sugiere la posibilidad de que la historia tenga como objetivo hacer que se vuelva feliz, es decir, capaz, por medio de un acercamiento de corte psicoanalítico. En el presente artículo quisiéramos sostener que para que este cruce fuera posible en la hermenéutica ricoeuriana se precisaron al menos dos pasos diferentes. En primer lugar, hizo falta 'historizar' al psicoanálisis y 'patologizar' a la historia. En segundo lugar, se tuvo que tratar al psicoanálisis y a la historia bajo la misma figura de la alteridad, la de la carne.

La presente exposición partirá caracterizando en qué consiste el historizar el psicoanálisis en el marco de la hermenéutica de Ricoeur. Para hacerlo, pondremos de manifiesto la modificación conceptual que se produjo (desde) sus primeros tratamientos del psicoanálisis (entre) Lo voluntario y lo involuntario y sus artículos sobre epistemología del psicoanálisis de la década del ochenta. Nuestra intención es poner de manifiesto que en estos últimos artículos Ricoeur presenta

\footnotetext{
${ }^{1}$ No es nuestro interés adentrarnos en esta temática pero como muestra de este interés basta remitirnos a sus consideraciones al respecto en sus seminarios 5 y 7 (LACAN, 1999; 1988).

2 Entre otras obras, cf. LaCapra (2001), Felman y Laub (1992) y Caruth (1996).
} 
una concepción hermenéutica del psicoanálisis, que la acerca ostensivamente al tratamiento narrativo de la historia que hace el filósofo en Tiempo y narración y que, por eso mismo, fue bastante discutida, si no rechazada, por el psicoanálisis. Cerraremos esta parte señalando el modo en que Ricoeur desplaza su interés del problema del super yo al del inconsciente. Si, entonces, por la década del ochenta no se establece un cruce con el psicoanálisis fue porque la historia carecía aún de puntos de contacto con el psicoanálisis. En la segunda parte señalaremos, pues, de qué manera la introducción de la memoria traumatizada en el año dos mil termina por cerrar el nexo entre ambas disciplinas, no sólo patologizando a la historia, sino también reuniendo a la historia y el psicoanálisis bajo la figura de la carne.

\section{Hacia una hermenéutica del psicoanálisis}

Ya de joven Ricoeur se había interesado por el psicoanálisis, gracias a las enseñanzas de su maestro del Liceo de Rennes, Roland Dalbiez, quien, pese a rechazar la doctrina freudiana, reconocía la excelencia de su método. ${ }^{3}$ Sus primeras consideraciones en torno a las teorías freudianas fueron en el marco de su fenomenología de la voluntad, en la primera mitad de la década del cincuenta. A continuación quisiera señalar simplemente tres cuestiones de las cuestiones allí tratadas a fin de establecerlas como puntos de comparación de cómo será el desarrollo de su vínculo con el psicoanálisis. Ellas serán la apreciación de la labor del psicoanálisis, del concepto freudiano de inconsciente, y finalmente, del proceso de cura.

En aquel entonces Ricoeur identificaba el proceder de los analistas con el de los 'demás científicos positivos', ya que, como ellos, buscaban caracterizar el funcionamiento de la psique desde una perspectiva determinista y causal, que dejara de lado la libertad. "Como ha sido dicho desde el comienzo, el método psicoanalítico es inseparable de una física mental donde las imágenes, las representaciones aberrantes son tratadas no como intenciones, de las cuales la absurdidad es ella misma un contenido intencional, sino como 'hechos', 'cosas' a explicar 'causalmente'" (RICOEUR 1950, p. 371). Como veremos, esta posición es muy alejada de la que sostendrá en la década de los ochenta debido a que, en el medio del debate que toma lugar en aquel momento, entre explicacionistas y comprensivistas, Ricoeur sostendrá que el psicoanálisis incluye en su seno algunos componentes explicativos y otros asociados con la comprensión.

La problemática del inconsciente, por su parte, constituía un gran escollo para Ricoeur, tan identificado por aquel entonces con la fenomenología. Influido por esta filosofía de la conciencia, el filósofo calificaba de 'mitológica' la posibilidad de concebir al inconsciente como polo de acción, tal como lo hacía Freud. En su opinión, resultaba absurdo sostener que "[...] el inconsciente no piensa, no

\footnotetext{
${ }^{3}$ Cabe señalar aquí que, en la década de los ochenta, Ricoeur seguirá este lineamiento de Dalbiez, desplazando su interés de la teoría psicoanalítica a la práctica analítica. Es así que nos encontramos con la siguiente afirmación: "si hablo de insatisfacción teórica, es porque cada vez estoy más convencido de que la teoría freudiana es discordante respecto a su propio descubrimiento y que hay más en el descubrimiento freudiano que en el discurso que sostiene" (RICOEUR 2008, p. 279).
} 
percibe, no recuerda, no juzga. Y, sin embargo, 'algo' es inconsciente, que es vecino de la percepción, vecino del recuerdo, vecino del juicio, y que el análisis del sueño y de las neurosis revela" (RICOEUR 1950, p. 364). Antes que recurrir a un concepto de inconsciente que conducía a inconsistencias fenomenológicas que se desprendían de dicho concepto, el filósofo se inclinaba por una acepción más bergsoniana del inconsciente, es decir, como una conciencia latente o irreflexa (RICOEUR 1950, p. 366). Según Dosse, Ricoeur logró superar esta tensión entre fenomenología y psicoanálisis gracias a un artículo de Antoine Vergote de 1958, en el que se ponía de manifiesto la mutua complementariedad entre filosofía y psicoanálisis y se sostenía que Brentano había inspirado tanto a la obra de Freud como a la de Husserl. En la medida en que "Freud descubrió que el psiquismo se define por el sentido, y que este sentido es dinámico e histórico" (DOSSE 2008, p. 290), Vergote sostenía que las investigaciones de Freud eran fenomenológicas.

La concepción causalista del psicoanálisis y la defensa de un concepto de inconsciente como 'conciencia latente' llevaron a que Ricoeur diera una caracterización bastante particular acerca de cuál era el objetivo del psicoanalista. En su opinión, éste era el mismo que el del médico, es decir, la cura, pero concebida como 'volver consciente lo inconsciente'. Este último punto es explicado del siguiente modo,

[...] el factor decisivo de la cura es la reintegración del recuerdo en el campo de la consciencia. Ahí está el corazón del psicoanálisis. Lejos, pues, que el psicoanálisis sea una negación de la consciencia, ella es al contrario, un medio de extender el campo de la consciencia de una voluntad posible por disolución de las contracturas afectivas. Cura por una victoria de la memoria sobre el inconsciente (RICOEUR 1950, p. 360-361).

Busacchi señala que el pasaje que se produjo en la obra del Ricoeur de la hermenéutica del símbolo a la del texto y la narración durante las décadas de los setenta y ochenta, llevó a que se distanciara de la teoría psicoanalítica y se inclinara hacia la 'experiencia' analítica, ${ }^{4}$ lo que supuso destacar aspectos analíticos más afines a temáticas narrativas en detrimento de la cuestión energética. En artículos de aquel período, nos encontramos con manifestaciones explícitas de insatisfacción respecto de la metapsicología (RICOEUR 2008, p. 277-290), e intentos de plantear acercamientos más narrativos a las patologías y curas psicológicas (RICOEUR 2008, p. 139-166). Ricoeur también rechaza a aquellas corrientes postfreudianas que redujeron la problemática psíquica a una economía pulsional. En ese sentido coincide en:

[...] el intento general de [Lacan de] romper como el biologicismo y el behaviorismo atribuidos a los psicoanalistas postfreudianos y de hacer la 'vuelta a Freud' situando en el sólo 'campo de la palabra y del lenguaje' no sólo la situación analítica, sino las operaciones del inconsciente de la cual la teoría emprende la tarea de rendir cuenta sistemáticamente (RICOEUR 2008, p. 120).

\footnotetext{
${ }^{4}$ Cf. Las consideraciones de Busacchi al respecto en postfacio a Ricoeur (2008, p. 307-308).
} 
Quisiera detenerme aquí en los artículos de la década de los ochenta mencionados al comienzo de este artículo, donde se observa este proceso de narrativización señalado y el modo en que Ricoeur se enfrentó a la problemática de articular aquellos componentes del psicoanálisis más afines con las explicaciones causalistas con aquellos otros más narrativistas. A fin de mostrar la distancia de la interpretación de Ricoeur respecto de Freud y de la tradición psicoanalítica, incluiré, junto con la propuesta del filósofo francés, algunas de las críticas que le realizaron diversos psicoanalistas.

Para Ricoeur, el psicoanálisis descansa sobre dos pilares 'científicos': la determinación del hecho analítico y el tipo de relación entre la teoría y la experiencia analítica. ${ }^{5}$ Los hechos analíticos se distinguen de los demás hechos científicos en cuatro aspectos (RICOEUR 2008, p. 281; 1986, p. 1). En primer lugar, el único deseo que se encuentra en condiciones de ser evaluado es el que puede ser dicho. Ricoeur sostiene que una experiencia pulsional es susceptible de ser dicha y, por lo tanto, pasible de ser descifrada, traducida e interpretada. Con otras palabras, el pathos humano tiene una profunda afinidad con el logos humano, y es eso justamente lo que lo vuelve humano. En su opinión, "podríamos decir que el psicoanálisis extiende el lenguaje más allá del plano lógico hacia las regiones alógicas de la vida, que hace hablar esta parte de nosotros mismos que no es muda sino porque ha sido constreñida al silencio." (RICOEUR 2008, p. 108). Para apoyar su posición, Ricoeur se apoya en los resultados de las investigaciones de Mitscherlich, según las cuales la enfermedad, la psicosis

118 y la neurosis consisten en una descomposición de la función simbólica. Dada la naturaleza simbólica de la enfermedad, la tarea del analista consistiría en 'reintroducir al paciente en la comunidad lingüística' (RICOEUR 2008, p. 281). Este primer aspecto se enfrenta de lleno a la posición de analistas como Sédat, para quién "no hay experiencia pulsional susceptible de ser dicha. La única cosa que puede ser dicha es una experiencia representativa. No hay un pulsional puro que pueda ser dicho. La única cosa que puede ser dicha depende del registro de una actividad de representación" (RICOEUR 2008, p. 100).

El segundo atributo que caracteriza al hecho analítico es el carácter intersubjetivo y, consecuentemente, dialógico del deseo. La mediación del otro es constitutiva del deseo, en tanto que es dirigido a otro, real o fantasmal, presente o ausente, que a su vez puede responder a dicho deseo o rechazarlo. Como diría Hegel, "el deseo es deseo del otro." Justamente este atributo hace posible el proceso de transferencia que rompe con la compulsión del paciente y transforma la repetición en un proceso de rememoración. Por este motivo es que, frente al modelo monológico de la libido, presentado por Freud y algunos seguidores ${ }^{6}$ Ricoeur insiste en su carácter intersubjetivo.

\footnotetext{
${ }^{5}$ Demás está señalar que el carácter científico del psicoanálisis es rechazado desde algunos sectores del psicoanálisis, incluyendo al Lacan maduro. Jacques Sédat, psicoanalista incluido por Dosse en su compilación sobre la relación entre Ricoeur y las ciencias humanas, reconoce su distancia sobre este punto. Así explica que, "me parece importante destacar que, desde el punto de vista de un psicoanalista, las cuestiones no se plantean como lo intenta hacerlo Ricoeur, porque el psicoanálisis no tiene un estatus epistemológico, no es una ciencia. Ella tampoco es un discurso organizado, sistematizado como el discurso filosófico" (SÉDAT 2007, p. 99). ${ }^{6}$ Cf. Ricoeur (2008, p. 281): "El modelo psicoanalítico me ha llamado la atención como siendo un modelo monológico." Cf. tb. J. Sédat (2007, p. 100): "[...] la relación analítica no es una estructura dialógica, sino proyectiva".
} 
El tercer aspecto que caracteriza a un hecho analítico su carácter imaginario. Aunque no tan difundida como su interés por la narración, la imaginación es una de las temáticas que caracteriza a la hermenéutica de Ricoeur respecto de, por ejemplo, la de Gadamer y que lo distancia de Husserl. A diferencia de la tradición fenomenológica, cuyo tratamiento de la imaginación que lo identifica con la sensibilidad y la concibe como reproductiva, la imaginación ricoeuriana es productiva y eminentemente lingüística (KEARNEY 1998, p. 134). Esta perspectiva lleva a que el interés de Ricoeur no se centre en los contenidos imaginarios, sino por sus funciones que son la proyección intencional de sentidos posibles y la síntesis esquemática de lo múltiple (KEARNEY 1998, p. 140). Dentro de este marco conceptual debe ser comprendido el modo en que es destacado y desarrollado este tercer atributo. Su punto de partida es la observación de Lacan acerca de lo que considera ser una ilusión fundamental: uno cree dirigirse al Otro, pero alcanza a otro que el Otro (el objeto a). Esta afirmación encierra la doble cara del imaginario, por una parte, se encuentra el componente fantasmático, ilusorio, engañador, y por el otro, su elemento creativo. "La oposición que hace Lacan entre lo imaginario y lo simbólico me resulta muy útil: en este contexto, lo imaginario es considerado como engañador, y lo simbólico nos lleva al orden mismo constitutivo del orden humano: el orden fundamental del lenguaje" (RICOEUR 2008, p. 283). Según el filósofo francés, el componente falsificador es el asociado a lo patológico de la función simbólica, y que Habermas abordará junto con la crítica a las ideologías en Conocimiento e interés.

En el cuarto atributo del hecho analítico hace finalmente su aparición el elemento narrativo. Consecuente con la relación entre narratividad y temporalidad que el filósofo había desarrollado por aquella época en Tiempo y narración, este aspecto incorpora la dimensión temporal, fundamental en la constitución de la enfermedad y para su tratamiento. Este componente temporal constituye al psicoanálisis en una arqueología del deseo. Asociado al tiempo se encuentra la caracterización narrativa del componente mnémico. Años más tarde, esta incorporación lo llevará a caracterizar al trauma, la repetición y la resistencia no sólo como la imposibilidad de integrar algún acontecimiento a un contexto significativo, sino también como la disociación del pasado respecto de los otros tiempos. ${ }^{7}$ Por lo tanto, la cura mnémica será también un proceso de integración narrativo/temporal. ${ }^{8}$

Es preciso, empero, señalar que la afirmación de Busacchi de la tendencia de Ricoeur a narrativizar el psicoanálisis tiene un límite, ya que, aún en las décadas del setenta y ochenta, Ricoeur reconoce que su afinidad con Freud, se debe a que el creador del psicoanálisis reivindica una doble epistemológica, dividida en una energética y una hermenéutica. De hecho, por aquellas épocas es su rechazo a la

\footnotetext{
7 Cf. Ricoeur (1995b, p. 78): "La cuestión es, en efecto, de saber si no es la relación pasado-presente-futura en su totalidad, que sufre heridas y traumatismos y que demanda ser curada."

${ }^{8}$ En su artículo sobre la capacidad del perdón de curar, se plantea el rol del perdón en los siguientes términos temporales: "[...] el perdón acompaña el olvido activo, aquel que hemos vinculado al trabajo de duelo; y es en este sentido que cura. Pues no alcanza a los acontecimientos cuya huella debe ser protegida, sino sobre la deuda cuya carga paraliza la memoria y, por extensión, la capacidad de proyectarse de manera creadora en el futuro. Y es toda la dialéctica del pasado y del futuro la que es puesta en movimiento, el proyecto que surge en el recurso inmenso de las promesas no cumplidas en el pasado" (RICOEUR 1995b, p. 81).
} 
idea de que la tesis lacaniana de la identificación de lo simbólico con lo lingüístico constituya una superación de las limitaciones de la explicación económica. En opinión de Ricoeur, la reducción de la totalidad de las estructuras psíquicas al lenguaje ${ }^{9}$ duplica la explicación económico-pulsional a nivel lingüístico:

Pero la interpretación lingüística no constituye una alternativa de la explicación económica; sólo sustrae esta última a la reificación, haciendo ver que los mecanismos correspondientes a la económica sólo nos son accesibles en su relación con la hermenéutica. Afirmar que la represión es una 'metáfora' no es sustituir la hipótesis económica, sino duplicarla con una interpretación lingüística, y así incorporarla al universo del sentido sin reducirla a él (RICOEUR 1970, p. 346).

La doble epistemología de Freud se pone de manifiesto en el modo en que articula la teoría con los hechos a través del procedimiento, el método y la colección de concepciones psicológicas. El procedimiento se interesa por las relaciones de significación entre las producciones mentales, el método de tratamiento refiere a las relaciones de fuerza entre los sistemas y la teoría integra los dos aspectos anteriores. ${ }^{10}$ La producción, en tanto se interesa por las relaciones de significación, tiene una profunda afinidad con las disciplinas de interpretación textual. Ricoeur defiende la pertinencia de su acercamiento hermenéutico al psicoanálisis remitiéndose a La interpretación de los sueños, donde Freud habría señalado que su objetivo sería poner de manifiesto la susceptibilidad de los sueños a ser interpretados, es decir, que se les podría asignar una significación. La homogeneidad entre la formación del sueño y la del síntoma permitiría considerar a la psique como un texto a descifrar. Laplanche ha objetado fuertemente el acercamiento entre el psicoanálisis y la hermenéutica, enfatizando que Freud no utiliza la expresión Auslegung sino Deutung. A la hora de explicar en qué consiste la labor de la Deutung, Laplanche lo hace asociándolo al término Aufdeuten, que significa indicar, separar. Así, el objetivo de "La interpretación de los sueños" y "Estudios sobre la histeria" consistiría en presentar asociaciones y desciframientos, no interpretaciones estereotipadas. A tal punto es así, que "el capítulo [del sueño de Irma] termina en forma abrupta y hasta decepcionante." (LAPLANCHE 1996, p. 3). El método analítico, entonces, no se puede caracterizar ni como traducción ni comprensión ni lectura, sino que es una destraducción.

Habíamos señalado más arriba que la contracara del componente 'hermenéutico' del psicoanálisis radica en la cuestión clínica y el uso de metáforas cuasi físicas para explicarlas (RICOEUR 1986, p. 7). A los ojos de Ricoeur el uso de un lenguaje causalista y modelos tópicos-económicos para complementar otra serie de categorías ligadas con un modelo hermenéutico,

\footnotetext{
${ }_{9}^{9}$ Cf. Ricoeur (2008, p. 105; 1970, p. 320 y 345): "[...] que la experiencia psicoanalítica se desenvuelve en el campo de la palabra y que, dentro de este campo, lo que se ilumina es otro lenguaje, disociado del lenguaje común y descifrable a través de sus efectos de sentido: síntomas, sueños, diversas formaciones, etc.".

${ }_{10}$ Cf. Ricoeur (1986, p. 6). De hecho en la página 8 señala el problema de la inverificabilidad de la psique, y el hecho de que se tiene que probar en bloque los tres elementos. Operativamente los términos teóricos deben ser religados a los observacionales a través de reglas de interpretación o traducción, que aseguran la verificación indirecta de los términos. La cuestión a saber es si los procedimientos operativos que aseguran la transición tienen la misma significación en psicoanálisis que en las ciencias observacionales.
} 
pone de manifiesto la irreductibilidad de ambos modelos. El método estaría vinculado con este aspecto clínico.

La dificultad de articular estos dos componentes conceptualmente tan diferentes es superada por el tercero ellos, que articula el componente teórico con los hechos. Frente a quienes objetan el carácter autoconfirmatorio del psicoanálisis, el filósofo sostiene una circularidad virtuosa. Según explica,

[...] un círculo es vicioso si la verificación en cada uno de los dominios considerados es la condición de verificación en el otro dominio. El círculo de la verificación no será vicioso si la validación procede de manera acumulativa, por el refuerzo mutuo de los criterios que, tomados aisladamente, no serían decisivos, pero cuya convergencia los vuelve plausibles $y$, en el mejor de los casos, probables e incluso, convincentes (RICOEUR 1986, p. 8).

Los criterios convergentes sobre una buena explicación serían cuatro, que simplemente mencionaremos, para traerlos a colación en el siguiente apartado: a. ser coherente con la teoría o conformarse con el sistema psicoanalítico; b. satisfacer las reglas universalizables de la decodificación del texto inconsciente; c. ser satisfactorio en términos económicos, es decir, el analizante debe mejorar terapéuticamente; d. elevar una historia particular de caso a la inteligibilidad narrativa que se espera ordinariamente de un relato.

El último paso para acercar el psicoanálisis a la historia se produce en el marco la dialéctica especulativa ipseidad - alteridad. Ricoeur cierra su análisis de la identidad personal en Sí mismo como otro, rechazando la tesis de que el sujeto es una instancia activa que cumple la función de fundamento, a través de un análisis de la alteridad. En dicho análisis, se describen múltiples experiencias de la pasividad, que ponen de manifiesto que el otro no es aun agregado de la ipseidad, sino que es parte constitutiva de la identidad del sujeto. Ricoeur distingue tres tipos de experiencias de la pasividad en las que el sí se encuentra la alteridad: el otro como carne, como otro y como conciencia. La primera de las experiencias remite a un principio de acción interno a nosotros pero que no podemos dominar sino que padecemos. La tradición fenomenológica asocia este concepto al cuerpo propio, que no es un objeto, pero tampoco podemos identificarlo absolutamente conmigo. Richard Kearney destaca la importancia de esta modalidad como modo de articular el sí con el otro: la carne "...es el polo de referencia de todos los cuerpos que pertenecen a esta naturaleza inmanente de lo propio. Y es emparejando nuestra carne con otra que derivamos la noción de un alter-ego. Pero aquí volvemos a la paradoja más profunda: la carne es un paradigma de lo otro. La carne es lo que es más mío y más extraño. Más cerca de mí y más alejado de mí al mismo tiempo" (KEARNEY 2015, p. 184). El otro en tanto la alteridad, apunta a aquello que es distinto de nosotros pero que nos afecta. Un ejemplo de esta experiencia se da en el diálogo donde se observa la interrelación entre locutor e interlocutor, donde cada locutor es afectado por la palabra que se le dirige. Ricoeur menciona también el caso de la narración "el mismo intercambio entre el sí afectado y lo otro que afecta es el que rige, en el 
plano narrativo, la asunción por el lector del relato, de funciones desempeñadas por personajes construidos casi siempre en tercera persona, en la medida en que son puestos en forma de trama al mismo tiempo que la acción narrada" (RICOEUR 1996, p. 366). La última figura de la alteridad, está asociada con el plano moral, y ubica a la alteridad, a la vez, dentro y por encima de nosotros, conminándonos a actuar de cierto modo.

En Sí mismo como otro, Ricoeur el psicoanálisis es tratado dentro de la tercera de las figuras de la alteridad dado que el eje interés era la problemática del super yo, tal como es tratada en "El yo y el ello" (RICOEUR 1996, p. 395). A partir de su artículo "Múltiple extrañeza", cuatro años más tarde, Ricoeur va a modificar su tratamiento del psicoanálisis (BUSACCHI 2010, p. 442). En lugar de centrarse en cuestiones ligadas al superyó, el filósofo se inclinará por la pulsión y la compulsión, tal como son tratados en "Lo ominoso" y "Rememoración, repetición, per-laboración" (RICOEUR 2013, 402-3). De este modo, dejará de ubicar al psicoanálisis dentro de la experiencia de la alteridad en tanto conciencia, para abordarla desde la experiencia de la carne.

En síntesis, la concepción de Ricoeur acerca del psicoanálisis fue modificándose en los casi cincuenta años de estudiarla, volviéndola más afín a una concepción narrativa de la historia. En sus años de juventud, Ricoeur destacaba los componentes explicativos y causalistas del psicoanálisis, y se consideraba en una posición antitética. Asimismo, sus vínculos con la fenomenología lo llevaron a desconfiar del inconsciente como polo de acción. Dentro de este

122 marco, la cura era definida como volver consciente lo inconsciente. Durante los años setenta y ochenta, el acercamiento de Ricoeur a la hermenéutica de la narración, lo condujo a concebir al psicoanálisis en términos narrativos, aún manteniendo una contraparte explicativa, asociada con la economía pulsional. La cura analítica es caracterizada como la integración narrativa/temporal del acontecimiento traumático. También se observan desplazamientos en los temas de interés por parte de Ricoeur, que inciden en el tipo de abordaje que se hará de dicha disciplina. A los efectos de nuestra investigación, resulta especialmente relevante el pasaje del interés por el super yo a comienzo de la década del noventa, a preocuparse por las pulsiones. Junto con este cambio, también se modifica el tipo de experiencia de la alteridad con el que estará asociada esta disciplina, dejando de ser la alteridad en tanto conciencia para vincularse con la alteridad en tanto carne.

\section{'Patologizar' la historia}

Hasta aquí hemos relevado el primero de los aspectos del proceso de convergencia entre el psicoanálisis y la historia, a saber: la historización del psicoanálisis. Como hemos visto, en la obra de Ricoeur este proceso de historización fue posible gracias a su narrativización. Si esta historización del psicoanálisis no concluyó en la articulación definitiva con la historia en la década de los ochenta, ello se debió entre otros motivos, a que en aquel entonces el acercamiento ricoeuriano de la historia aún carecía de los elementos conceptuales necesarios para acercarla al psicoanálisis. Para decirlo rápida y crudamente, 
faltaba 'patologizar' a la historia. En el caso de Ricoeur, esta 'patologización' se produce con la incorporación de la memoria y sus patologías en el ámbito de interés de la historia, en las secciones dedicadas a la fenomenología de la memoria y del olvido en La memoria, la historia, el olvido en el año dos mil. A continuación presentaremos brevemente dicha incorporación. En contraposición a la necesidad de una epistemología mixta a la base del psicoanálisis defendida en el apartado anterior, en el año dos mil, el carácter colectivo de la memoria, Ilevará a que Ricoeur se distancie de todo tratamiento 'fisicalista', enfrentándolo, pese a su necesidad a la hora de explicar las patologías mnémicas.

La primera parte de La memoria, la historia, el olvido está dedicada a una fenomenología de la memoria. Tradicionalmente la memoria fue definida como el registro pasivo y debilitado de una experiencia previa. En ese sentido, resulta icónica la comparación platónica de la memoria con el sello de cera, que con el trascurso del tiempo se va desvaneciendo. Esta metáfora pretende explicar dos aspectos diferentes: el primero consiste en la adecuación de la marca con aquello que la causó en el pasado, y la segunda el mantenimiento de la marca a lo largo del tiempo. Dado que Ricoeur rechaza la posibilidad de establecer un vínculo de adecuación entre la marca y lo que lo causa, el filósofo plantea un concepto diferente de memoria que enfatiza el mantenimiento de la huella a lo largo del tiempo. ${ }^{11}$ Ricoeur, por el contrario, concibe a la memoria como una actividad, cuyo punto definitorio es el momento bergsoniano del reconocimiento. Justamente por ello se incluyen dentro de las capacidades que definen al ser humano. ${ }^{12}$ Esto significa que la memoria recuerdo es el producto de una configuración sintética, es decir, narrativa, entre lo que denomina "recuerdo puro", que es lo que se ha mantenido de la afección pasada y una imagen construida por la imaginación. Cuando tras esta síntesis reconocemos el recuerdo, decimos que la síntesis ha sido exitosa. Esta caracterización de la memoria, vuelve inaplicable la noción de una verdad como adecuación al pasado, ya que su componente imaginativo la vuelve inviable. ${ }^{13} \mathrm{~A}$ su vez, esta concepción de la memoria supone la constante reelaboración de las estructuraciones anteriores sin que ello signifique que dichos recuerdos sean falsos. En síntesis, recordar no significa reproducir lo vivido, sino "[...] ser capaz de constituir su propia existencia en forma de historia, de tal modo que un recuerdo aislado no sea sino el fragmento de un relato. Es la estructura narrativa de estas historias vividas la que hacen de una vida una 'historia de caso'"' (RICOEUR 1986, p. 4). ${ }^{14}$

\footnotetext{
${ }_{11}$ Sobre la crítica a la adecuación entre el recuerdo y lo que lo causa, cf. Lythgoe $(2015$, p. 36).

12 Cf. Ricoeur (2004, p. 145): "En primer lugar, se inscriben, de modo original, en las capacidades del hombre capaz: se habla, en efecto, de poder acordarse y de poder prometer como de los otros poderes [...]".

${ }^{13}$ De ahí que el filósofo, tras haber argumentado contra la pertinencia de la verdad mnémica, sostenga que la memoria debe aspirar a la verdad con las siguientes palabras: "Entonces sentimos y sabemos que algo sucedió, que algo tuvo lugar, que nos implicó como agentes, como pacientes, como testigos. Llamemos fidelidad a esta exigencia de verdad" (RICOEUR 2008, p. 79).

${ }_{14}$ Freud tiene su propia metáfora de la memoria en la figura de la "pizarra mágica", esto es, una lámina de cera oscura sobre la cual se coloca una capa trasparente, consistente de una lámina de celuloide y un papel encerado separables entre sí. Con un punzón se escribe sobre el celuloide, lo que hace que el papel encerado se oprima contra la cera y se pueda leer lo escrito. Cuando se separa el papel encerado de la capa oscura, desaparece lo escrito, aunque en la lámina de celuloide termine quedando todo lo que alguna vez se ha escrito. Según Freud, "[...] no nos parece muy aventurado comparar la cubierta compuesta por el celuloide y el papel encerado con el sistema receptor de los estímulos y su dispositivo protector; la lámina de cera, con el sistema
} 
Una vez presentada esta novedosa concepción de la memoria, el segundo paso argumentativo de Ricoeur consiste en disociar a la memoria de la subjetividad. Para lograrlo no pondrá de manifiesto el error de lo que Ricoeur denomina la 'tradición de la mirada interior', a la que el propio Ricoeur está vinculado a través de su vínculo con la fenomenología husserliana. En su lugar, desarrollará dos líneas alternativas, una ligada con la memoria y la otra con el olvido. En la primera de ellas, profundiza su fenomenología de la memoria arriba, proponiendo una definición hermenéutica de la memoria no ligada a la facultad psicofisiológica del ser humano, sino que, en su lugar, priorice la función narrativa de recolección y preservación de los acontecimientos pasados a través del lenguaje público. ${ }^{15}$ Esta redefinición, apoyada sobre los planteos de Strawson sobre la atribución múltiple, proporcionaría un marco lingüístico compartido para el diálogo entre la tradición de la mirada interior y la sociológica. Según la tesis desarrollada en Los individuos, para encuadrarse dentro de este ámbito lingüístico los predicados deben cumplir las siguientes condiciones: 1. la atribución debe poder ser suspendida u operada, 2 . los predicados deben guardar el mismo sentido en dos situaciones de atribución diferentes, 3. esta atribución múltiple debe mantener la disimetría entre adscripción a sí mismo y adscripción al otro. La manera en que es desarrollada la fenomenología de la memoria es una muestra del cumplimiento de la primera condición, pues en ella se desimplica al qué y al cómo de la memoria de quién recuerda. La segunda condición se logra gracias a la suspensión de la atribución, que permite adscribir la memoria a terceros sin por ello modificar su sentido. Finalmente, la incapacidad de plenificar o confirmar esta atribución de terceros verificaría la última de las condiciones, es decir, la disimetría.

En lo referente al olvido, el filósofo partirá de la distinción entre el olvido fisiológico y el mnémico: el primero supone la desaparición de los trazos corticales sobre los que se apoyaba, en tanto que el segundo consiste en una situación de latencia de las huellas mnémicas hasta que procesos como el reconocimiento lo sacan de ese estado. De estos dos tipos de olvido, Ricoeur restringe su análisis al primero de ellos, donde "[...] hace falta que algo haya permanecido de la primera impresión para que recuerde ahora. Si vuelve un recuerdo, es porque lo había perdido, pero si pese a todo lo encuentro y lo reconozco, es porque su imagen había sobrevivido" (RICOEUR 2008b, p. 557). Al coincidir con Bergson en que el olvido y el reconocimiento no son explicables en términos neurológicos, ${ }^{16}$ Ricoeur considera que carece de sentido preguntarse acerca de dónde se almacena la memoria. La indagación propuesta en su lugar, cómo es posible el reconocimiento, es aplicable tanto para la memoria individual como colectiva (RICOEUR 2008b, p. 556).

\footnotetext{
inconsciente situado detrás de él, y la aparición y desaparición de lo escrito, con la conducta correspondiente de la conciencia en cuanto a las percepciones" (FREUD 1992, p. 246). Aunque no haya referencias sobre este escrito en la obra de Ricoeur es posible afirmar que el filósofo francés tomaría distancia sobre el sistema receptor por seguir manteniendo el vínculo causal de la marca inicial. Sin embargo, como veremos, su interés por el funcionamiento del inconsciente, lo hubiera llevado a profundizar en el segundo de los componentes. ${ }^{15}$ Cf. Ricoeur (1995, p. 6): "But to speak of memory is not only to evoke a psycho-physiological faculty which has something to do with the preservation and recollection of traces of the past; it is to put forward the 'narrative' function through which this primary capacity of preservation and recollection is exercised at the public level of language."

${ }^{16}$ Sobre la imposibilidad de identificar al cerebro como el lugar donde se fijan los recuerdos, cf. Bergson (1933, p. 134): "[...] no hay, no puede haber en el cerebro una región donde los recuerdos se fijen y se acumulen."
} 
Dado que la memoria es una capacidad, el análisis de Ricoeur se centra en determinar en qué consiste que la memoria cumpla con su función, y de no hacerlo, cómo lograrlo. Ricoeur denominará memoria feliz al cumplimiento de la capacidad mnémica: "A mi modo de ver, lo que importa es abordar la descripción de los fenómenos mnemónicos desde el punto de vista de las capacidades de las que ellos constituyen la efectuación 'feliz'" (RICOEUR 2008b, p. 40). Según Ricoeur, "[...] la estrella guía de toda la fenomenología de la memoria ha sido la idea de memoria feliz" (RICOEUR 2008b, p. 633). La memoria feliz sería aquella que cumple con su función propia, en contraposición a la incapaz de hacerlo porque cayó en la compulsión a la repetición. Teniendo en cuenta los atributos enumerados en el apartado anterior, la memoria feliz funcionaría de manera análoga al cuarto del hecho psicológico, según el cual la función propia de la memoria consiste en integrar los recuerdos en una historia de nuestra existencia, y a la vez plantea implícitamente un criterio económico de mejoría terapéutica. Al ubicar qué tipo de experiencia del pasado tiene la memoria, nos encontramos con un abordaje diferente del pasado. Aunque en Sí mismo como otro no se identificaba a la tematización del pasado con alguna experiencia del otro en particular, de las afirmación de Tiempo y narración, podemos colegir que ésta sería una experiencia del en tanto alteridad. En efecto, la representación histórica, en tanto representancia, se funda en la huella (RICOEUR 1996b, p. 839), y ella, en tanto "[...] es dejada por el pasado," (RICOEUR 1996b, p. 838) nos es extraña. En La memoria, la historia, el olvido, por el contrario, la memoria impedida, en tanto se enfrenta a sus pulsiones y compulsiones, se asocia con la experiencia del otro en tanto carne. De esta manera, gracias al desplazamiento del superyó al inconsciente en el psicoanálisis, y de la historia a la memoria traumatizada, Ricoeur logra encuadrar a ambas disciplinas dentro de la experiencia de lo otro en tanto carne.

Esta homogeneización de la experiencia del otro vuelve pertinente la introducción del pensamiento de Freud. Su primera aparición es durante la fenomenología de la memoria impedida, donde Ricoeur propone extender el alcance de las investigaciones sobre metapsicología, específicamente "Duelo y melancolía" y "Recordar, repetir y re-elaborar", a lo colectivo, "[...] no sólo en un sentido analógico sino en los términos de un análisis directo" (RICOEUR 2008b, p. 107). Ricoeur no sólo se siente avalando por la existencia de reinterpretaciones del psicoanálisis análogas a su propuesta, realizados por autores cercanos a la hermenéutica, como es el caso de Habermas, sino fundamentalmente porque considera que las categorías patológicas individuales son aplicables a nivel colectivo no sólo en "...estas situaciones excepcionales, sino que están ligadas a una estructura fundamental de la existencia colectiva" (RICOEUR 2008b, p. 108).

La pregunta que queda abierta es por qué extender a lo colectivo un análisis explícitamente anclado en el individuo, en lugar de tomar las aplicaciones culturales del psicoanálisis que el propio Freud lleva a cabo, como Tótem y tabú, Moisés y el monoteísmo, El advenir de una ilusión o El malestar de la cultura. En el caso de Tótem y Tabú Ricoeur señala que se trata de una interpretación 
analógica de lo colectivo, ${ }^{17}$ y no una trasposición directa, como la que él propone llevar a cabo. Sin embargo, considero que lo que motiva dicha preferencia es que en los conceptos de "trabajo de memoria" y "trabajo de duelo" está supuesta una concepción activa de la memoria afín con la que Ricoeur maneja. Sin embargo, la dificultad que tiene la ampliación de esta propuesta a lo colectivo, la planteó Ricoeur mismo en su obra sobre Freud. En aquel entonces, caracterizaba a los tratados de Metapsicología como el intento mejor logrado de creador del psicoanálisis por fusionar de manera armoniosa la economía pulsional con el lenguaje de sentido en la llamada primera tópica (inconsciente, preconsciente, consciente). Aunque ya en este período Freud había abandonado el lenguaje biologicista, en opinión de Ricoeur, la distinción de la primera tópica está asociada con la lógica pulsional, y por lo tanto, sigue estando sigue estando anclada en el individuo. ${ }^{18}$

El alcance de esta objeción hubiera sido mucho más limitado, si Ricoeur no hubiera realizado otra inclusión de la figura de Freud, en este caso como 'segundo abogado de lo inolvidable' (RICOEUR 2008b, p. 557). Así como sucedió en el caso de la definición de la memoria, las figuras de Freud y Bergson se vuelven a enfrentar en el análisis del olvido. En el caso de la memoria, Ricoeur se inclinó por el modelo bergsoniano de la memoria, fundada en el reconocimiento, frente a la pizarra mágica de Freud. De ahí, que el análisis del olvido comience con Bergson. Este filósofo define al olvido como el pasaje de la conciencia a la inconsciencia y la memoria es el camino inverso. En términos generales, la consciencia era definida como la disposición a actuar, la atención de la vida, en tanto lo inconsciente es su opuesto, es decir, aquello que está fuera de la preocupación cotidiana, que no actúa más directamente sobre nuestra vida: lo impotente. ${ }^{19}$ El problema de esta definición negativa de inconsciencia es que impide evaluar sus efectos en nuestra vida, es decir, la lógica detrás del olvido y la rememoración. A fin de suplir esta limitación de Bergson y proporcionar una lógica a estos pasajes, Ricoeur recurre a la concepción freudiana de inconsciente. En su opinión, la energética pulsional da cuenta de los vínculos entre consciencia e inconsciencia y proporciona las herramientas necesarias para resolver todas aquellas patologías que se presenten a nivel mnémico.

El problema no contemplado al inclinarse por Freud y que Ricoeur reconoció en su ensayo sobre Freud, es decir, que el uso de la cuestión energética y pulsional como explicación de la motivación del olvido supone la inclusión de los componentes del psicoanálisis más afines con explicaciones causalistas que

\footnotetext{
17 Cf. Ricoeur (1990, p. 174): "En este aspecto Tótem y tabú todavía pertenece al ciclo de interpretaciones 'analógicas' características del 'psicoanálisis aplicado'".

${ }_{18}$ Cf. Ricoeur (1990, p. 135): "La primera tópica seguía ligada a una económica de la pulsión, considerada como único concepto fundamental; sólo en relación con la libido la tópica se articulaba en tres sistemas. La segunda tópica es una económica de nueva índole: la libido es presa de algo diferente de ella, de una demanda de renuncia que crea una nueva situación económica; por eso pone en juego, no ya una serie de sistemas para una libido solipcista, sino una serie de papeles -personal, impersonal, suprapersonal- que son los de una libido en situación de cultura".

${ }^{19}$ Con respecto a la definición bergsoniana de inconsciente, cf. Bergson (1933, p. 153): "En otros términos, en el dominio psicológico, consciencia no sería sinónimo de existencia, sino solamente de acción real o de eficacia inmediata, y teniendo así limitada la extensión de este término, tendríamos menos problemas de representarnos un estado psicológico inconsciente, es decir, en suma, impotente".
} 
anclan a la memoria con la individualidad y de las que buscó deshacerse a lo largo de su fenomenología de la memoria.

\section{A manera de cierre}

A lo largo de estas páginas hemos señalado el proceso de convergencia que Ricoeur fue realizando a lo largo de su obra entre psicoanálisis e historia. El primer paso se fue dando entre las décadas setenta y ochenta en las que el filósofo reinterpretó al psicoanálisis desde una perspectiva hermenéutica, distanciándose así de sus propias posiciones presentadas en sus trabajos sobre la voluntad. La narrativización del análisis no alcanzó una lingüistización total, sino que el filósofo reivindicó la necesidad de una "epistemología mixta, mitad hermenéutica y mitad naturalista." Los otros dos pasos se produjeron con posterioridad a Si mismo como otro y se afianzaron en La memoria, la historia, el olvido. Durante ese período Ricoeur logró encuadrar a ambas disciplinas dentro de la experiencia de lo otro en tanto carne, gracias al desplazamiento del superyó al inconsciente en el psicoanálisis, y de la tematización de la memoria. La patologización de la historia, por su parte, estuvo asociada con haber definido a la memoria como una capacidad, y plantear como aspiración para el historiador, el logro de una memoria feliz, es decir, una memoria capaz de recordar. Este logro presupone la existencia de memorias incapaces, entre otros motivos, impedidas por limitaciones patológicas que la conduce a la compulsión a la repetición.

En este trabajo nos hemos detenido particularmente en la memoria impedida y los medios de resolverlo, es decir, en la labor 'psicológica' del historiador. Básicamente hemos sostenido que la doble epistemología freudiana reivindicada por Ricoeur, y específicamente la economía pulsional, constituye el gran obstáculo para la colectivización de las categorías analíticas. Desde este punto de la investigación se nos ocurren dos caminos alternativos para salvar esta barrera. La primera consiste en abandonar toda explicación físicalista acerca de la memoria. Pese a conducirlo a un monismo epistemológico, podría desarrollar una hermenéutica de la memoria colectiva, más afín al análisis lacaniano, o incluso reforzar la otra de las líneas de los abusos de la memoria presentada en esta obra, a saber: la memoria manipulada, cuya vía de resolución sería a través de una crítica a las ideologías, cercana a la obra de Habermas. La segunda alternativa sería llevar retrotraerse a los presupuestos ontológicos de estos análisis, específicamente en la temporalidad, la estructura de articulación entre la historia y el psicoanálisis freudiano. Para transitar este camino se podría recurrir a las consideraciones temporales de la historia hechas por el propio Ricoeur, y a algunos acercamientos temporales al psicoanálisis. Estoy haciendo referencia específicamente a investigaciones como las de Muriel Gilbert, quien hace unos años propuso una estrategia de esta naturaleza, al sostener "¿Binswanger y Minkowski no nos han enseñado a considerar las afecciones psíquicas entre otros bajo el ángulo de su relación con el tiempo? [...] Se trataría en este sentido de interrogar al sujeto de las repercusiones posibles de las patologías mencionadas de la relación del tiempo sobre la identidad narrativa" (GILBERT 2001, p. 19). 


\section{Referencias bibliográficas}

BERGSON, Henry. Matière et mémoire. Essai sur la relation du corps à l'esprit. Paris: Alcan, 1933.

BUSACCHI, Vinicio: Entre narration et action: Herméneutique et reconstruction thérapeutique de l'identité. Études Ricoeuriennes / Ricoeur Studies, v. 1, n. 1, p. 21-33, 2010.

CARUTH, Cathy. Unclaimed Experience: Trauma, Narrative and History. Baltimore and London: The Johns Hopkins University Press, 1996.

DOSSE, François. Paul Ricoeur. Le sens d'une vie (1913-2005). Paris: La Découverte, 2008.

FELMAN, Shoshana; LAUB, Dori. Testimony - Crises of Witnessing in Literature, Psychoanalysis, and History. London: Routledge, 1992.

FREUD, S. Obras Completas (1923-25), Buenos Aires: Amorrortu, 1992. v. XIX.

GILBERT, Muriel. L'identité narrative. Une reprise à partir de Freud de la pensée de Paul Ricoeur. Genève: Labor et Fides, 2001.

KEARNEY, Richard. Poetics of Imagining: from Modern to Postmodern. Edinburgh: Edinburgh University Press, 1998.

Ricoeur's Wager of Flesh: Between Phenomenology and Hermeneutics. In: SAVAGE W. H. Paul Ricoeur in the Age of Hermeneutical Reason. Poetics, Praxis and Critique. Lanham; Boulder; New York; London: Lexington Books, 2015, p. 179-190.

LACAN, Jacques. El seminario. Libro 5, Las formaciones del inconsciente. Buenos Aires: Paidós, 1999.

El seminario. Libro 7, La ética del psicoanálisis. Buenos Aires: Paidós, 1988.

LACAPRA, Dominick, Writing History, Writing Trauma. Baltimore; London: The Johns Hopkins University Press, 2001.

LAPLANCHE, J, El psicoanálisis como anti-hermenéutica. Zona Erógena, n. 30, 1996.

LYTHGOE, E, El rol político del historiador y el papel de la imaginación productiva en su labor. Astrolabio - Revista Internacional de Filosofía, n. 26, p. 26-40, 2015.

RICOEUR, Paul. Philosophie de la volonté. Le volontaire et l'involontaire. Paris: Aubier, 1950. t. 1.

. La psychanalyse confrontée à l'épistémologie. Psychiatrie Française, n. spécial, 1986. Disponible en: http://www.fondsricoeur.fr/uploads/ medias/articles_pr/psychanalyse-confrontee-epistemologie.pdf. Acceso en: 10 oct. 2016. 
. Freud: una interpretación de la cultura. México: Fondo de Cultura Económica, 1990.

. Reflections on a new ethos for Europe. Philosophy and Social Criticism. v. 21, n. 5/6, p. 3-13, 1995.

. Le pardon peut-il guérir? Esprit, v. 210, n. 3/4, p. 77-82, 1995b.

. Sí mismo como otro, Buenos Aires: Siglo XXI, 1996.

. Tiempo y narración III, Buenos Aires: Siglo XXI, 1996b.

. Le récit: sa place en psychanalyse. In: Écrits et conférences

1. Autour de la Psychanalyse. Paris: Seuil, 2008.

. La memoria, la historia, el olvido. Buenos Aires: Fondo de Cultura Económica, 2008b.

. Anthropologie philosophique. In: Écrits et conférences 3.

Paris: Seuil, 2013.

SEDAT, Jacques. Ricoeur, Freud et la démarche psychanalytique. In: DELACROIX,

C.; DOSSE, F.; GARCIA, P. Paul Ricoeur, et les sciences humaines. Paris: La Découverte, 2007.

WHITE, Hayden. Guilty of History? La longue durée of Paul Ricoeur. History and Theory, n. 46, p. 233-251, 2007. 
1000000 


\title{
As propostas culturais, econômicas e políticas apresentadas nas primeiras Conferências Pan- Americanas
}

\author{
The cultural, economic and political proposals presented in the first \\ Pan-American Conferences
}

DULCI, Tereza Maria Spyer. As Conferências Pan-Americanas (1889 a 1928): Identidades, União Aduaneira e Arbitragem. São Paulo: Alameda, 2013. 238p.

\section{Paulo Alves Pereira Júnior}

paulopereira_pf@hotmail.com

Mestrando em História - Bolsista FAPESP

Universidade Estadual Paulista (UNESP - Assis)

Rua João M. Salgueiro, 63 , Ed. Antônio Gallo, ap. 03

13660-000 - Porto Ferreira - São Paulo

Brasil

Palavras-chave

História da América; Historiografia latino-americana; Historiografia norte-americana.

Keywords

American historiography; Latin American historiography; American historiography. 
A criação do Mercado Comum do Sul e da União das Nações Sul-Americanas estimulou o debate acerca das relações de aproximações e distanciamentos entre o Brasil e os outros países americanos e, também, das probabilidades de integração econômica, política e cultural no continente. Para compreender tal movimento, Tereza Maria Spyer Dulci elaborou uma dissertação, apresentada à Universidade de São Paulo (USP) em 2008, que analisou a participação brasileira nas seis primeiras Conferências Pan-Americanas. Utilizando-se de uma sólida documentação, a autora externou dois temas amplamente discutidos nesses congressos: a União Aduaneira e a arbitragem. Ademais, destacou as propostas identitárias elucidadas pelos Estados Unidos da América (EUA) e pela Argentina. Buscando alcançar um público-leitor além do círculo acadêmico, esse trabalho foi transformado em livro no ano de 2013. As Conferências Pan-Americanas (1889 a 1928): identidades, união aduaneira e arbitragem foi publicada pela editora Alameda e pertence à coleção Teses do Programa de Pós-Graduação em História Social da USP.

Fracionado em quatro capítulos, a obra inicia-se com um texto introdutório, o qual destaca o escopo do estudo, realiza um balanço bibliográfico a respeito das Conferências Pan-Americanas e apresenta a abordagem teórica utilizada, pautada no campo da História Política e nas perspectivas enunciadas pela crítica pós-colonial. No primeiro capítulo, a autora explana a trajetória dos seis primeiros conclaves, evidenciando seus principais objetivos e resultados. Já no segundo, analisa os projetos identitários constituídos durante as conferências estudadas e o posicionamento da diplomacia brasileira a respeito de tais discursos. As discussões referentes à união aduaneira e às propostas integracionistas apresentadas nessas assembleias são abordadas no terceiro capítulo. Os debates sobre a utilização do arbitramento como uma forma de solucionar os conflitos internacionais foram elucidados no último capítulo.

As Conferências Pan-Americanas ocorreram entre 1889 e 1948 e tiveram como sede, respectivamente, as cidades de Washington, Cidade do México, Rio de Janeiro, Buenos Aires, Santiago, Havana, Montevidéu, Lima e Bogotá. O objetivo dessas assembleias era unir os países americanos através do fortalecimento político-econômico no continente. Após o fim da Guerra de Secessão (18611865) e da Guerra Hispano-Americana de 1898, o eixo da política externa estadunidense moveu-se para a América Central e o Caribe. Ademais, esse movimento pretendeu transformar o país no líder continental. Para lograr com tal proposta, ao final do século XIX os EUA convidaram as outras nações americanas para um evento que tratasse de questões relacionadas ao comércio internacional e à arbitragem nas disputas regionais. Dessa forma, realizou-se entre 02 de outubro de 1889 e 19 de abril de 1890 a Primeira Conferência Pan-Americana. Contando com a participação de dezoito delegações, o evento discutiu a adoção da arbitragem, o desenvolvimento comercial entre os países e a elaboração da união aduaneira. Por conta da postura opositora da delegação argentina, grande parte dessas propostas foi derrotada.

Sucedeu-se na Cidade do México, de 22 de outubro de 1901 a 22 de janeiro de 1902, a Segunda Conferência, formada por dezenove delegações. 
Debateu-se alguns pontos da assembleia passada e assuntos relacionados aos meios de proteção industrial e comercial, além de outros temas. Ao final, aprovou-se resoluções associadas ao arbitramento e ao direito internacional. 0 conclave posterior ocorreu no Rio de Janeiro entre 23 e 27 de agosto de 1906 e foi composto por dezenove delegações. Esgrimiu-se a questão do arbitramento, das dívidas públicas, da codificação do Direito Internacional Público e Privado, das leis aduaneiras e consulares, da polícia sanitária, da estrada de ferro panamericana e da propriedade literária. A assembleia findou-se com a aprovação de tratados de reciprocidade comercial entre os países americanos e resoluções acerca dos direitos autorais.

De 12 de julho a 27 de agosto de 1910, vinte delegações reuniram-se Buenos Aires para a quarta edição do evento. Discutiu-se o intercâmbio de professores e de estudantes e a comemoração do centenário de independência dos países hispano-americanos, dentre outros temas. O principal logro desse encontro foi a ratificação dos assuntos debatidos no conclave anterior e a aprovação das resoluções sobre os direitos autorais, as patentes, a saúde pública e o direito internacional. Em função da Primeira Guerra Mundial, a Quinta Conferência foi realizada após um intervalo de treze anos. Dezoito delegações fizeram parte dessa convenção, ocorrida entre 25 de março e 03 de maio de 1923 em Santiago. Abordou-se as medidas preventivas de enfermidades infecciosas, a promoção de arbitragem comercial entre cidadãos de diferentes países e o acordo sobre leis e regulamentação da comunicação marítima, terrestre e aérea.

A assembleia seguinte ocorreu em Havana de 16 de janeiro a 20 de fevereiro de 1928 e contou com a participação de vinte e uma delegações. Os principais assuntos abordados foram a União Pan-Americana, os problemas comunicacionais e socioeconômicos e a ordem jurídica interamericana. O resultado fundamental desse encontro foi a aprovação do Código de Direito Internacional Privado Americano que estabeleceu uma normativa geral para evitar conflitos entre as leis nacionais e internacionais.

As seis assembleias proporcionaram uma rede de solidariedade regional e desenvolveram um espaço de disputa entre as nações americanas. Em tais conclaves, apesar de ter existido um protagonismo estadunidense que privilegiou pautas de seus interesses e manteve uma política de troca de votos - nos bastidores - por acordos comerciais e de intervenção e anexação de territórios na América Latina e no Caribe, muitos países latino-americanos rechaçaram as propostas que poderiam prejudicá-los.

Nas Conferências Pan-Americanas configurou-se duas construções identitárias: o pan-americanismo e o latino-americanismo. O primeiro era o oficial das assembleias, constituído pelos delegados estadunidenses. Para construir uma identidade continental, os Estados Unidos apresentaram projetos de financiamento e intercambio entre as universidades da região com o objetivo de aprofundar as investigações sobre os elementos histórico-culturais da América e legitimar um passado comum. Por sua vez, o segundo discurso foi propagado pelos representantes argentinos nas reuniões com a intenção de impedir as intervenções dos EUA e de direcionar a Argentina à liderança 
da América Latina. Essa proposta abrangeu as nações latino-americanas que atuaram nas assembleias e excluiu os países não hispânicos.

Sobre as disputas de identidades, a diplomacia brasileira adotou uma postura neutra, aproximando-se do discurso pan-americano ou latino-americano quando Ihe convinha. Para aumentar sua influência nas conferências, o Brasil acercou-se dos Estados Unidos, como ocorreu no caso do arbitramento. Em outras ocasiões, avizinhou-se dos outros países da América Latina, principalmente quando envolvia interesses econômicos, como a proposta de união aduaneira. Esse movimento ficou conspícuo nos conflitos travados entre Joaquim Nabuco, que defendeu veementemente o pan-americanismo e a liderança estadunidense no continente, e Manoel de Oliveira Lima, que criticou o projeto identitário fomentado pelos Estados Unidos e afirmou que o Brasil deveria relacionar-se mais com os Estados ibero-americanos para conter a política intervencionista dos EUA.

A temática sobre a união aduaneira surgiu antes das Conferências PanAmericanas, uma vez que existiram projetos de pacto regional desde o início do século XIX. Nesse período, diversos tratados de navegação, de comércio e de alianças foram assinados pelas nações americanas. Por conta dos conflitos internos, os Estados Unidos não participaram desses acordos. Após a Guerra da Secessão, a diplomacia estadunidense desenvolveu uma política econômica que pretendeu escoar seus produtos nos mercados americanos. Na assembleia de Washington, os EUA incluíram uma pauta no programa que discutiu a elaboração de uma união aduaneira que englobasse todo o continente sem barreiras físicas ou materiais entre os territórios nacionais para que bens, capitais e serviços circulassem.

O governo estadunidense esperava que sua proposta fosse bem recebida pelas delegações dos outros países, o que não ocorreu, já que foi duramente criticada pelos representantes chilenos e argentinos e observada com desconfiança pelos outros delegados que acreditavam que tal medida poderia prejudicar os acordos bilaterais na região. Apesar de a questão não ter logrado em tais congressos, o tema relacionado à união aduaneira fez parte de muitos debates diplomáticos do final do século XIX e das primeiras décadas da centúria passada.

Nas conferências posteriores, os Estados Unidos centralizaram suas discussões em torno dos tratados comerciais bilaterais que auxiliassem no escoamento de suas mercadorias para os países latino-americanos e debateram as propostas de união aduaneira nas entrelinhas dos programas, com o intuito de diminuir o impacto da derrota na primeira assembleia. Dessa forma, incentivaram a elaboração de alianças de reciprocidade e projetos integracionistas, objetivando facilitar a constituição de uma união aduaneira.

Pretendendo fomentar o desenvolvimento das relações econômicas entre as nações americanas, discutiu-se nos conclaves os seguintes projetos: Câmaras de Comércio e Propaganda; Sociedades Anônimas; Banco Pan-Americano; União Monetária; Regulamentos Aduaneiros; Codificação do Direito Internacional Público e Privado; Código Sanitário; Regulamentação da Propriedade Literária e Artística, Patentes e Marcas de Fábrica e Comércio; e Estrada de Ferro PanAmericana. Tais propostas não foram consideradas praticáveis por todos os 
delegados presentes nos eventos, apesar de elas levarem em consideração os interesses particulares de cada nação.

O tema do arbitramento tornou-se uma questão central nas conferências. Ao final do século XIX, havia um conflito de influências entre os países que não aceitavam ter o seu poder inferiorizado no continente americano, como a Inglaterra - representada pelos delegados argentinos - e a ambição estadunidense de intervir nos países latino-americanos e caribenhos. Além disso, os EUA pretendiam se tornar os árbitros nas disputas entre as nações da América Latina, substituindo a Europa e assegurando sua influência política. Desde o conclave da Cidade do México, debateu-se sobre a adoção da arbitragem obrigatória ou voluntária, tendo a Argentina defendida a primeira ramificação e os Estados Unidos endossado a segunda. Dessa forma, os Estados americanos possuíam distintas posições, uns aceitando e outros rechaçando o arbitramento. Tais posturas foram determinadas pelos interesses particulares de cada país.

Os Estados Unidos apresentaram uma posição dúbia em relação ao tema, uma vez que defendiam a paz na região desde que os conflitos fossem gerenciados por eles e, caso houvesse a necessidade de garantir a paz em alguma nação, valer-se-iam do "direito de conquista". Já o Brasil utilizou esse recurso para resolver os litígios pendentes acerca da delimitação fronteiriça. Por sua vez, a Argentina envolveu-se nessas discussões para diminuir o avanço da influência político-econômica dos EUA na América Latina. Na Conferência de Washington foi assinado um tratado estabelecendo a arbitragem como um princípio do Direito Internacional Americano para as divergências entre as nações americanas. Além disso, elucidava a questão do arbitramento envolvendo os países americanos e os Estados europeus.

Entretanto, tal documento não foi ratificado pelos membros do conclave e discutiu-se a elaboração de um tratado que garantisse às partes em litígio o direito de submeterem reclamações por danos pecuniários não solucionados por meios diplomáticos. Amplamente debatido nos eventos, o assunto relacionado à arbitragem malogrou com a eclosão da Primeira Guerra Mundial. O projeto conciliador do arbitramento elucidado nas Conferências Pan-Americanas era tênue e, por essa razão, não obteve consenso entre os participantes.

Tereza Maria Spyer Dulci destaca que, ao contrário do que a bibliografia sobre o assunto elucida, os Estados Unidos não tiveram suas propostas totalmente aceitas nas assembleias, já que os debates sobre a união aduaneira e a arbitragem não surtiram os efeitos esperados. Dessa forma, compreende as Conferências Pan-Americanas como locais que acolheram conflitos entre o "centro" de poder estadunidense e a oposição das "periferias" latino-americanas e caribenhas.

A autora apresenta ao público-leitor uma pesquisa original que contou com diversas fontes e com uma vasta bibliografia em língua espanhola, inglesa e portuguesa. A maioria dessas fontes é composta por documentos elaborados pelo Ministério das Relações Exteriores do Brasil, como ofícios, dossiês, telegramas, recibos, recortes de reportagens jornalísticas, protocolos, dentre outros. Tais materiais foram encontrados no Arquivo Histórico do 
Itamaraty, na cidade do Rio de Janeiro, no Centro de Documentação e Divisão de Comunicações e Arquivo do Ministério das Relações Exteriores do Brasil, em Brasília, e na Biblioteca Embaixador Antonio Francisco Azeredo da Silveira, também localizada na capital brasileira.

Apesar dos méritos, o trabalho necessita de uma discussão mais aprofundada acerca das propostas de identidade, da elaboração de união aduaneira e dos projetos de arbitragem nas Conferências Pan-Americanas. Ademais, seria necessário levar em consideração a perspectiva de outros países americanos que participaram dessas assembleias, a fim de constatar o impacto desses eventos em suas políticas diplomáticas, econômicas e culturais. A eclosão da Guerra do Chaco (1932-1935), conflito bélico entre Bolívia e Paraguai, fomentou a polêmica em torno do arbitramento? Qual a importância da Confederación Universitaria Centroamericana, fundada em 1948, para os projetos integracionistas do continente? A criação da Associação Latino-Americana de Livre Comércio, na década de 1960, foi influenciada pelas discussões apresentadas nas conferências? Tais questões podem ser esclarecidas em investigações futuras sobre o tema em questão. 


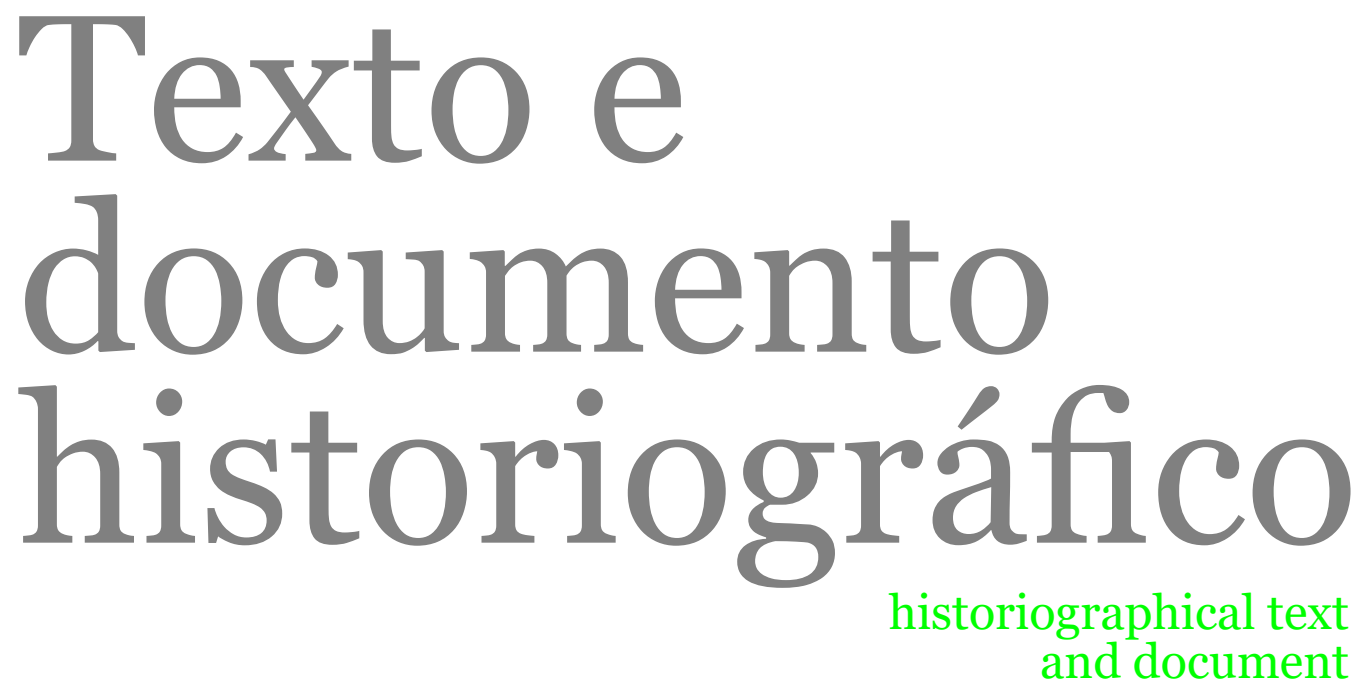




\title{
A nostalgia como problema metahistórico: uma introdução
}

Nostalgia as a meta-historical problem: an interpretation

\author{
André de Lemos Freixo \\ andredelemos@gmail.com \\ Professor Adjunto \\ Universidade Federal de Ouro Preto \\ Rua do Seminário, s/n \\ 35420-000 - Mariana - MG \\ Brasil \\ Marcelo Santos de Abreu \\ orientacaoufop@gmail.com \\ Professor Adjunto \\ Universidade Federal de Ouro Preto \\ Rua do Seminário, s/n \\ 35420-000 - Mariana - MG \\ Brasil \\ Sérgio da Mata \\ sdmata@ichs.ufop.br \\ Professor Adjunto \\ Universidade Federal de Ouro Preto \\ Rua do Seminário, $\mathrm{s} / \mathrm{n}$ \\ 35420-000 - Mariana - MG \\ Brasil
}

138

Palavras-chave

Nostalgia; Modernidade; História.

Keywords

Nostalgia; Modernity; History.

Recebido em: 10/4/2017

Aprovado em: 2/5/2017 
A nostalgia faz parte do repertório básico de experiências humanas. Ela pode ser encontrada nas mais diferentes épocas e lugares, a despeito do esforço, não menos recorrente, de se lhe emprestar certo colorido local. As perspectivas sob as quais se pretendeu explicá-la e descrevê-la remontam ao alvorecer da ciência moderna. Desde Johannes Hofer, o interesse por esta mistura de idealização retrospectiva e topofilia tem ocupado gerações de estudiosos, de Jacob Grimm a Roberto DaMatta. Da Heimweh dos antigos mercenários suíços ao banzo dos africanos trazidos à força para o novo mundo, muito já se escreveu a respeito da nostalgia.

Os historiadores são em geral pouco interessados pelo fenômeno da nostalgia. Por vezes o termo "nostálgicos" é empregado no sentido de marcar os "conservadores", num movimento complexo no qual tais conceitos são empregados de modo intercambiável. Os textos a seguir, por nós traduzidos, procuram convidar os historiadores brasileiros a prestar a devida atenção à abertura de possibilidades - não só teóricas, mas políticas - sugerida pela leitura dos ensaios de Arnold Gehlen e Svetlana Boym.

Depois da grande leva de publicações nos últimos anos sobre as experiências de trauma coletivo, talvez seja chegada a hora de nos ocuparmos com modalidades menos extra-cotidianas de presença do passado. Ao contrário do que se convencionou a respeito do conceito de trauma, entendido como uma ferida aberta e uma dor que não passa, um "passado" que insiste em não passar, a nostalgia não carece de "tratamento". Ela não precisa ser trabalhada, reprimida ou sublimada, pois trata-se de um sentimento distinto da dor traumática, ela representa uma melancolia que, paradoxalmente, se sente com algum prazer.

Para além das tradicionais análises médicas, psicológicas e literárias do fenômeno, um de nossos autores traduzidos, Arnold Gehlen, propôs sua "interpretação histórico-política" da nostalgia numa época em que o tema aparentemente não fazia sentido algum no campo da sociologia. Publicado no ano de sua morte, este texto de 1976 destoa completamente do Zeitgeist daquela época, um momento em que o otimismo das filosofias da história ainda parecia amplamente amparado pelos fatos. Embora fosse um dos mais influentes intelectuais conservadores alemães (o que não impediu que Adorno, Lukács, Blumenberg, Luhmann e Honneth recorressem com frequência aos seus escritos), Gehlen nunca se notabilizou por uma sensibilidade especial em relação à história. Enquanto o outro grande nome da antropologia filosófica, Helmuth Plessner, caracteriza o ser humano como constitutivamente apátrida e como "uma questão em aberto", para Gehlen o humano é um ser de carências, e a cultura uma jaula feita de hábitos e instituições. Em Plessner o ser humano é todo possibilidade, e seu lugar um lugar utópico. Em Gehlen, ele é um ser carente de estabilidade e orientação. Ainda que as duas visões se complementem, é curioso que a nostalgia e o advento de surtos nostálgicos possam ser melhor compreendidos por meio da teoria daquele que, dentre os pais da antropologia filosófica, menos se interessou pela história. O conceito de posicionalidade excêntrica, cunhado por Plessner para descrever a condição humana, tanto quanto a tradicional noção de Bildung, encontram aqui os seus 
limites. Configurando-se como uma segunda natureza, a cultura exerce uma força centrífuga que nos reconduz e por vezes encarcera num espaço e tempo específicos (se idealizados ou não, pouco importa) cujo abandono é, não raro, doloroso. Para Gehlen o ser humano está condenado a essa dor, razão pela qual suas reflexões se iniciam pelo tema da felicidade. Nostalgia e utopia vivem às custas da ilusão de que a plenitude existiu, ou há de existir um dia.

Os estrategistas das indústrias do audiovisual e fonográfica, ao que parece, perceberam-no antes de nós. A entropia temporal que marca as sociedades contemporâneas se revela, entre outras coisas, no prestígio compensatório do vintage e do second hand, situação que o rapper Prinz Pi traduziu nesses versos: gostaríamos tanto de estar no ontem / vivemos segundo a fórmula "quanto mais retrô, mais novo". Recentemente, o cineasta brasileiro João Moreira Salles afirmou em entrevista que "a nostalgia mata". Ele se referia à visão dominante em certos meios, envolta numa densa névoa romântica, que ainda hoje cerca os eventos do maio de 1968. Tal juízo expressa uma dificuldade que não seria o caso de dramatizar. Por uma questão não apenas de princípios, mas também de empatia, os intelectuais conservadores estão muitas vezes mais próximos de compreender a nostalgia e inclusive de torná-la esteticamente produtiva. É o caso de Arnold Gehlen, que já em meados da década de 1960 defendia a tese de que o mundo contemporâneo passou por um processo de cristalização cultural, adentrando com isso a era da posthistoire. É também o caso de Andrei Tarkovski, cujo notável filme Nostalghia, de 1983, pode ser visto como a versão

140 cinematográfica dos diagnósticos de Gehlen. À época, um colunista do New York Times, se bem que com intenção crítica, resumiu Nostalghia em duas palavras: "nothing happens".

De um filme mais recente e de enorme sucesso, Adeus Lenin!, pode-se dizer outra coisa: tudo acontece novamente. Svetlana Boym lembra esse filme para indicar o artificialismo que pode constituir a cultura nostálgica contemporânea como resposta à crise de futuro experimentada nas últimas décadas. Em sua interpretação, ela se encontra com intelectuais conservadores e progressistas ao apontar a relevância do fenômeno para a compreensão do nosso mundo. Encontro revelado igualmente na identificação da nostalgia à modernidade, e especialmente o lugar que a utopia - a busca da felicidade, diria Gehlen ocupa no mundo moderno. No entanto, Boym distingue alguma positividade na nostalgia como fenômeno que não se reduz necessariamente a um passadismo compensatório - ao contrário de um intelectual progressista como Andreas Huyssen, que no mesmo momento fazia a crítica da produção mercantil da nostalgia como um indício de certo aprisionamento em um presente carregado de passados e carente de futuro.

O texto de Boym, que resume as principais hipóteses sobre a nostalgia desenvolvidas no livro The Future of Nostalgia (2001), se situa no campo de reflexão sobre o suposto fechamento do horizonte de expectativas na contemporaneidade. Reflexões que ensejaram os diagnósticos - a palavra aqui não é inocente - sobre o que seria a crise de futuro: ela estaria a indicar uma nova ordem do tempo, o presentismo como novo regime de historicidade ou 
o presente amplo como evidência de esgotamento do cronótopo historicista (para ficarmos apenas nas proposições que ganharam relevância entre nós). Boym partilha dessas percepções, algumas claramente nostálgicas, de certo mal estar na contemporaneidade provocado pela produção massiva de passados em nosso tempo.

O que ela traz de novo para o debate, porém, são as distintas possibilidades da cultura nostálgica contemporânea. Em um primeiro sentido, como já apontamos, a nostalgia é contemporânea da utopia como traço moderno e que precisa ser pensada em sua dimensão espaço-temporal. Por outro lado, Boym não a vê como necessariamente oposta à utopia - um dos mais instigantes insights em sua análise. A autora procura identificar duas modalidades da nostalgia: a restauradora e a reflexiva. Ambas transcendem diferentes paisagens e nomes próprios que a nostalgia possa ganhar. Realizam-se em diversos contextos políticos, intercambiam-se certamente, embora a autora não demonstre exatamente como isso se dá ao marcar as diferenças entre uma e outra. As duas produzem e atualizam formas estéticas próprias que configuram, por sua vez, contornos éticos precisos. Em sua prosa elegante, Boym nos faz ver que a nostalgia reflexiva assume a contingência e não procura deter a mudança, ao passo que a nostalgia restauradora evoca o passado, especialmente o passado grandioso das idades de ouro nacionais - diferença que parece hierarquizar cada uma delas na tipologia. A primeira "temporaliza o espaço", a segunda "espacializa o tempo", do que podemos inferir duas posturas distintas: ver num lugar, mesmo no desterro, as camadas de tempo e história que se misturam e podem inspirar o novo ou inscrever no presente a marca de um lugar pretérito hegemônico, sempre idêntico a si mesmo. A última quer fazer do presente um lugar para o futuro do passado, configurando, por assim dizer, uma utopia conservadora como aquela imaginada por Ernst Jünger em seu romance distópico Eumeswil, de 1987. A primeira, ao contrário, faz do passado uma inspiração para um futuro aberto, recobrando, talvez, o sentido das utopias futuristas e do "princípio esperança".

Não é o caso, nessa introdução, de nos estendermos muito no delineamento das características da nostalgia para os dois autores, nem de marcar as diferenças de fundo que há entre eles - o que de fato já se evidencia nessas notas breves. Esperamos que as leituras dos textos provoquem a reflexão sobre os passados presentes não apenas a partir do que já conhecemos e controlamos racionalmente, mas também a partir de um sentimento a que estamos naturalmente inclinados: a saudade. 


\title{
A felicidade evadida. Uma interpretação da nostalgia*
}

\author{
Happines evaded. An interpretation of nostalgia
}

\section{Arnold Gehlen}

Para me aproximar de meu tema será necessário fazer um desvio, e em especial algumas observações sobre o tema de todas estas contribuições: a felicidade. Chama a atenção do sociólogo que de certa maneira se cumpriu a reivindicação, surgida no século XVIII, de uma felicidade terrena para todos. Em suas origens esta ideia pareceu exagerada e gozou de pouca credibilidade. Caso se estabelecesse como objetivo último a satisfação das necessidades de todos os seres humanos em um determinado patamar, tal coisa seria possível. Mas em uma sociedade regida por filósofos, como a sonhada por Platão, a felicidade estaria numa situação diferente e, felizmente, há poucas chances de que possamos ainda vivenciar tal coisa.

Ao contrário: por toda a parte vemos como a ideia de felicidade se introduz no ideal de bem-estar, visto como condição de nossas reivindicações. O sociólogo Götz Briefs afirma já em 1926, em seu ensaio "O proletariado industrial", que o núcleo da transformação ética da Era Moderna assentaria na eticização do ideal de bem-estar (BRIEFS 1926).

Eticização significa aqui algo diferente. Em primeiro lugar, é uma prioridade da demanda por satisfações de todo tipo e que se vive com a consciência limpa; embora o destinatário das demandas individuais seja a sociedade ou o Estado. Em segundo lugar, este anseio de felicidade se antepõe às demandas que o Estado poderia nos colocar, embora as pessoas empreguem de bom grado a fórmula segundo a qual o Estado está em função delas e não o contrário. Em terceiro lugar, a divisão desigual dos bens garantidores de felicidade é percebida como uma injustiça e mesmo como a mais fundamental das injustiças. E em quarto, perdem credibilidade e caráter de exemplaridade todas aquelas situações em que se exigem mais sacrifícios que direitos.

Todas essas inovações no campo dos valores remontam ao século XVIII, são filhas do Iluminismo. Isso foi demonstrado por Jacob L. Talmon no livro "As origens da democracia totalitária". O jacobino Gracchus Babeuf, ele próprio guilhotinado em 1797, exigiu: "Garantam a cada cidadão individual um nível de

\footnotetext{
* Arnold Gehlen (1904-1976) foi professor de filosofia das universidades de Leipzig e Königsberg. Depois da Segunda Guerra, lecionou sociologia e psicologia nas escolas superiores de Speyer e Aachen. Seus principais livros são O ser humano (1940), Ser humano primitivo e civilização tardia (1956), Imagens de época (1960) e Moral e hipermoral (1969). O ensaio aqui traduzido foi publicado originalmente com o título "Das entflohene Glück. Deutung der Nostalgie", em: HOMMES, Ulrich (Hg.). Was ist Glück? Ein Symposion [O que é felicidade? Um simpósio]. München: Fischer, 1976, p. 26-38; e também na revista Merkur, v. 30, n. 5, p. 432-442, 1976. Empregou-se a versão disponível na Arnold Gehlen Gesamtausgabe VI. Frankfurt am Main: Klostermann, 2004, p. 552-565. O tradutor Sérgio da Mata expressa seus agradecimentos ao editor geral das obras completas de Gehlen, Prof. Karl-Siegbert Rehberg, pela autorização para a publicação desta versão em português.
} 
felicidade permanente, a satisfação das necessidades de todos e um rendimento fixo, independentemente de suas incapacidades, de sua imoralidade ou das más intenções dos poderosos" (apud TALMON 1961, p. 178). A última revolução (a de 1789), dizia ele, evidentemente não fora ainda concluída porque não tinha realizado a felicidade geral (TALMON 1961, p. 190).

Mas o ideal aqui caracterizado é problemático em seus limites tanto para cima quanto para baixo. O nível de bem-estar não deve ser elevado de maneira tão descabida caso queira parecer realizável. Também não se pode negar que, enquanto tal, a ânsia por felicidade é antipolítica porque, do ponto de vista político, existem Estados bem-sucedidos e com grande autoridade que fomentam em si e em seus cidadãos objetivos políticos ambiciosos, e que deles exigem que abram mão do que não pode ser realizado, posto que não fazem da edificação do bem-estar a maior das prioridades.

Foi aliás por estas razões políticas que, diante das guerras de coalizão contra a França, Saint-Just e Robespierre se viram obrigados a diminuir significativamente as suas expectativas. Saint-Just achava que a soma da virtude a um pedacinho de terra poderia garantir a felicidade, que consistiria no gozo do necessário sem fartura. "Um arado, um pedaço de terra e uma casinha, distante da ganância do assaltante, é ali que está a felicidade" (apud TALMON 1961, p. 148).

Surge aqui, talvez pela primeira vez, a ideia de uma primitivização consciente do padrão de vida coletivo com o objetivo de se elevar o poderio militar nacional que, desde então, rejuvenesceu de diversas formas e sob diferentes palavras de ordem. Caso a prioridade do bem-estar tivesse de ser sacrificada, que fosse sob a famosa fórmula "quereis manteiga ou canhões?"

Nos últimos tempos e depois que a pax americana logrou erigir sempre novas pirâmides de reivindicações e para as quais a palavra "qualidade de vida", em sua franqueza, é ainda mais característica, surpreende que inclusive nas opulentas sociedades industriais um número não desprezível de pessoas abra mão de suas necessidades de consumo. Por meio de um padrão de vida pronunciadamente simples se atinge com facilidade um fortalecimento do ideal de liberdade, no sentido de uma independência interna e externa. O conhecido psicólogo Peter $\mathrm{H}$. Hofstätter mostrou que $25 \%$ dos estudantes universitários do sexo masculino são avessos ao trabalho e inclinados a deixar o emprego, demonstrando ódio e repulsa pela ideia de terem uma profissão. À ideia de profissão eles associam termos como avareza, escravidão, nojo, miséria (HOFSTÄTTER 1972, p. 108 e ss.).

A interpretação não é fácil. Pode ser que se trate de verdadeiros preguiçosos, mas também de pessoas com concepções atípicas de felicidade, que talvez se coloquem politicamente em luta contra a sociedade de consumo capitalista, ou que apesar da eticização do bem-estar em nossa sociedade percebem um deficit de ideais que elas não querem que seja satisfeito apenas retoricamente. Somente depois de novas pesquisas será possível saber qual dessas hipóteses é a mais correta.

Já indiquei o limite superior da ideologia do bem-estar. Como se sabe, é móvel o patamar abaixo do qual se pode falar em carência e acima do qual em 
excesso. Com efeito, todos se acostumam ao nível mais alto atingido, que se torna autoevidente e, deste modo, um ponto zero a partir do qual se começa a contar novamente e a partir do qual novos índices de prosperidade se tornam visíveis. Esta é a razão pela qual toda classe de endinheirados inveja apenas a camada que se situa acima dela e porque somente poucas pessoas refletem sobre a possibilidade de equiparação que se lhes apresenta. Daí se pode enfim compreender o inteligente conceito de felicidade de Thomas Hobbes ( $D e$ homine, 11, 15), que a definiu como ad fines semper ulteriores minime impedita progressio, um progresso o menos impedido possível à consecução de fins cada vez mais distantes.

À constituição e essência do ser humano pertence uma sobrecarga de impulsos que estão por trás daquelas forças, e que já têm um alcance excessivo, que são seus sentidos, seu pensamento, seu desejo. Vale dizer, o potencial desses impulsos ultrapassa em muito as necessidades vitais básicas necessárias ao longo de uma vida. O indivíduo quer a satisfação de pulsões, ampliação de experiências e multiplicação de estímulos para além todo ponto zero das condições habituais da vida. Ele é empurrado, digamos assim, para um "mais além", para uma situação qualquer de superabundância, seja ela de tipo material, espiritual ou intelectual. Superabundância (Überfluss) é uma palavra duvidosa, que se aproxima da de "supérfluo" (überflussig). O quadro acima descrito está prenhe de conflitos e nos torna dependentes de chances e acasos forçados, mas também de intervenções perturbadoras, pois o aumento de nosso bem-estar depende de condições que não estão sob nosso controle. Aliás bem pode ser que a mecanização e a coletivização da vida, com sua distribuição de oportunidades da ideia de felicidade, tenham uma importância cada vez menor.

Mas com isso não esgotamos tudo o que há de obscuro na questão. Como sobrecarga psíquica adicional há ainda uma lei que se pode formular desta maneira: somente o adquirir está envolto em prazer, não o possuir. Vimos acima como esta lei nos leva, no melhor dos casos, a situações de neutralização do prazer, quando não de desinteresse em relação às ocupações do dia a dia em nossas esferas cotidianas; ou então à ampliação das vivências ou da capacidade de ação. Diante dos estados mais habituais, estes são incomuns e é justamente a eles que se relacionam as sensações de felicidade. Daí o fascínio irresistível de impressões, experiências e encontros extracotidianos a que corresponde uma curiosidade íntima, até mesmo uma pulsão intelectual pelo improvável e pela novidade. Tudo o que por sua aparência exterior ou seu estado interior ultrapassa o patamar mediano atrai nossa atenção e dedicação, sendo esta a razão pela qual os homens pré-históricos já recolhiam e guardavam pedras cintilantes e minerais coloridos. E se hoje nos surpreendemos com a disseminação das drogas não devemos esquecer o fato de que nunca existiu uma sociedade tão primitiva que não tenha identificado em seu meio ambiente toda sorte de substâncias tóxicas e drogas - tabaco ou álcool, mescalina, ópio ou o que quer que fosse - a fim de transformar radicalmente o seu espaço de vivências de tempos em tempos. Subsiste também uma ânsia por auto-elevação nesses estados de ebriedade, talvez no sentido de uma aceleração dos efeitos, tal como o viciado 
que injeta sua droga em si mesmo ou o jogador apaixonado que abandona a roleta por considerá-la demasiado lenta e que passa então a procurar um jogo mais rápido.

Já afirmei que somente o adquirir está envolto em prazer, não o possuir. Alguns de vocês colecionam alguma coisa e assim conhecem a excitação que envolve a obtenção uma peça rara. Mas depois de certo tempo diminui a sensação de júbilo desta descoberta, mesmo quando o seu valor se eleva e no horizonte de expectativa surge algo ainda mais raro e que passa então a ser única coisa desejável.

Mas se apenas a aquisição envolve prazer, então a posse se torna algo entediante. O que aliás pode valer para descobertas intelectuais e mesmo as mais elevadas dentre elas. Se a isso acrescentamos outra constatação, de que para além de todo ponto-zero somos empurrados para a região do ordinário, então chega-se a conclusões que não são muito claras. É como se, por nossa própria constituição, estivéssemos obrigados a ficar entre alternativas ruins: o ordinário, isto é, o tédio, que segundo Schopenhauer finalmente desenharia o verdadeiro desespero sobre os rostos, sendo necessário tomar medidas públicas contra ele. Ou então a busca por alguma coisa que, no melhor dos casos, se revela insossa tão logo é obtida ou que se mantém completamente fechada para nós. Eu não vejo nenhuma outra força capaz de nos resguardar de tal princípio que não a vitalidade da juventude.

Tenho de me deter ainda um pouco mais nessas observações inquietantes para poder introduzir o tema da nostalgia. Apoio-me agora nos enunciados de um dos mais notáveis pensadores modernos, Sigmund Freud, que em seu escrito de 1930 O mal-estar na civilização perguntou sobre o que os seres humanos querem da vida. Sua resposta: "Eles buscam a felicidade, querem se tornar e permanecer felizes". E prosseguiu: "Este programa é absolutamente inexequível, todo o arranjo do universo o contraria; podemos dizer que a intenção de que o ser humano seja 'feliz' não se acha no plano da 'criação'"' (FREUD 2011, p. 19).

Baseado em sua teoria ele justificou isso, primeiro, com a negação das pulsões que a civilização exige de nós e nos impõe, e, segundo, com a hostilidade de princípio, originária, que os seres humanos mantêm entre si, a conhecida pulsão de agressão. Não me ocuparei com esta última aqui, embora ela possa ter algo a dizer. Mas justificar o mal-estar com a negação das pulsões deixou de ser algo convincente desde que as pulsões sexuais e de agressão passaram a obter ampla liberdade de ação e os seres humanos não se tornaram mais felizes - a não ser que eles sejam adeptos da política do prazer de Marcuse, que advoga a felicidade futura na absoluta ausência de impedimentos. Na verdade, começamos a nutrir a suspeita de que concomitantemente ao aumento da oferta por felicidade também se vende uma crescente expectativa de decepções. Difunde-se algo como um porre por excesso de oferta.

Poder-se-ia, porém, perguntar: e quanto aos prazeres intelectuais? O que se denomina intelecto tem diversas características e também pode ser visto enquanto uma forma de organização do afã pelo novo e pelo que ainda não foi posto à prova. Nesse ponto as inovações dos artistas ou as descobertas dos 
cientistas poderiam ser descritas como surpresas intelectuais encontradas após uma longa busca. Quando se é jovem, quando faz se descobertas ou se descobre um território ainda virgem, o intelecto é capaz de proporcionar sentimentos de felicidade; mas quanto à posse estou convencido de que a maioria dos autores não leem com prazer seus escritos mais antigos; provavelmente acontece o mesmo com os artistas, sobretudo quando são obrigados a reiteradamente copiar o próprio estilo depois deste se tornar um artigo de marca. Também aqui parece que o que produz felicidade é apenas o adquirir e não o possuir.

Sei inclusive que no processo de produção pode se manifestar um tipo de aversão à posse da própria produção intelectual, e que, portanto, trabalhamos desde o início imersos numa nuvem de tédio. A pressa seca ou a brevidade, tantas vezes observadas justamente no estilo daqueles que atingiram a maturidade, parecem confirmá-lo. A pessoa fica entediada com suas próprias criações antes mesmo delas serem concluídas. Madame de Staël ou quem sabe o seu oráculo August Wilhelm Schlegel reconheciam algo assim em Goethe, sobre o qual se afirma em De l'Allemagne que ele s'approche des plus grands effets pour les délaisser tout à coup, comme s'il ne valait pas la peine de les produire - que ele aproxima-se dos maiores efeitos para abandoná-los repentinamente, como se se não valesse a pena produzi-los (DE STAËL 2016, p. 389). Não posso me esquivar aqui de mais uma reflexão embora ela não tenha a ver com meu tema, a de que nas palavras acima encontramos uma explicação para o obscuro conceito de ironia romântica. Caso imaginemos a inteligente observação da Sra. de Staël 146 aplicada também aos artistas e poetas, o que se obtém então é esse pairar do intelecto sobre suas próprias realizações, e por sobre as quais ele parece nos sorrir lá das alturas. A obra de arte e a maior das descobertas científicas já contém, em forma embrionária, algo como uma paródia de si mesmas. Foi assim que um extraordinário artista como Josef Conrad classificou a si mesmo: como uma espécie de inspirado embusteiro.

É mais que passada a hora, porém, de explicar por que estas análises foram antepostas ao tema da nostalgia. Já vimos que a busca pela felicidade é uma conta que não fecha. Às vezes a felicidade ao consumir gera, em nós mesmos, o inimigo do consumo que defende sua liberdade. A felicidade associada a certas experiências, por outro lado, só pode surgir de maneira casual e instável; quando é procurada de forma metódica, por exemplo no caso do viciado, então ela se quebra sobre si mesma como uma onda. A felicidade da produtividade intelectual, e que mesmo assim só é acessível a poucas pessoas, se revela frágil porque mostra uma outra face, geralmente omitida, de tédio ou de esgotamento. No longo prazo e em geral, o trabalho intelectual de segunda mão satisfaz apenas aos pedantes. Que possibilidades restam então?

Quando a realidade não confirma ou até mesmo contradiz nosso incansável impulso por um "mais além", ainda assim resta uma última alternativa - evadir no tempo e povoar a própria fantasia com imagens de felicidade. Quando este processo se volta para o futuro, surgem as utopias, que como que reificam magníficas situações vindouras para nós. A utopia haure seus elementos constitutivos somente a partir do presente, mas é de forma seletiva que ela 
edifica um belo edifício, ainda que destituído de fundamentos. Nunca obtemos uma resposta à pergunta sobre o que faremos para escapar ao tédio, caso a utopia seja realizada. Quando, porém, a fantasia de felicidade brilha retrospectivamente é que chegamos, enfim, à nostalgia.

Nostalgia significa saudades de casa (Heimweh), e hoje muitas pessoas pensam como se ainda vivessem em tempos passados, devotando-Ihes um sentimento luminoso. Colecionam-se os restos de épocas antigas, até mesmo o cotidiano em quantidades crescentes, a mobília doméstica, e atualmente estes restos atraem inclusive os mais jovens. Quando se iniciou esse movimento espiritual que hoje se espalha ao infinito e abarca sempre novas relíquias?

Foi o escritor norte-americano William Faulkner, nascido em 1897 e originado numa família empobrecida da aristocracia agrária do sul, quem nos anos 1930 resgatou em grandes épicos, apartados do entorno plebeu, a vitalidade selvagem, a nobreza e a glória, a degeneração e a crueldade dos estados do sul dos Estados Unidos. Ele direcionou então sua fantasia para a época da gloriosa decadência dos estados confederados, por volta de 1865 . Ele próprio não a viveu, mas tinha sido a época de seus pais. Nascida em 1900 em Atlanta, Georgia, Margaret Mitchell escrevia naquele mesmo momento seu livro mundialmente aclamado $E$ o vento levou, e cuja versão cinematográfica foi ainda mais bem-sucedida. Ela recolheu e estudou por anos os menores resquícios, documentos e descrições dos estados do sul, inclusive os costumes linguísticos, a etiqueta, as modas. Estes romances não são históricos no sentido de Walter Scott ou Felix Dahn; eles nos apresentam um mundo rústico, imenso e exótico, destruído por forças que lhe são externas e vítima de um transcorrer absurdo da história; destinos grandiosos que sobreviveram apenas por meio da literatura, como os burgúndios na Canção dos Nibelungos. A felicidade evadida é a possibilidade de viver de uma forma que nos teria purificado e elevado.

Nesse contexto deve-se ainda acrescentar a Forsyte Saga de Galsworthy, obra que apareceu em cinco volumes entre 1906 e 1921. Causa admiração o gênio de sua fina audição, por meio da qual ele ouviu os cupins nas vigas muito antes do advento da guerra. Aqui já soava a grande decadência. Nunca mencionada, ela é pressentida com honra e não com vergonha. Apareceram então os Buddenbrooks, em 1901, com o tema similar do declínio de uma família da alta burguesia. Mas há uma diferença fundamental se o pano de fundo é Lübeck ou Londres. O encanto nostálgico destes romances épicos assenta no fato de que seus personagens são por assim dizer vestidos com um prazo de validade. Eles vêm a um mundo dotados do olhar da providência e no entanto são cegos; um mundo que termina para todos, mesmo os mais dilacerados individualistas, com uma moral de sindicato - disso sabemos nós, não eles.

Muito mais direta é a influência de Fontane através de seus romances sobre os meios berlinenses e o distrito de Märkisch de seu tempo. Foram publicados em revistas perfeitamente burguesas como Gartenlaube, Über Land und Meer ou Deutsche Rundschau. Fontane não esperava obter fama póstuma através destes romances que hoje tanto fascinam, nem das cerca de 3.000 páginas de sua história local da Prússia, as Peregrinações pelo Margraviato de 
Brandenburgo, e que agora aparecem em edição de baixo custo, mas sim por meio de suas baladas, que hoje em dia ninguém conhece mais. Ao lado desses grandes autores, os mediadores da nostalgia, há o círculo dos pequenos, e, devo admitir, indiferente à acusação de kitsch, que considero magníficas as novas e grandes versões cinematográficas em cores dos romances de Eugenie Marlitt. Há bem pouca literatura moderna hoje em dia à qual não se possa fazer a acusação de kitsch, e com isso quero dizer o demasiado acessível e a fragmentação dos pensamentos e sentimentos.

Depois destes exemplos por hora tomados apenas à literatura, podese finalmente chegar a algumas conclusões. Nossa nostalgia sempre se prende a um espaço de tempo pregresso que alcança até meados do século anterior. Volta-se para a época de Bismarck ou dos Imperadores Guilherme e Franz Josef. Para além do ano de 1850 não há nostalgia alguma, o período Biedermeier não gera nostalgia e a época do classicismo rococó muito menos. ${ }^{1}$ Por conseguinte, a época nostálgica se estende aproximadamente de 1850 a 1914, época do inabalado prestígio e dominação da Europa. Ela não é apresentada, como supõe um tolo slogan, como um "mundinho em ordem", pelo contrário. Acontecem ali todos os tipos de crimes e aviltamentos, mas há também decência e fidelidade, o sacrifício cego tanto quanto o consciente. Lê-se no Ptolemäer de 1949 o alto lamento nostálgico na consciência do fim da civilização ocidental: "o primeiro gesto sustentou o falcão no pulso, o último segurou o pardal na mão" (BENN 1949, p. 11).

148 Tenho agora de dar continuidade à minha interpretação. Há uma consequência repugnante do atual estado de coisas, uma repugnância que nos abre para o efeito magnético do passado. Os choques que nos chegam pela mídia, o agitado ritmo temporal, a excitante política diária, a coerção infinita das compras e a falta de credibilidade de solenes declarações públicas com seus subterfúgios fugazes - isso tudo se desdobra numa energia repugnante, e então percebemos que ocupar-se com o período anterior à guerra, mais do que um valor de relaxamento, tem um valor de orientação.

Dificilmente, porém, serei contestado em minha opinião de que nosso presente carece de forças que o sustentem. Parece que o nó a que tudo estava atado se desfez, e agora os fios nos escapam entre os dedos. Nenhuma coisa, nenhum valor que não seja contestado. Nas camadas inferiores treme-se por causa do desemprego, nas médias por causa de clientes insolventes ou escassez de encomendas, nas superiores por causa de sequestros e terroristas. Mal se consegue pensar numa questão relevante, a começar pela educação infantil, o sistema escolar, o serviço militar, até a legitimidade da propriedade ou do poder decisório existente, que não seja controversa, e, contudo, é gasta a opinião de que a liberdade assentaria justamente nisso. Diálogos entre pessoas ao estilo dos de Ionescu, em que cada qual perde exatamente aquilo que procura no contato com os outros, não podem mais ser vistos como um exagero. Talvez 
possamos compreender melhor essa desorientação espiritual quando nos damos conta que as pessoas de trinta anos ou mais jovens nunca viveram situações extremas, nenhum perigo de morte, nenhuma fuga, fome, vingança de conceitos, humilhações. Elas se desoneraram de forma totalmente voluntária.

Na era nostálgica, entretanto, encontra-se possibilidade de prospecção, posições consensuais, pessoas que se posicionaram e se responsabilizaram, encontram-se hostilidades políticas, mas sob condições que nos permitem resolvê-las; havia certamente baixeza e malevolência, mas também a postura dos grandes líderes, como quando Bismarck em 1862 ou Sir Edward Grey, em 1914, jogaram às claras as cartas do grande jogo.

Tudo isso, tomado em conjunto, já seria motivo suficiente para um movimento retrospectivo da imaginação em direção ao passado, e que por toda parte revela relações poéticas, mensuráveis e estáveis. A agitação e a angustiada diligência do presente não existiam ali, e pode-se sustentar a afirmação de que o ser humano tem o direito de buscar um mundo mais humano, ainda que somente na imaginação.

Mas eu vejo aí uma outra dimensão. Não se deve esquecer que o retorno nostálgico no sul dos Estados Unidos, na Inglaterra e na Alemanha é sustentado pelos netos de superpotências destruídas. Com isso não queremos pensar na resistência sentimental a uma história que segue inexoravelmente, mas na tristeza espiritual daqueles que percebem quão penetrante e requintadamente age o desenraizamento. Naturalmente, aqui se evidencia um termo como "reacionário", e eu me divirto ao ver o apelo do político italiano Amintore Fanfani, que inclui a luta contra a nostalgia e as manifestações de influência fascista entre os mais importantes problemas italianos (Die Welt, 21/05/1975). Ora, não sei pelo que anseia a população da Itália, mas o viajante se surpreende ali com as centenas de pichações que expõem as condições atuais a partir de todas as posições políticas possíveis.

Posso enfim recorrer a uma pessoa bastante conhecida, Bertrand Russel, em apoio a minhas opiniões. Por negar-se ao serviço militar ele foi preso durante a Primeira Guerra mundial. Era um pacifista, membro da ala esquerda do Partido Trabalhista, agraciado com o prêmio Nobel. No segundo volume de sua autobiografia, publicada em 1973 pela editora Suhrkamp, e escrita em idade avançada, Russel escreveu literalmente: "Sinto falta do sustentáculo da continuidade histórica e do pertencimento a uma grande nação" (RUSSEL 1973, p. 238). Difícil caracterizá-lo com um fascista.

Caso essa interpretação histórico-política da nostalgia esteja correta, compreende-se então por que não encontramos nostalgia na França. Este país ainda é soberano, não foi derrotado, tem a coesão política das grandes nações e, apesar de todos os conflitos internos, não se curva desde a época dos gauleses. Também na Rússia ou na Espanha não há nostalgia. Ambos foram capazes de preservar sua substância e não estão obrigados a procurar por sua identidade.

Nenhum dos personagens de Fontane faz isso. Nele as pessoas vivem juntas, mas não em associações. Não na assim chamada parceria, mas como cada um é, de verdade. Não como meros suportes de ideias, mas sem serem 
destituídos de conviç̧ões. O personagem é um comerciante do interior ou oficial ou a filha de uma família burguesa, ele é um alemão em um mundo que se mantém de pé.

E agora tenho ainda de defender o esquema do nacionalismo. No século XVIII os alemães das camadas sociais ilustres eram afrancesados, eles perseguiram então sua autocolonização de forma tão obstinada como nos dias de hoje, em que estão americanizados. A respeito disse há pouco Rudolf Augstein (Der Spiegel n. 10, 1975), que certamente deve ser versado nisso, que a República Federal da Alemanha segue mancando cerca de cinco anos atrás dos Estados Unidos, e então teriam começado as cópias. A nostalgia pretende ir além desta autocolonização, de volta a uma época em que, por muito tempo, se pôde falar em alemão.

Alguém poderia então dizer: isso é uma superinterpretação, você faz de seu tema a voz infeliz de nações infelizes, que tiveram de ceder ou mesmo desaparecer completamente, mas tais redescobertas do passado ocorreram inúmeras vezes. Você não sabia que as pessoas da época da Renascença estavam completamente seduzidas pela Antiguidade, e que por mais uma vez o Romantismo desenterrou a Idade Média? Gostaria, enfim, de tratar disso rapidamente, começando por algumas poucas palavras sobre a Renascença.

A redescoberta da Antiguidade, que nunca foi inteiramente esquecida, mas que por assim dizer foi posta na ordem do dia, era uma coisa da elite, que dizia respeito à nobreza, aos filólogos e poetas, aos artistas e mecenas 150 endinheirados; a maior parte do povo, mesmo em Florença, manteve-se alheia. Apenas no espaço cultural das classes superiores é que se pôde manter a enorme tensão entre Antiguidade e cristianismo, e não sem crassos desvios pagãos como em Signorelli e Botticelli. Quando então começou a surgir um estilo inteiramente novo, em cenas com um pouco de luminosidade e alvorecer destituídos de sombras, ali se manifestou a Reforma, um movimento fanático deflagrado entre as classes inferiores que rapidamente se expandiu para a Itália e em breve levou à Contrarreforma, este retorno a um cristianismo de tipo mais vigoroso. O que se acessava e se retinha da Antiguidade eram três coisas: em primeiro lugar os motivos artísticos empregados em todas as artes, em segundo lugar uma concepção de política autônoma, no rastro de Maquiavel, e finalmente, impossível esquecer, uma noção do fascínio suscitado pelas civilizações aristocráticas e destituídas de sacerdotes. Tudo isso permaneceu mero episódio, a menos que se veja ali uma forma prévia do Iluminismo - o que até poderia ser defendido -, mas este motivo não teve penetração nem mesmo entre os mestres; e até mesmo um octogenário Michelangelo reincorporou elementos góticos (Pietà Rondanini).

No que toca ao Romantismo, com sua inclinação pela Idade Média, no geral trata-se de um cenário estranhamente difuso, instável e sem direção. Por toda parte tem-se a impressão de improviso. Em meio a pihas de produção literária nos perdemos e somos enredados. Porém algumas linhas se destacam, se se permite a simplificação. 
Existe uma estética de Hegel, postumamente publicada. Ele empregou o termo Romantismo para o mundo que se seguiu à Antiguidade, o mundo cristão, portanto, e que ele via se estendendo até o seu próprio eu. Hegel se referiu à interioridade ou à intelectualidade como a essência deste Romantismo, e às vezes falava também da ilimitada subjetividade do ser humano. Muitas vezes não fica muito claro se está falando da cavalaria e do gótico ou da poesia e da pintura de seu tempo, repletas que estavam de elementos daquelas épocas. Já Goethe, em 1774, na sua primeira versão do Fausto, desloca o cenário para um quarto gótico. O gótico era percebido então, também por Goethe, como manifestamente alemão porque sua origem francesa era ignorada.

Por volta de $1820 \mathrm{Hegel}$ parecia trabalhar com o pensamento de Schlegel, que em suas preleções berlinenses de 1801-1804 desenhou uma imagem elevada da Idade Média e elogiou sua suposta unicidade e universalidade para desacreditar o Iluminismo do século XVIII. Schlegel foi, por conseguinte, o autor da confrontação entre o mundo antigo-clássico e o romântico-medieval, tendo este sido considerado o mundo moderno e ainda válido.

Assim não pôde surgir nostalgia alguma, mas sim uma frente de ataque romântica de proporção verdadeiramente universal que se voltou contra o Iluminismo de origem franco-britânica. Este foi combatido inicialmente como alienação da germanidade, e contra ele os românticos mobilizaram a investigação dos primórdios de nossa história, literatura e linguagem; depois polemizaram contra a face elitista do Iluminismo, em que exerciam liderança homens distintos como Montesquieu, Locke ou D'Alambert. Por oposição, promoveu-se o popular, o conto folclórico e as sagas. E então, mais uma vez, uma cristandade artificial levantou-se contra o Iluminismo. Para todos estes ataques encontrou-se munição na Idade Média, na mais antiga língua, nas tradições populares e no cristianismo.

Deste modo, tenho a impressão que a ideologia romântica, por Hegel filosoficamente fundamentada, configura uma defesa geral contra as influências do Iluminismo. Muito tempo antes da unificação alemã buscou-se conscientemente realizar ali uma unidade espiritual na rejeição ao Iluminismo, e o movimento como um todo era, em última instância, tão político quanto sua elaboração confusa e arbitrária o permitiu. Nas suas Preleções sobre literatura e sobre arte dramática, publicadas em 1809, Schlegel afirma: "Na região espiritual da reflexão e da literatura, inacessíveis ao poder político, os alemães tantas vezes divididos pressentem sua unidade" (SCHLEGEL 1923, p. cxii). É esta, certamente, a célula embrionária do topos dos alemães como o povo dos poetas e pensadores.

Diga-se: se ao menos ainda o fôssemos. A saudade nostálgica tem um caráter próprio, como mostrei, não devendo ser comparada com a Renascença ou o Romantismo, e nenhum augúrio de grande política é nela tematizado. É a voz de nações infelizes, que se colocaram à margem da grande História. Na pequena, oxalá um dia, elas hão de encontrar o seu papel. 


\section{Referências bibliográficas}

BENN, Gottfried. Die Ptolemäer. Wiesbaden: Limes, 1949.

BRIEFS, Götz. Das gewerbliche Proletariat. In: Grundriss der Sozialökonomik. Tübingen: J. C. B. Mohr, 1925.

DE STAËL, Madame. Da Alemanha. São Paulo: Ed. Unesp, 2016.

FREUD, Sigmund. O mal-estar na civilização. São Paulo: Cia. das Letras, 2011.

HOFFSTÄTTER, Peter R. Individuum und Gesellschaft. Frankfurt am Main: Ullstein, 1972.

RUSSEL, Bertrand. Autobiographie II (1914-1944). Frankfurt am Main: Suhrkamp, 1973.

SCHLEGEL, August Wilhelm. Kritische Ausgabe. Bonn; Leipzig: Schroeder, 1923. v. I.

TALMON, Jacob L. Die Ursprünge der totalitären Demokratie. Köln: Westdeutscher Verlag, 1961. 


\title{
Mal-estar na nostalgia*
}

\author{
Nostalgia and its discontents
}

Svetlana Boym**

O século $X X$ se iniciou com utopia e terminou em nostalgia. A crença otimista no futuro tornou-se obsoleta, enquanto a nostalgia, para o bem ou para o mal, nunca saiu de moda, permanecendo estranhamente contemporânea. A palavra nostalgia advém de duas raízes gregas, nostos que significa "voltar à casa" e algia, anseio. Eu a definiria como um desejo por um lar que não existe mais ou nunca existiu. Nostalgia é um sentimento de perda e deslocamento, mas é também uma fascinação com a própria fantasia. O amor nostálgico só pode sobreviver em um relacionamento à distância. A exposição dupla ou a sobreposição de duas imagens - da terra natal e da estrangeira, do passado e do presente, do sonho e da vida cotidiana - é uma boa imagem cinematográfica da nostalgia. No momento em que tentamos encaixá-las em uma única imagem, ela rompe o quadro ou queima a película.

A palavra nostalgia, a despeito de suas raízes gregas, não teve origem na Grécia antiga. Nostalgia é apenas falsamente grega, ou nostalgicamente grega. A palavra foi forjada pelo ambicioso erudito suíço Johanes Hofer em sua tese de medicina de 1688 (Hofer também sugeria as alternativas nosomania ou philopatridomania para descrever os mesmos sintomas; felizmente, estas não lograram entrar na linguagem comum). Contrariamente à nossa intuição, nostalgia veio da medicina, não da poesia ou da política. Não nos ocorreria pedir uma receita médica para nostalgia. Ainda no século XVII, a nostalgia era considerada uma doença curável, semelhante a uma severa gripe comum. Médicos suíços acreditavam que ópio, sanguessugas e uma viagem aos Alpes suíços curariam os sintomas nostálgicos.

Entre as primeiras vítimas da doença recentemente diagnosticada encontravam-se vários desterrados do século XVII: jovens amantes da liberdade da República de Berna estudando na Basileia, empregados domésticos e ajudantes trabalhando na França e na Alemanha, e soldados suíços lutando no estrangeiro. A epidemia de nostalgia foi acompanhada por uma epidemia ainda

\footnotetext{
* Este ensaio é uma adaptação do meu livro The Future of Nostalgia (2001), o qual inclui uma discussão mais aprofundada deste tópico. (O ensaio foi publicado originalmente no The Hedgehog Review, v. 9, n. 2, sum. 2007; os tradutores Marcelo Santos de Abreu e André de Lemos Freixo agradecem ao professor David Damrosch, executor literário de Svetlana Boym, pela autorização para publicação desta tradução. NTs).

** Svetlana Boym (1966-2015) foi Professora Curt Hugo Reisinger de Linguagens e Literaturas Eslavas e de Literatura Comparada na Universidade de Harvard. Seus principais livros acadêmicos são Death in Quotation Marks: Cultural Myths of the Modern Poet (1991), Common Places: Mythologies of Everyday Life in Russia (1994), The Future of Nostalgia (2001) e Kosmos: Remembrances of the Future (com Adam Bartos, 2001). Escreveu também um romance, Ninochka (2003). Ela também escreveu muitos artigos sobre criatividade e exílio, poesia e política, cultura contemporânea, utopia e kitsch, e memória e modernidade.
} 
mais perigosa de "nostalgia fingida", particularmente entre soldados cansados de servir no exterior. ${ }^{1}$

A nostalgia que me interessa aqui não é meramente uma doença individual, mas sim um sintoma de nossa época, uma emoção histórica. Portanto, farei três observações cruciais. Primeiro, a nostalgia não é anti-moderna; ela não é necessariamente oposta à modernidade, mas sim contemporânea a ela. Nostalgia e progresso são como Jekyll e Hyde: pares e imagens espelhadas um do outro. A nostalgia não é apenas uma expressão de saudade local, mas resultado de uma nova compreensão do tempo e do espaço que faz a divisão entre local e universal possível.

Segundo, nostalgia parece ser a saudade de um lugar, mas é na realidade um anseio por um tempo diferente - o tempo de nossa infância, dos ritmos mais lentos de nossos sonhos. Em um sentido ainda mais amplo, a nostalgia é uma revolta contra a ideia moderna de tempo, o tempo da história e do progresso. Os desejos nostálgicos de transformar a história em uma mitologia individual ou coletiva, de revistar os tempos como espaço, recusando renderse à irreversibilidade do tempo que atormenta a condição humana. Assim, o passado da nostalgia, parafraseando William Faulkner, não é sequer passado. Pode ser apenas um tempo melhor, ou um tempo mais lento - tempo fora do tempo, não sobrecarregado por agendas repletas de compromissos.

Terceiro, a nostalgia, a meu ver, nem sempre é retrospectiva; pode ser igualmente prospectiva. As fantasias sobre o passado, determinadas pelas necessidades do presente, têm um impacto direto nas realidades do futuro. A consideração do futuro nos faz assumir a responsabilidade por nossas fábulas nostálgicas. Diferentemente da melancolia, que se restringe aos planos da consciência individual, a nostalgia trata das relações entre a biografia individual e a biografia de grupos ou nações, entre as memórias pessoal e coletiva. Se as utopias futuristas podem estar fora de moda, a nostalgia tem uma dimensão utópica - que apenas não é mais dirigida ao futuro. Algumas vezes, nem sequer é diretamente dirigida ao passado, mas sim tangencialmente. O nostálgico sente-se sufocado dentro dos limites convencionais de tempo e espaço.

Na verdade, há uma tradição da reflexão crítica sobre a condição moderna que incorpora a nostalgia. Ela pode ser chamada off-moderna. O prefixo off ${ }^{2}$ confunde

\footnotetext{
${ }^{1}$ Hofer (1934, p. 381) acreditava que seria possível "definir a partir da força de uma forte nostalgia o triste clima que se origina do desejo de retornar a sua terra natal". Hofer reconhecia que "helvéticos brilhantes" desenvolveram um termo vernáculo para "a aflição pela perda dos encantos da terra natal", das Heimweh, e os aflitos gauleses (os franceses) usavam o termo la Maladie du Pays (HOFER 1934, p. 380). Mas Hofer foi o primeiro a apresentar detalhada discussão científica para a doença. Para uma história da nostalgia, ver Jean Starobinski (1966, p. 81-103); Fritz Ernst, Vom Heimweh (1949); e George Rosen (1975, p. 28-51). Para abordagens psicológicas e psicanalíticas da nostalgia, ver James Phillips (1985, p. 64-75); Willis H. McCann (1943, p. 97-104); Roderick Peters (1985, p. 135-48). Para um estudo muito interessante da sociologia da nostalgia que a examina enquanto "emoção social" e sugere o exame de três ordens ascendentes de nostalgia, ver Fred Davis (1979).

2 Uma tradução possível para off-modern seria extra-moderno; mas o prefixo latino não tem o mesmo sentido do que o advérbio off tem no inglês; o prefixo extra pode designar algo como alternativo ou fora de um curso determinado, isto é, alternativo a uma visão normativa da modernidade. Off porém captura melhor a possibilidade de paralelismo, de simultaneidade de movimentos que são modernos, mas não podem ser reduzidos a uma forma do ser moderno - aquela que normalmente se confunde com a modernidade europeia ocidental sobretudo. Decidimos acompanhar a solução adotada pelo tradutor espanhol. Sobre a ideia de modernidades alternativas, que se adequa nesse trecho ao que a autora diz, ver Eisenstadt (2000); e Gaonkar (2001). Ainda sobre a ideia de off-modernism pode-se consultar o manifesto da autora respeito da condição
} 
nosso sentido de direção. Faz-nos explorar atalhos e becos em vez da estrada reta do progresso; permite-nos tomar um desvio na narrativa determinista da história. O off-modernismo apresenta simultaneamente uma crítica da fascinação moderna com a novidade e a não menos moderna reinvenção da tradição. $\mathrm{Na}$ tradição off-moderna, reflexão e saudade, estranhamento e simpatia, andam juntas. Além disso, para alguns dos off-modernismos do século XX que vieram de tradições consideradas marginas ou provincianas com relação às tendências culturais dominantes (do Leste Europeu à América Latina), assim como para muitos povos desterrados em todo o mundo, repensar criativamente a nostalgia não foi apenas um exercício artístico, mas uma estratégia de sobrevivência, uma forma de tornar razoável a impossibilidade de um retorno ao lar.

Os historiadores frequentemente consideram nostalgia uma palavra negativa ou, na melhor das hipóteses, um simpático insulto. "A nostalgia está para a saudade como o kitsch está para a arte", escreveu Charles Maier (MAIER 1999, p. 273). Frequentemente, a palavra é usada de forma desdenhosa. "A nostalgia... é essencialmente história sem culpa. O patrimônio é algo que nos enche de orgulho em vez de vergonha", disse Michael Kammen (KAMMEN 1991, p. 688). Nessa compreensão, a nostalgia é vista como uma abdicação da responsabilidade pessoal, um retorno ao lar livre de culpa, uma falha ética e estética. A nostalgia produz visões subjetivas da imaginação atormentada que tende a colonizar os domínios da política, da história e da percepção cotidiana.

A nostalgia moderna é paradoxal no sentido de que a universalidade de sua saudade pode aumentar nossa empatia pelos seres humanos, e ainda assim, quando tentamos reparar essa saudade com um pertencimento particular - ou a apreensão da perda com a redescoberta da identidade e, particularmente, de uma comunidade nacional e pátria pura e única - nós frequentemente nos distanciamos de outros e encerramos o entendimento mútuo. Algia (saudade) é o que partilhamos, e nostos (ou a volta para casa) é o que nos divide. A promessa de reconstruir o lar ideal repousa no cerne de muitas ideologias poderosas hoje em dia, tentando-nos a trocar o pensamento crítico por laços emocionais. O perigo da nostalgia é que ela tende a confundir o verdadeiro lar com aquele imaginado. Em casos extremos ela pode criar uma terra natal fantasma, em nome da qual alguém está pronto a morrer ou a matar. A nostalgia irrefletida pode gerar monstros. Contudo, o sentimento propriamente, a dor do deslocamento e da irreversibilidade temporal, está no cerne mesmo da condição moderna. Ao reclamar uma pátria pura e limpa, a política da nostalgia comumente produz um híbrido "glocal" de capitalismo e fundamentalismo religioso ou de estado corporativo e patriotismo eurásico. A mistura de nostalgia e política pode ser explosiva.

O sedutor objeto da nostalgia é notoriamente elusivo. O sentimento ambivalente permeia a cultura popular na qual os avanços tecnológicos e efeitos especiais são frequentemente usados para recriar visões do passado, 
do naufrágio do Titanic aos gladiadores morrendo na arena, passando pelos dinossauros extintos. Enquanto muitos pensadores do século XIX acreditavam que o progresso e o esclarecimento curariam a nostalgia, eles ao contrário, a exacerbaram. A tecnologia, que prometera superar o deslocamento e a distância modernos e fornecer a miraculosa prótese para as agruras nostálgicas, tornouse mais rápida que o desejo nostálgico. Mais exatamente, tecnologia e nostalgia tornaram-se codependentes: a nova tecnologia e a propaganda estimularam a nostalgia artificial - pelas coisas que nunca pensávamos perdidas - e a nostalgia antecipatória - pelo presente que foge na velocidade de um click. De forma semelhante, a globalização encoraja fortes laços locais. Em contrapartida à nossa fascinação com o ciberespaço e pela aldeia global virtual, há uma epidemia global de nostalgia, e um anseio efetivo por uma comunidade com uma memória coletiva, um desejo de continuidade em um mundo fragmentado. A nostalgia reaparece inevitavelmente como um mecanismo de defesa em um tempo de mudanças históricas drásticas e ritmos acelerados de vida. Mas esse mecanismo de defesa tem seus próprios efeitos colaterais.

Surtos de nostalgia se seguem frequentemente às revoluções; a Revolução Francesa de 1789, a Revolução Russa e as revoluções de "Veludo" no Leste Europeu foram acompanhadas por manifestações políticas e culturais de saudade. Na França, não foi apenas o Antigo Regime que produziu a revolução, mas, em algum sentido, a revolução que produziu o Antigo Regime, conferindoIhe uma forma, um encerramento e uma aura dourada. De forma semelhante, a 156 época revolucionária da Perestroica e o fim da União Soviética produziram uma imagem das últimas décadas do regime soviético como um tempo de estagnação ou, ao contrário, como uma Idade de Ouro soviética de estabilidade, força e normalidade - a visão que prevaleceu na Rússia por volta do ano 2000. Porém, a nostalgia que analiso aqui nem sempre é pelo Antigo Regime, pela estabilidade da superpotência ou por um império derrubado, mas também pelos sonhos não realizados do passado e visões do futuro que se tornaram obsoletas. Uma história da nostalgia poderia nos permitir rever a história moderna não buscando apenas a novidade e o progresso tecnológico, mas também por possibilidades não realizadas, viradas imprevistas e encruzilhadas.

Dinheiro e cultura popular são as moedas mais comuns do globalismo exportado para todo mundo. A nostalgia também é uma característica da cultura global, mas ela requer uma moeda diferente. Afinal, as palavras chaves a definir o globalismo - progresso, modernidade e realidade virtual - foram inventadas por poetas e filósofos: "progresso" foi cunhada por Immanuel Kant; o substantivo "modernidade" é uma criação de Charles Baudelaire; e "realidade virtual" foi primeiramente imaginada por Henri Bergson, não por Bill Gates. Na definição de Bergson, no entanto, "realidade virtual" se referia aos planos de consciência, dimensões potenciais do tempo e da criatividade que são própria e unicamente humanas. Quando os médicos do século XVIII falhavam em revelar o locus da nostalgia, eles recomendavam buscar a ajuda de poetas e filósofos. A nostalgia se expressa por enigmas e charadas, e deve-se enfrentá-las a fim de não se tornar sua próxima vítima ou o próximo algoz. 
O estudo da nostalgia não pertence a nenhuma disciplina particular; ela frustra psicólogos, sociólogos, teóricos literários e filósofos - até os analistas de sistemas que pensavam ter se livrado dela inteiramente, até que também se refugiaram em suas home pages e no vocabulário ciber-bucólico da aldeia global. A absoluta superabundância de produtos nostálgicos comercializados pela indústria do entretenimento, ready-mades atraentes em sua maioria, refletem o medo de uma saudade irrefreável e do tempo não comercializável. A supersaturação, nesse caso, enfatiza a instabilidade fundamental da nostalgia. Com o decréscimo do papel da arte nas sociedades ocidentais, a exploração autoconsciente da saudade - sem paliativos improvisados e edulcorados evanesceu significativamente.

Nos velhos e bons tempos, a nostalgia era uma doença curável, perigosa, mas nem sempre letal. Sanguessugas, emulsões hipnóticas quentes, ópio ou uma viagem aos Alpes normalmente aliviavam os sintomas, mas nada comparado ao retorno à terra natal, o que se acreditava ser o melhor remédio para a nostalgia. Ao propor o tratamento para a doença, Hofer parecia orgulhoso de alguns de seus pacientes; para ele, a nostalgia era uma demonstração do patriotismo de seus concidadãos que amavam o charme de sua terra natal ao ponto de adoecerem. O surto de nostalgia simultaneamente reforçava e desafiava a concepção emergente de patriotismo e espírito nacional. Inicialmente, não ficava claro o que deveria ser feito com os soldados adoecidos durante as campanhas no exterior que amavam tanto sua terra natal que nunca desejaram deixá-la, ou, por esse motivo, morrer por ela. Quando a epidemia de nostalgia se espalhou além da guarnição suíça, um tratamento mais radical foi iniciado. Durante a Revolução Francesa de 1789, o médico francês Jourdain Le Cointe sugeriu que a nostalgia deveria ser curada infringindo dor e terror. Como evidência científica, ele apresentou um relato de um tratamento drástico levado a cabo com sucesso pelos russos. Em 1733, o exército russo foi tomado por nostalgia enquanto se arriscava na Alemanha, tornando a situação tão crítica que o general foi levado a encontrar um tratamento radical para o vírus nostálgico. Ele ameaçou dizendo que "o primeiro a adoecer seria enterrado vivo". O que era como a tradução literal de uma metáfora, uma vez que a vida em um país estrangeiro se parecia bastante com a morte. Há registros de que a punição foi efetivada em duas ou três ocasiões, o que felizmente curou o exército russo de reclamações de nostalgia (STAROBINSKI 1790, p. 96). ${ }^{3}$ (Não espanta que a saudade tenha se tornado uma parte tão importante da identidade nacional russa).

Como epidemia pública, a nostalgia se baseava em um senso de perda não limitado à história pessoal. Não era necessariamente uma perda que fosse prontamente lembrada, e tampouco que alguém soubesse necessariamente por onde procurar o que se perdeu. A nostalgia tornou-se cada vez menos curável. Ao final do século XVIII, os médicos descobriram que voltar ao lar nem sempre curava os sintomas. Na verdade, uma vez em casa, os pacientes morriam frequentemente. Por vezes, o objeto da saudade migrava para terras distantes

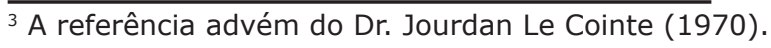


muito além dos limites da terra natal. Assim como hoje os geneticistas esperam identificar genes específicos para certas condições médicas, comportamentos sociais e até orientação sexual, os médicos dos séculos XVIII e XIX buscavam a medula da patologia nostálgica. No entanto, eles falharam ao procurar o lugar da nostalgia nas mentes e corpos de seus pacientes. Um médico argumentou que a nostalgia era uma hipocondria cardíaca que se desenvolve nos seus sintomas. De um mal tratável, a nostalgia tornou-se uma doença incurável. Um mal-estar provinciano, maladie du pays, tornou-se uma doença da era moderna, mal du siècle.

Minha hipótese é que a propagação da nostalgia ligava-se não somente ao deslocamento no espaço, mas também à mudança na concepção do tempo. A nostalgia foi diagnostica em um tempo no qual arte e ciência ainda não haviam cortado inteiramente seus cordões umbilicais e quando mente e corpo - saúde interna e externa - eram tratados simultaneamente. Este era um diagnóstico de uma ciência poética, mas não devemos sorrir condescendentemente para os diligentes médicos suíços. Nossos descendentes poderão poetizar a depressão e vê-la como uma metáfora para uma condição atmosférica global imune ao tratamento com Prozac. A nostalgia moderna é o luto pela impossibilidade do retorno mítico, pela perda de um "mundo encantado" com limites e valores claros. Ela pode ser uma expressão secular de um desejo espiritual pela unidade edênica do tempo e espaço antes da entrada na história. O nostálgico está em busca de um destinatário espiritual. Defrontando-se com o silêncio, ele procura 158 por sinais memoráveis, mal interpretando-os desesperadamente.

Em resposta ao Iluminismo, com sua ênfase na universalidade da razão, os românticos começaram a celebrar os particularismos do sentimento. A saudade de casa tornou-se um tropo central do "nacionalismo romântico" (HERDER 1972, p. 229-30). Não é surpreendente que, em vez de dentro dela, a consciência nacional desenvolver-se fora da comunidade. O nostálgico nunca é um nativo, mas sim um desterrado que faz a mediação entre o local e o universal. Muitas línguas nacionais, graças à apaixonada lembrança de Herder, tinham sua própria palavra para o anseio patriótico. Curiosamente, intelectuais e poetas de diferentes tradições nacionais começaram a afirmar que possuíam uma expressão especial para a saudade de casa que era radicalmente intraduzível: os portugueses tinham sua saudade, os russos, toska, os tchecos, litost', os romenos, dor - para não falar da alemã Heimweh e a espanhola mal de corazon. Todas essas intraduzíveis palavras da singularidade nacional revelaram-se sintomas da mesma emoção histórica. Enquanto os detalhes e sabores diferem, a gramática das nostalgias românticas é bastante similar em todo o mundo. "Sinto saudade, logo existo" era o lema romântico.

A nostalgia como emoção histórica apareceu durante o romantismo e é contemporânea ao nascimento da cultura de massa. Na metade do século XIX, a nostalgia institucionalizou-se em museus nacionais e provinciais, instituições patrimoniais e monumentos urbanos. O passado não era mais desconhecido ou desconhecível. O passado tornou-se "patrimônio". O ritmo acelerado da industrialização e modernização aumentou a intensidade do desejo popular 
por ritmos mais lentos do passado, por coesão social e tradição. Porém, essa obsessão com o passado revelou um abismo de esquecimento e acabou surtindo efeito inverso à sua própria preservação. Como sugeriu Pierre Nora, lugares de memória, ou lieux de memoire, são institucionalmente criados quando os meios de memória, os milieux de mémoire, desaparecem (NORA 1989, p. 7-24). É como se o ritual comemorativo pudesse ajudar a compensar a irreversibilidade do tempo.

No lugar de uma cura mágica para a nostalgia, apresentarei uma tipologia que pode esclarecer alguns mecanismos de sedução e manipulação da nostalgia. Diferencio dois tipos básicos de nostalgia: a restauradora e a reflexiva. A nostalgia restauradora enfatiza o nostos (casa) e enceta uma reconstrução transhistórica da terra perdida. A nostalgia reflexiva se desenvolve com a algia (o próprio anseio) e posterga o retorno à casa - melancolicamente, ironicamente, desesperadamente. Essas distinções não são absolutos binários e pode-se fazer certamente um mapeamento mais refinado das zonas cinzentas nos arredores das terras natais imaginadas. Desejo identificar as principais tendências e estruturas narrativas da trama nostálgica na produção de sentido para anseios e perdas que se pode ter. A nostalgia restauradora não se percebe como nostalgia, mas antes como verdade e tradição. A nostalgia reflexiva reside na ambivalência do pertencimento e saudade humanos e não se desvia das contradições da modernidade. A nostalgia restauradora protege a verdade absoluta ao passo que a nostalgia reflexiva a coloca em dúvida.

A nostalgia restauradora está no cerne do reavivamento nacional e religioso recentes. Ela apresenta dois enredos principais - o retorno às origens e a conspiração. A nostalgia reflexiva não segue uma trama única, mas sim explora formas de ocupar muitos lugares simultaneamente e de imaginar diferentes fusos horários. Ama os detalhes, não os símbolos. Na melhor das hipóteses, ela pode apresentar desafios criativos e éticos, não apenas de pretexto para melancolias noturnas. Esta tipificação da nostalgia permite-me distinguir entre, por um lado, a memória nacional baseada em uma única versão da identidade nacional e, por outro, a memória social, que consiste em quadros coletivos que marcam, mas não definem, a memória individual. A retórica da nostalgia restauradora não trata do "passado", mas antes de valores universais como família, natureza, pátria, verdade. A retórica da nostalgia reflexiva trata de viver o tempo fora do tempo e de aproveitar o presente fugaz.

Para compreender a nostalgia restauradora é importante distinguir entre os hábitos do passado e os hábitos de restauração do passado. Eric Hobsbawm diferencia o velho "costume" e as tradições inventadas do século XIX (HOBSBAWN 1983 , p. 2). As novas tradições se caracterizam por um grau de formalização simbólica e ritualização mais elevados do que eram os autênticos costumes e convenções camponesas a partir dos quais foram forjadas. Há dois paradoxos, portanto. Primeiro, quanto mais rápidos e devastadores os ritmos e escalas da modernização, tanto mais conservadoras e imutáveis tendem a ser as novas tradições. Segundo, quanto mais decisiva a retórica de continuidade com o passado histórico e a ênfase em valores tradicionais, tanto mais o passado é 
comumente apresentado de forma seletiva. "A inovação" da tradição inventada é "não se tornar menos nova por ser capaz de revestir-se facilmente de um caráter de antiguidade" (HOBSBAWN 1983, p. 5). Obviamente, a tradição inventada não significa uma criação ex nihilo ou um puro ato de construtivismo social. Ela se baseia no sentimento de perda da comunidade e de coesão e apresenta um modelo coletivo confortante para a saudade individual.

Há uma percepção de que, com a industrialização e secularização da sociedade iniciada no século XIX, um vazio de significado social e espiritual foi aberto. O que é necessário é uma transformação secular da "fatalidade em continuidade, da contingência em sentido" (ANDERSON 1991, p. 11). Mas essa transformação pode tomar caminhos diferentes. Ela pode aumentar as possibilidades de emancipação e as escolhas individuais, apresentando múltiplas "comunidades imaginadas" e meios de pertencimento, os quais não são exclusivamente sustentados em princípios étnicos ou nacionais. Ela pode também ser manipulada politicamente através de novas recriações de práticas comemorativas nacionais com o fim de restabelecer a coesão social, um sentimento de segurança e uma relação de obediência com a autoridade.

A nostalgia restauradora se caracteriza por duas tramas principais: a restauração das origens e a teoria da conspiração. A visão de mundo conspiratória reflete a nostalgia por uma cosmologia transcendental e uma concepção prémoderna simples do bem e do mal. Essa visão de mundo se baseia em um enredo transistórico único, um confronto maniqueísta entre o bem e o mal e a inevitável expiação do inimigo mítico. A ambivalência, a complexidade da história, a variedade de evidências contraditórias e a especificidade das circunstâncias modernas são assim apagadas, e a história moderna é vista como a realização de uma antiga profecia. Adeptos extremistas da teoria da conspiração imaginam que a casa está sempre sob cerco, exigindo a defesa contra o inimigo conspirador.

Restaurar (de re-staurare, re-estabelecer) significa um retorno à harmonia original, ao momento anterior ao momento edênico. Enquanto a nostalgia restauradora retorna e reconstrói uma terra natal com determinação paranoica, a nostalgia reflexiva teme o retorno com a mesma intensidade. Em vez de recriar a da pátria perdida, a nostalgia reflexiva pode desenvolver a criação da individualidade estética.

A nostalgia reflexiva se preocupa com o tempo histórico e individual, com a irrevogabilidade do passado e da finitude humana. Re-flexão significa nova flexibilidade, não o restabelecimento da harmonia. O foco aqui não repousa sobre a recuperação daquilo que se percebe como a verdade absoluta, mas com a consideração sobre a história e a passagem do tempo. Nostálgicos desse tipo são, frequentemente, nas palavras de Vladimir Nabokov: "amantes do Tempo, apreciadores da duração", ${ }^{4}$ que resistem às pressões externas por eficiência e experimentam o prazer sensível na tessitura do tempo não mensurável por relógios e calendários (NABOKOV 1990, p. 185).

${ }^{4}$ No original, lê-se: "amateurs of Time, epicures of duration" (NTs). 
As nostalgias restauradora e reflexiva podem ter sobrepostos seus quadros de referência, porém nunca coincidem nas suas narrativas e tramas identitárias. Em outras palavras, podem usar os mesmos símbolos e disparadores da memória, a mesma madaleine proustiana, mas contam histórias diferentes sobre ela. A nostalgia do primeiro tipo inclina-se para a cultura oral e símbolos pictóricos coletivos. A nostalgia do segundo tipo é mais orientada para uma narrativa individual que valoriza detalhes e signos da memória, ainda que perpetuamente suspenda a verdadeira volta à casa. Se a nostalgia restauradora termina por reconstruir emblemas e rituais sobre a casa e a pátria numa tentativa de domesticar e espacializar o tempo, a nostalgia reflexiva valoriza fragmentos esparsos da memória e temporaliza o espaço. A nostalgia restauradora levase muito à sério; a nostalgia reflexiva, ao contrário, pode ser irônica e bemhumorada. Ela revela que a saudade e o pensamento crítico não se opõem, assim como as memórias afetivas não nos impedem de ter compaixão, emitir um juízo ou reflexão crítica.

A nostalgia reflexiva não finge reconstruir o espaço mítico chamado lar; ela é "enamorada da distância, não do próprio referente" (STEWART 1984, p. 145). Esse tipo de narrativa nostálgica é irônica, inconclusiva e fragmentária. Os nostálgicos do segundo tipo conhecem a distância entre identidade e semelhança; a casa está em ruínas ou, ao contrário, acaba de ser reformada e gentrificada além da possibilidade de ser reconhecida. É precisamente essa desfamilirarização e sentido de distância que os impele a contar sua história, a narrar a relação entre passado, presente e futuro. Através dessa saudade, descobrem que o passado não é aquilo que não existe mais, mas, para citar Bergson (1988, p. 240), o passado é algo que "pode atuar e atuará ao inserir-se numa sensação presente da qual retira sua vitalidade". O passado não é feito à imagem do presente ou visto como presságio de algum desastre presente; ao contrário, é uma miríade de potencialidades que o passado abre, possibilidades não teleológicas de desenvolvimento histórico. Não necessitamos de um computador para acessar as virtualidades de nossa imaginação: a nostalgia reflexiva abre múltiplos planos de consciência. Para Marcel Proust, a lembrança é uma aventura imprevisível na percepção sincrética, quando palavras e sensações táticas se sobrepõem. Nomes de lugares abrem mapas mentais e o espaço desdobra-se em tempo. "A recordação de certa imagem não é senão saudade de certo instante; e as casas, os caminhos, as avenidas são fugidios, infelizmente, como os anos", escreve Proust ao final de No Caminho de Swan (PROUST 1989, p. 462). Portanto, é essa memorável evasão literária que importa e não a volta para casa.

No século XXI, milhões de pessoas se encontram desterradas, vivendo voluntária ou involuntariamente no exílio. Histórias de imigrantes constituem as melhores narrativas da nostalgia - não apenas porque sofrem de nostalgia, mas também porque a desafiam. Essas histórias frequentemente enquadradas como projeções para a nostalgia dos outros que falam a partir de um lugar muito mais seguro. Imigrantes compreendem os limites da nostalgia e a ternura do que chamo de "intimidade diaspórica", a qual valoriza afinidades eletivas, 
estrangeiras. ${ }^{5}$ A intimidade diaspórica não se opõe à desfamiliarização ou desenraizamento embora seja constituída por estes. Tem-se falado tanto do feliz retorno à terra natal/casa que é hora de fazer justiça às histórias do não retornar e do enaltecimento relutante do exílio. No caso de alguns escritores e artistas exilados, não retornar para casa transforma-se em força artística central, uma vida caseira feita no texto e em obras de arte, bem como em estratégia de sobrevivência. Exilados comuns frequentemente se tornam artistas na vida que reconstroem a si mesmos e a sua segunda casa com grande engenhosidade. A impossibilidade de voltar para casa é, simultaneamente, uma tragédia pessoal e uma força poderosa. $O$ que não significa que a nostalgia não exista nestes casos, apenas que esse tipo de nostalgia previne a restauração do passado. A intimidade diaspórica não garante uma fusão emocional imediata, apenas uma afeição precária - não menos profunda, ainda que consciente de sua transitoriedade.

As construções e reconstruções arquitetônicas contemporâneas apresentam diferentes encarnações materiais da nostalgia. Na Moscou pós-soviética, o começo da virada nostálgica na esfera pública foi marcado pela reconstrução da Catedral de Cristo Salvador (1994-1997), que fora brutalmente destruída na década de 1930. O promissor debate inicial sobre as possibilidades arquitetônicas para o lugar, o qual inspirou diversos projetos grandiosos e muita destruição, encerrou-se com a edificação em concreto de uma réplica exata da catedral e o apagamento de todas as controvertidas memórias políticas e arquitetônicas relacionadas ao lugar. De forma semelhante, nos territórios da antiga Iugoslávia, encontramos velhas igrejas e mesquitas arruinadas enquanto novas e imensas catedrais e mesquitas são construídas fora dos centros urbanos que foram historicamente espaços multiétnicos. Se globais no estilo e no financiamento, elas afirmam, contudo, identidades étnicas e religiosas locais frequentemente imaginadas no estrangeiro - exemplos de nostalgia restauradora que vão além e, comumente, contra a restauração de tecidos urbanos etnicamente integrados ainda existentes. Por outro lado, a nostalgia reflexiva nos domínios da arquitetura valoriza um certo tipo de "ruinofilia" na esfera pública, um tipo de amor e tolerância por ruínas modernas que mantêm vivas memórias da destruição e de múltiplas histórias controversas, de temporalidades coexistentes. Inúmeros edifícios contemporâneos - desde os Tate Modern até projetos menores de arquitetura efêmera e de transição - incorporaram e preservam ruínas industriais, reabitando-as e reciclando-as criativamente. As ruínas da modernidade apontam tanto para os enganos da tecnologia moderna quanto para os da teleologia, nos lembrando de nosso mundanismo e história material comuns.

A primeira década do século XXI não é caracterizada pela busca por novidades, mas pela proliferação de nostalgias que estão frequentemente em desacordo entre si. Nostálgicos cyberpunk e hippies nostálgicos, nacionalistas nostálgicos e nostálgicos cosmopolitas, ambientalistas nostálgicos e metrófilos (amantes da cidade) nostálgicos trocam candentes farpas virtuais na blogosfera.

\footnotetext{
${ }^{5}$ Ver "intimacy", American Heritage Dictionary (1982, p. 672).
} 
A nostalgia, como a globalização, existe no plural. Estudar a sociologia, a política e a etnografia da nostalgia, suas micropráticas e meganarrativas, permanece tão urgente quanto sempre foi. É sempre importante levantar a questão: quem está falando em nome da nostalgia? Quem é seu ventríloquo? A nostalgia do século XXI, como sua contraparte seiscentista, produz epidemias de nostalgia fingida. Por exemplo, o problema com a nostalgia no Leste Europeu é que ela parece muito mais ubíqua do que realmente é. Isso pode parecer contra-intuitivo. Europeus ocidentais com frequência projetam nostalgia sobre o Leste Europeu como meio de legitimar o suposto "atraso" deste último e não confrontar as diferenças em sua própria história cultural.

Um exemplo sintomático foi o sucesso do filme Adeus Lênin!, que fala sobre os paradoxos da ost-algia 6 na Alemanha e se empenhou em um amplo apelo nostálgico. Adeus Lênin! tinha uma concepção bem-humorada: uma devotada alemã oriental, que personifica os sonhos do regime de Honecker, tem um acidente grave e permanece em coma enquanto o Muro desmorona. Quando ela acorda, seus queridos filhos trabalham duro para preservar completamente sua ilusão nostálgica, desde os desaparecidos picles da Alemanha oriental até as reportagens de televisão censuradas. Aos olhos dos antigos "ossies", Adeus Lênin! foi o trabalho de diretores "wessie" que tentavam imaginar e empacotar ostalgia de seus concidadãos extramuros. A ost-algia do filme é uma joint venture: ela mescla sonhos ocidentais da terceira via e mitologias orientais do cosmos. O desejo mimético pelas nostalgias dos outros vai além do Ocidente-Oriente europeu: europeus e americanos, em geral conscientes de seu desejo mais ou menos genuíno de compreender o "outro" oriental, transformaram o sonho do multiculturalismo em um exotismo reverso. Eles exageraram na alteridade do outro, preservando a diferença nostálgica enquanto esqueceram as diferenças internas às culturas estrangeiras e suas formas de autoritarismo e manipulação midiática. Se uma questão de mágoas passadas ou autoafirmação atual, devese sempre reconhecer a modernidade do outro, o mundo compartilhado de tradições reinventadas e os transnacionais sonhos individuais por reforma e melhorias. Enquanto a estória que os nostálgicos contam é uma volta ao lar localista, a forma desta estória dificilmente é local. Nostalgias contemporâneas podem ser entendidas como séries de enredos interculturais que migram, estendendo-se para além das fronteiras nacionais. ${ }^{7}$

\footnotetext{
${ }^{6} \mathrm{O}$ neologismo ost-algia é a tradução para a palavra alemã "Ostalgie", que designa a nostalgia pela vida na antiga Alemanha Oriental, resulta da junção das palavras Ost (leste) e Nostalgie (nostalgia). Assim também ossie (que vem de Ost) designava na linguagem cotidiana e algo jocosa os habitantes do lado oriental, tendo por contraparte wessie (de West), os habitantes do lado ocidental da Alemanha (NTs).

${ }^{7}$ A Nostalgia tende a colonizar a política e a história. Como a imaginação conspiratória, o ponto de vista nostálgico não nos permite ver nada além da nostalgia. Reiteradamente, a nostalgia restaurativa relaciona-se de perto com a política. Na imprensa de hoje, com frequência, qualquer um encontra referências à nostalgia da Guerra Fria quando debatendo a situação da Rússia contemporânea. Paradoxalmente, é exatamente o mesmo medo de cair nas narrativas da Guerra Fria que deferiu as discussões das mudanças políticas na Rússia e da notável persistência política do antigo aparato de estado soviético em suas novas vestes. A economia de livre mercado provou não ser nenhuma panaceia para a mudança democrática; muitas instituições democráticas e canais de imprensa não estatal foram fechados na Rússia de Putin sob pretextos econômicos como o da "disputa entre parceiros de negócios". A esta altura já é óbvio que a economia capitalista consegue conviver pacificamente com o estado autoritário e sua ideologia nacionalista nostálgica. Para compreender a situação da Rússia, não se pode mais permanecer ao nível da representação cultural; precisa-se observar a política. Nostalgia restaurativa é com frequência patrocinada de cima, contudo, é populista, por mais familiar e "popular" que aparente ser.
} 
Concluindo, não há muita novidade sobre a nostalgia contemporânea. Ao contrário do que diz a grande atriz Simone Signoret, que intitulou sua biografia Nostalgia Isn't What It Used to Be (A nostalgia não é mais o que costumava ser), a estrutura da nostalgia ainda é, em muitos sentidos, aquilo que costumava ser, a despeito das mudanças de moda e avanços na tecnologia digital. Ao fim, o único antídoto para a ditadura da nostalgia talvez seja a dissidência nostálgica. A nostalgia pode ser uma criação poética, um mecanismo individual de sobrevivência, uma prática da contracultura, um veneno, ou uma cura. É de nossa alçada assumir responsabilidade pela nossa nostalgia e não deixar que os outros a "pré-fabriquem" para nós. 0 "passado usável" pré-embalado pode não ser útil para nós se quisermos criar conjuntamente nosso futuro. Talvez, sonhos de terras natais imaginadas não possam e não devam ganhar vida. Às vezes é preferível (pelo menos, na perspectiva desta nostálgica autora) deixar os sonhos quietos, que eles não sejam nem mais nem menos do que sonhos, e não os parâmetros para o futuro. Enquanto a nostalgia restauradora retorna e reconstrói a terra natal de alguém com determinação paranoica, a nostalgia reflexiva teme retornar com a mesma paixão. O lar, finalmente, não é um condomínio fechado. $O$ paraíso na Terra pode se mostrar como outra vila Potemkin ${ }^{8}$ sem nenhuma saída. O imperativo da nostalgia contemporânea é estar saudoso da casa e enfastiado da mesma - ocasionalmente, ao mesmo tempo.

\section{Referências bibliográficas}

American Heritage Dictionary. Boston: Houghton Mifflin, 1982.

ANDERSON, Benedict. Imagined Communities. New York: Verso, 1991.

BERGSON, Henri. Matter and Memory. New York: Zone, 1988.

BOYM, Svetlana. The future of nostalgia. New York: Basic, 2001.

DAVIS, Fred. Yearning for yesterday: a sociology of nostalgia. New York: Free, 1979.

EISENSTADT, S. N. Multiple modernities. Daedalus, v. 129, n. 1, p. 1-29, 2000.

ERNST, Fritz. Vom Heimweh. Zurich: Fretz \& Wasmuth, 1949.

GAONKAR, Dilip P. (Ed.). Alternative modernities. Durham: Duke University Press, 2001.

HERDER, Johann Gottfried von. Correspondence on Ossian. In: FELDMAN, Burton; RICHARDSON, Robert D. The rise of modern mythology 16891860. Bloomington: Indiana University Press, 1972, p. 229-230.

\footnotetext{
8 Vila Pomtenkin designa, em política como também em economia, qualquer construção, real ou ilusória, feita para enganar, para fazer parecer que uma situação é melhor do que de fato é. O termo vem das histórias sobre construções efêmeras de uma vila inteira erguidas por Grigory Potemkin ao longo do rio Dnieper na viagem de Catarina II à Crimeia, após sua anexação pela Rússia, no século XVIII; os cenários eram combinados e recombinados ao longo do rio à medida que a comitiva imperial passava de um ponto a outro em sua jornada fluvial para dar a impressão de que o espaço conquistado ao Império Otomano vinha sendo ocupado (NTs).
} 
HOBSBAWM, Eric. Introduction: Inventing Traditions. In: HOBSBAWM, Eric; RANGER, Terence (Ed.) The Invention of Tradition. Cambridge: Cambridge University Press, 1983.

HOFER, Johannes, Medical Dissertation on Nostalgia. Bulletin of the Institute of the History of Medicine, v. 2, 1934.

KAMMEN, Michael. Mystic chords of memory: the transformation of tradition in American culture. New York: Knopf, 1991.

MAIER, Charles S. The End of Longing? Notes toward a history of postwar German national longing. In: BRADY, John S.; CRAWFORD, Beverly; WILIARTY, Sarah Elise (Ed.) The postwar transformation of Germany: democracy, prosperity, and nationhood. Ann Arbor: University of Michigan Press, 1999.

McCANN, Willis H. Nostalgia: a descriptive and comparative study. Journal of Genetic Psychology, n. 62, p. 97-104, 1943.

NABOKOV, Vladimir. On Time and its Texture. In: Strong opinions. New York: Vintage, 1990.

NORA, Pierre. Between memory and history: Les Lieux de Mémoire. Representations, n. 26, p. 7-24, 1989.

PETERS, Roderick. Reflections on the origin and aim of nostalgia. Journal of Analytic Psychology, n. 30, p. 135-148, 1985.

PHILLIPS, James. Distance, Absence and Nostalgia. In: IHDE, Don; SILVERMAN, Hugh (Ed.). Descriptions. Albany: State University of New York Press, 1985, p. 64-75.

PROUST, Marcel Proust. Swann's Way. New York: Vintage International, 1989.

ROSEN, George Rosen. Nostalgia: a forgotten psychological disorder. Clio Medica, v. 10, n. 1, p. 28-51, 1975.

STAROBINSKi, Jean. The Idea of Nostalgia. Diogenes, n. 54, p. 81-103, 1966.

STEWART, Susan. On longing: narratives of the miniature, the gigantic, the souvenir, the collection. Baltimore: Johns Hopkins University Press, 1984. 
Em pauta 


\section{Breves considerações sobre "Os lugares dos historiadores e da história na sociedade brasileira"}

\section{Brief considerations on "Places of historians and history in Brazil"}

\section{Caroline Silveira Bauer}

caroline.bauer@ufrgs.br

Professora Adjunta 1-A

Universidade Federal do Rio Grande do Sul

Avenida Bento Gonçalves, 9500 - Prédio 43311, Sala 222

91509-900 - Porto Alegre - Rio Grande do Sul

Brasil

Palavras-chave

História do tempo presente; Historiografia brasileira; História da historiografia.

Keywords

History of present time; Brazilian historiography; History of Historiography. 
Embora os questionamentos sobre a função social e as utilidades do conhecimento histórico nunca tenham abandonado os historiadores, considero que nos últimos anos essas preocupações adquiriram outros contornos, e não deixaram de ser expressas nas temáticas dos Simpósios Nacionais de História, promovidos pela ANPUH. Às vésperas da realização de mais uma edição, em 2017, com a temática "Contra os preconceitos: história e democracia", vejo uma continuidade nas inquietações da área, pelo menos, desde 2013, quando um mês após a eclosão das jornadas de junho, realizou-se em Natal o simpósio - coincidentemente intitulado "Conhecimento histórico e diálogo social" - que definiu o tema e a agenda para os dois anos seguintes: "Lugares dos historiadores: velhos e novos desafios".

Realizando uma rápida retrospectiva, no interregno entre as edições de 2013 e 2015, além dos desdobramentos das manifestações de 2013, houve a rememoração dos 50 anos do golpe civil-militar de 31 de março de 1964, a realização de eleições presidenciais em uma conjuntura de extrema polarização política, o desenvolvimento dos trabalhos e a entrega do relatório da Comissão Nacional da Verdade (CNV), e os primeiros rumores sobre a possibilidade de impeachment da então presidenta, legitimamente eleita, Dilma Rousseff. E esta foi apenas a conjuntura nacional; no mundo, guerra na Síria e a destruição de patrimônios históricos mundiais, crise entre Ucrânia e Rússia, genocídio na Nigéria, atentados terroristas em Paris, e o avanço do Estado Islâmico, são apenas alguns exemplos destes dois anos que mais parecem terem comportado duas décadas.

168 Assistimos atônitos - muitas vezes, em tempo real - a reconfiguração dos tempos da justiça e da política, anteriormente marcados por um ritmo mais estável, lento; a justiça, a partir de uma série de medidas imediatistas, instrumentalizada pela mídia e pelos outros poderes; a política, pelo descaso com a democracia ou as regras do jogo democrático. Nesta conjuntura nacional e internacional que questionava certezas consideradas inabaláveis, me pareceu extremamente oportuno que a conferência de abertura do XXVIII Simpósio Nacional de História, realizado Florianópolis em julho de 2015, proferida pelo então presidente da entidade, Rodrigo Patto Sá Motta, se intitulasse "Os lugares dos historiadores e da história na sociedade brasileira" e suscitasse o debate sobre nossa função social como historiadores e nosso posicionamento frente a esses episódios.

Meu objetivo com este comentário é debater alguns aspectos apresentados por Rodrigo, mais que apresentar discordâncias sobre sua fala, que considerei bastante adequada para a ocasião e correspondente ao lugar que o conferencista ocupava. Tratam-se mais de complementações ao debate instaurado sobre os lugares que os historiadores têm ocupado, ou devem ocupar.

Patto apresenta em sua conferência três espaços em que, em seu ponto de vista, entrecruzam-se as dimensões acadêmico-profissionais e ético-sociais dos historiadores: em nível representativo, na própria ANPUH; no espaço público; e nas escolas.

Nas últimas décadas houve um crescimento exponencial do número de cursos de graduação e pós-graduação em história e, por consequência, no contingente 
de alunos e profissionais que se formam todos os anos. Esse movimento fez com que a ANPUH, para além das defesas particulares de interesses enquanto entidade representativa, reafirmasse uma perspectiva política ao enfrentar desafios como a regulamentação da profissão do historiador - uma temática na qual não existe consenso entre os profissionais.

Neste primeiro ponto, as novidades são mais conjunturais que de atuação ou epistemológicas. O grande desafio para a instituição nos últimos anos, do meu ponto de vista, tem sido repensar-se e se indagar quanto à possibilidade de unicidade representativa frente à proliferação de outras organizações, nacionais e internacionais, mais próximas às temáticas de trabalho dos historiadores.

Quanto o espaço público, embora a presença de historiadores em espaços fora da academia ou no âmbito escolar não seja nenhuma novidade, tendo, inclusive, fomentado debates sobre a pertinência de uma interferência baseada na figura de autoridade ou da expertise (HABERMAS 2001), essa discussão tem adquirido novas significações na atual conjuntura, não somente sobre as indagações quanto a este lugar, que Rodrigo se refere como "aos espaços e locais de circulação de ideias e opiniões, em especial as mídias tradicionais e as novas redes sociais", além de "outras esferas e sociabilidades" (MOTTA 2016, p. 325); mas pelas demandas sociais encaminhadas aos historiadores e pelo novo projeto para a educação pública no Brasil, que será discutido posteriormente.

Esse debate parece ter extrapolado os antigos limites da discussão sobre os ofícios do historiador e do jornalista, para centrar-se na temática da divulgação histórica, da existência de outros saberes históricos que não o escolar e o acadêmico, dos nichos editoriais e outras questões mercadológicas, da demanda por consumo de história, etc. Além dessas problemáticas, que vinculam-se diretamente à atuação profissional, existem as implicações cívicas, éticas e morais do posicionamento dos historiadores na esfera pública.

Concordo plenamente com Patto quando afirma que essas dimensões acadêmico-profissionais e ético-sociais dos historiadores estão indissociavelmente ligadas a um posicionamento político.

Em suas palavras,

Por esse roteiro chegamos ao lugar político da história. Eis aí uma questão essencial: a política e o político estão inextricavelmente implicados na nossa disciplina. É impossível desconectar o conhecimento histórico da política, afinal, o nosso campo de saber nasceu no calor das disputas políticas e fortemente ligado ao Estado, que sempre se ocupou dos discursos e representações sobre o passado, invariavelmente tentando controla-los. Em séculos recentes, ou melhor, em décadas recentes, felizmente alcançamos condições de produção do conhecimento em clima de liberdade, inclusive com a possibilidade de criticarmos o Estado - e como criticamos! Mas, isso não significou uma redução do lugar político ocupado pela história. Ao contrário, o nosso campo continua tão imerso nas disputas políticas como sempre esteve. A diferença é que hoje há mais espaço para divergências e controvérsias, mais liberdade (MOTTA 2016, p. 326).

Complementaria essa observação salientando a relação que se estabelece no espaço público, às vezes, de forma problemática, entre o conhecimento 
histórico e demais representações do passado. Sem hierarquiza-las, é necessário entender os espaços editoriais conferidos a cada uma delas, as possibilidades de divulgação de determinadas versões que se opõe a memórias e culturas históricas hegemônicas e as resistências decorrentes a uma possível incorporação destas novas interpretações ao quadro de uma "história nacional".

Além disto, é necessária uma relativização da liberdade de ensino, condicionada em grande parte, mas não somente, pelas proposições do projeto Escola Sem Partido, que falaciosamente denuncia uma ideologização do ensino e apregoa uma neutralidade na construção do conhecimento. Não irei me alongar explicitando os pormenores e as implicações do projeto, apenas ressaltar a tentativa de cerceamento dessa liberdade afirmada por Patto, bem como a possibilidade de que esse projeto fomente um relativismo exacerbado, ao defender um "pluralismo de concepções de mundo" que pode englobar versões criminosas, negacionistas e revisionistas sobre determinadas práticas, posturas e acontecimentos históricos.

Devemos estar atentos ao proselitismo político, mas não compactuar com uma equiparação entre todas as narrativas, como é salientado no texto da conferência:

Trocando em miúdos, a aceitação do pluralismo não inclui compactuar com preconceitos e diferentes formas de opressão, como o racismo, a violência contra as mulheres, a homofobia, a intolerância religiosa entre outros, que devem ser denunciados e combatidos. De igual forma, e isso é uma preocupação atual, devemos ter tolerância zero para os discursos autoritários que defendem o retorno à ditadura, sob qualquer pretexto (MOTTA 2016, p. 329).

Em outro trecho, o historiador cita uma das principais dificuldades do debate sobre um pluralismo de interpretações no espaço público, especificamente no ambiente escolar. Trata-se de um desafio que se explicita todas as vezes quando somos inquiridos sobre "quem tem razão" em uma controvérsia sobre determinado acontecimento, do desafio de ensinar que a história é construída a partir de versões, ou quando são apresentados os argumentos de liberdade de expressão e opinião para a disseminação de discursos de ódio, para além da apologia da ditadura civil-militar, que alimenta certo saudosismo em setores da sociedade brasileira:

Importante refletir sobre esse problema, também, tendo em vista a sua repercussão nos espaços de divulgação pública e de formação escolar. Considerando, em especial, o caso do ensino básico, o impacto do relativismo gera confusão e insegurança em relação ao valor do conhecimento histórico, além de disseminar a compreensão equivocada de que qualquer versão histórica tem igual valor (MOTTA 2016, p. 330).

Ainda sobre o espaço público, Patto faz referência à controvérsia sobre a participação de historiadores na composição da Comissão Nacional da Verdade, um dos temas que que mais polarizou as opiniões dos profissionais nos últimos tempos. Podem-se estabelecer paralelos nos debates ocorridos em 
países europeus em decorrência da presença de historiadores como peritos e testemunhas em processos judiciais contra crimes de lesa humanidade ou na investigação de ações revolucionárias (GINZBURG 1993; ROUSSO 1998).

Quanto à participação de historiadores na CNV, a ANPUH já havia se manifestado favoravelmente durante a gestão anterior, presidida por Benito Bisso Schmidt, no momento em que se aprovara a lei e se iniciara os debates sobre a composição da comissão. Nesse interregno, a associação realizou gestões para a indicação de um historiador para compor o grupo que seria responsável por coordenar os trabalhos de investigação e pesquisa.

Em nota intitulada "Comissão da Verdade: entre a memória e a história", divulgada no dia 12 de janeiro de 2012, no site da associação pela gestão 20112013, há um questionamento sobre os objetivos da comissão, que extrapolariam funções memoriais relativas à indenização e à reparação:

Porém, é preciso reconhecer que, se, por um lado, as reivindicações de cunho memorial são justificadas e importantes, elas não são suficientes. A memória é sempre ligada aos afetos, a identidades específicas, a sentimentos muitas vezes autocentrado do tipo: 'você não passou por isso, então não pode entender e julgar o que ocorreu'. Por isso, é tão importante que as lembranças sejam compreendidas à luz da História, forma de conhecimento do passado ligada à razão, ao intelecto, ao distanciamento, à tentativa de pensar o que ocorreu de maneira global e articulada. Obviamente, o historiador nunca é neutro e imparcial, ele também é sujeito de seu tempo. Porém, ao longo de sua formação, desenvolve habilidades como a pesquisa em arquivos, a crítica documental, a interpretação de testemunhos e a coleta e análise de fontes orais que Ihe permitem formular questões menos emocionais e mais balizadas por referências conceituais e metodológicas próprias de um conhecimento científico que tem por objetivo compreender, a partir da análise de fontes históricas, as tramas do passado (ainda que recente). Por esse motivo, a ANPUH - Associação Nacional de História, entidade que congrega aproximadamente quatro mil profissionais de História atuantes no ensino, na pesquisa e nas instituições voltadas à preservação do patrimônio, julga fundamental a participação de historiadores profissionais na Comissão da Verdade (ANPUH 2012, grifos no original).

E segue, salientando a autoridade dos historiadores para lidar com essas questões:

Eles têm o dever e a capacidade de pensar os temas tratados em tão importante fórum não apenas pelas lentes afetivas da memória, mas também pela perspectiva racional da História. Por isso, sua presença é imprescindível nos trabalhos da Comissão da Verdade e nos debates por ela suscitados que, com certeza, mobilizarão a sociedade brasileira no próximo ano (ANPUH 2012).

Pode-se afirmar que Patto corrobora esse posicionamento, embora não se manifeste diretamente à $\mathrm{CNV}$, mas sim quanto ao posicionamento de historiadores nesses debates:

[...] historiadores são constantemente chamados a tomar parte do debate.

E não deveriam se furtar a esse papel, que ao mesmo tempo provoca 
o dever profissional e toca a nossa obrigação cívica. O conhecimento histórico é importante elemento na formação da opinião política das pessoas e, nesse ponto, temos muito a oferecer (MOTTA 2016, p. 327).

Porém, como citado anteriormente, nem todos os profissionais foram favoráveis à participação de historiadores na comissão. Um dos exemplos mais notáveis foi de Carlos Fico, pesquisador da ditadura civil-militar, que se posicionou contrariamente em uma vídeo-palestra em seu blog.

A argumentação do historiador centrava-se na questão da verdade em história:

Comissões como essa tendem a constituir uma narrativa oficial, unívoca. As correntes teóricas, ao longo do século XX (como os Annales e o marxismo), lutaram exatamente contra isso e hoje, em termos epistemológicos, todos reconhecemos que a multiplicidade de interpretações co-possíveis é a base principal do processo social de construção de um conhecimento histórico eficaz, esclarecedor, que não se pretende uma "verdade", mas uma forma de entendimento que contribua para a compreensão refinada da experiência humana em toda a sua complexidade (FICO 2011).

Pela impossibilidade de sintetizar os múltiplos posicionamentos sobre o regime de verdade na história, cabe salientar que a posição tomada por Patto em sua conferência aproxima-o dos historiadores que creem na possibilidade de afirmação de uma verdade mínima sobre determinados acontecimentos, em um claro posicionamento contra o relativismo extremado, o revisionismo e o negacionismo:

Nos dias que correm, a questão da verdade não é debate restrito ao universo acadêmico, com repercussão somente nas polêmicas sobre os limites do conhecimento. Neste momento, em que estão em disputa representações sobre o passado recente de autoritarismo e violência, a demanda por verdade implica também desafios de ordem política e jurídica. Quando entram no foco da história os regimes autoritário-repressivos e, pensando de maneira mais ampla, qualquer forma de violência e opressão, os argumentos relativistas e hipercéticos, que são populares em alguns meios acadêmicos, revelam melhor as suas limitações. O investigador que atua nesse terreno não pode adotar o argumento relativista, ou seja, a posição de que discursos com pretensão à verdade devem ser desprezados como puro resquício do positivismo. A realidade é apenas um texto? Ela não passa de uma construção do historiador? Dá para aceitar tais postulados quando tratamos de temas como golpe de Estado, tortura, violência, trabalho escravo e censura? Não pode haver mesmo representações verdadeiras acerca da história? (MOTTA 2016, p. 329).

Novamente reforça-se a importância da participação dos historiadores nos debates públicos, agora argumentadas em função das implicações éticas deste posicionamento:

Vale a pena insistir sobre a manipulação em torno de 1964, pois muitos atores estão formando a opinião de certos grupos com base em representações ligeiras sobre a ditadura. Parece-me que aqui é fundamental a nossa atuação. Eis aí, portanto, um lugar chave para o 
historiador: o espaço público, o debate político, de que somos partes integrantes, inexoravelmente (MOTTA 2016, p. 328).

Nesta complexa interação entre ética, história e verdade, acredito que uma das principais contribuições vem de Mateus Pereira. Sem a pretensão de advogar por um monopólio do passado por parte da história, assim como o privilégio da condução dos debates públicos, pode-se adotar a postura recomendada pelo autor, de pensar a crítica histórica como uma função mediadora e qualificadora entre as diversas memórias e representações do passado presentes nas batalhas para conferir sentido ao passado, contribuindo "ao oferecer opções éticas melhores e mais justas a partir da sua função crítica" (PEREIRA 2015, p. 895). Em outras palavras, podemos pensar em um engajamento marcado pelo giro ético-político da história, sem desconsiderar alguns cânones científicos.

O terceiro e último lugar citado por Patto é o campo do ensino de história. Embora amparado nos debates dos projetos de lei que previam a reforma do ensino médio, sua fala datada de 2015 não previra que seria possível, em 2017, aprovarem o fim da obrigatoriedade do ensino de história nesse nível de ensino.

Embora minha posição seja contrária a essa reforma, acredito que algum tipo de modificação deveria ser feita no ensino médio, que, hoje em dia, se configura como uma mera repetição de conteúdos do ensino fundamental. Como afirmado por especialistas, a educação básica é um espaço de disputas políticas e de projetos educacionais.

Patto afirma que pensar a necessidade ou a obrigatoriedade do ensino de história significa refletir sobre o lugar da história e do historiador na sociedade de uma forma mais geral:

Por isso, reiterando, é necessário levantar questões que ajudem a pensar o nosso lugar na sociedade. Então, perguntemo-nos ainda uma vez: por que a história (por certo, a história acadêmica, crítica etc.)? Por que a sociedade e o Estado deveriam manter o lugar privilegiado que essa disciplina ocupa tradicionalmente? Ainda é justificável o investimento na história? Afinal, não estariam superados os contextos políticos que produziram o interesse pela história, em especial o impulso para construir identidades nacionais e fortalecer as organizações estatais correspondentes? Se o Estado nação que institucionalizou a história está em crise, também ela não estaria em vias de superação como campo de saber relevante? Se não há mais horizonte de expectativa e estamos condenados a um eterno presente e à memorialização nostálgica do passado, para que a história (MOTTA 2016, p. 333).

Nesse sentido, creio que deveríamos nos questionar, com sinceridade e sem receio a enfrentar a questão, de por que a história deve ser uma disciplina obrigatória na educação básica. Essa resposta está condicionada, inevitavelmente, às concepções de história, de sua função social, da crença em uma possibilidade de pedagogia do passado, etc, e a resposta dada pelo conferencista me parece bastante importante pela síntese que confere ao seu posicionamento ao longo da fala:

A história não é magistra vitae, impossível acreditar ainda nessa fórmula. Muitos atores nada aprenderam com a experiência do passado e repetiram 
os mesmos erros. Porém, o conhecimento histórico pode contribuir para a formação de cidadãos críticos, ao oferecer-Ihes oportunidade de analisar o seu lugar na experiência temporal e escolher caminhos de ação. A história ainda é indispensável para compreender o mundo e para fundamentar as decisões atuais, na medida em que coloca em perspectiva a experiência humana no tempo. Recuperando o que foi dito antes, como é possível a um cidadão formar sua opinião e valores políticos sem tomar como referência experiências passadas, mesmo que seja para recusá-las e buscar novas alternativas? A história não é mais necessária para construir a identidade nacional, pelo menos não no sentido que esse projeto teve no século XIX. Mas ainda é útil ao esforço de entender o que somos e a conjecturar sobre o que desejamos ser. A pesquisa histórica segue importante para entender esse pedaço do Globo a que chamamos Brasil. Como ele se formou em conexão com outros espaços da América, da África, da Europa e da Ásia? (MOTTA 2016, p. 333).

Por fim, gostaria de evidenciar duas ausências na fala de Rodrigo. A primeira, trata-se de uma renegação comum à área, que apenas recentemente despertou o interesse dos pesquisadores. Historiadores refletindo sobre sua prática e seus lugares de atuação; questões sobre a utilidade, sobre a função da história, e as dimensões éticas do papel social do historiador, enquanto produtor de narrativas históricas e cidadão; todas essas reflexões ocupam um espaço bastante significativo nos questionamentos sobre o ofício, mas pouco se fala sobre os posicionamentos dos historiadores frente às múltiplas temporalidades (AVELAR 2015).

Não menos importante, a segunda, em uma problematização mais ampla sobre lugares, não somente aqueles espaciais, diz respeito às mudanças ocorridas nos lugares que têm sido destinados na historiografia pelas ditas "minorias", que até bem pouco tempo ocupavam um não-lugar nas narrativas historiográficas. Para além da preocupação com os lugares de fala desses grupos, o aumento significativo de pesquisas sobre etnias, gênero, raça, sexualidade tem despertado uma série de problemáticas para os historiadores, como a intersecção da história profissional e seus procedimentos com a história pública, o academicismo e a militância, as dimensões éticas de determinadas representações do passado, etc.

O limite de páginas imposto a esse comentário, bem como a impossibilidade de uma resposta mais imediata, não permitiu que eu desenvolvesse uma questão que me acompanhou durante a escrita desse texto: por que em momentos de crise costuma-se voltar à discussão sobre o papel social do historiador, sobre suas ocupações, seus posicionamentos, etc.? O que esse incessante questionamento em períodos difíceis traduz? Estaríamos desiludidos com a possibilidade de aprendizado com a história, alimentando com essa postura certa melancolia? Consideraríamos a limitação de nossa ação como profissionais?

A apresentação desses questionamentos no penúltimo parágrafo desse texto é uma fuga consciente, como afirmei anteriormente, pela dificuldade em responder satisfatoriamente. Porém, mesmo que, como historiadora profissional, não predique previsões históricas, não faltarão crises para seguirmos nos questionando. 


\section{Referências bibliográficas}

ANPUH. Comissão da Verdade: entre a memória e a história. Disponível em: http://site.anpuh.org/index.php/2015-01-20-00-01-55/noticias2/ item/543-posicao-da-anpuh-sobre-a-participacao-dos-historiadores-nacomissao-da-verdade. Acesso em: 19 mar. 2017.

AVELAR, Alexandre de Sá. Rumo à indisciplinarização? Tempo histórico e a historiografia recente sobre o período militar. Disponível em: https://www.academia.edu/19973700/Rumo_\%C3\%A0_ indisciplinariza\%C3\%A7\%C3\%A30_Tempo_hist\%C3\%B3rico_e_a_ historiografia_recente_sobre_o_per\%C3\%ADodo_militar. Acesso em: 19 mar. 2017.

FICO, Carlos. Vídeo-palestra sobre Comissão da Verdade. Disponível em: http://www.brasilrecente.com/2011/11/videopalestra-sobre-comissaoda-verdade_19.html. Acesso em: 19 mar. 2017.

GINZBURG, Carlo. El juez y el historiador: consideraciones al margen del proceso Sofri. Madrid: Anaya, 1993.

HABERMAS, Jürgen. A constelação pós-nacional: ensaios políticos. São Paulo: Littera, 2001.

MOTTA, Rodrigo Patto Sá. Os lugares dos historiadores e da história na sociedade brasileira: Conferência de abertura do XXVIII Simpósio Nacional de História, Florianópolis. História da Historiografia, n. 22, p. 321-335, 2016.

PEREIRA, Mateus Henrique de Faria. Nova direita? Guerras de memória em tempos de Comissão da Verdade (2012-2014). Varia História, v. 31, n. 57, p. 863-902, 2015.

ROUSSO, Henry. La hantise du passé. Paris: Textuel, 1998. 


\section{Pareceristas deste número reviewers of this issue}




\section{Pareceristas deste número}

Adriane Vidal Costa (UFMG)

Claudia Wasserman (UFRGS)

Cláudio Pereira Elmir (UNISINOS)

Clifford Andrew Welch (UNIFESP)

Enidelce Bertin (Uninove)

Flávio Francisco (Unesp)

Gonzalo Pasamar (Universidad de Zaragoza - Espanha)

Jailsson Pereira da Silva (UFC)

Juan Manuel Perez (Universidad de Las Palmas de Gran Canaria - Espanha)

Julio Bentivoglio (UFES)

Maria Eugenia Gay (Universidad Nacional de Quilmes - Argentina)

Marieta de Moraes Ferreira (CPDOC/FGV)

Mateus Henrique Pereira (UFOP)

Nicolás Lavagnino (Universidad de Buenos Aires - Argentina)

Nilson Fraga (UEL)

Nuno de Pinho Falcão (Universidade do Porto - Portugal)

Renata Figueiredo Moraes (UERJ)

Valeria Castelló-Joubert (Universidad de Buenos Aires - Argentina) 


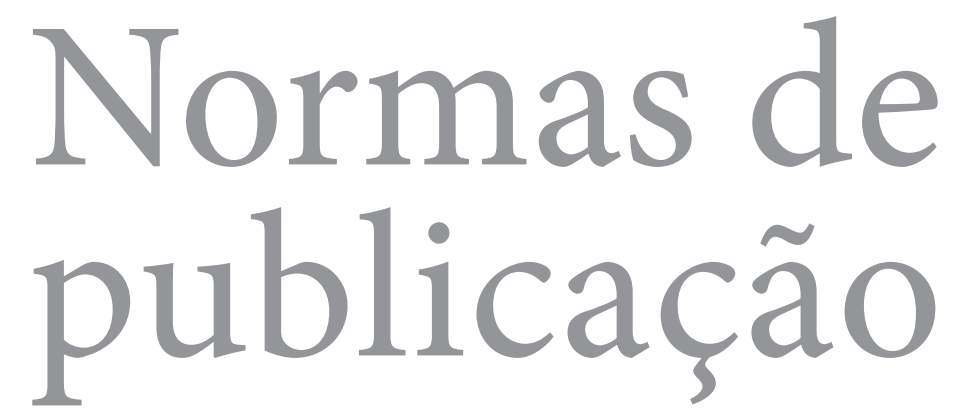

editorial guidelines 
1) As colaborações poderão ser feitas sob as seguintes formas:

1.1. Artigo inédito e original (entre 28.000 e 54.000 caracteres com espaço, incluindo as notas e as referências bibliográficas).

1.2. Resenha de livro (máximo de 18.000 caracteres com espaço). As resenhas devem ter título, seguido pela referência bibliográfica completa da obra. Caso seja necessário, a bibliografia deve vir ao final da resenha, e as notas devem seguir os padrões editoriais da revista. Recomenda-se que as resenhas de livro escrito por um só autor apresentem uma avaliação crítica do trabalho à luz da literatura previamente existente sobre o tema.

1.3. Textos e documentos historiográficos. Os documentos devem ser antecedidos por um pequeno texto de apresentação, escrito pelo autor da submissão. $O$ conjunto (apresentação + documento) não deve ultrapassar os 80.000 caracteres com espaço. Recomenda-se entrar em contato com os editores antes de preparar a submissão.

1.4. Entrevistas. Devem contar com um texto introdutório acerca do entrevistado. O conjunto (apresentação + entrevista) deve conter de 27.000 a 54.000 caracteres com espaços. Recomenda-se entrar em contato com os editores antes de preparar a submissão.

2) A revista aceita três tipos de resenha:

2.1. Resenha resumo: texto que se limita a resumir ou descrever o conteúdo de um livro, sem qualquer crítica ou julgamento de valor, sem a preocupação de relacionar a obra resenhada a outras do mesmo gênero. Objetivo principal é 179 informar o leitor e divulgar a obra.

2.2. Resenha crítica: além de resumir a obra, faz uma avaliação da mesma, apontando aspectos positivos e negativos, além de procurar situá-la em relação a outras do gênero ou que tratam do mesmo tema. Trata-se de um texto de opinião, também conhecido como recensão crítica. $O$ objetivo da resenha crítica não é apenas informar o leitor sobre a obra, mas guiar o leitor no conjunto da produção historiográfica sobre um dado assunto, indicando parâmetros para o estudo de um tema, ao situar a obra em relação aos estudos e apontar suas contribuições e lacunas. Exige que o resenhista tenha conhecimentos da área e erudição suficiente para poder situar a obra em um contexto de estudos.

2.3. Resenha temática: trata de vários textos que tenham um assunto comum; é uma espécie de balanço bibliográfico sobre um tema. Tem caráter necessariamente crítico, pois demanda análise e opinião sobre os estudos tratados. Assim como no caso da resenha crítica de uma obra, a resenha temática também tem por objetivo guiar os leitores no conjunto dos estudos sobre um dado tema.

3) Os artigos devem conter, no início, resumo (de 700 a 1.050 caracteres com espaço) e três palavras-chave, ambos seguidos de traduções para língua inglesa.

4) Recomenda-se que os autores dividam os artigos em seções, que devem consistir em títulos explicativos, em negrito e com maiúscula apenas no início 
(ou, se nele houver, substantivo próprio). Em hipótese alguma será aceita a divisão de seções por algarismo.

5) Serão aceitas resenhas de livros que tenham sido publicados, no máximo, há três anos ou então títulos há muito esgotados e com reedição recente. Recebemos, excepcionalmente, resenhas de obras publicadas em anos anteriores, desde que haja justificativa, considerando a relevância do livro e a atualidade das questões que aborda.

6) A contribuição deve ser original e inédita, não estar sendo avaliada por outra publicação e não ter indicação de autoria. Os autores devem excluir todas as informações do arquivo que possam identificá-los como tal.

7) Quando houver financiamento da pesquisa, o autor deve indicar, em nota de rodapé ligada ao título da contribuição, a instituição financiadora.

8) As resenhas, os textos e documentos historiográficos e as entrevistas deverão conter três palavras-chave em português e em inglês, assim como os respectivos títulos nos dois idiomas.

9) As citações em língua estrangeira devem ser traduzidas. O original constará em nota de rodapé, com a informação sobre a autoria da tradução.

10) Todos os artigos, inclusive os submetidos para publicação em dossiê, serão analisados por, pelo menos, dois membros do Conselho Consultivo ou assessores ad hoc, que podem, mediante consideração da temática abordada, seu tratamento, clareza da redação e concordância com as normas da revista, recusar a publicação ou sugerir modificações. Os pareceres têm caráter sigiloso. Ao Conselho Editorial fica reservado o direito de publicar ou não os textos enviados de acordo com a pertinência em relação à programação dos temas da revista.

11) Os artigos, resenhas, entrevistas e textos e documentos historiográficos passarão por uma pré-seleção do Conselho Editorial que avaliará sua pertinência com relação à temática do periódico. Uma vez aprovados na pré-seleção, serão encaminhados para pareceristas.

12) As resenhas, entrevistas, e textos e documentos historiográficos serão avaliados por um membro do Conselho Editorial ou Consultivo, que levará em conta os critérios depertinência temática do material apresentado com relação à linha editorial do periódico e a qualidade e consistência do texto da resenha, entrevista ou texto e documento historiográfico.

13) As palavras-chave devem ser preferencialmente retiradas do banco de palavras-chave elaborado pelos editores da revista. Caso o autor considere recomendável inserir uma palavra-chave que não esteja contida no referido 
banco, deve expressamente pedir sua inclusão no sistema de busca. A solicitação será avaliada pelos editores.

14) As colaborações devem ser enviadas em Times New Roman, corpo 12, espaçamento 1,5 e com margens de $3 \mathrm{~cm}$. As citações com mais de três linhas devem ser destacadas do texto, sem aspas, compondo parágrafo com recuo, à direita, de 1,5 cm, corpo 11 e espaçamento simples.

15) Todos os textos deverão ser apresentados após revisão ortográfica e gramatical. A revista publica contribuições em português, espanhol, inglês, francês e italiano.

16) As notas de rodapé devem ser apenas de caráter explicativo. As referências devem vir em corpo de texto tendo o seguinte formato:

(ABREU 2005, p. 36).

17) A referência à textos clássicos também deve ser feita no corpo do texto, com indicações do nome do autor, da primeira palavra do título da obra (em itálico) e da seção e/ou as linhas citadas, tal como nos seguintes exemplos: Aristóteles, Poética VII; Tucídides, História IV, 49. A referência completa à obra citada deve aparecer ao final do texto, na lista da bibliografia utilizada.

18) As referências bibliográficas, listadas em ordem alfabética, devem estar no final do texto e seguirem os modelos abaixo:

Livro

KOSELLECK, Reinhart. Futuro passado: contribuição à semântica dos tempos históricos. Rio de Janeiro: Contraponto; Editora PUC-Rio, 2006.

Capítulo de livro

CASSIRER, Ernst. A linguagem. Introdução e exposição do problema. In:

A filosofia das formas simbólicas. São Paulo: Martins Fontes, 2001, p. 9-74.

Coletânea

CARDOSO, Ciro Flamarion; MALERBA, Jurandir (Org.). Representações: contribuições a um debate transdisciplinar. Campinas: Papirus, 2000.

Artigos em periódico

RIGOLOT, François. The Renaissance Crisis of Exemplarity. Journal of the History of Ideas, v. 59, n. 4, p. 557-563, 1998.

Texto disponível na internet

HEGEL, Georg W. F. Filosofia da História. 2. ed. Brasília: Editora UnB, 1995. Disponível em: http://gutenberg.spiegel.de/buch/1657/1. Acesso em: 20 set. 2013. 
Trabalho publicado em anais eletrônicos

ARAÚjO, Rodrigo Cardoso Soares de. O polêmico Corsário, um pasquim da Corte Imperial (1880-1883). In: SEMINÁRIO DIMENSÕES DA POLÍTICA NA HISTÓRIA: ESTADO, NAÇÃO, IMPÉRIO, I, 2007, Juiz de Fora. Anais... Juiz de Fora: Clio Edições, 2007, p. 500-501.

Tese acadêmica

RIBEIRO, Tatiana O. A apódexis herodotiana: um modo de dizer o passado. Tese (Doutorado em Letras Clássicas) - Programa de Pós-Graduação em Letras Clássicas, Universidade Federal do Rio de Janeiro, Rio de Janeiro, 2010.

Artigo de jornal GLEISER, Marcelo. Newton, Einstein e Deus. Folha de S. Paulo, 13 jun. 2010. Ilustrada, p. A23.

Pede-se os autores que indiquem, nas referências bibliográficas, a primeira edição de livros com várias reedições, seguindo o padrão: CROCE, Benedetto. Teoria e storia della storiografia. Bari: Laterza, 1973 [1913].

19) Desde o seu terceiro número, a revista História da Historiografia adotou a nova ortografia estabelecida no Novo Acordo Ortográfico da Língua Portuguesa. Recomenda-se aos colaboradores a adoção da nova ortografia nos materiais 182 enviados para avaliação e publicação na revista.

20) O envio de manuscritos implica a cessão de direitos autorais e de publicação à História da Historiografia, que não se compromete com a devolução das colaborações recebidas. Os textos publicados na revista não podem ser republicados em outros meios e/ou formatos sem a autorização expressa dos editores. Os dados, conceitos e opiniões apresentados nos trabalhos, bem como a exatidão das referências documentais e bibliográficas, são de inteira responsabilidade dos autores.

21) Todas as colaborações devem ser enviadas exclusivamente pelo site da revista: http://www.historiadahistoriografia.com.br. 


\section{Diretrizes para autores}

guidelines for authors 
1) Sugestões para a elaboração de resumo:

O resumo é um breve sumário do artigo. Ele não deve ser uma introdução do texto, mas uma descrição completa e sintética do conteúdo do artigo, indicando os objetivos e os aspectos centrais do argumento, a forma de abordagem do tema e as conclusões e/ou hipóteses do estudo. As informações devem ser expostas em um parágrafo, com narrativa contendo introdução (tema central do estudo e objetivos), meio (forma de abordagem do tema e fontes utilizadas) e fim (conclusões ou hipóteses principais).

\subsection{Detalhamento das partes do resumo:}

Introdução: a parte inicial do resumo deve fornecer uma introdução ao tema ou problema do estudo. Ela deve identificar a questão central do trabalho. É preciso dizer em poucas palavras sobre o que é o artigo. A introdução deve ser seguida pelos objetivos (gerais e específicos) do estudo, sendo possível eliminar a introdução e expor os objetivos no início de forma mais direta.

Meio: apresenta de forma clara as questões, os objetivos, os argumentos centrais e a forma de abordagem do tema.

Fim: indica a conclusão principal do estudo ou a hipótese (quando houver).

\subsection{O resumo deve poder responder às seguintes questões:}

Do que o texto trata?

Quais os objetivos?

Como o estudo foi conduzido?

Quais foram os resultados ou as conclusões da pesquisa?

Lembramos aos autores que o resumo é o primeiro contato do leitor com o estudo e pode ser o único elemento recuperado nas bases de dados científicos sobre um determinado tema. Além disso, se o resumo for bem escrito poderá auxiliar os avaliadores do artigo, esclarecendo possíveis dúvidas sobre os objetivos e conclusões do autor. Também poderá atrair leitores para o texto.

2) Sobre as palavras-chave

As palavras-chave devem comunicar os conceitos e/ou categoriais centrais do estudo. A seleção criteriosa das palavras-chave facilitará a recuperação das pesquisas, uma vez que tais palavras são utilizadas na indexação e busca de estudos nas bases de dados científicos. 